$$
\text { UNIVERSIDADE DE SÃO PAULO }
$$

FACULDADE DE FILOSOFIA, LETRAS E CIÊNCIAS HUMANAS DEPARTAMENTO DE GEOGRAFIA PROGRAMA DE PÓS-GRADUAÇÃO EM GEOGRAFIA FÍSICA

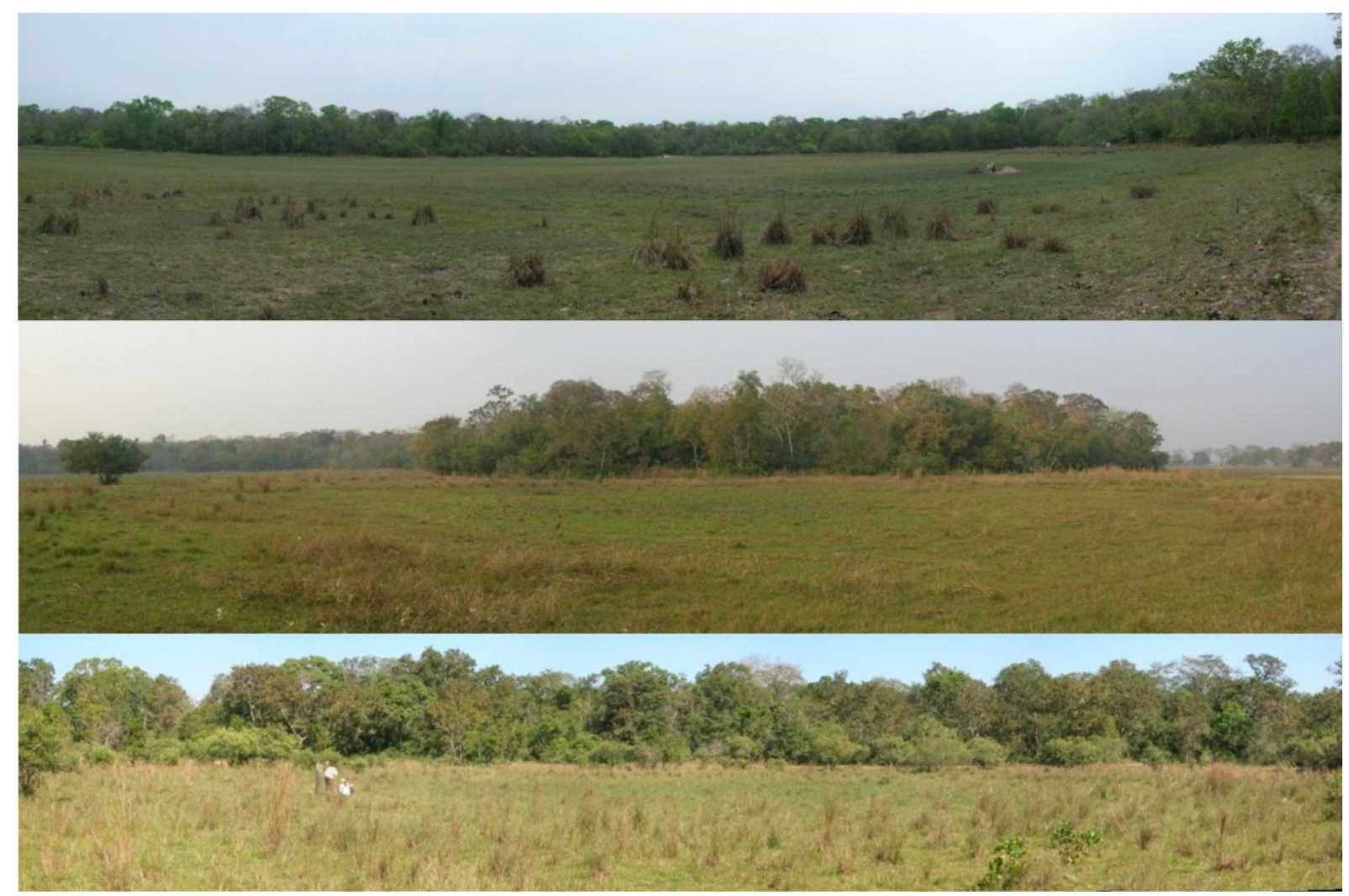

ESTUDO MORFOLÓGICO E HIDROQUÍMICO DE PEQUENAS DEPRESSÕES NA NHECOLÂNDIA, PANTANAL, MS.

TATIANA MASCARI PARIZOTTO 
TATIANA MASCARI PARIZOTTO

\section{ESTUDO MORFOLÓGICO E HIDROQUÍMICO DE PEQUENAS DEPRESSÕES NA NHECOLÂNDIA, \\ PANTANAL, MS.}

Dissertação apresentada ao Programa de PósGraduação em Geografia Física da Faculdade de Filosofia, Letras e Ciências Humanas da Universidade de São Paulo, para a obtenção do título de Mestre em Ciências.

Área de concentração: Geografia

Orientador: Prof ${ }^{a}$ Dr ${ }^{a}$ Sônia Maria Furian

São Paulo

2012 
Autorizo a reprodução e divulgação total ou parcial deste trabalho, por qualquer meio convencional ou eletrônico, para fins de estudo e pesquisa, desde que citada a fonte.

Catalogação na Publicação

Serviço de Biblioteca e Documentação

Faculdade de Filosofia, Letras e Ciências Humanas da Universidade de São Paulo

Parizotto, Tatiana Mascari

Estudo morfológico e hidroquímico de pequenas depressões na Nhecolândia, Pantanal, MS. / Tatiana Mascari Parizotto; orientadora Sônia Maria Furian. São Paulo, 2012.

$111 \mathrm{f}$.

Dissertação (Mestrado) - Faculdade de Filosofia, Letras e Ciências Humanas da Universidade de São Paulo. Departamento de Geografia. Área de concentração: Geografia Física.

1. Morfologia do solo. 2. Funcionamento hídrico. 3. Condutividade elétrica aparente. 4. Pantanal da Nhecolândia. 5. Redistribuição do ferro. I. Furian, Sônia Maria, orient. II. Título. 
Dedico este trabalho aos meus queridos pais, que mesmo longe me deram força, apoio e amor para continuar. 


\section{AGRADECIMENTOS}

A Prof ${ }^{a}$ Dra ${ }^{a}$ Sônia Maria Furian por orientar este trabalho, aplicar seus conhecimentos nesta pesquisa e pelas horas agradáveis que passamos.

Ao Prof. Dr. Laurent Barbiéro, IRD; LMTG, Université de Toulouse, France; CENA/USP - Piracicaba, pela co-orientação deste trabalho, e auxílio nos trabalhos de campo.

A banca de qualificação: Prof ${ }^{a}$ Dra ${ }^{-}$Rosely Pacheco Dias Ferreira, e o Prof. Dr. Carlos Roberto Espindola pelas importantes contribuições ao desenvolvimento desta pesquisa.

A Moreli Teixeira Arantes, proprietária da Fazenda Centenário (Aquidauana/MS), pelo apoio à pesquisa e livre acesso a sua fazenda.

Ao Paul Michael Grol por nos ceder um alojamento na Fazenda Embiara, sem o qual não seria possível realizar este trabalho.

Ao Prof. Dr. Reynaldo Luis Victoria pela logística de campo e laboratório, e apoio ao Projeto FAPESP N²008/09086-7, projeto no qual o trabalho se desenvolveu.

À USP pela oportunidade em se fazer pesquisa de qualidade.

Aos funcionários da Secretária de Graduação de Geografia - USP, pelas informações e materiais concedidos.

À UFMS pela disponibilização de veículos para a realização dos trabalhos de campo no Pantanal.

Ao Prof. Ary Tavares Rezende Filho pela ajuda nas coletas de dados nos campos realizados no Pantanal.

Ao Prof. Dr. Francisco Yukio Hiodo pela disponibilidade e ajuda nos procedimentos analíticos realizados no Laboratório de Geofísica Aplicada, Departamento de Geofísica - IAG/USP.

Ao Prof. Dr. Vagner Roberto Elis do Departamento de Geofísica - IAG/USP por fornecer informações importantes a este trabalho.

Ao Prof. Dr. Paulo César Fonseca Giannini responsável pelo Laboratório de Sedimentologia, do Instituto de Geociências/USP, e à Elaine Aparecida da Silva Sinfrônio, pelo auxílio nos procedimentos analíticos.

Ao Prof. Dr. Daniel Atêncio responsável pelo Laboratório de Difração de Raio-X, do Instituto de Geociências/USP, onde foram realizadas as análises de difratometria, e ao técnico Dr. Flávio Machado de Souza Carvalho pelo auxílio. 
À FAPESP, pela bolsa concedida e com isto me dedicar exclusivamente à pesquisa. Ao Laboratório de Pedologia, e toda a equipe, pelo apoio à pesquisa, e empréstimos de materiais e equipamentos.

À COSEAS por disponibilizar uma vaga no Conjunto Residencial da USP.

Ao Joelson J. Gonçalves Teodoreto por todo o apoio logístico no Pantanal e pela companhia.

Ao meu irmão Vinicíus Mascari Parizotto, por cuidar dos meus pais neste tempo longe de casa.

À Elisângela Rosemeri Martins Silva pela amizade, força e apoio na conclusão deste trabalho, assim como nos trabalhos de campo.

Aos meus amigos Flávia Ré, Núbia Esteban e Marcos Pinheiro, pela amizade e apoio nas horas difíceis.

Em especial, ao Gustavo Pereira, pelo apoio, paciência, dedicação e amor, indispensáveis ao desenvolvimento e término desta pesquisa. 


\section{RESUMO}

A porção sul do Leque Aluvial do Taquari, chamada Nhecolândia, é uma sub-região do Pantanal Mato-Grossense, que apresenta um complexo sistema de lagoas arredondadas, vazantes, cordilheiras, corixos e "pequenas depressões". Estudos anteriores mostraram que os fluxos de águas subsuperficiais dependem da intensidade das cheias, e da presença e forma dos horizontes verdes argilosos, localmente cimentados, que limitam fortemente a permeabilidade, e comandam os fluxos laterais. Inicialmente associados a ambientes alcalinos das salinas, esses horizontes também ocorrem em ambientes diluídos, como as pequenas depressões. O objetivo geral deste trabalho é compreender o funcionamento hídrico de três pequenas depressões, em relação com as características morfológicas dos solos. Métodos de indução eletromagnética foram utilizados para mapear a condutividade elétrica aparente (CEa); complementados por métodos de descrições das características morfológicas dos solos, e de análises granulométricas e mineralógicas em laboratório. Estes trabalhos foram complementados por análises físico-químicas das águas nas depressões; e pelo monitoramento do nível do lençol freático entre uma depressão e uma baía. O horizonte verde argiloso, mais ou menos endurecido, aparece na base das sequências de solos nas três pequenas depressões, ao qual se superpõem horizontes arenosos superficiais e subsuperficiais. As principais diferenciações morfológicas observadas referem-se aos processos de redistribuição de ferro e da matéria orgânica, ligados ao regime hídrico. No período seco, quando ocorre um rebaixamento do nível freático, o horizonte verde argiloso funciona como uma soleira e fragmenta o lençol, que passa a funcionar como dois segmentos, um ligado à Depressão Fechada, e outro à Baía. Ao longo do ano, a Depressão Fechada acumula água apenas temporária e fugazmente. Na maior parte do tempo, ela funciona como área dispersora de água às unidades morfológicas adjacentes, salientando sua importância funcional na Nhecolândia.

Palavras chaves: Pequenas Depressões; Condutividade Elétrica aparente; Morfologia dos Solos; Redistribuição do Ferro; Funcionamento Hídrico; Lençol Freático; Pantanal. 


\begin{abstract}
The southern part of the Taquari alluvial fan, called Nhecolândia, is a sub-region of the Pantanal of Mato-Grosso exhibiting a complex of round shape lakes, draining fields, forested sandy areas, small watercourses and "small depressions". Former studies have shown that the sub-superficial water fluxes depend on the intensity of the flood and on the presence and shape of a sandy clay loam greenish horizon, locally cemented, which acts as an impervious layer and drives lateral fluxes. Although its presence has always been associated to the alkaline-saline parts of this singular landscape, it also occurs below small freshwater depressions. The objective of this study is to understand the hydrological functioning of these small depressions in relation to the soil cover layout. Electromagnetic induction methods were used to draw apparent electrical conductivity (CEa) maps, crossed with direct auger holes and pits observations, and laboratory analysis (grain size distribution and mineralogy). Physico-chemical analysis of the ground water in the depressions and a monitoring of the groundwater fluctuation along one year were also performed.

The greenish horizon, more or less cemented, occurred at the base of the soil system in all the studied depressions. It was overlaid by more sandy horizons. The main pedological differentiation was organic matter and iron redistribution along the soil sequences, in relation with the hydrological regime. During the dry season, the watertable goes down and the greenish horizon acts as a threshold, disconnecting various watertables in the different parts of the landscape. Along the year, the closed depressions accumulate the water only temporarily and fleetingly. Most of the time, they work as areas of water redistribution towards the surrounding landscape units, and therefore have a essential function in the Nhecolândia.
\end{abstract}

Keywords: Small Depressions; Apparent Electrical Conductivity; Soil Morphology; Iron Redistribution; Hydrological Functioning; Watertable; Pantanal Wetland. 


\section{LISTA DE FIGURAS}

Figura 1 Bacia do Alto Paraguai e seus grandes compartimentos geomorfológicos (Alvarenga et al.,1984)....

Figura 2 Leques aluviais do Pantanal: 1 - Corixo Grande; 2 Cuiabá; 3 - São Lourenço; 4 - Taquari; 5 - Taboco; 6 Aquidauana, e 7 - Nabileque (Mosaico Landsat 4/5 GeoCover 1990, composição R7G4B2, Zani, 2008).

Figura $3 \quad$ Carta dos solos do Pantanal (RadamBrasil, 1982).................

Figura 4 As sub-regiões do Pantanal (Silva e Abdon, 1998)................. 14

Figura 5 Feições morfológicas da Nhecolândia (Barbiero et al.,2002).

Figura 6 1) $\mathrm{Na}$ época da cheia as lagoas se conectam pela subida do nível do lençol freático; 2) ao contrário, na época da seca o nível do lençol abaixa e a conexão se interrompe, pois os horizontes pouco permeáveis passam a funcionar como soleiras. Consequentemente, passa a existir dois níveis de lençol, e as águas das salinas tendem a evaporar-se e a concentrar sais (Barbiero et al.; 2008).

Figura 7 Mapas de solos da Nhecolândia: (A) Cunha, 1981; (B) ANA, 2003; (C) EMBRAPA - PCBAP, 1997; (D) IBGE, 2001; (E) RadamBrasil,1982.

Figura 8 Localização da área de estudo ao sul da Nhecolândia............

Figura 9 Localização das três pequenas depressões estudadas..........

Figura 10 Posicionamento da Depressão Aberta 1 no braço final da Vazante Castelo.

Figura 11 Depressão Aberta 2. O traço pontilhado em branco salienta a pequena elevação do terreno que separa as duas depressões (DA1 e DA2).

Figura 12 Depressão Fechada circundada por cordilheira.

Figura 13 Curvas de respostas teóricas dos aparelhos (A) EM31 e (B) EM38 (Geonics).

Figura 14 Modelo de aparelho para medir a resistividade do solo (AbuHassanein et al.,1996). 
Figura 15 (A) Localização da Depressão Fechada (Google Earth, 2010) e (B) a sequência de solos.

Figura 16 (A) Localização das sequências de solos: (1) na Depressão Aberta 1; (2) na Depressão Aberta 2; (3) entre as Depressões Abertas 1 e 2 .

Figura 17 Localização: (a) Piezômetros: (P1) na Baía, (P2) no centro da Depressão Fechada; (b) dos coletores de água do lençol: (G1) ao (G6).

Figura 18 Mapa com a distribuição das principais unidades de paisagem em uma porção ao sul da Nhecolândia.

Figura 19 Perfis topográficos: $(A)$ do braço terminal da vazante; $(B)$ da Depressão Aberta 1; (C) da Depressão Aberta 2; (D) da Depressão Fechada.

Figura 20 Mapas topográficos das pequenas depressões: (E) Depressão Aberta 1, (F) Depressão Aberta 2 e (G) Depressão Fechada.

Figura 21 Correlação dos valores de CEa (aparelho EM38 x PCLoop) na Depressão Aberta 2 (DA2) e na Depressão Fechada (DF)

Figura 22 Semivariogramas e respectivas interpolações espaciais dos valores da CEa na Depressão Aberta 2: (A) EM31 V; (B) EM31 H; (C) EM38 V. O pontilhado em azul indica os pontos de medidas.

Figura 23 Semivariogramas e respectivas interpolações espaciais dos valores de CEa na Depressão Fechada: (D) EM38 H; (E) EM38 V; (F) EM31 V. O pontilhado em azul indica os pontos de medidas.

Figura 24 Sequência de solos da Depressão Aberta 1 e sua localização na vazante.

Figura 25 Sequência de solos na Depressão Aberta 2.

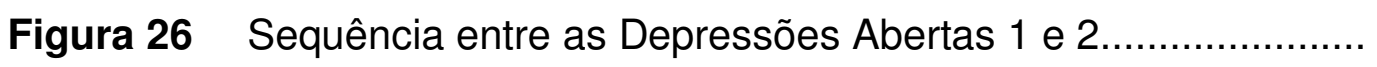

Figura 27 Sequência de solos na Depressão Fechada.

Figura 28 (A) Localização e (B) delimitação do horizonte amarelo arenoso no centro da Depressão Fechada $(\mathrm{t} 1$ = pontos de tradagens) 
Figura 29 Localizações das amostras de solos coletadas para a granulometria na trincheira da Depressão Aberta 1, localizada no centro da depressão.

Figura 30 Localização das coletas de amostras de solos para análise granulométrica na Depressão Aberta 2

Figura 31 Enquadramento dos horizontes nas classes texturais pelas porcentagens de areia, silte e argila (segundo triângulo textural apresentado por Lemos e Santos, 1992).

Figura 32 Localização dos coletores na Depressão Fechada (G1 a G6).

Figura 33 Gráfico de monitoramento do nível do lençol freático entre a Depressão Fechada e uma Baía situada a SE.

Figura 34 Mapa de distribuição da CEa na Depressão Aberta 2. A seta mostra a direção NE-SW destacada pelos maiores valores de CEa.

Figura 35 Diagrama Eh-pH do ferro (simplificado de Pourbaix).

Figura 36 Desenho representativo do processo de redistribuição de ferro na Depressão Fechada.

Figura 37 Foto da trincheira localizada no centro da Depressão Aberta 1. As setas brancas mostram a interdigitação dos horizontes (2) e (3), e manchas brancas de areia lavada no horizonte (3). As setas vermelhas indicam a migração da matéria orgânica, em veios, e do ferro do horizonte (3) para o (4).....

Figura 38 Identificações dos horizontes na trincheira da Depressão Aberta 1

Figura 39 Localização da soleira na Depressão Fechada: pontos (GA) e (GB) elevações do horizonte (6) verde argiloso, localizado por tradagens. Este esquema se baseia no nível freático do dia 3/11/10 (Gráfico, Figura 32).

Figura 40 (A) Primeira situação: invasão das águas superficiais da vazante na Baía, e fluxos das águas do lençol da Baía em direção à Depressão Fechada; (B) Segunda situação: desconexão com as águas superficiais da vazante e fluxos de águas subsuperficiais da Depressão Fechada em direção à Baía. 
Figura 41 Nível do lençol freático mais alto na Baía, fluxos subsuperficiais em direção à Depressão Fechada e fluxos de saída das águas da depressão

Figura 42 Fotos que ilustram as Depressões Abertas secas e/ou cheias d'água nas respectivas datas de campo................... 


\section{LISTA DE TABELAS}

Tabela 1 Relação das amostras de solos das três pequenas depressões e suas respectivas análises.................................

Tabela 2 Intervalos de tamanhos de partículas

Tabela 3 Valores de resistividade dos horizontes identificados na Depressão Fechada (DF) e Depressão Aberta 2 (DA2)

Tabela 4 Dados da análise granulométrica da Depressão Aberta

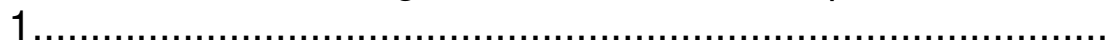

Tabela 5 Dados da análise granulométrica da Depressão Aberta 2 ...

Tabela 6 Resultados da análise granulométrica dos horizontes da Depressão Fechada.

Tabela 7 Resultados das medidas in situ das variáveis físicoquímicas de águas superficiais e subsuperficiais das Depressões Abertas 1 e 2, Depressão Fechada e Baía. 


\section{LISTA DE FOTOS}

Foto 1 Aparelhos: (A) EM31-MK2 e (B) EM38-MK2

Foto 2 Aparelho utilizado no laboratório para medir a resistividade do solo

Foto 3 (A) Amostras de solos com água oxigenada sobre uma placa aquecida para remoção de MO. Detalhe das amostras em efervescência após acrescentar água oxigenada (B) e (C)

Foto $4 \quad$ (A) Pipetagem; (B) Peneiramento

Foto 5 (A) Sondas tipo Mini Diver $\AA$; (B) piezômetro instalado no centro da Depressão Fechada; (C) e na Baía no limite capim rabo-de-burro - água

Foto 6 (A) Coletor de água; (B) e (C) coleta de água do lençol com o auxilio da bomba de sucção.

Foto 7 Horizonte (1c) amarelo arenoso localizado no centro da Depressão Fechada.

Foto 8 Horizonte (7) argiloso com manchas avermelhadas localizado na Depressão Aberta 2. 


\section{SUMÁRIO}

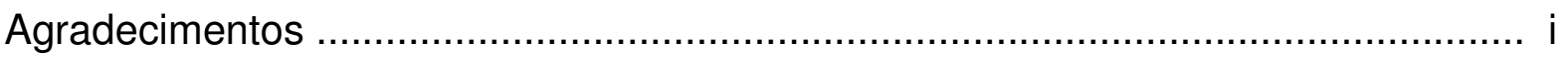

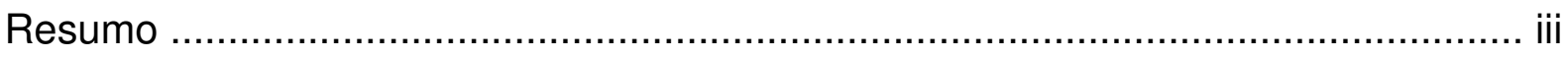

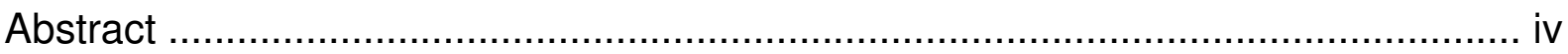

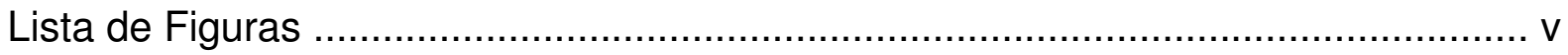

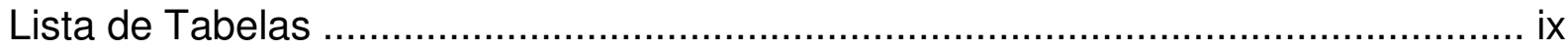

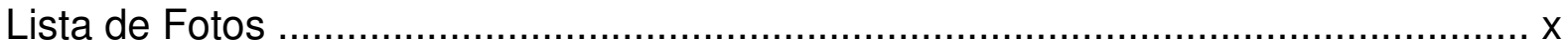

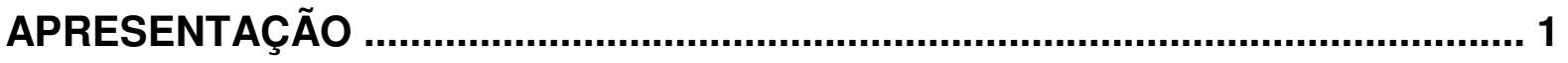

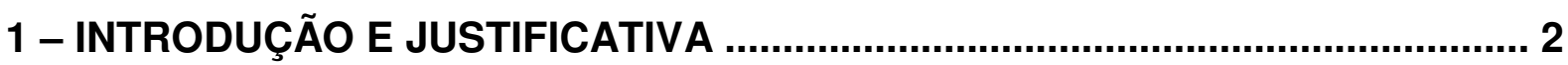

2 - QUADRO GERAL

2.1 - O PANTANAL MATO-GROSSENSE ................................................... 5

A) Geologia e geomorfologia ...................................................................... 5

B) Hidrologia e química das águas .......................................................... 10

C) Clima, vegetação e tipos de solos ...................................................... 11

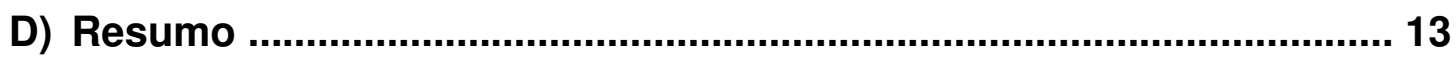

2.2 - A NHECOLÂNDIA............................................................................. 14

A) Feições morfológicas e topografia .................................................. 15

B) Sistema de drenagem ........................................................................... 16

C) Solos, processos geoquímicos e pedológicos .................................. 18

D) Resumo ........................................................................................ 21

2.3 - OBJETIVOS ESPECÍFICOS ............................................................... 21

3 - MATERIAIS E MÉTODOS

3.1 - MATERIAIS ............................................................................................ 22

A) Depressões Abertas 1 (DA1) e 2 (DA2) ......................................... 23

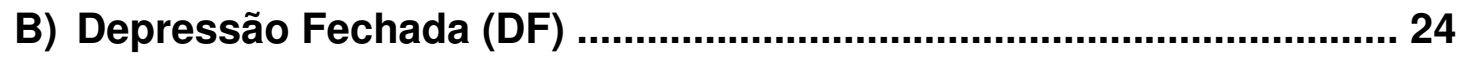

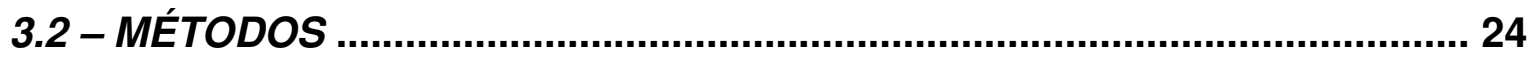

A) Confecção do mapa fisiográfico ....................................................... 25

B) Morfologia dos solos ...................................................................... 26 
I-Métodos indiretos

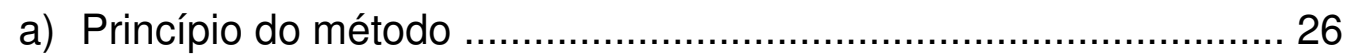

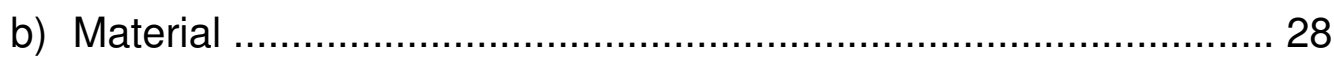

c) Aquisição e tratamento dos dados ............................................... 29

d) Testes e qualidade dos dados ................................................... 30

II - Métodos diretos

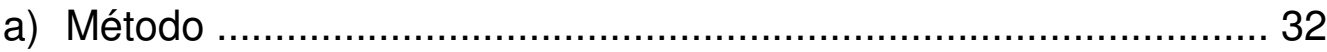

b) Localização das sequências .................................................. 33

C) Caracterização dos constituintes sólidos ......................................... 35

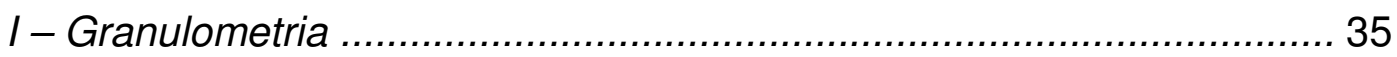

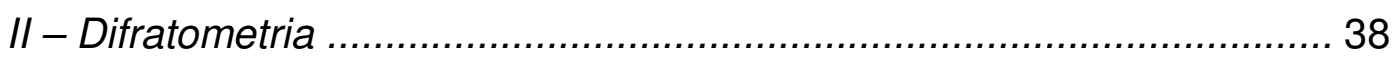

D) Monitoramento e características das águas ...................................... 39

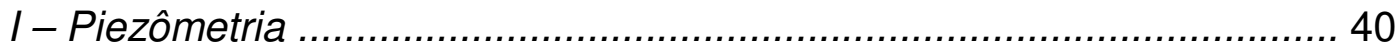

II - Coletores de água do lençol freático ............................................... 42

4 - RESULTADOS

\section{1 - MAPA FISIOGRÁFICO}

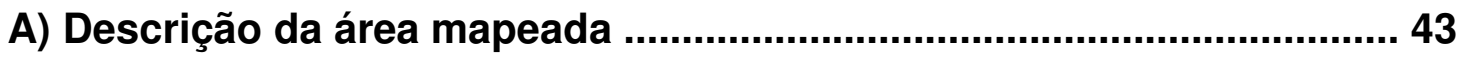

B) Unidade "pequenas depressões" ..................................................... 45

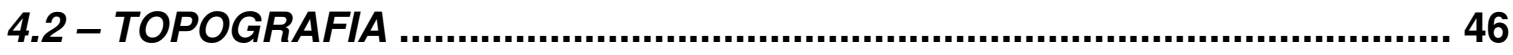

4.3 - VALIDAÇÃO DOS DADOS DE CONDUTIVIDADE ELÉTRICA

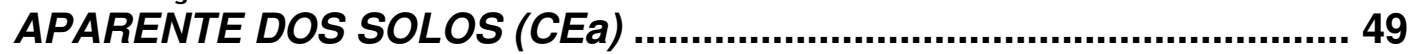

4.4 - SEMIVARIOGRAMA E MAPA DA CONDUTIVIDADE ELÉTRICA

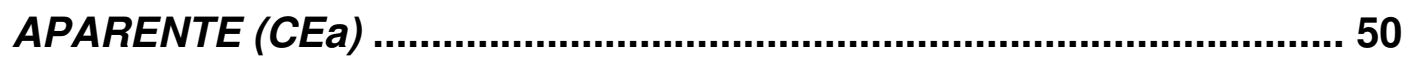

4.5 - CARACTERÍSTICAS DO SISTEMA PEDOLÓGICO

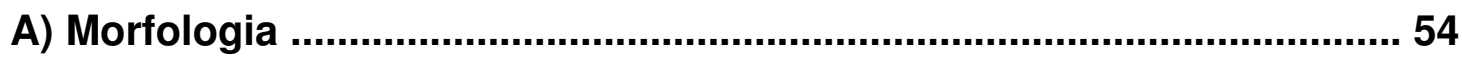

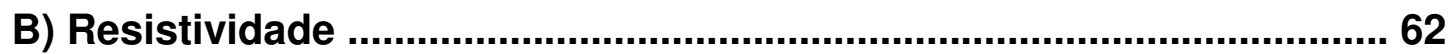

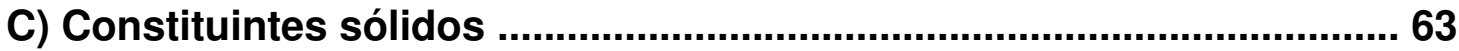

4.6 - CARACTERÍSTICAS FÍSICO-QUÍMICAS DAS ÁGUAS ........................ 68

4.7 - MONITORAMENTO DO NÍVEL DA ÁGUA DO LENÇOL FREÁTICO ENTRE A DEPRESSÃO FECHADA E A BAÍA. 


\section{5 - DISCUSSÕES DOS RESULTADOS}

\section{1 - METODOLOGIA}

A) Validação dos dados do EM38

B) Validação dos mapeamentos de CEa e localização dos pontos de medidas.

5.2 - MAPA FISIOGRÁFICO

5.3 - MORFOLOGIA DOS SOLOS NAS PEQUENAS DEPRESSÕES

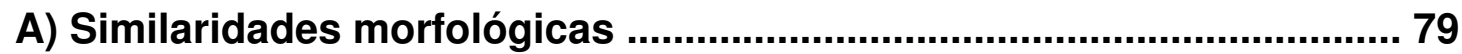

B) Similaridades de contituintes ......................................................... 79

C) Diferenciações pedológicas dos horizontes ...................................... 80

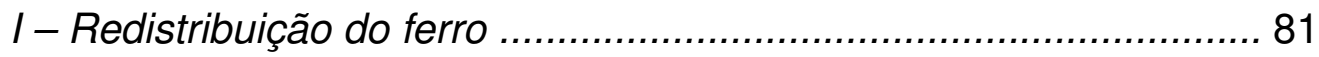

II - Dinâmica da matéria orgânica .................................................... 84

III - Variações no solo não relacionadas às diferenciações

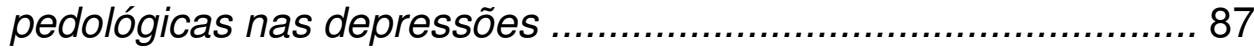

D) CEa, morfologia e resistividade dos solos .......................................... 88

\section{4 - DINÂMICA DAS ÁGUAS NAS DEPRESSÕES}

A) Monitoramento do nível freático na Depressão Fechada e na Baía

I - Soleira hidríca 89

II - Funcionamento hídrico da Depressão Fechada durante uma cheia Excepcional .....

B) Dinâmica das águas nas Depressões Abertas

96

6 - CONSIDERAÇÕES FINAIS

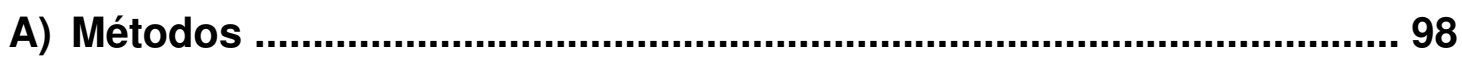

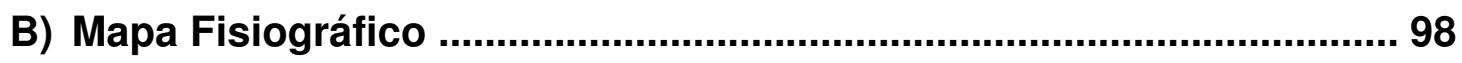

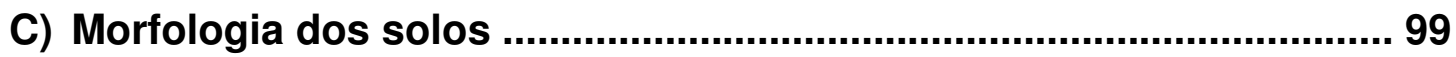

D) Funcionamento hídrico da Depressão Fechada ................................ 100

7 - BIBLIOGRAFIA

ANEXOS 


\section{APRESENTAÇÃO}

O objetivo desta dissertação foi estudar uma das unidades morfológicas comuns na Nhecolândia, as pequenas depressões. Partiu-se do pressuposto que essas formas poderiam representar um estágio inicial de formação de lagoas, baías ou salinas, nessa região. Neste sentido, o presente trabalho pode ser uma contribuição para futuras pesquisas sobre a gênese do sistema lacustre da Nhecolândia (MS).

Este trabalho se organiza em sete tópicos, a saber:

O primeiro tópico contém uma introdução com as justificativas do trabalho. $O$ segundo apresenta uma revisão bibliográfica da área, com uma parte dedicada ao Pantanal Mato-Grossense, e outra, à Nhecolândia, onde se inserem as áreas de estudo, e por último, os objetivos específicos da pesquisa.

O terceiro tópico se refere aos materiais e métodos utilizados no decorrer do trabalho, que incluem campo, laboratório e trabalhos de gabinete. O quarto é dedicado à apresentação dos resultados, seguido pelas respectivas discussões no tópico cinco.

As considerações finais da pesquisa são apresentadas no tópico seis, e no tópico sete as referências bibliográficas.

Esta pesquisa se desenvolveu no quadro do Projeto FAPESP 2008/09086-7, e contou com auxílio de bolsa pela FAPESP Processo no 2009/10943-4. 


\section{1 - INTRODUÇÃO E JUSTIFICATIVA}

As funções ambientais das áreas úmidas são hoje amplamente reconhecidas, com tendência mesmo de quantificar seus valores econômicos pelos "serviços ambientais" que podem prestar (Costanza et al., 1997; Siedl e Moraes, 2000). Porém, muitas perguntas e incertezas ainda subsistem sobre suas funções em diferentes ambientes e escalas de abordagens, desde a local envolvendo processos de funcionamento, até as regionais e globais envolvendo balanços climáticos, e ciclos globais de elementos químicos. Em função disto, observa-se atualmente um grande desenvolvimento de estudos sobre áreas úmidas em todos os quadros geográficos, e em todas as áreas do conhecimento.

O Pantanal Matogrossense é considerado a maior planície alagada do mundo, um dos mais expressivos exemplos de área úmida continental tropical. Dentro dele, a sub-região Nhecolândia apresenta, como principal particularidade, um complexo sistema lacustre formado por milhares de lagoas arredondadas, permanentes e/ou temporárias, com condições geoquímicas muito contrastadas, pois a curtas distâncias umas das outras, algumas são salinas e outras de água doce, as baías (Cunha, 1943; Barbiero et al., 2002).

Essa região tem sido objeto de recentes pesquisas, das quais se destacam aquelas voltadas aos processos pedológicos que acompanham a mineralização das águas (Rezende Filho, 2006; Furquim, 2007; Barbiero, et al., 2008). Os estudos de solos realizados entre lagoas contíguas mostraram que os regimes hídricos das lagoas são comandados por horizontes verdes argilosos, mais ou menos cimentados, cujos complexos sortivos, saturados em sódio ( $\mathrm{Na} / \mathrm{T}>25 \%$ ), limitam fortemente a permeabilidade. Esses horizontes funcionam como soleiras, e comandam os fluxos de águas subsuperficiais, cujos regimes passam a depender da altura que eles atingem localmente (Barbiero et al., 2008).

A presença desses horizontes vinha sendo associada ao ambiente alcalino do entorno das lagoas salinas (Sakamoto, 1997; Rezende Filho, 2006; Furquim, 2007; Furquim et al., 2004; 2008; 2009). Contudo, eles também foram encontrados em áreas não ocupadas por salinas, em pequenas depressões preenchidas com águas apenas durante as enchentes. 
Diante dessas observações as questões que se colocoram foram: (1) Quais as condições de formação desses horizontes e qual seria o seu papel em ambientes diluídos? Sabe-se que nas salinas esses horizontes funcionam como soleiras que comandam os fluxos subsuperficiais, e contribuem para a concentração de sais; (2) Seriam essas pequenas depressões um estágio inicial de formação de lagoas? Supõem-se que lagoas salinas podem ter sido formadas por rebaixamento geoquímico, em consequência do $\mathrm{pH}$ fortemente alcalino favorecer a dissolução do quartzo, com solubilização da sílica nos solos arenosos que a sustentam (Furquim, 2007). Essas questões ainda precisam ser confirmadas ou refutadas.

Um pré-requisito para responder a essas questões é, de um lado, identificar a morfologia dos solos nessas pequenas depressões, e de outro, estudar a dinâmica da água e dos elementos químicos que nelas circulam, ou seja, caracterizar o funcionamento atual dessas unidades da paisagem do Sul da Nhecolândia.

O estudo de processos pedológicos em áreas úmidas, como a planície do Pantanal, coloca o problema da própria organização do sistema pedológico. Considera-se que a água é o principal vetor das transformações dos solos. Em áreas bem drenadas, o eixo de organização coincide com a linha de maior declive das vertentes, e por isto, os sistemas pedológicos são melhor estudados partindo-se do topo em direção ao talvegue, as chamadas topossequências de solos descritas na análise estrutural da cobertura pedológica (Boulet et al., 1982).

Entretanto, em áreas rebaixadas e mal drenadas, com pequenos gradientes topográficos, a água pode vir tanto das chuvas quanto das oscilações do lençol freático, e por isto, o eixo de organização do sistema pedológico não é facilmente reconhecido a partir da superfície. Neste caso, é conveniente iniciar os estudos morfológicos dos solos pela terceira dimensão, ou seja, por suas distribuições espaciais numa dada área, e somente depois posicionar sequências que cortem as principais diferenciações, tal como preconiza a análise estrutural da cobertura pedológica.

Métodos indiretos de observação da morfologia do solo são empregados pela geofísica de subsuperfície, baseados na indução eletromagnética como é o caso dos aparelhos EM38 e EM31, que medem a condutividade elétrica aparente do solo em diferentes profundidades. Esses métodos não destrutivos são perfeitamente adequados para identificar a distribuição espacial dos sistemas pedológicos em áreas planas, cujos gradientes topográficos são muito pequenos. 
A dinâmica hídrica na Nhecolândia é complexa, pois além dos fluxos superficiais dos rios e vazantes que circulam na região, há também os fluxos subsuperficiais ligados às subidas e descidas do lençol freático. Monitoramentos do nível do lençol freático feitos por piezômetros, instalados em diferentes unidades da paisagem na Nhecolândia (Sakamoto, 1997; Bacani, 2004, Viana et al., 2006), mostram que as lagoas salinas são abastecidas por fluxos subterrâneos, e que as oscilações dessas águas são fundamentais para o funcionamento hídrico de cada unidade, mas também para a formação e/ou transformação da cobertura pedológica.

Nesse contexto, o objetivo geral deste trabalho foi compreender 0 funcionamento hídrico de três pequenas depressões, considerando-se as características morfológicas dos solos que nelas se desenvolvem. 


\section{2 - QUADROGERAL}

Neste tópico serão apresentados o Pantanal Mato-Grossense e uma de suas sub-regiões, a Nhecolândia, onde este trabalho foi realizado.

\section{1 - O PANTANAL MATO-GROSSENSE}

O Pantanal se localiza na Bacia do Alto Paraguai. Esta bacia é delimitada pelas nascentes do rio Paraguai ao norte, até a confluência do Paraguai com o rio Apa ao sul, e se estende entre os paralelos de latitude $14^{\circ}$ a $22^{\circ} \mathrm{S}$ e de longitude $53^{\circ}$ a $61^{\circ} \mathrm{W}$ (Carvalho, 1986).

A planície do Pantanal é uma das maiores áreas úmidas do Planeta, com aproximadamente 138.000 km² em território brasileiro, nos Estados de Mato Grosso e Mato Grosso do Sul. A sua extensão é de $250 \mathrm{Km}$ na direção Leste - Oeste, e 450 Km de Norte a Sul (Godoi Filho, 1986). Dada sua grande biodiversidade é reconhecida como um dos principais biomas brasileiros (Por, 1995; Silva e Abdon, 1998; Barbiero et al., 2002).

\section{A) Geologia e geomorfologia}

O Pantanal ocupa uma bacia sedimentar intracratônica quaternária, ainda tectonicamente ativa (Shiraiwa, 1994; Assine, 2003; Ab'Saber, 2006).

A sua origem vincula-se à própria formação da Bacia do Alto Paraguai, que é ligada à orogênia Andina ocorrida no final do Terciário. Essa orogênia provocou soerguimentos na Plataforma Brasileira, e reativou falhas preexistentes na Faixa Paraguai, localizada nos limites dos blocos cratônicos Amazônico e Paraná (Almeida, 1959). Entre o Terciário e o Pleistoceno, e concomitantes à subsidência da área do Chaco e do Pantanal, esses soerguimentos foram acompanhados de 
intensos processos erosivos, ainda atuantes (Franco \& Pinheiro, 1982; Ab'Saber, 2006).

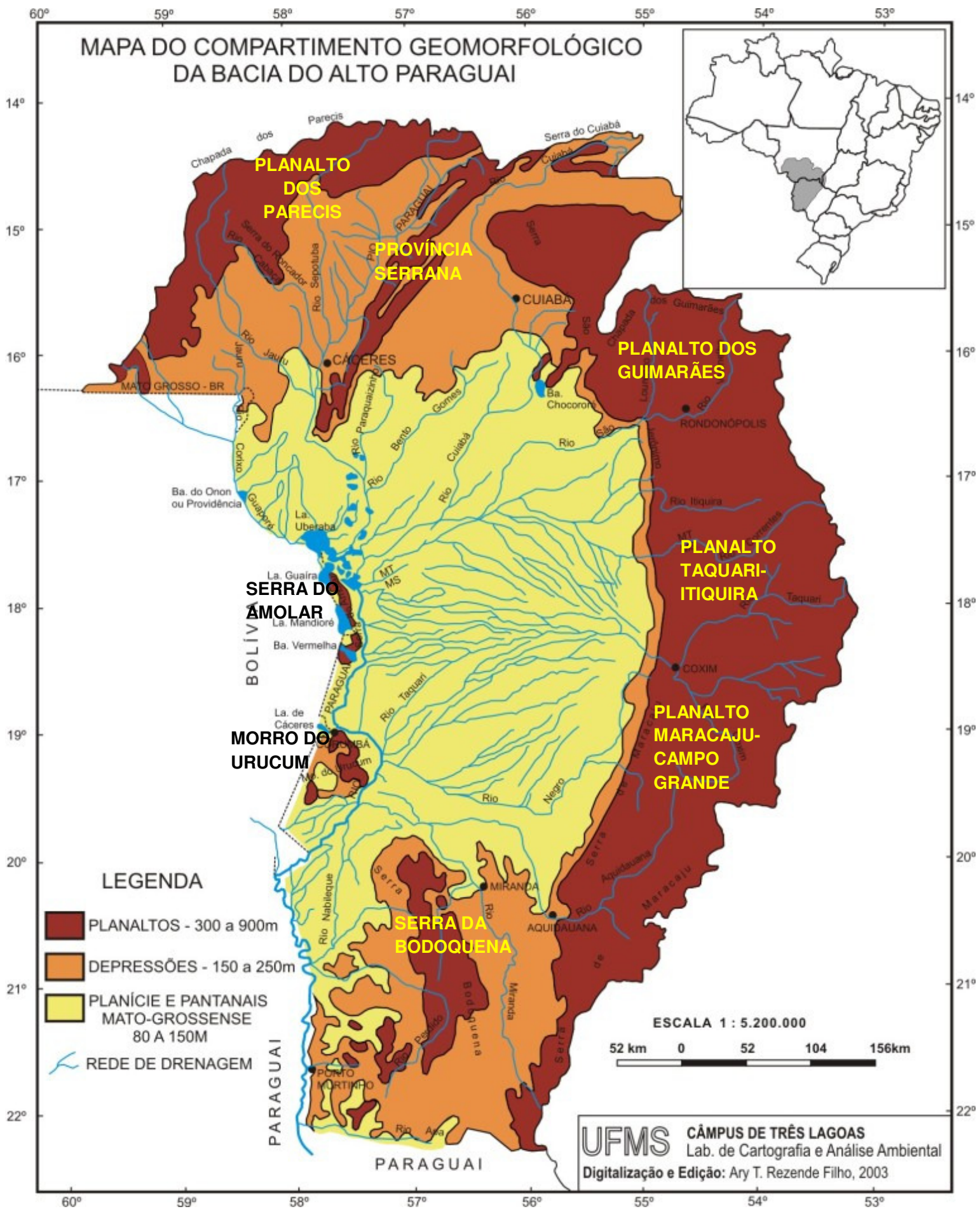

Figura 1 - Bacia do Alto Paraguai e seus grandes compartimentos geomorfológicos (Alvarenga et al.,1984). 
Durante o Quaternário, a bacia do Pantanal foi sendo preenchida por sedimentos arenosos, depositados discordantemente sobre rochas metassedimentares e metamórficas do proterozóico da Faixa Paraguai. Essas rochas afloram ao norte, leste e sul do Pantanal, e a noroeste, oeste e sudoeste do Cráton Amazônico (Almeida, 1964; Shiraiwa, 1994).

A Bacia do Alto Paraguai é compartimentada em três grandes unidades geomorfológicas (Figura 1), a saber, os Planaltos que a circundam, com cotas altimétricas que variam de 300 a 900 metros; as Depressões, com cotas entre 300 e 150 metros; e as Planícies e Pantanais Mato-Grossense cuja altimetria está na faixa de 150 a 80 metros (Alvarenga, et al, 1982; 1984; Barros, et al., 1982; Del'Arco, 1982; Franco \& Pinheiro, 1982; Godoi Filho, 1986).

A distribuição dos Planaltos, segundo o RadamBrasil (1982), é a seguinte:

\section{- Ao norte:}

1) o Planalto dos Parecis, esculpido principalmente em rochas sedimentares areníticas, Mesozóicas, do Grupo Parecis;

2) a Província Serrana, talhada em rochas Pré-Cambrianas dos Grupos Alto Paraguai e Corumbá;

3) o Planalto dos Guimarães, cujas bordas ocidentais são compartilhadas com a Bacia do Paraná, possui litologia Detrítico-Laterítica do Terciário-Quaternário, e arenitos da Formação Furnas, e siltitos, arenitos finos e folhelhos intercalados das Formações Aquidauana e Ponta Grossa.

\section{- A leste aparecem:}

1) os Planaltos Taquari-Itiquira formados, principalmente, por arenitos das Formações Furnas e Ponta Grossa do Grupo Paraná, e das Formações Bauru e Aquidauana;

2) e o Planalto de Maracaju-Campo Grande onde afloram rochas précambrianas do Grupo Cuiabá. Da borda para o interior desse planalto ocorrem sucessivamente litologias devonianas e carboníferas das Formações Furnas, Ponta Grossa e Aquidauana;

\section{- Ao sul:}

O Planalto da Bodoquena compreende um conjunto de relevos residuais dispostos na direção norte-sul, formados, principalmente, por rochas graníticas do Pré-Cambriano Inferior e Superior; e secundariamente, por rochas carbonáticas do Grupo Corumbá nas quais se desenvolvem relevos cársticos; 
- A oeste aparecem os planaltos residuais,

1) de Urucum-Amolar, ou Maciço de Urucum, que compreende um conjunto de morrarias onde predominam rochas silisiclásticas do Grupo Jacadigo;

2) e do Alto Guaporé com rochas metassedimentares Pré-Cambrianas do Grupo Aguapeí.

O Planalto dos Parecis apresenta relevo dissecado com topos convexos, limitados por escarpas estruturais e amplos interflúvios com topos aplainados a tabulares. Os Planaltos dos Guimarães, Taquari-Itiquira e Maracaju-Campo Grande limitam-se com as depressões por escarpas estruturais e frentes de cuestas. Os planaltos isolados, como a Província Serrana, Planalto da Bodoquena, UrucumAmolar e do Alto Guaporé, possuem características de relevos residuais esculpidos em rochas Pré-Cambrianas com cristas assimétricas e bordas escarpadas (RadamBrasil, 1982; Rezende Filho, 2011).

Em um nível intermediário, entre os Planaltos e a Planície, ocorrem as chamadas Depressões que se configuram como vastas superfícies rebaixadas que contornam toda a planície pantaneira. Elas são mais extensas ao norte e ao sul da Bacia do Alto Paraguai, e muito estreitas em suas porções nordeste, leste e sudeste. As Depressões ao norte e noroeste são constituídas pelas Depressões do rio Paraguai e do Guaporé em rochas do Pré-Cambriano e Cambriano ora aflorantes, ora se alojando sob sedimentos quaternários e, principalmente, recobertas por sedimentos cenozóicos da Formação Guaporé. Compreende extensas superfícies aplainadas onde aparecem formas pedimentadas e dissecadas com topos planos a convexos (Franco \& Pinheiro, 1982).

O embasamento da Planície é essencialmente formado por sedimentos, denominados Cobertura Detrítico-Laterítica, Depósitos Detríticos, Formação Xaraiés e Formação Pantanal (Franco \& Pinheiro, 1982).

Atualmente, a planície possui extensas superfícies de acumulação com topografia bastante plana, e frequentemente sujeitas a inundações. Essa unidade possui duas feições morfológicas distintas, as planícies e as áreas de acumulações inundáveis. A primeira compreende as planícies flúvio-lacustres ligadas, particularmente, ao rio Paraguai e seus tributários da margem esquerda; a segunda compreende as áreas que se situam em posições interfluviais entre os rios de maior importância, e apresentam drenagem mal definida composta por corixos, vazantes e baías (Franco \& Pinheiro, 1982; Alvarenga, et al., 1982). 
Em consequência dos baixos gradientes topográficos na planície pantaneira, os rios tendem a formar redes de padrões distributários, com pequena velocidade de corrente em canais pouco profundos, resultantes do volume de sedimentação e assoreamento a que são submetidos. Por isto, é comum a formação de leques aluviais, cujos canais distributários apresentam grande mobilidade lateral, e frequentes mudanças no traçado (Assine, 2008). No Pantanal ocorrem vários leques aluviais, como o do Cuiabá, Aquidauana, São Lourenço, e o mais notável de todos, o do rio Taquari (Figura 2).

O leque do Taquari tem forma circular sobre uma área de aproximadamente $50.000 \mathrm{Km}^{2}$, equivalentes a $37 \%$ da área total do Pantanal. Limita-se ao norte e noroeste pelos rios Piquiri e Cuiabá, a oeste e sul pelos rios Paraguai e Negro respectivamente, e a leste pelos planaltos de Maracaju-Campo Grande e TaquariItiquira. As altitudes no rio Taquari variam de $190 \mathrm{~m}$ a montante a $85 \mathrm{~m}$ a jusante, o que gera um gradiente médio baixo de 36 cm/km (Braun, 1977; Assine, 2003; Furquim, 2007).

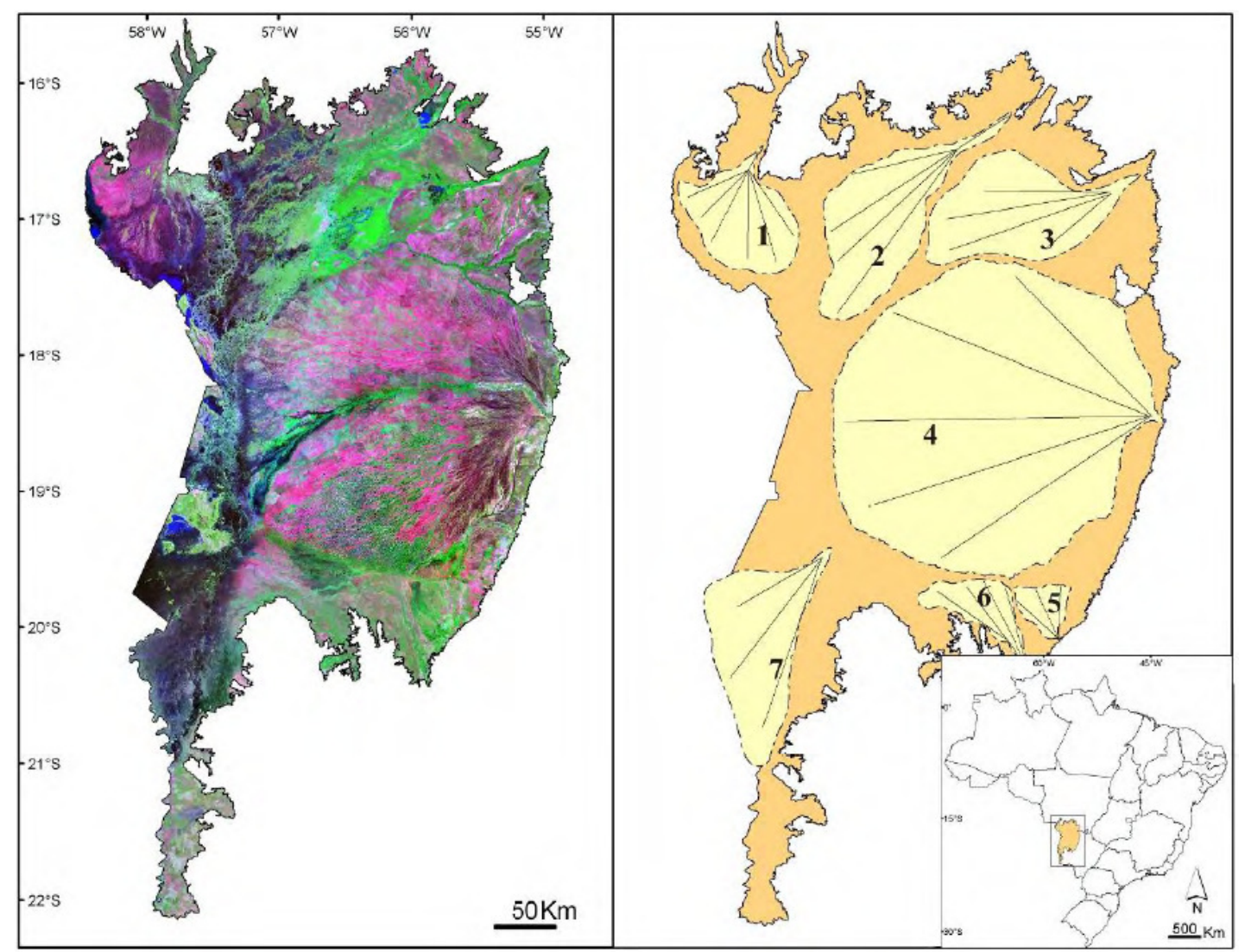

Figura 2 - Leques aluviais do Pantanal: 1 - Corixo Grande; 2 - Cuiabá; 3 - São Lourenço; 4 - Taquari; 5 - Taboco; 6 - Aquidauana, e 7 - Nabileque (Mosaico Landsat 4/5 GeoCover 1990, composição R7G4B2, Zani, 2008). 


\section{B) Hidrologia e química das águas}

A planície do Pantanal é drenada pelo rio Paraguai e seus tributários, principalmente os da margem esquerda (Figura 1). A direção geral do fluxo da água na planície de inundação é de leste para oeste até atingir o rio Paraguai, que corre de norte para sul (Hamilton, 2002).

Os principais afluentes que atravessam o Pantanal são: 1) na margem direita, o rio Jaurú, que nasce no Planalto dos Parecis e drena a porção noroeste do Pantanal; 2) na margem esquerda, os rios a) Cuiabá-São Lourenço, que nascem no Planalto dos Guimarães e drenam as partes norte e nordeste; b) Taquari, Miranda e Negro que drenam as porções leste e sudeste do Pantanal; c) e Abobral, que drena uma área de inundação localizada entre os rios Taquari e Miranda, e cuja descarga é altamente sazonal. Outros cursos de águas sazonais, localmente denominados de rios, são funcionais apenas durante as inundações, por exemplo, o Paraguai-Mirim e o Nabileque (Rezende Filho, 2011).

A análise do balanço hídrico regional mostra que a soma das descargas dos rios afluentes é aproximadamente igual ao fluxo de saída do Pantanal pelo rio Paraguai (Hamilton et al., 1996). Assim, a água perdida por evapotranspiração é mais ou menos equilibrada com as entradas diretas de precipitação, que variam de 1000 a 1300 mm/ano (Hamilton, 2002). Esse balanço hídrico regional pode variar substancialmente de um ano para outro devido à magnitude das enchentes.

Os gradientes topográficos da Planície são muito fracos, da ordem de 0,3 m a $0,5 \mathrm{~m} / \mathrm{km}$ na direção E-W, e de $0,03 \mathrm{~m}$ a $0,15 \mathrm{~m} / \mathrm{km}$ de N-S. Portanto, a velocidade das águas nos canais que atravessam o Pantanal atinge em média 1 a $5 \mathrm{~cm} / \mathrm{s}$ (Franco \& Pinheiro, 1982). A baixa declividade e a resistência imposta pela vegetação determinam o intervalo de tempo das enchentes, com defasagem média de dois a três meses entre o norte e o sul do Pantanal. As cheias e alagamentos que ocorrem não estão ligados diretamente à pluviosidade, mas sim aos problemas de drenagem expressos pela dificuldade de escoamento das águas (Carvalho, 1986; Silva, 1986; Ab'Saber, 2006).

Gradientes topográficos, tipos de vegetação, diferentes áreas de inundações, além do relevo têm sido, desde a década de 40 , considerados como critérios para recortar, em compartimentos homogêneos, a planície do Pantanal em sub-regiões 
(Moura, 1943; Pereira, 1944; Franco \& Pinheiro, 1982; Alvarenga et al., 1984; Amaral Filho, 1986; Silva e Abdon, 1998; Rezende, 2011).

Estudos feitos por Rezende Filho (2011) definem uma nova compartimentação do Pantanal baseada na variabilidade química das águas dos rios que entram na Planície. O autor mostra que as águas dos rios podem ser consideradas misturas de 3 pólos químicos que se distribuem espacialmente em grandes áreas. $\mathrm{O}$ pólo 1, com maior influência de $\mathrm{NH}_{4}, \mathrm{NO}_{2}$ e $\mathrm{NO}_{3}$, aparece em dois pontos isolados a leste da planície, e foi atribuído ao uso e ocupação dos solos nos planaltos. O pólo 2, determinado pelos teores de $\mathrm{Na}, \mathrm{K}$ e $\mathrm{Si}$, domina aproximadamente $70 \%$ da área do Pantanal, abrangendo os leques do Taquari e Taboco, a bacia do rio Negro e uma área situada entre os rios Correntes e São Lourenço. Este pólo é influenciado pelas rochas areníticas e cristalinas dos Planaltos. Finalmente, o pólo 3, determinado por $\mathrm{Ca}, \mathrm{Mg}$ e Alcalinidade carbonatada, tem suas áreas de influência nos extremos norte e sul do Pantanal onde ocorrem rochas calcárias. O trabalho também salienta as áreas de maiores contrastes químicos situadas ao longo do rio Cuiabá, ao norte, e ao longo do complexo Negro, Aquidauana e Abobral, ao sul.

\section{C) Clima, vegetação e tipos de solos}

Um dos fatores de maior influência no clima do Pantanal é a configuração do relevo da Bacia do Alto Paraguai, que propicia a formação de um núcleo de baixa pressão na Planície, decorrente da intensa radiação solar que recebe. Por sua vez, as altitudes dos Planaltos de leste propiciam o aumento das chuvas e amenizam o clima (Loureiro, et al., 1982).

O Pantanal é controlado por sistemas atmosféricos equatoriais, como a Massa Equatorial Continental, e tropicais, como as Massas Tropical Atlântica e Tropical Continental, responsáveis pelo regime de seca e estabilidade. Conta também com a considerável atuação extratropical da Massa Polar Atlântica, que provoca quedas de temperatura (Loureiro et al., 1982; Mendonça, 2007).

Com a atuação dessas massas ao longo dos anos, o clima se caracteriza pela alternância de estações quente e úmida de outubro a março, e fria e seca de abril a 
setembro, e ciclos de anos muito chuvosos a relativamente secos. A precipitação média anual varia de 800 a $1200 \mathrm{~mm}$, e a temperatura média anual é de 25,5ㄷ $\mathrm{C}$ (Galdino, et al., 2002). Essas características o enquadram no tipo Aw, clima tropical com estação seca, segundo a classificação de Köppen. Esse tipo de clima é ligado, principalmente, a fatores como latitude tropical e continentalidade que, associados às condições topográficas rebaixadas, determinam seu caráter megatérmico (Tarifa, 1986).

A cobertura vegetal do Pantanal se originada convergência de quatro grandes províncias fitogeográficas que o circundam: a da Floresta Amazônica a noroeste da Bacia do Alto Paraguai; a do Cerrado, com maior expressão em área, recobre a porção centro-leste do Pantanal; as florestas semideciduais e deciduais ao sul e sudeste, nas proximidades da Serra da Bodoquena; e a da vegetação do Chaco, na parte oeste do Pantanal. Contudo, o Cerrado constitui sua maior expressão fitogeográfica, com alternância de fisionomias como o Cerradão, Cerrado, Campo Cerrado, Campo, Campo inundável e Mata galeria (Loureiro et al., 1982; Adámoli, 1986).

Os tipos de solos identificados no Pantanal pelo RadamBrasil (1982) estão apresentados na Figura 3, e abaixo estão listados os tipos de solos mais expressivos, esuas correspondências com a atual nomenclatura, segundo a EMBRAPA (2006):

- Laterita Hidromórfica (Plintossolos);

- Solonetz Solodizado (Planossolos);

- Vertissolos (Vertissolos);

- Solos Aluviais (Neossolos);

- Glei Pouco Húmico (Gleissolos);

- Podzólicos Vermelho-Amarelo (Argissolos);

- Podzóis Hidromórficos (Espodossolos);

- Areias Quartzosas Hidromórficas (Neossolos Quartzarênicos).

$\mathrm{Na}$ porção norte do Pantanal aparecem os plintossolos, com horizonte subsuperficial de textura mais argilosa; na porção central, a presença de espodossolos indica solos mais arenosos, e na sul, onde aparecem os vertissolos e planossolos, os solos também são mais argilosos (Oliveira et al., 1982; Macedo, 1982; Orioli et al., 1982; Amaral Filho, 1986). 


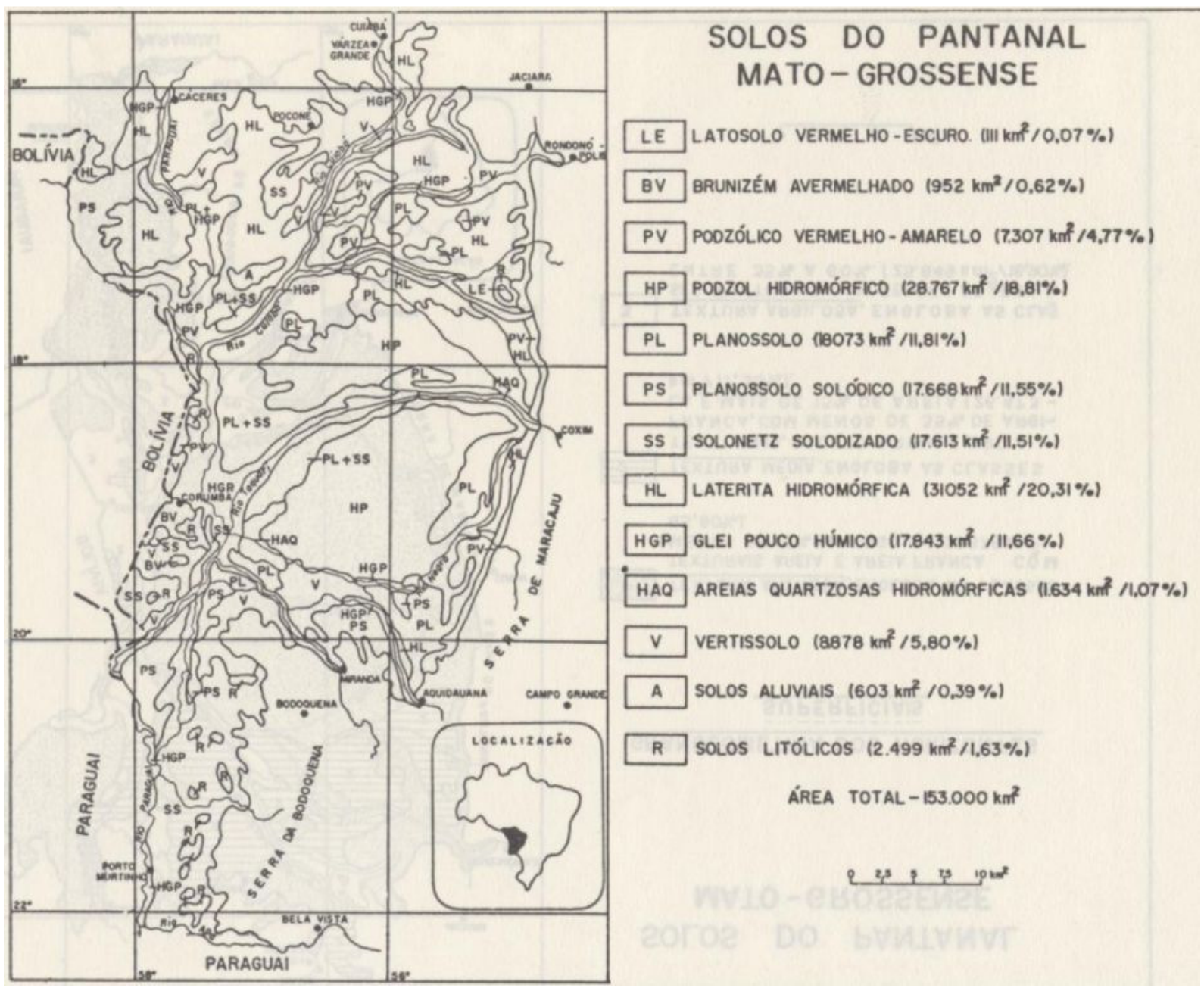

Figura 3 - Carta dos solos do Pantanal (RadamBrasil, 1982).

\section{D) Resumo}

O Pantanal é uma das maiores áreas úmidas continentais do planeta, e apresenta um sistema de drenagem particular, regido por inundações períodicas, que ocorrem todos os anos. Esses alagamentos não são homogêneos em toda a planície pantaneira, e com isto surgem zoneamentos com características diferenciadas, de vegetação, tipo de solo, níveis topográficos, dentre outros. Isto favoreceu diversas compartimentações do Pantanal, que passou a ser subdividido em sub-regiões. A Nhecolândia é uma delas, e local onde o presente trabalho foi desenvolvido, e que será apresentada a seguir. 


\section{2 - A NHECOLÂNDIA}

A Nhecolândia abrange toda a porção sul do leque aluvial do Taquari, onde ocupa uma área de $27.000 \mathrm{Km}^{2}$ (Silva e Abdon, 1998). Limita-se ao norte pelo rio Taquari, ao sul pelo Negro, a leste pela escarpa da Serra de Maracaju e a oeste pelo rio Paraguai (Figura 4).

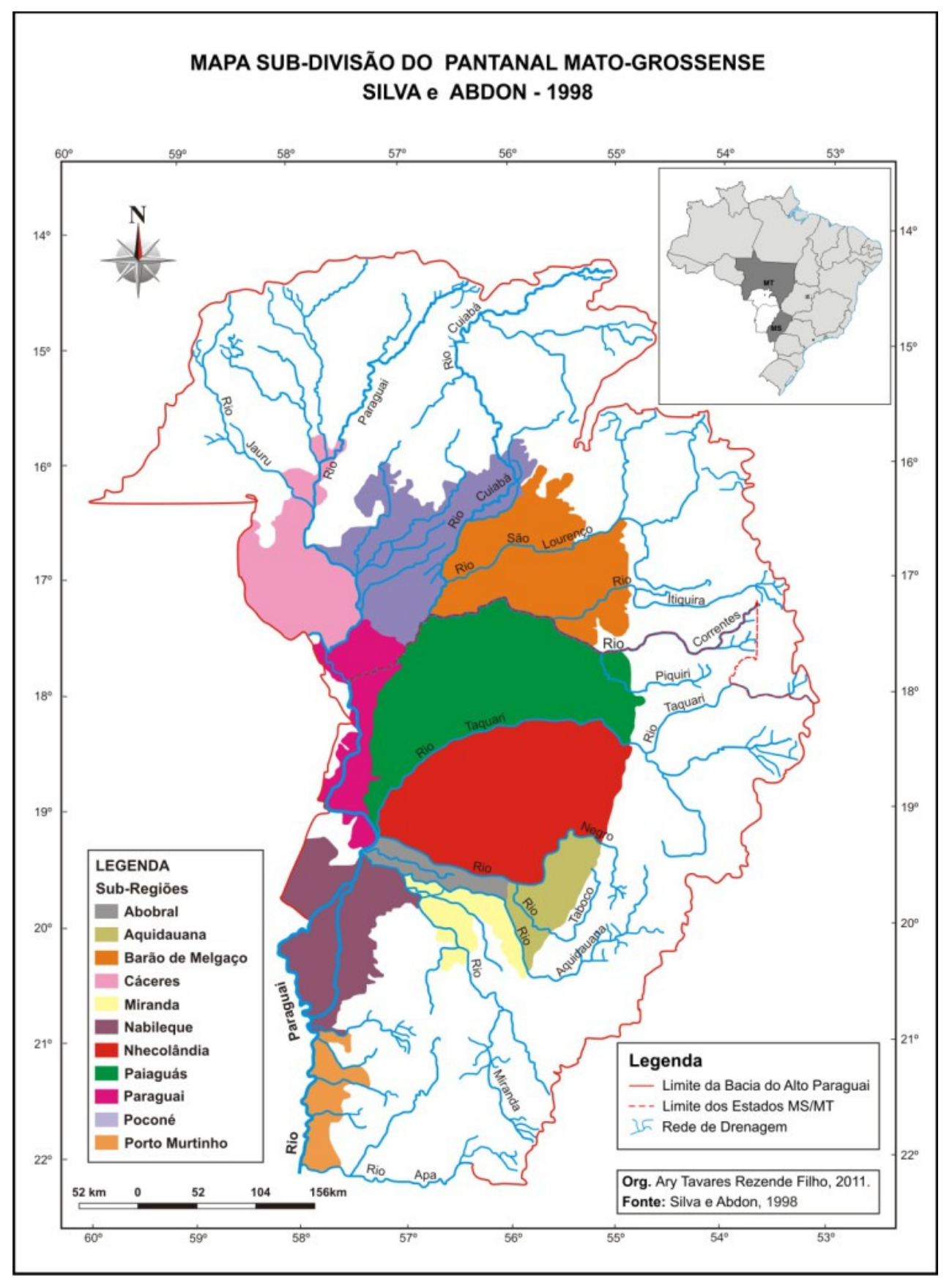

Figura 4 - As sub-regiões do Pantanal (Silva e Abdon, 1998). 


\section{A) Feições morfológicas e topografia}

$\mathrm{Na}$ Nhecolândia se observam diferentes unidades de paisagem (Franco \& Pinheiro, 1982; Barbiero et al., 2002) denominadas, em terminologia regional, de baías, salinas, cordilheiras, corixos e vazantes (Figura 5), isto é:

(1) baías: são áreas deprimidas, com formas circulares, semicirculares ou irregulares, com água doce temporária ou permanente, que no geral podem chegar a 2 metros de profundidade. Suas dimensões variam de dezenas a centenas de metros, e são distribuídas espacialmente com certa linearidade, uma vez que são conectadas à rede fluvial;

(2) salinas: são lagoas permanentes, com águas salinas, de 500 a 1000 metros de diâmetro, e 2 a 3 metros de profundidade, cercadas por cordilheiras, e geralmente não são atingidas pelas águas superficiais das cheias;

(3) cordilheiras: são pequenas elevações do terreno, espécie de cordões arenosos, em média com 2 a 5 metros de altura e 200 a 300 metros de largura. Constituem áreas quase nunca alagadas, recobertas por vegetação de cerrado;

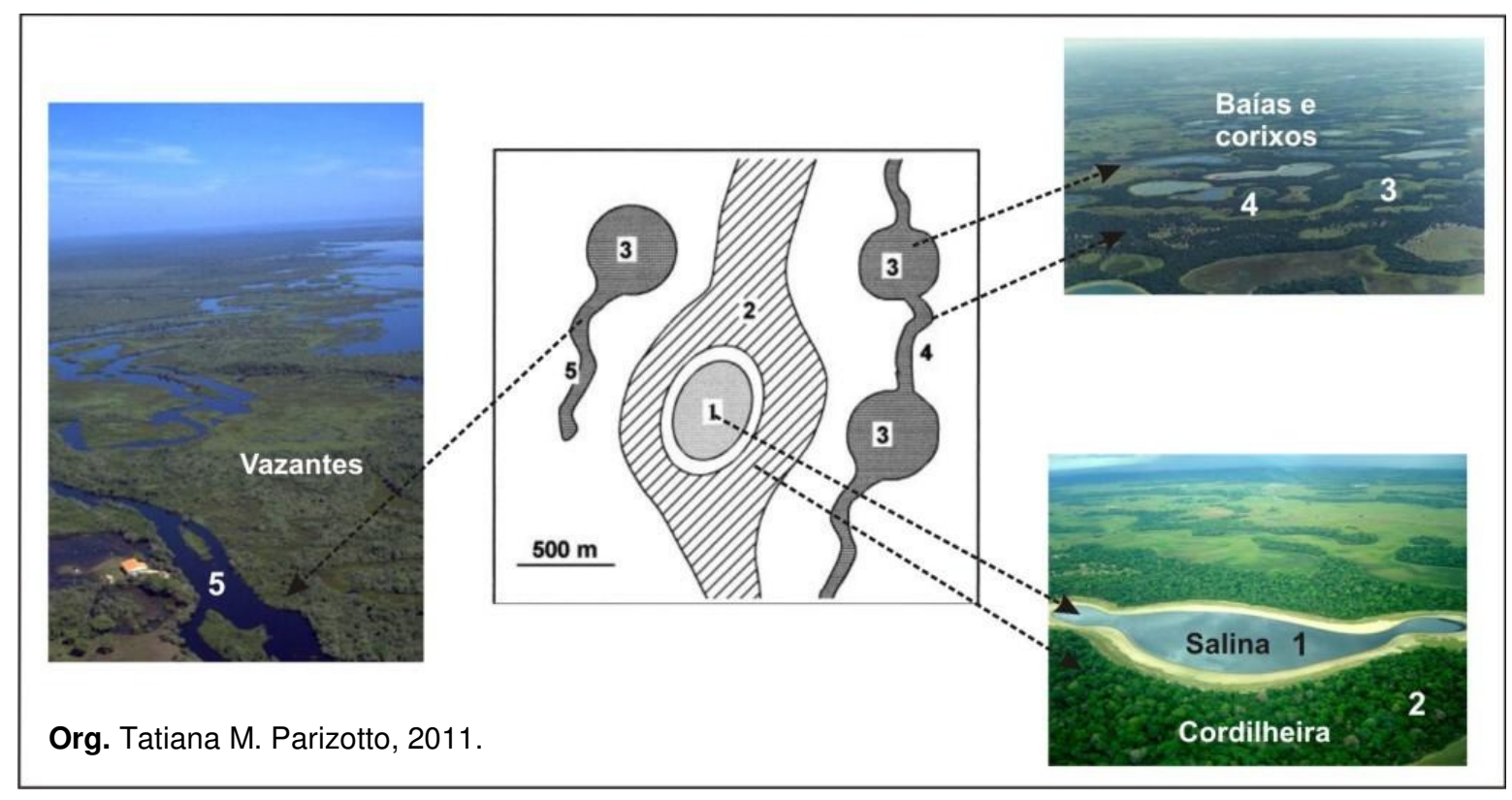

Figura 5 - Feições morfológicas da Nhecolândia (Barbiero et al., 2002).

(4) vazantes: compreendem amplas depressões suaves situadas entre cordilheiras e que servem de escoadouro entre as baías nas épocas de enchentes, 
daí seu caráter de curso fluvial intermitente, com vários quilômetros de extensão e 10 a 30 metros de largura;

(5) e corixos: são pequenos cursos de água que conectam baías contíguas através de canais mais estreitos e profundos, e de poder erosivo maior que as vazantes.

As diferenças altimétricas entre tais unidades morfológicas são muito suaves. Geralmente, as cordilheiras são 2 a 5 metros mais elevadas, e as lagoas salinas as mais rebaixadas, com desnível de $3 \mathrm{~m}$ em relação às cordilheiras. As lagoas de água doce, as baías, se encontram em um nível intermediário, sendo mais altas que as lagoas salinas e mais baixas que as vazantes (Sakamoto, 1997, Capellari, 2001).

As lagoas têm diferentes formas, com maior frequência, as circulares e elípticas, e podem estar alinhadas e conectadas umas às outras, como um rosário, ou então, isoladas por cordilheiras (Franco \& Pinheiro, 1982; Assine, 2003; $A b$ 'Saber, 2006). Elas cobrem uma superfície de cerca de $30 \%$ da área total da Nhecolândia durante a estação seca, das quais aproximadamente 500 são de água salina, equivalentes a $1 \%$ da área total (Morrison et al. 2000).

O mapeamento dessas lagoas, feito a partir de imagens de satélites, permitiu identificar um total de 25.000 unidades na época da cheia, das quais aproximadamente 21.000 são lagoas de água doce, as baías, e 4.000 de água salina, as salinas (Fernandes, 2005). Na Baixa Nhecolândia, técnicas de sensoriamento remoto (imagens Landsat-TM 5 de 1988 e 1990) permitiram estimar aproximadamente 9.000 lagoas com dimensões superiores a $7.200 \mathrm{~m}^{2}$, das quais $84 \%$ são de água doce, e 16\% de água salina (Fernandes, 2007).

\section{B) Sistema de drenagem}

O sistema de drenagem na Nhecolândia é muito complexo, e segundo Hamilton (1999) dirigido por inundações sazonais que ocorrem em três condições diferentes:

(1) pelo transbordamento do rio Taquari que atinge principalmente sua porção norte; 
(2) pelo efeito da água estagnada nas inundações dos rios Paraguai e Negro, que local e temporariamente podem reverter o fluxo de algumas vazantes e corixos, e finalmente,

(3) pelas chuvas locais nas encostas suaves, que retardam a drenagem para os rios e aumentam o nível das águas no Pantanal.

No final dos anos 90, Hamilton (1999) já chamava a atenção sobre a falta de conhecimento dos fluxos subsuperficiais que conectam as diferentes lagoas. Estudos mais recentes realizados por Barbiero, et al. (2008) mostram que esses fluxos são fundamentais para o funcionamento hídrico das lagoas, e dependem, principalmente, das características morfológicas locais da cobertura pedológica. Tais estudos permitiram aos autores de propor um modelo de funcionamento hidroquímico de uma salina, e de uma baía na Fazenda Nhumirim (EMBRAPA).

Esse modelo, apresentado na Figura 6, mostra que as bordas da salina são circunscritas por um horizonte subsuperficial argiloso, pouco permeável, que atua como uma soleira para o lençol freático. Na estação úmida, as águas doces do lençol freático ultrapassam essa soleira e alimentam a lagoa salina (1). Na estação seca, o nível da água do lençol abaixa e a soleira desconecta as águas do lençol com as da salina e impede a propagação de águas salinas no lençol freático de água doce (2). Como esse funcionamento possui um sentido único, as águas da salina se evaporam e se concentram. Esse processo é acumulativo e provoca extensas gamas de condutividade elétrica (CE), e pH nas águas dessa região.

Estudos estatísticos e geoestatísticos feitos a partir de duas variáveis, a condutividade elétrica e $\mathrm{o} \mathrm{pH}$ medidos em amostras de águas de 53 lagoas na Nhecolândia confirmam o modelo acima apresentado, inicialmente descrito apenas para duas lagoas contíguas, que pode, portanto, ser estendido para outras lagoas da Nhecolândia (Martins et al., 2011).

Em síntese, os mais recentes estudos na Nhecolândia salientam a relação de dependência entre fluxos subsuperficiais e morfologia do sistema pedológico. 


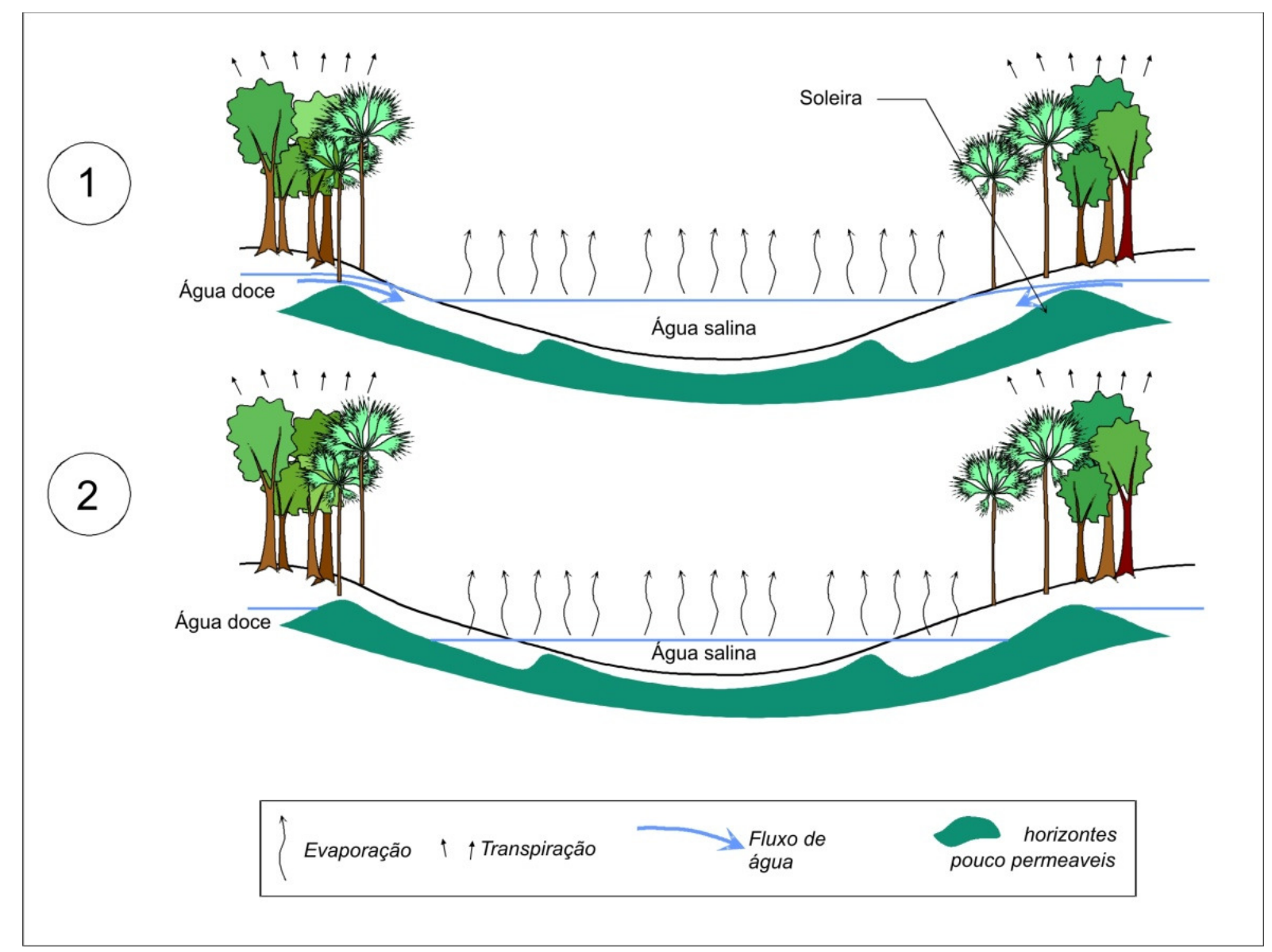

Figura 6 - 1) Na época da cheia as lagoas se conectam pela subida do nível do lençol freático; 2) ao contrário, na época da seca o nível do lençol abaixa e a conexão se interrompe, pois os horizontes pouco permeáveis passam a funcionar como soleiras. Consequentemente, passa a existir dois níveis de lençol, e as águas das salinas tendem a evaporar-se e a concentrar sais (Barbiero et al.; 2008).

\section{C) Solos, processos geoquímicos e pedológicos}

A Nhecolândia tem aproximadamente $95 \%$ de sua área recoberta por sedimentos arenosos finos, mais ou menos colmatados por partículas coloidais (Cunha, 1980). As áreas-fonte desses sedimentos, transportados pela rede fluvial do rio Taquari, localizam-se essencialmente no Planalto de Maracaju, onde se situa grande parte de suas nascentes (Furquim, 2007).

Três tipos principais de solos foram mapeados na região da Nhecolândia (Figura 7): os Espodossolos, anteriormente denominados Podzóis Hidromórficos (Radam Brasil, 1982; Cunha, 1981; EMBRAPA Pantanal, 1997; IBGE, 2001), os 
Planossolos, anteriormente denominados Solonetz-Solodizados (Cunha 1981), e os Neossolos, antiga classe das Areias Quartzosas Hidromórficas (Cunha, 1981; ANA, 2003).

Os Espodossolos foram mapeados nas partes central e sul da Nhecolândia (Radam Brasil, 1982; EMBRAPA Pantanal, 1997; IBGE, 2001), como mostra a Figura $7 \mathrm{E}, \mathrm{C}$ e D. Os Planossolos aparecem na porção sul do rio Taquari, e também a leste da Nhecolândia. Nota-se que para Cunha (1981) os Planossolos ocorrem somente na parte oeste, à jusante do rio Taquari (Figura 7 A). Os Neossolos aparecem a oeste, próximo ao rio Paraguai, a jusante do rio Negro (Radam Brasil, 1982; IBGE, 2001), e a sudoeste, abrange toda a extensão norte do rio Negro (Cunha, 1981). Os Neossolos ocupam praticamente o total da área da Nhecolândia pela classificação da ANA (1997), exceto numa mancha individualizada de Argissolo próximo ao rio Negro (Figura 7B).

No extremo leste da Nhecolândia, próximo a Serra de Maracaju, também ocorrem Lateritas Hidromórficas (Radam Brasil, 1982; Cunha, 1981), atualmente denominadas Plintossolos (Embrapa, 2006). Nota-se que a classificação da EMBRAPA Pantanal (1997), Figura 7 C, não identifica esse tipo de solo na Nhecolândia, mas na da ANA (2003) ele aparece nas margens do Taquari.

Nota-se que a maioria dos tipos de solos mapeados nessa área se desenvolvem em ambientes hidromórficos, ou seja, ambientes com excesso de água temporária e/ou intermitentemente. Porém, esses mapeamentos não permitem identificar os processos pedológicos nem o funcionamento hidroquímico dessa área, e isto justifica o desenvolvimento de estudos locais em cada unidade da paisagem. 

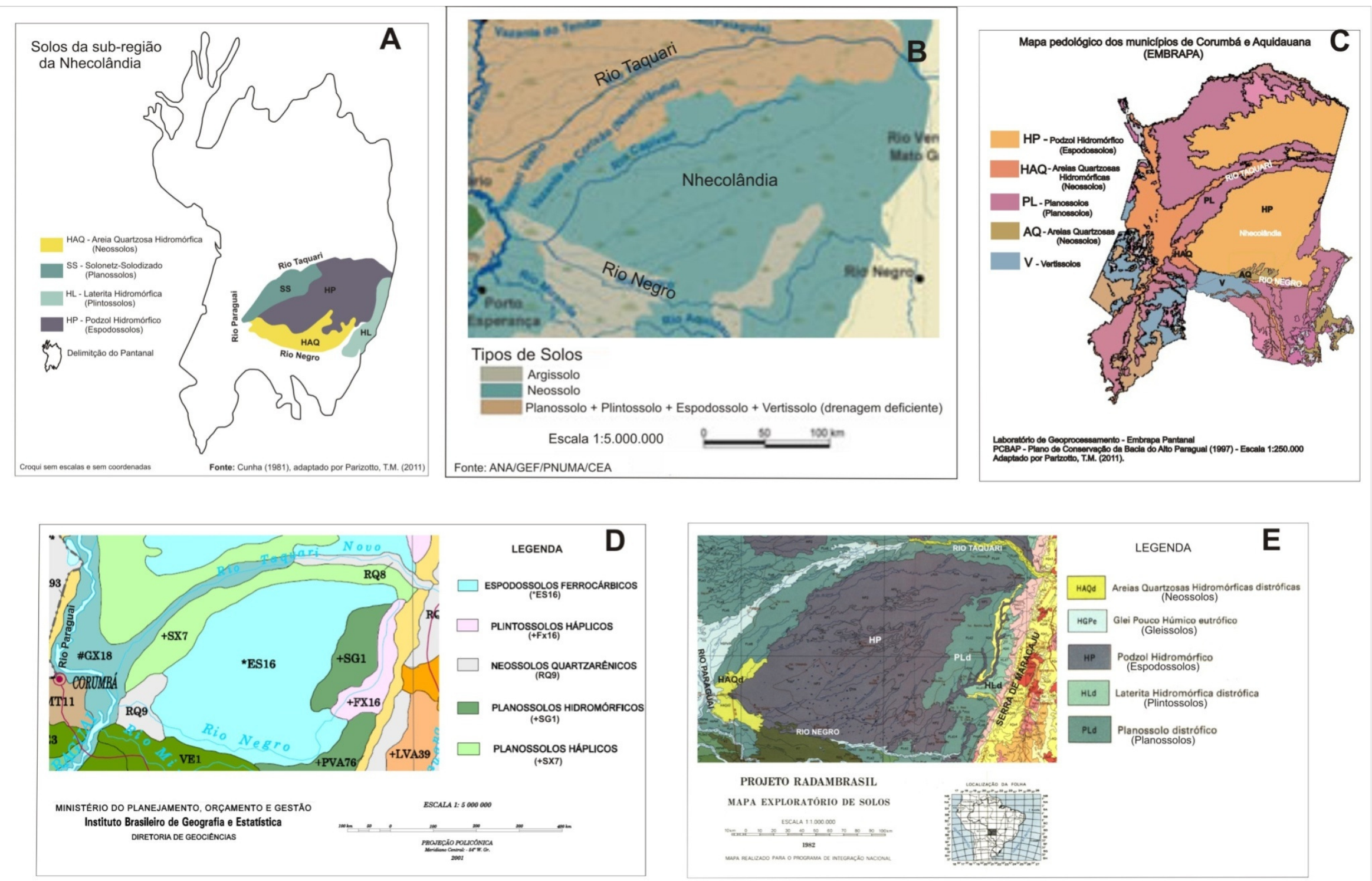

Figura 7 - Mapas de solos da Nhecolândia: (A) Cunha, 1981; (B) ANA, 2003; (C) EMBRAPA - PCBAP, 1997; (D) IBGE, 2001; (E) RadamBrasil, 1982. 


\section{Resumo}

Pela revisão bibliográfica nota-se que os sistemas de salinas são hoje bem conhecidos em seus aspectos pedológicos, e quanto aos seus funcionamentos hídricos. Percebe-se também que os horizontes verdes argilosos, mais ou menos cimentados, pouco permeáveis, constituem pontos-chaves neste sistema, pois atuam como soleiras que comandam os fluxos subsuperficiais das águas. Até recentemente, a presença destes horizontes foi descrita somente em ambientes alcalinos. Porém, eles também foram encontrados em ambientes diluídos não salinos, em baías e pequenas depressões no interior de vazantes e cordilheiras. Daí decorrem os objetivos específicos deste trabalho.

\section{3 - OBJETIVOS ESPECÍFICOS}

Os objetivos específicos são:

(1) testar o uso de métodos geofísicos, por indução eletromagnética, para identificar a distribuição dos solos nas pequenas depressões;

(2) descrever as características morfológicas dos sistemas pedológicos que se formam nas pequenas depressões, e suas características mineralógicas;

(3) tentar estabelecer relações entre os solos e as características físicoquímicas das águas circulantes nas depressões;

(4) implementar um sistema de monitoramento do nível de água do lençol freático entre uma baía e uma depressão. 


\section{3 - MATERIAIS E MÉTODOS}

\section{1 - MATERIAIS}

As pequenas depressões estudadas neste trabalho se situam na Fazenda Embiara, que se localiza ao sul da Nhecolândia, entre as coordenadas

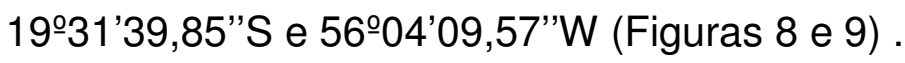

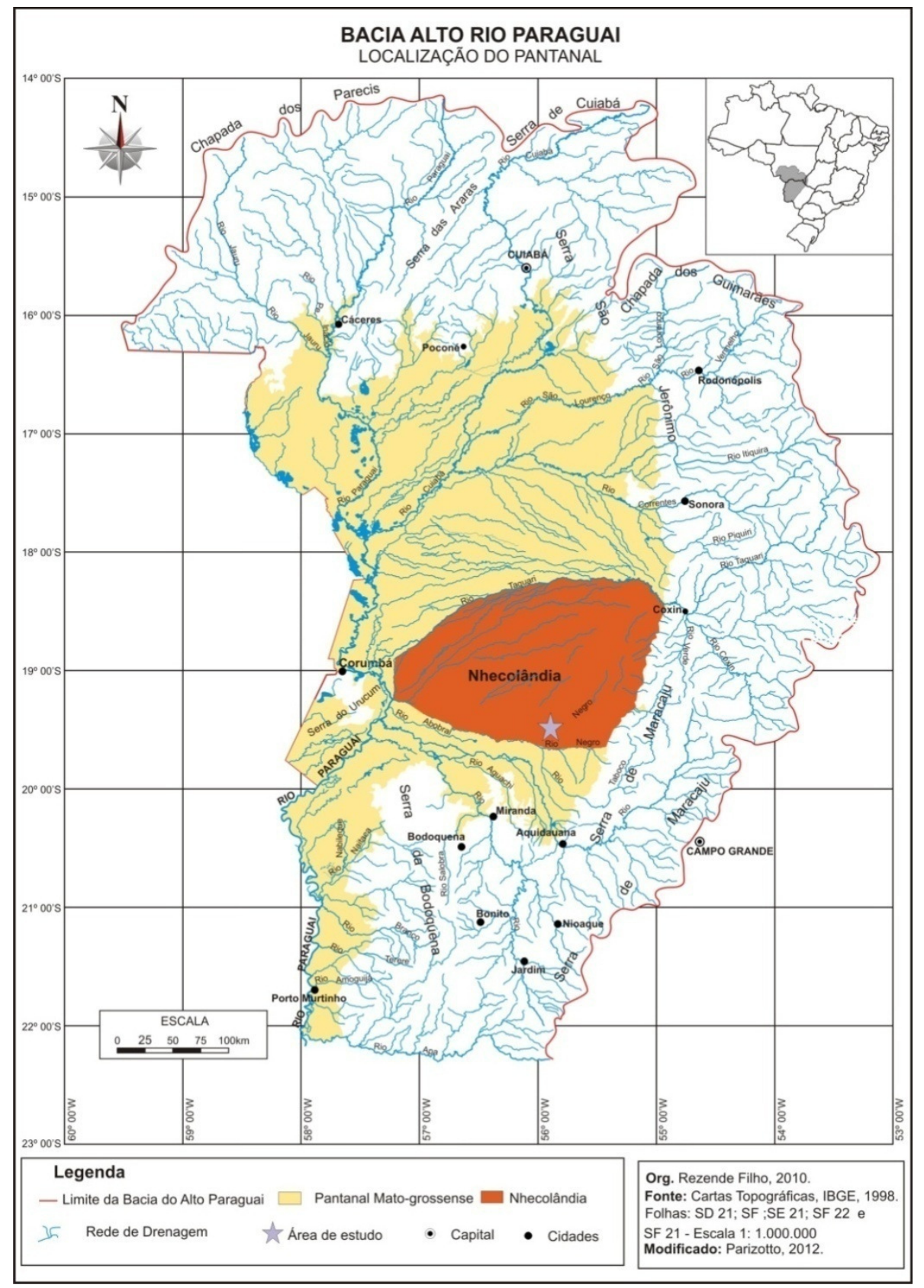

Figura 8 - Localização da área de estudo ao sul da Nhecolândia. 


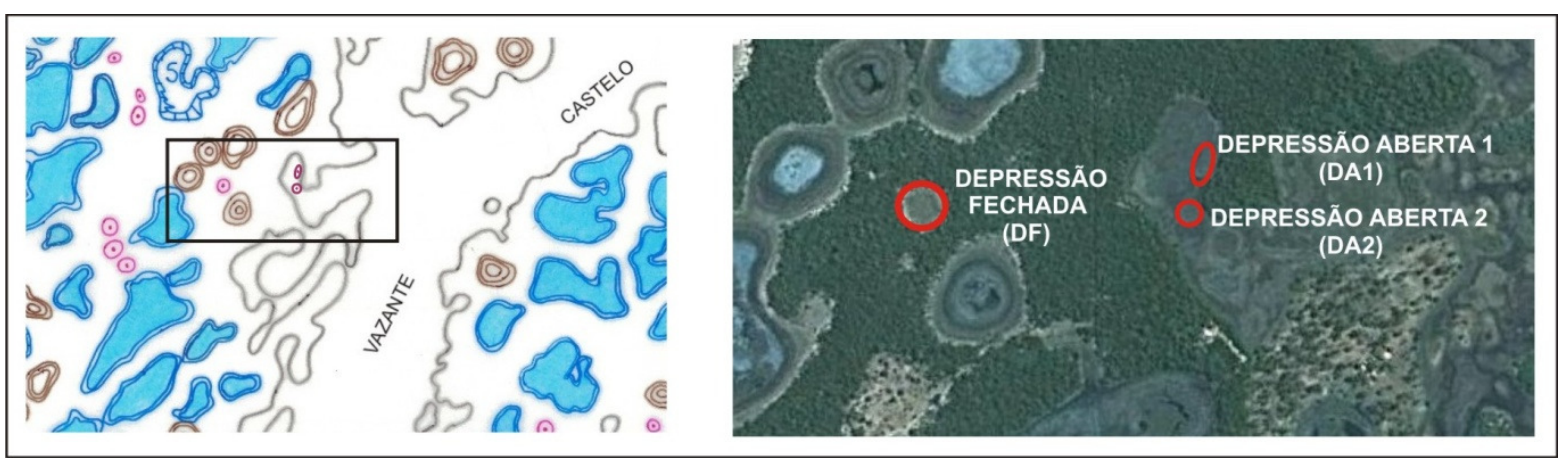

Figura 9 - Localização das três pequenas depressões estudadas.

\section{A) Depressões Abertas 1 (DA1) e 2 (DA2)}

As Depressões Abertas 1 e 2 se localizam em posições terminais de um dos braços da Vazante Castelo que deságua no rio Negro, ou seja, em um sistema aberto de drenagem. A DA1 tem 95 metros de diâmetro, de uma borda a outra até os limites com a cordilheira. Sua área é de aproximadamente $4 \mathrm{mil} \mathrm{m}^{2}$, possui forma oval, e se situa no limite vazante/cordilheira (Figura 10). No entanto, o seu acesso não foi mais possível após a cheia de 2010, mas foram aqui mantidas as descrições morfológicas dos solos anteriormente feitas. Por isto, encontrou-se outra depressão nesse mesmo local, a DA2.

A DA2 se situa um pouco mais no interior da Vazante Castelo, e é separada da DA1 por um terreno levemente mais elevado. Seu diâmetro é de 75 metros, com uma área de aproximadamente $3,4 \mathrm{mil} \mathrm{m}^{2}$, e forma circular (Figura 11).

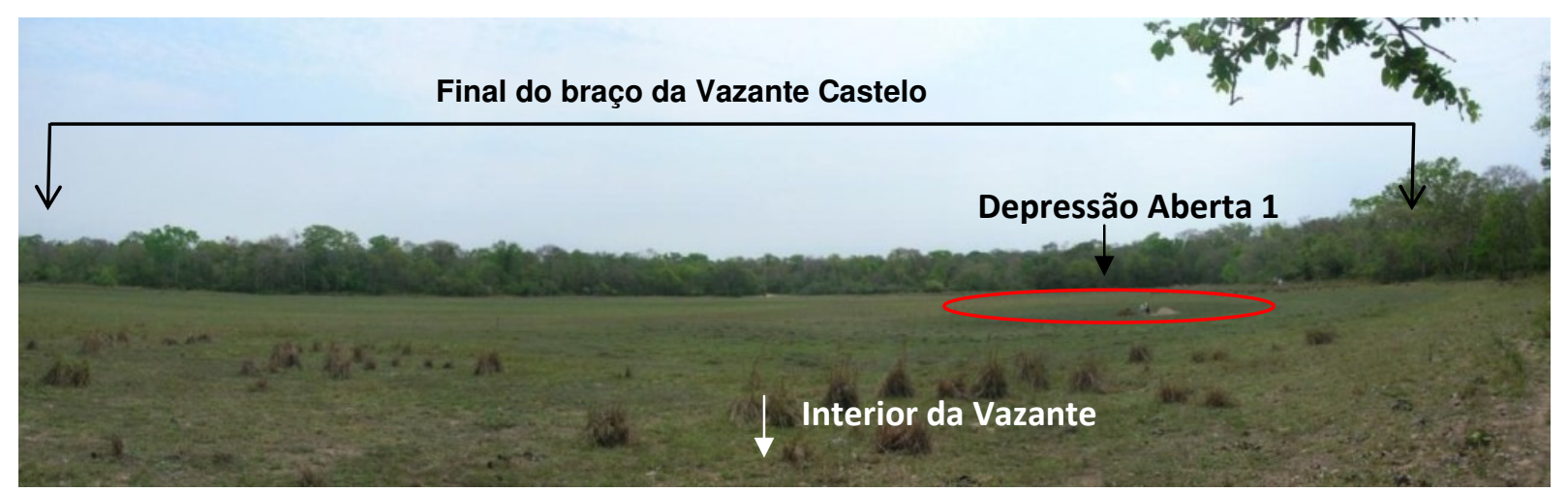

Figura 10 - Posicionamento da Depressão Aberta 1 no braço final da Vazante Castelo. 


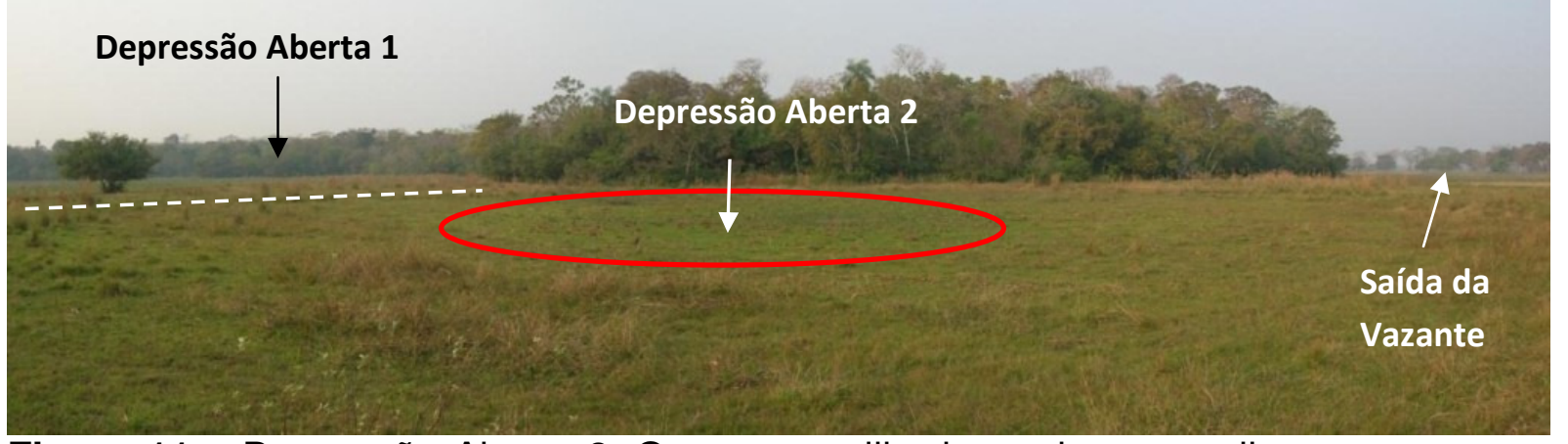

Figura 11 - Depressão Aberta 2. O traço pontilhado em branco salienta a pequena elevação do terreno que separa as duas depressões (DA1 e DA2).

\section{B) Depressão Fechada (DF)}

A Depressão Fechada é circundada por cordilheiras, seu diâmetro é de 120 metros, com uma área de aproximadamente $6,8 \mathrm{mil} \mathrm{m}^{2}$, e forma circular. Ela não apresenta conexão superficial com vazantes e rios da rede de drenagem (Figura 12).

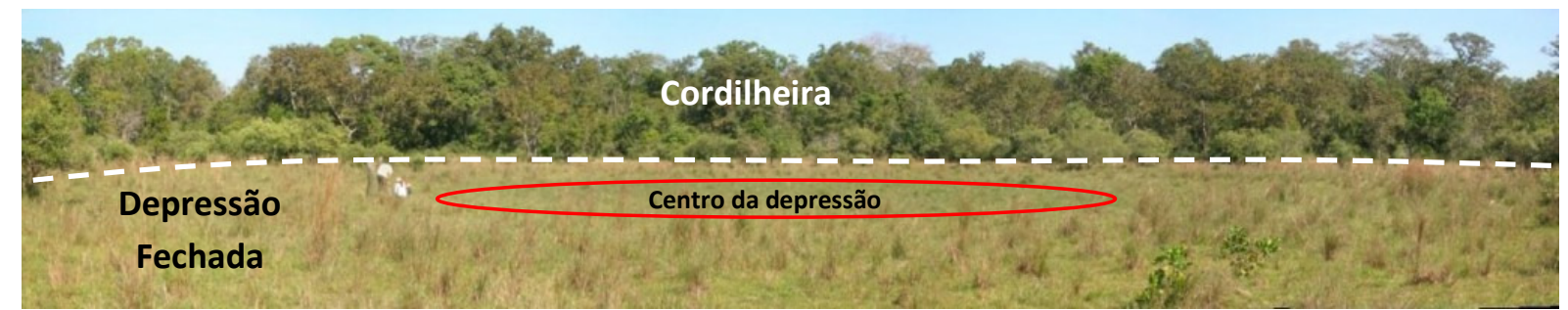

Figura 12 - Depressão Fechada circundada por cordilheira.

\section{2 - MÉTODOS}

Os diferentes métodos utilizados nesta pesquisa foram agrupados segundo os tipos de trabalhos desenvolvidos:

I) para confecção do mapa fisiográfico;

II) para estudos morfológicos dos solos, que incluem observações indiretas e diretas da cobertura pedológica. A primeira refere-se ao mapeamento da condutividade elétrica aparente (CEa) dos solos, com aquisição de dados 
georreferenciados, tratamentos estatísticos e análises de qualidade dos dados. A segunda trata do estudo das características morfológicas da cobertura pedológica;

III) para análises das características físicas dos solos: granulometria e natureza mineralógica da fração argila por difratometria de raio-x;

IV) para o monitoramento e características físico-químicas das águas. Este item inclui, de um lado, técnicas de confecção e instalação de piezômetros, e de outro, confecção e instalação de coletores de água do lençol freático.

Ressalta-se que as análises listadas nos itens III e IV não foram igualmente aplicadas em todas as depressões.

Os materiais utilizados para cada grupo serão apresentados nas respectivas descrições dos métodos.

\section{A) Confecção do mapa fisiográfico}

Os mapas da Bacia do Alto Paraguai com suas características físicas são facilmente encontrados, assim como os regionais das sub-regiões do Pantanal, com representação de áreas de inundações, leques aluviais, distribuição de solos, dentre outros.

Contudo, mapas feitos em grandes escalas não são facilmente encontrados. Por isto, e pelas necessidades da pesquisa, elaborou-se um mapa das principais unidades que aparecem na paisagem ao sul da Nhecolândia. $O$ objetivo foi fazer um inventário dessas unidades, e identificar suas relações espaciais e suas conexões, ou desconexão, com a rede de drenagem, e em particular, avaliar se as "pequenas depressões" constituem unidades morfológicas representativas nessa paisagem.

Para isto, fêz-se um corte em uma imagem de satélite (Google Earth, ano 2010), nas coordenadas $19^{\circ 2} 6^{\prime} 08,8^{\prime \prime}$ a 19 ${ }^{\circ} 35^{\prime} 52,9^{\prime \prime}$ S e 56 $6^{\circ} 10^{\prime} 57,8^{\prime \prime}$ a $55^{\circ} 58^{\prime} 20,5^{\prime \prime} \mathrm{W}$. Além deste material, utilizou-se uma mesa de luz; papel ultrafan, canetas esferográficas e lápis de cor.

A técnica empregada foi a da fotointerpretação de imagens, que busca identificar, interpretar e obter informações sobre os fenômenos e objetos nelas contidos (Fitz, 2008). Esta técnica foi complementada por uma pesquisa de legendas no âmbito das geomorfologias fluvial (Christofoletti, 1981; Ab'Saber, 2006), e 
cárstica (Coutard et al., 1978; Uagoda, 2006). A identificação das unidades da paisagem baseou-se em parâmetros como forma, cor, tamanho, textura, padrão e localização. Primeiramente, delineou-se a rede de drenagem, rios, vazantes e corixos; em segundo, os diferentes tipos de lagoas, e as pequenas depressões; e por último, uma averiguação dessas unidades no campo para confirmar suas interpretações, e testar suas legendas.

Em uma etapa posterior, com a fotointerpretação finalizada, quantificou-se as pequenas depressões na área. O objetivo foi, de um lado, verificar o número de ocorrência dessa unidade na área total do mapa, e de outro, verificar a área média dessas depressões em um quadrante representativo do mapa. Para isto, utilizou-se o software de geoprocessamento ArcGis 9.

\section{B) Morfologia dos solos}

I-Métodos indiretos

a) Princípio do método

A análise da cobertura pedológica se apóia na topografia do terreno para posicionar sequências de observações dos solos (Boulet et al., 1982). Porém, a topografia não é adequada para estudos de solos em áreas planas, com pequenos gradientes topográficos, onde o eixo de transformações da cobertura pedológica não segue, necessariamente, as variações topográficas mas sim as oscilações do nível do lençol freático (Rezende Filho, 2006; Furquim, 2007; Barbiero et al., 2008). Neste caso, é necessário utilizar ferramentas de análises não destrutivas do solo, que possibilitem, num segundo momento, posicionar as sequênciasde observações.

O método geofísico de indução eletromagnética de baixa frequência tem-se mostrado eficaz para resolver essa questão (Rezende Filho, 2006, Barbiero et al., 2008). Esta técnica de prospecção fornece mapas de condutividade elétrica aparente do solo, que servem como guia para posicionar sequências para 
observações diretas dos solos. Para fazer essa prospecção serviu-se dos aparelhos EM38 e EM31 (Geonics Ltda, Ontário, Canadá).

Esse método tem sido utilizado para diversos tipos de pesquisas em vários países. Por exemplo, na agricultura de precisão o EM38 serviu para avaliar a produtividade e as formas de gestão de diferentes tipos de solos (Sudduth, et al., 2001; Domsch e Giebel, 2004 ; Fraisse et al., 2001; Kitchen et al. 2005), mas também para cartografar a salinidade dos solos em ambientes naturais ou cultivados no Senegal (Gascuel-Odoux e Boivin, 1994; Barbiero et al., 2001), na China (Rongjiang et al., 2010), e na proximidade imediata das salinas na Nhecolândia (Rezende Filho, 2006; Barbiero et al., 2008). Por sua vez, o EM31 foi usado para espacializar a profundidade do manto de alteração de rochas em pequenas bacias experimentais (alguns $\mathrm{km}^{2}$ ) no sul da Índia (Barbiero et al., 2007).

Define-se condutividade elétrica (CE) a habilidadedo solo em transmitir (conduzir) corrente elétrica. Ela é uma das propriedades intrínsecas do solo, assim como a densidade, porosidade, dentre outras (Molin e Castro, 2006). Segundo Laureano (2007), a condutividade elétrica do solo pode variar em função:

a) da quantidade de água e ar presentes nos poros dos solos;

b) da salinidade, uma vez que o aumento da concentração de sais na água aumenta proporcionalmente a condutividade;

c) da quantidade e do tipo de argila e minerais condutivos existentes no solo.

Os métodos eletromagnéticos indutivos baseiam-se na propagação de ondas eletromagnéticas de baixa frequência $(<1 \mathrm{MHz})$, que é um fenômeno físico de eletricidade e magnetismo. O campo magnético é gerado ao redor de um fio onde passa uma corrente elétrica. Se este fio é colocado sobre a superfície do terreno fluem correntes elétricas nos condutores subsuperficiais, processo este conhecido como indução eletromagnética.

O princípio do método é regido pela emissão e recepção de correntes elétricas por aparelhos. O aparelho emite correntes elétricas por uma bobina transmissora e cria um campo eletromagnético primário em suas proximidades. Por sua vez, o campo primário produz fluxos de correntes secundárias em qualquer condutor presente, que são então captados por uma bobina receptora do aparelho (Elis, 2005; Oliveira, 2006). 
b) Material

Neste trabalho, as medidas de CE foram feitas com dois aparelhos, o EM31MK2 e o EM38-MK2, ambos da Geonics (Ontário, Canadá). A diferença entre eles é a distância entre bobinas transmissora e receptora, e frequência de indução (Foto 1).
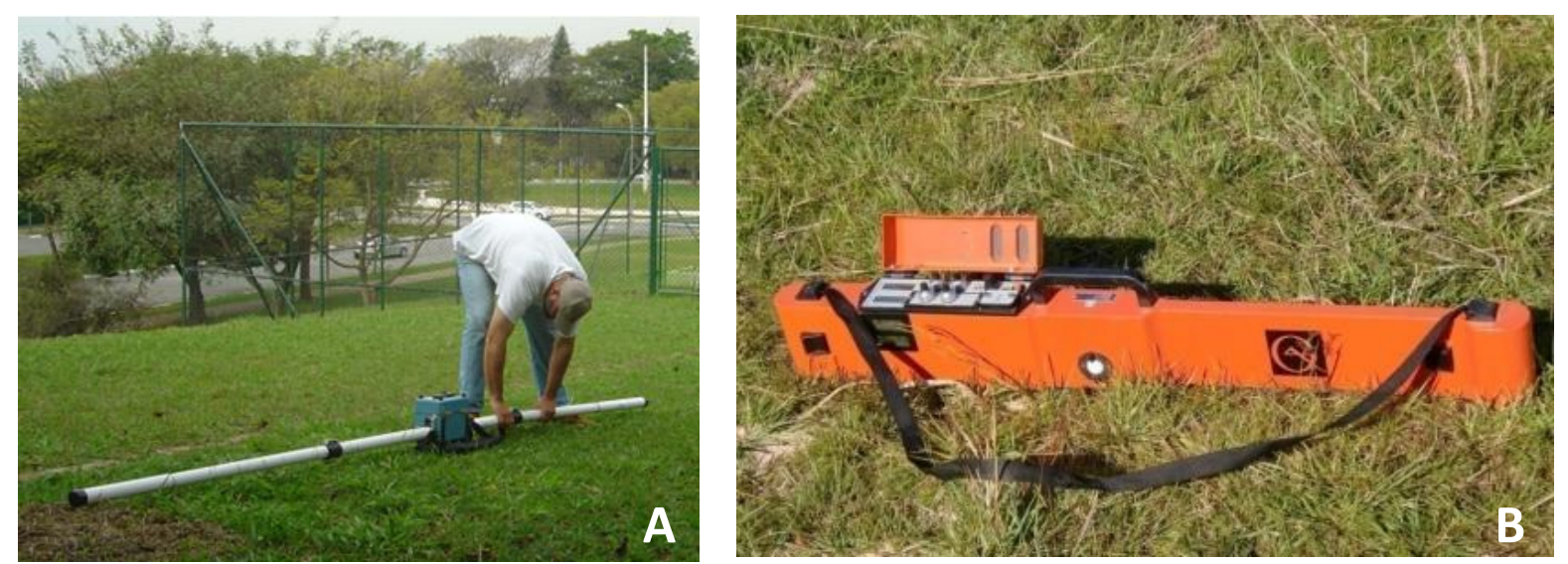

Foto 1: Aparelhos: (A) EM31-MK2 e (B) EM38-MK2.

A

Resposta EM31

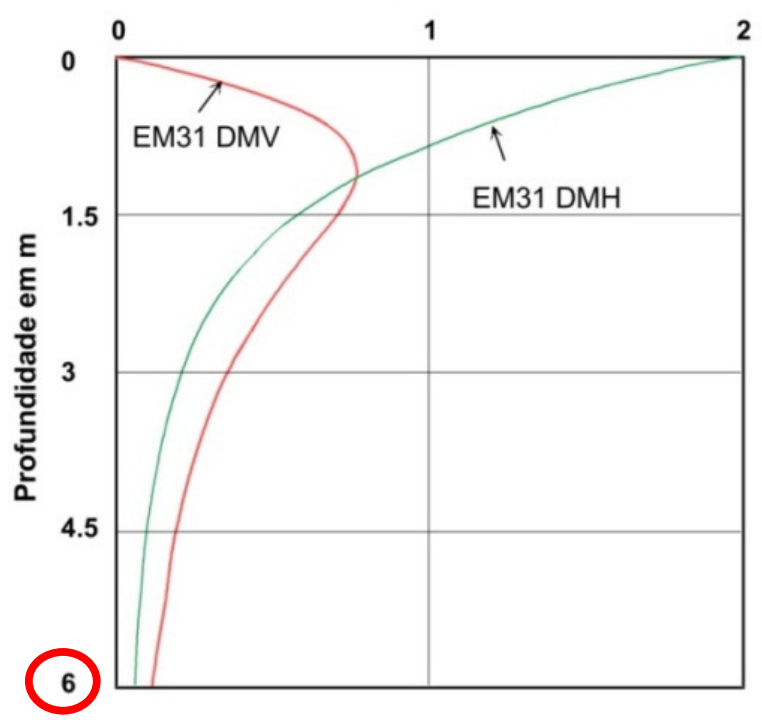

B

Resposta EM38

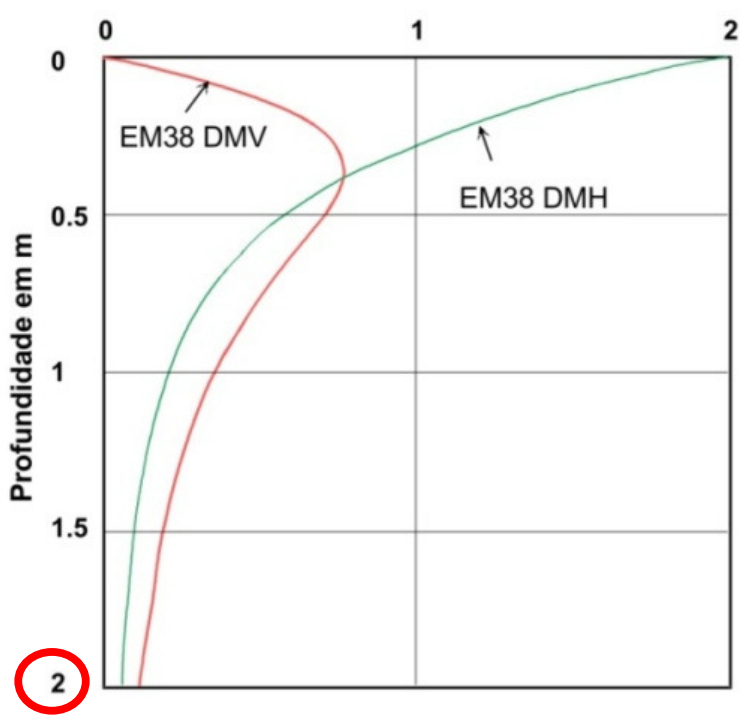

Figura 13 - Curvas de respostas teóricas dos aparelhos (A) EM31 e (B) EM38 (Geonics).

O EM38-MK2 possui um espaçamento entre bobinas de $1 \mathrm{~m}$ e frequência de indução de $14.6 \mathrm{kHz}$ (Foto $1 \mathrm{~B}$ e Figura $13 \mathrm{~B}$ ). Esse aparelho mede a condutividade elétrica aparente (CEa) do solo em profundidades teóricas de 0,75 m (DMH-Dipolo 
Magnético Horizontal), e 1,5 m (DMV-Dipolo Magnético Vertical). No EM31-MK2 a distância entre bobinas é maior, de 3,66 metros, e uma frequência de indução de 9,8 $\mathrm{kHz}$ (Foto $1 \mathrm{~A}$ e Figura $13 \mathrm{~A}$ ). Este aparelho aumenta a profundidade efetiva de prospecção para 6 metros de profundidade. Estas características dos aparelhos são complementares, e permitem um maior detalhamento da condutividade elétrica aparente do solo em função da profundidade (Figura 13 A e B).

Ambos os aparelhos possuem ligação por cabo a um sistema automático de aquisição de dados (data logger modelo DAS70-CX). O EM38 é acoplado a um GPS por um sistema Blutooth, que permite também obter automática e concomitantemente dados de latitude e de longitude. No caso do EM31, que não possui porta Blutooth, a aquisição de dados é feita separadamente, a cada segundo, pelo condutivímetro e pelo GPS, após ajustes dos relógios internos de cada um.

c) Aquisição e tratamento dos dados

Para identificar a variabilidade da CEa dos solos nas pequenas depressões fêz-se uma alta densidade de pontos georreferenciados.

$\mathrm{Na}$ Depressão Fechada os dados foram obtidos: (1) nas modalidades vertical e horizontal do aparelho EM38. Na modalidade vertical, o espaçamento aproximado da malha de pontos foi de $5 \times 5$ metros, e na horizontal de $5 \times 10$ metros; (2) na modalidade vertical com o EM31, as medidas foram tomadas a cada segundo, em um plano espiral saindo do centro da depressão em direção à sua borda, aumentando-se o raio em 5 metros a cada volta.

Na Depressão Aberta 2 as medidas de CEa foram: (1) na modalidade vertical com o EM38, em uma malha com espaçamento de $5 \times 5$ metros; (2) nas modalidades vertical e horizontal com o EM31, sendo que os pontos de medidas também seguiram um plano espiral idêntico ao descrito anteriormente.

Os tratamentos geoestatísticos com os dados foram feitos antes de utilizá-los para confecção dos mapas. O objetivo foi verificar se a densidade de pontos permitia expressar a variabilidade da CEa no espaço. Para isto, foram utilizadas técnicas de estudo de semivariogramas, uma ferramenta básica de suporte às técnicas de krigagem.

O método da Krigagem se baseia em dados dispostos em forma de tabelas, e suas posições geográficas. Ele é usado para estimar valores de variáveis nos pontos 
onde não foram medidas, e para isto, utiliza dados obtidos em pontos adjacentes (Pessoa, 2006). Esta técnica permite estimar valores de forma não tendenciosa, e com variância mínima (Gonçalves, 1997).

Por sua vez, o semivariograma representa, quantitativamente, a variação de um fenômeno regionalizado no espaço por meio de parâmetros como: alcance, patamar, efeito pepita e contribuição. Estes parâmetros indicam o nível de dependência entre duas variáveis no espaço. Em geral, a variabilidade aumenta quando a distância aumenta, ou seja, quanto mais afastados os pontos, menos eles estão correlacionados (Landim, 1998; Pessoa, 2006).

O estudo do semivariograma experimental visa o ajuste de um modelo pelo método dos mínimos quadrados, usado na interpolação de dados. No presente caso, ele possibilitou elaborar mapas de distribuição da condutividade elétrica aparente dos solos nas depressões.

d) Testes e qualidade dos dados

$O$ fato de nossa equipe de pesquisa ter adquirido recentemente os aparelhos geofísicos (EM38-MK2 e EM31-MK2) exigiu mais tempo para manuseá-los. Além disto, os novos modelos de aparelhos possuem sistemas automáticos de calibração. Por esses motivos, no decorrer deste trabalho foram feitos esforços no sentido de testar as respostas dos aparelhos, comparando-as a uma resposta teórica.

O teste pressupõe, de um lado, obtenção de valores de CEa pelo EM38 em um ponto dado no terreno, e de outro lado, o valor teórico do EM38 calculado a partir da espessura e profundidade dos diferentes horizontes, da resistividade média de cada horizonte, e da curva de resposta teórica estabelecida por McNeill (1980), que é dada pelo programa PCLoop 1.0, fornecido pela Geonics.

Os valores de CEa pela equação teórica são obtidos pela fórmula:

(a) $\quad S_{V}(Z)=\frac{4 Z}{\left(4 Z^{2}+1\right)^{(3 / 2)}}$

onde: $Z$ = profundidade teórica do EM38 na posição vertical $(\mathrm{cm})$;

$\mathrm{Sv}=$ condutividade elétrica $(\mu \mathrm{S} / \mathrm{cm})$. 
A resistividade é definida pela resistência que um material impõe à passagem de uma dada corrente elétrica, ou seja, é inversamente proporcional à condutividade elétrica.

As medidas de resistividade do solo foram feitas no Laboratório de Instrumentação Geofísica (Departamento de Geofísica, IAG/USP - São Paulo). O modelo de aparelho utilizado é descrito por Abu-Hassanein et al. (1996). Ele é composto de um tubo de PCV, no qual se colocam amostras de solo, com as extremidades fechadas por placas de alumínio. As extremidades e o centro do tubo são providos de eletrôdos de cobre, sendo o primeiro para emissão de correntes elétricas, e o segundo para medir o potencial (Foto 2). A Figura 14 mostra o esquema desses aparelhos.

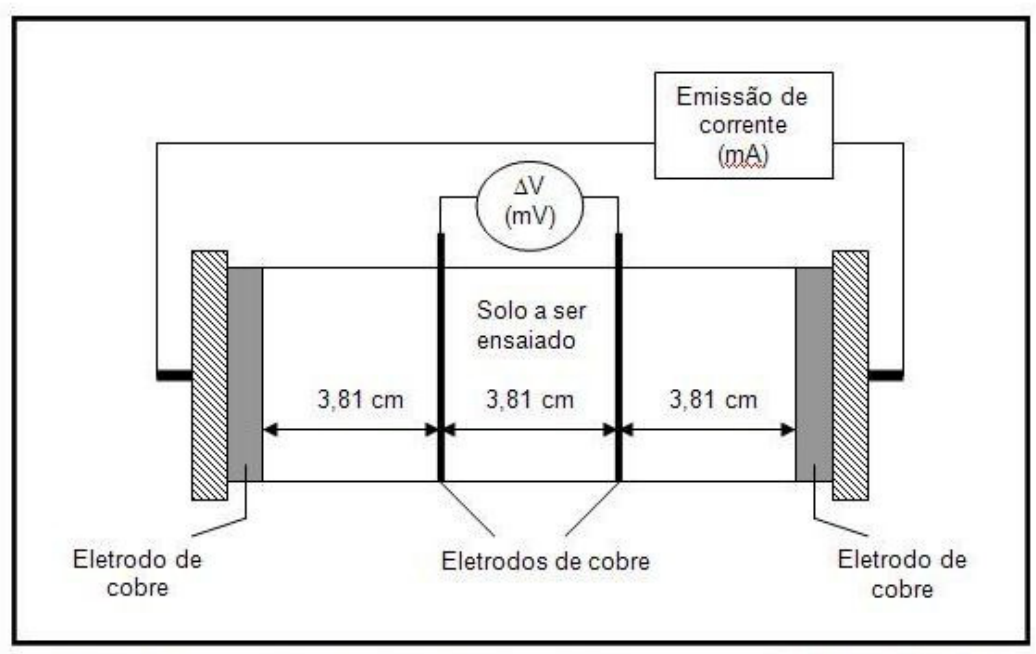

Figura 14 - Modelo de aparelho para medir a resistividade do solo (Abu-Hassanein et al.,1996).

Considerando-se os parâmetros do cilindro, com o diâmetro e espaçamento entre eletrôdos, a resistividade do solo pode ser calculada pela fórmula:

$$
\rho=R \cdot \frac{S}{L}
$$

onde:

$\rho=$ resistividade elétrica (ohm.m)

$\mathrm{R}=$ resistência elétrica (ohm)

$\mathrm{S}=$ área da seção transversal do cilindro $\left(\mathrm{m}^{2}\right)$

$\mathrm{L}=$ comprimento do cilindro $(\mathrm{m})$ 


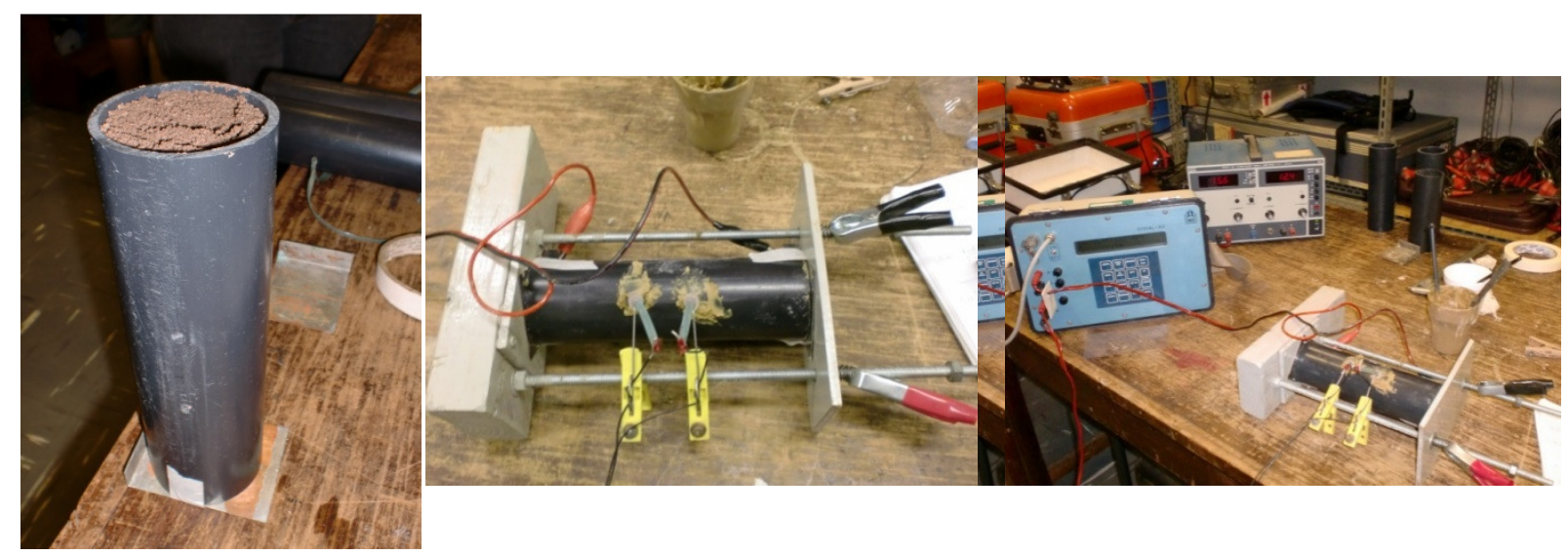

Foto 2 - Aparelho utilizado no laboratório para medir a resistividade do solo.

As medidas de resistividade foram feitas em amostras coletadas nos horizontes (1a), (2), (6) e (7) da Depressão Aberta 2; e (1), (2), (1c) e (6) da Depressão Fechada. Ressalta-se que as amostras dos horizontes (1) e (2) da Depressão Fechada foram misturadas, obtendo-se um valor médio da resistividade entre esses dois horizontes.

II -Métodos diretos

A identificação das organizações verticais e laterais dos horizontes contribui para esclarecer as etapas de formação e evolução da cobertura pedológica, e pode colocar em evidência possíveis distúrbios atuais e sub-atuais na paisagem. Daí a relevância da escolha dos métodos diretos de observação dos solos.

a) Método

A Análise Estrutural da Cobertura Pedológica (Boulet et al., 1982) norteou os estudos de solos, e as descrições das características morfológicas apoiaram-se no Manual da EMBRAPA (1997).

Os trabalhos de Bocquier (1971) e de Boulet (1978) mostraram que muitas coberturas pedológicas se desenvolvem por transferências laterais de elementos, e suas redistribuições ao longo de vertentes. Por isto, privilegiaram observações de 
solos em topossequências que partem do topo do interflúvio, e seguem a linha de maior declive até o fundo do vale.

Esse procedimento se inicia por sequências de tradagens para reconhecimento geral da cobertura pedológica. Se houver diferenciações de horizontes entre uma tradagem e outra, faz-se uma tradagem intermediária para localizar como e onde elas aparecem e/ou desaparecem. Nos pontos onde foram identificadas essas diferenciações, abrem-se trincheiras. O passo seguinte é a análise tridimensional que tem por objetivo reconstituir, por aproximações geométricas, a organização espacial da cobertura pedológica na escala da bacia elementar, ou de uma parte representativa desta (Boulet, 1998).

Nas sequências de tradagens nos solos das áreas de estudo, os nomes dados aos horizontes basearam-se nas descrições das características morfológicas feitas em campo, principalmente cor e textura.

As variações topográficas nas áreas de estudo são muito pequenas, e não existem cartas topográficas em grande escala da região. Por isto foi necessário fazer um levantamento topográfico da área de cada pequena depressão. O levantamento topográfico foi feito com um nível de precisão modelo HV101 (FG-L3 Rotation Laser, da "Spectra Precision Laser"), e com um GPS (GARMIN GPS map60). As medidas foram feitas em uma malha irregular de pontos georeferenciados. Com o programa Surfer transformou-se os dados obtidos em cartas topográficas.

b) Localização das sequências

Nas Depressões Aberta 1 (DA1) e na Fechada (DF) as sequências foram posicionadas de uma extremidade a outra da depressão. No centro da DA1 foi aberta uma trincheira (Figura 16-1), e as descrições dos solos foram completadas pelas tradagens $\mathrm{S} 1$ a $\mathrm{S} 5$, com 95 metros de comprimento e um desnível de 1,10 metros. Na DF a sequência G1 a G9 foi complementada por mais duas tradagens isoladas (GA e GB), nos pontos com os maiores valores de CEa (Figura 15). A sequência possui 110 metros e desnível de 0,80 metros, do centro a borda da depressão. 


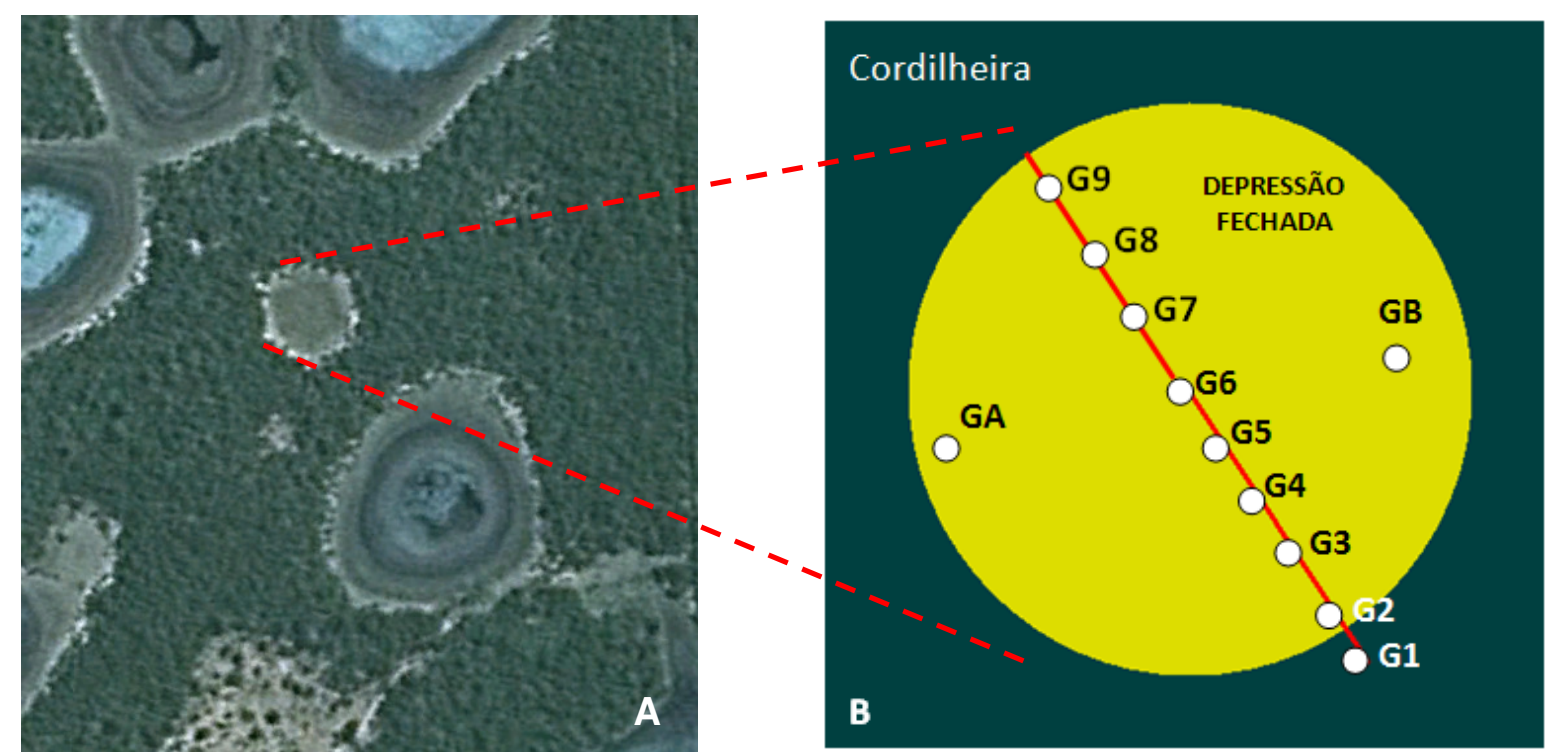

Figura 15 - (A) Localização da Depressão Fechada (Google Earth, 2010) e (B) a sequência de solos.
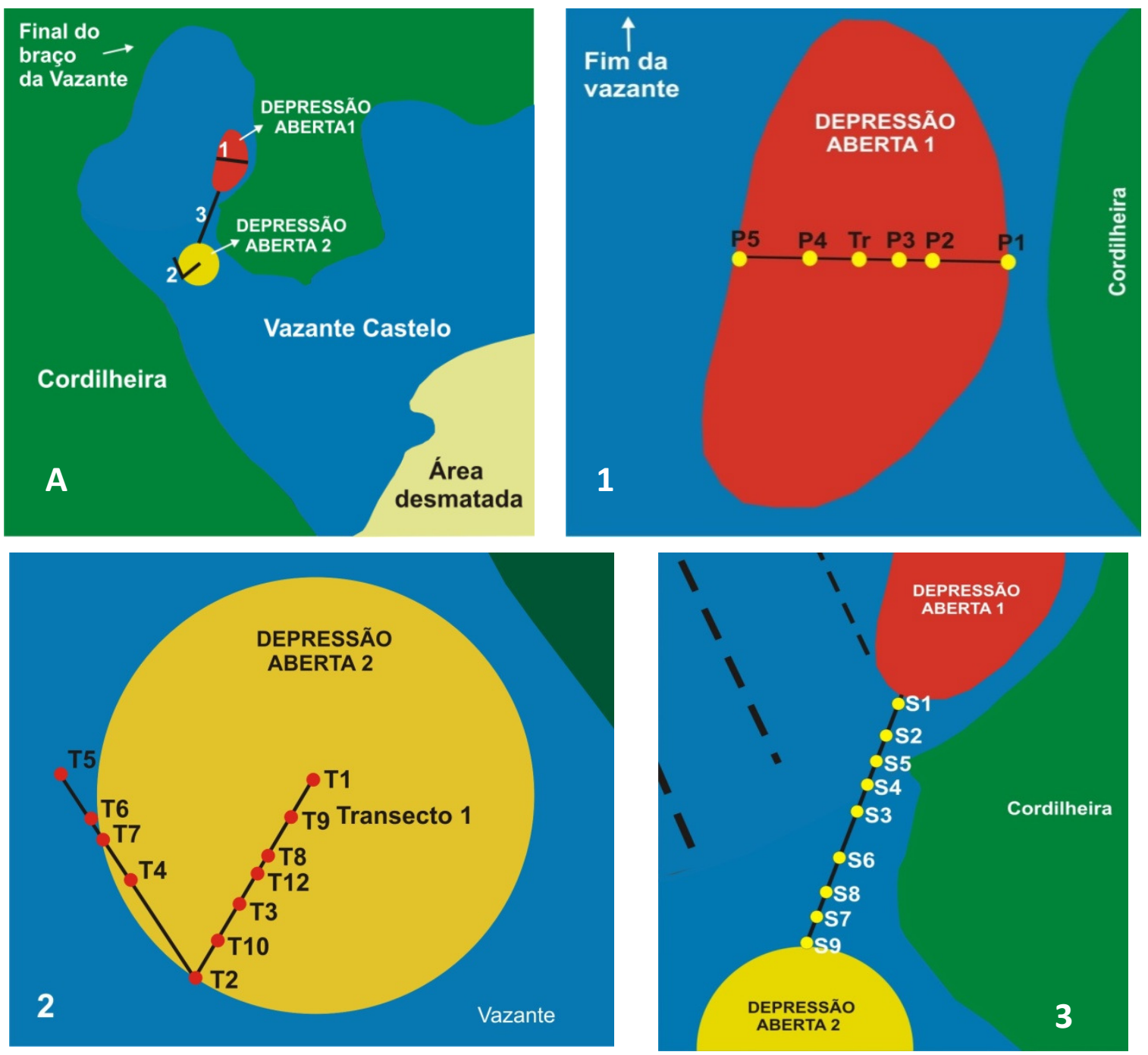

Figura 16 - (A) Localização das sequências de solos: (1) na Depressão Aberta 1; (2) na Depressão Aberta 2; (3) entre as Depressões Abertas 1 e 2. 
Na Depressão Aberta 2, a sequência T1 a T2 se inicia no centro da depressão e vai até uma de suas extremidades, de onde se prolonga lateralmente entre T2 e T5 (Figura 16-2). O desnível entre o centro da depressão até sua borda é de 1 metro, e comprimento total de 37 metros.

Finalmente, posicionou-se uma sequência ligando as Depressões Abertas $1 \mathrm{e}$ 2. Ela se inicia na borda da DA1 e vai até a borda da DA2, entre os pontos P1 e P9 (Figura 16-3), e comprimento de 90 metros.

\section{C) Caracterização dos constituintes sólidos}

Os solos são constituídos por partículas minerais, materiais orgânicos, água e ar. O tamanho das partículas influem nas propriedades físicas e químicas do solo, como alguns tipos de poros, textura, permeabilidade à água, capacidade de trocas, dentre outros. Para avaliar a textura do solo, recorreu-se à análise granulométrica.

\section{I - Granulometria}

A análise granulométrica permite quantificar a proporção das diferentes frações de tamanho de partículas do solo, isto é, areia, silte e argila. Os métodos utilizados foram o da pipetagem e do peneiramento, segundo os Procedimentos Analíticos do Laboratório de Sedimentologia (2004), LABSED (Depto de Geologia Sedimentar e Ambiental - IGC -USP/SP). Esse procedimento ocorre em diversas etapas:

(i) pré-tratamento de remoção da matéria orgânica das amostras de solo, para eliminar os agentes que causam floculação, e auxiliar na dispersão dos colóides. Essa remoção é feita pela adição de água oxigenada $\left(\mathrm{H}_{2} \mathrm{O}_{2}\right) 50$ v. em 60 gramas de solo, que é em seguida colocada sobre uma placa aquecida a $50^{\circ} \mathrm{C}$ até cessar a reação de efervescência (Figura 3). A amostra é secada na estufa antes de ser pesada em balança. A diferença entre o peso inicial e o final equivale a quantidade de matéria orgânica contida na amostra. 

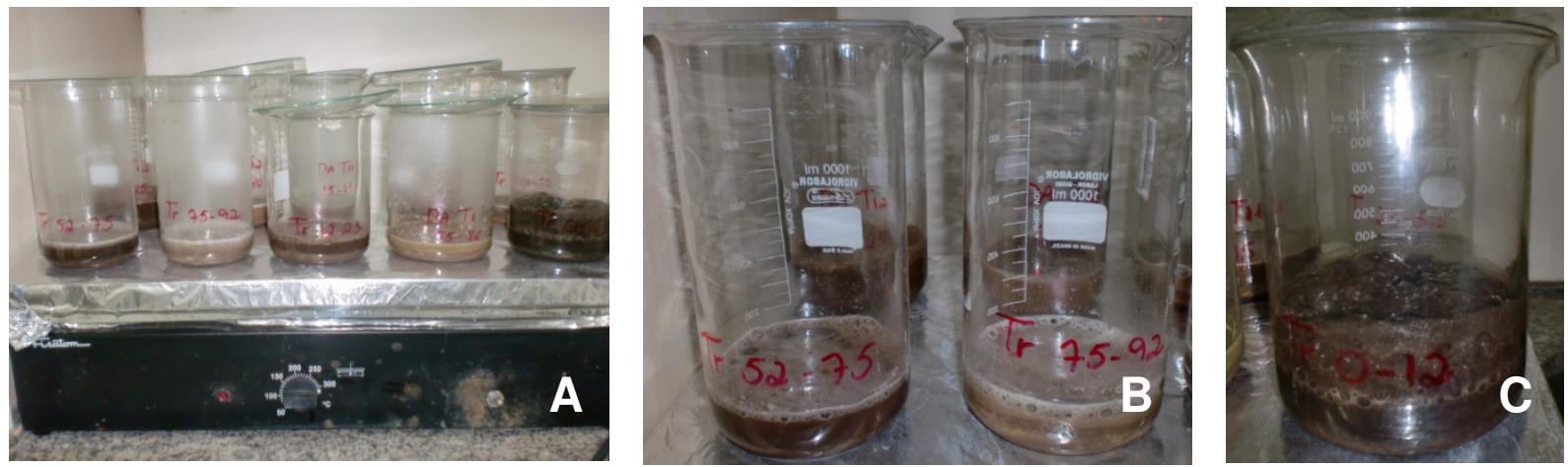

Foto 3 - (A) Amostras de solos com água oxigenada sobre uma placa aquecida para remoção de $\mathrm{MO}$. Detalhe das amostras em efervescência após acrescentar água oxigenada $(B)$ e $(C)$.

(ii) procedimento da análise granulométrica feita em duas etapas:

$1^{\circ}$ ) de pipetagem, para separação de partículas com tamanhos menores que 0,062 (silte e argila). O método se baseia no tempo de decantação de partículas em meio fluído, segundo a lei de Stokes (Figura 4 A). O princípio é regido pelo fato de que em líquido estacionário as partículas sem comportamento coloidal $(d>0,5 \mu m)$, decantam com velocidade constante, em função de seu raio, forma, densidade, textura superficial, e da densidade e viscosidade do fluído;

$2^{\circ}$ ) de peneiramento (Figura 4 B) para separação de partículas com tamanhos entre 2 e 0,062 mm (areia), e que se divide em duas fases: a) uma após a pipetagem, de elutriação, destinada à lavagem das amostras para remoção dos finos (silte, argila); b) outra, após secagem em estufa do material lavado, destinada ao peneiramento propriamente dito.
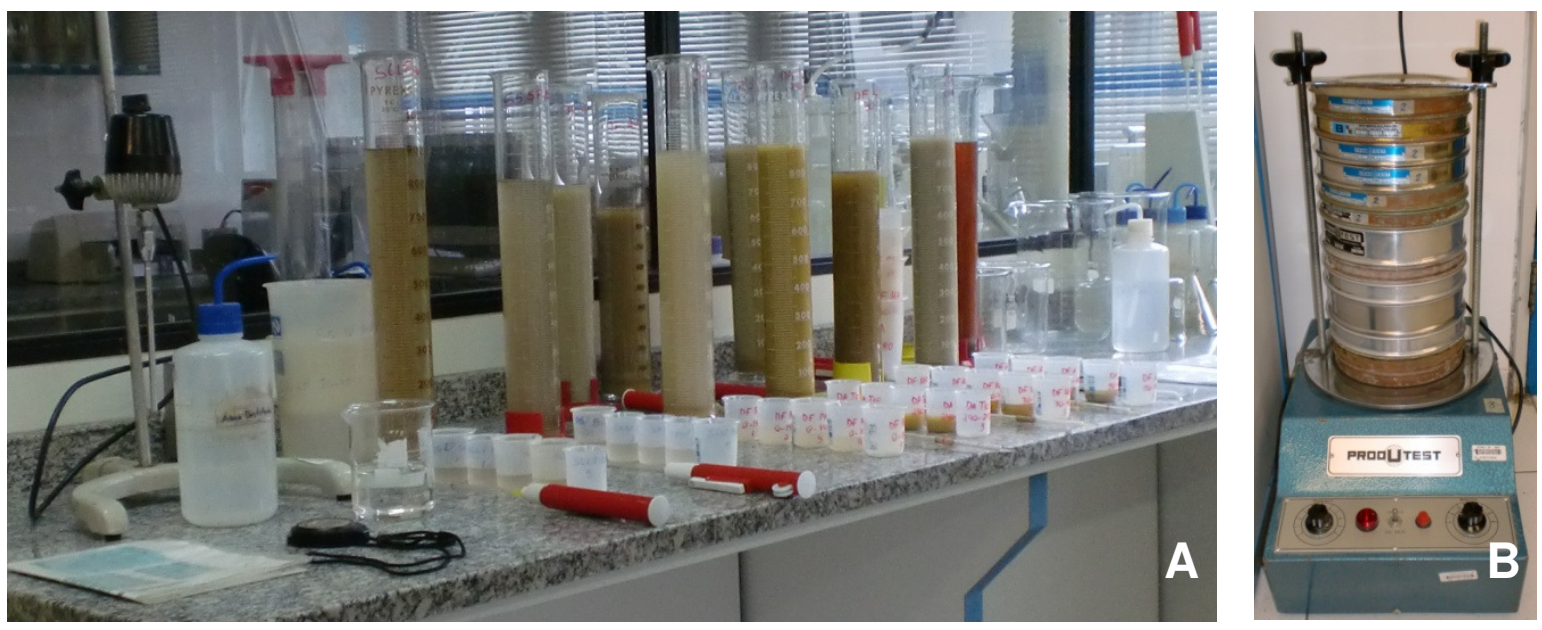

Foto 4 - (A) Pipetagem; (B) Peneiramento. 
A Tabela 1 apresenta as amostras de solos que foram analisadas.

Tabela 1 - Relação das amostras de solos das três pequenas depressões e suas respectivas análises.

\begin{tabular}{|c|c|c|c|}
\hline $\begin{array}{c}\text { AMOSTRAS } \\
\text { Profundidade }(\mathrm{cm})\end{array}$ & $\begin{array}{c}\text { ANÁLISE } \\
\text { GRANULOM. }\end{array}$ & $\begin{array}{c}\text { EXTRAÇÃO DE } \\
\text { M.O. }\end{array}$ & $\begin{array}{l}\text { LÂMINAS } \\
\text { DE ARGILA }\end{array}$ \\
\hline \multicolumn{4}{|c|}{$\operatorname{Tr}$ (DA1) - Trincheira Depressão Aberta 1} \\
\hline$(\operatorname{Tr}) 0-12$ & $\mathrm{X}$ & $\mathrm{X}$ & \\
\hline $12-23$ & $\mathrm{x}$ & $\mathrm{x}$ & \\
\hline $23-52$ & $\mathrm{x}$ & $\mathrm{X}$ & \\
\hline $52-75$ & $\mathrm{x}$ & $\mathrm{x}$ & \\
\hline $75-92$ & $\mathrm{x}$ & $\mathrm{x}$ & \\
\hline $92-125$ & $\mathrm{x}$ & & \\
\hline $125-185$ (fase verde) & $\mathrm{x}$ & & $\mathrm{X}$ \\
\hline $126-185$ (fase cinza) & $\mathrm{x}$ & & $\mathrm{x}$ \\
\hline $127-185$ (fase ocre) & $\mathrm{x}$ & & $\mathrm{X}$ \\
\hline $180-220$ & $\mathrm{X}$ & & \\
\hline 220 & $\mathrm{X}$ & & \\
\hline $290-320$ & $\mathrm{X}$ & & \\
\hline $340-360$ & $\mathrm{X}$ & & \\
\hline \multicolumn{4}{|c|}{ DA2 - Depressão Aberta $2(\mathrm{~cm})$} \\
\hline (T10) 0 - 30 & $\mathrm{X}$ & $\mathrm{X}$ & \\
\hline $30-70$ & $\mathrm{X}$ & $\mathrm{X}$ & \\
\hline $70-75$ & $x$ & $x$ & \\
\hline $75-98$ & $x$ & $x$ & \\
\hline $120-145$ & $x$ & & $x$ \\
\hline $175-200$ & $x$ & & $x$ \\
\hline $230-240$ & $x$ & & $x$ \\
\hline $240-295$ & $\mathrm{x}$ & & $\mathrm{x}$ \\
\hline (T3) 60 - 70 & $\mathrm{x}$ & $\mathrm{x}$ & \\
\hline $70-80$ & $\mathrm{x}$ & $\mathrm{x}$ & \\
\hline (T12) $0-25$ & $\mathrm{x}$ & $\mathrm{x}$ & \\
\hline $35-80$ & $\mathrm{x}$ & $\mathrm{x}$ & \\
\hline $80-105$ & $\mathrm{x}$ & $\mathrm{x}$ & \\
\hline $120-160$ & $\mathrm{x}$ & & $\mathrm{x}$ \\
\hline (T8) $230-250$ & $\mathrm{x}$ & & $\mathrm{x}$ \\
\hline (T1) $0-15$ & $x$ & $x$ & \\
\hline $15-45$ & $\mathrm{X}$ & $\mathrm{x}$ & \\
\hline $55-86$ & $x$ & $x$ & \\
\hline $120-140$ & $x$ & & $x$ \\
\hline $200-220$ & $\mathrm{X}$ & & $\mathrm{X}$ \\
\hline \multicolumn{4}{|c|}{ DF - Depressão Fechada (cm) } \\
\hline (PA) $0-140$ & $x$ & & \\
\hline (HA) $30-45$ & $x$ & & \\
\hline (A) $0-180$ & $x$ & & \\
\hline (B) $190-280$ & $x$ & & $\mathrm{X}$ \\
\hline
\end{tabular}


A Tabela 2 apresenta os intervalos adotados neste trabalho.

Tabela 2 - Intervalos de tamanhos de partículas.

\begin{tabular}{|c|c|c|c|}
\hline \multicolumn{4}{|c|}{ INTERVALOS DAS PARTÍCULAS (mm) } \\
\hline \multicolumn{2}{|c|}{ Peneiramento } & \multicolumn{2}{|c|}{ Pipetagem } \\
\hline $2,000-1,410$ & Areia muito grossa & $0,062-0,031$ & Silte grosso \\
\hline $1,410-1,000$ & Areia muito grossa & $0,031-0,016$ & Silte médio \\
\hline $1,000-0,707$ & Areia grossa & $0,016-0,008$ & Silte fino \\
\hline $0,707-0,500$ & Areia grossa & $0,008-0,004$ & Silte muito fino \\
\hline $0,500-0,354$ & Areia média & $<0,004$ & Argila \\
\hline $0,354-0,250$ & Areia média & & \\
\hline $0,250-0,177$ & Areia fina & & \\
\hline $0,177-0,125$ & Areia fina & & \\
\hline $0,125-0,088$ & Areia muito fina & & \\
\hline $0,088-0,062$ & Areia muito fina & & \\
\hline$<0,062$ (fundo) & Silte/Argila & & \\
\hline
\end{tabular}

As amostras dos horizontes profundos, cuja textura descrita no campo é argilosa, foram selecionadas para confecção de lâminas de argila para análises por difratometria. Essas lâminas foram preparadas durante a pipetagem, após coleta da última alíquota de argila para análise granulométrica, coletou-se uma amostra adicional em uma lâmina de vidro de $25 \times 25 \mathrm{~mm}$ posicionada em um recipiente, para secar em temperatura ambiente.

\section{II - Difratometria}

A análise de lâminas de argila por difratometria de raio $X$ foi utilizada para identificar a mineralogia da fração argila dos solos estudados.

Princípio do método: os raios $X$ são radiações eletromagnéticas que, como tais, podem ser polarizadas, difratadas, refratadas e refletidas. Quando um feixe de raio $X$ atravessa um material absorvente, há descontinuidades na absorção da radiação. Os comprimentos de onda correspondentes a essas descontinuidades são também características de cada um dos elementos químicos que o compõem. Ao se liberar ondas eletromagnéticas, estas excitam os elétrons contidos nos átomos, que compõem os cristais. Esses elétrons tornam-se uma fonte de ondas eletromagnéticas de mesma frequência e comprimento de onda que os raios-x 
incidentes, isto é, os elétrons dispersam o feixe incidente e se combinam difratando a radiação $x$. A intensidade da dispersão depende do número de elétrons no átomo, e da direção das ondas. Assim, a posição das reflexões e as intensidades relativas, que são dependentes, respectivamente, do cristal e do arranjo dos átomos, são características da estrutura cristalina do mineral, tornando possível a sua identificação (Formoso, 1984).

Essas análises foram feitas no Laboratório de Difração de Raios $X$ do Depto de Mineralogia e Geotectônica (IGC-USP/SP), com o aparelho Brucker Siemens, modelo D5000, operando em $40 \mathrm{Kw}$ e $40 \mathrm{~m} \AA$ (miliamper) com tubo de cobre Ka.

A passagem das lâminas no aparelho foi feita em três situações diferentes para identificar grupos de argilo-minerais: $1^{\circ}$ ) da lâmina em estado natural; $2^{\circ}$ ) da lâmina tratada com Etileno Glicol, para identificar argilo-minerais com propriedades expansivas; $3^{\circ}$ ) e lâmina após aquecimento a $500^{\circ} \mathrm{C}$ durante 4 horas em forno a fim de eliminar água, responsável por modificações estruturais passíveis de detecção no difratograma de raios $X$.

\section{D) Monitoramento e características das águas}

A circulação de água nos solos é de extrema importância para entender as reações físico-químicas que ali ocorrem, mas também o funcionamento hídrico do local onde o solo se desenvolve. A área de estudo é submetida a cheias periódicas, que afetam o nível do lençol freático, que consequentemente varia em função das oscilações entre períodos de cheia e de seca.

Assim, um monitoramento automático das oscilações do nível da água do lençol freático, e a identificação das características físico-químicas dessas águas são fundamentais para entender o funcionamento hídrico das pequenas depressões. Para isto, instalaram-se piezômetros e coletores de água do lençol freático. 


\section{I- Piezômetria}

Os piezômetros foram confeccionados com dois canos de PVC, de 1 e 2 polegadas, o de 1 colocado no de 2, e rachurados na extremidade inferior aberta posicionada dentro do solo. Entre os dois canos coloca-se pedregulhos para que a água possa fluir. Com ajuda de um trado manual os piezômetros são introduzidos a profundidades variadas, até atingir o nível da água do lençol freático (Sakamoto et al., 2000). Esta operação foi feita no período seco (setembro, 2010), quando o nível do lençol freático é mais baixo (Figura 17). A leitura do nível da água é feita automaticamente por uma sonda tipo Mini Diver ${ }^{\circledR}$ de 3 em 3 horas (Foto $5 \mathrm{~A}$ ).

$\mathrm{Na}$ área de estudo foram instalados apenas 2 piezômetros, um (P1) na Baía, no limite da água com o capim-de-burro, outro (P2) no centro da Depressão Fechada (Fotos 5 B e C). Essas duas unidades da paisagem encontram-se separadas por uma cordilheira.

A diferença topográfica é de $0,85 \mathrm{~m}$ entre a superficie do solo no centro da DF (P2), e a superfície do solo onde está instalado o P1 na baía.

O período de monitoramento foi de 08/10/2010 a 03/10/2011.
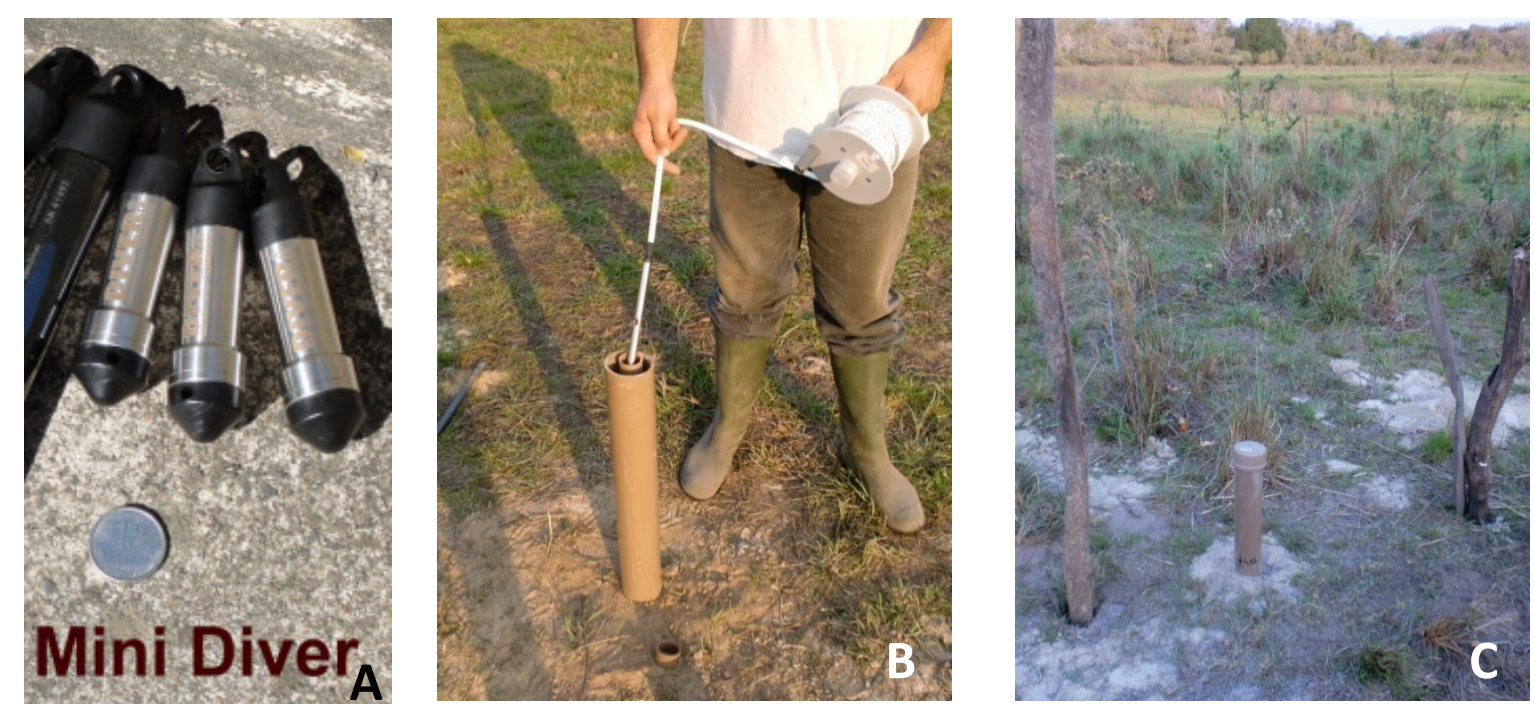

Foto 5 - (A) Sondas tipo Mini Diver (B; (B) piezômetro instalado no centro da Depressão Fechada; (C) e na Baía no limite capim rabo-de-burro - água. 


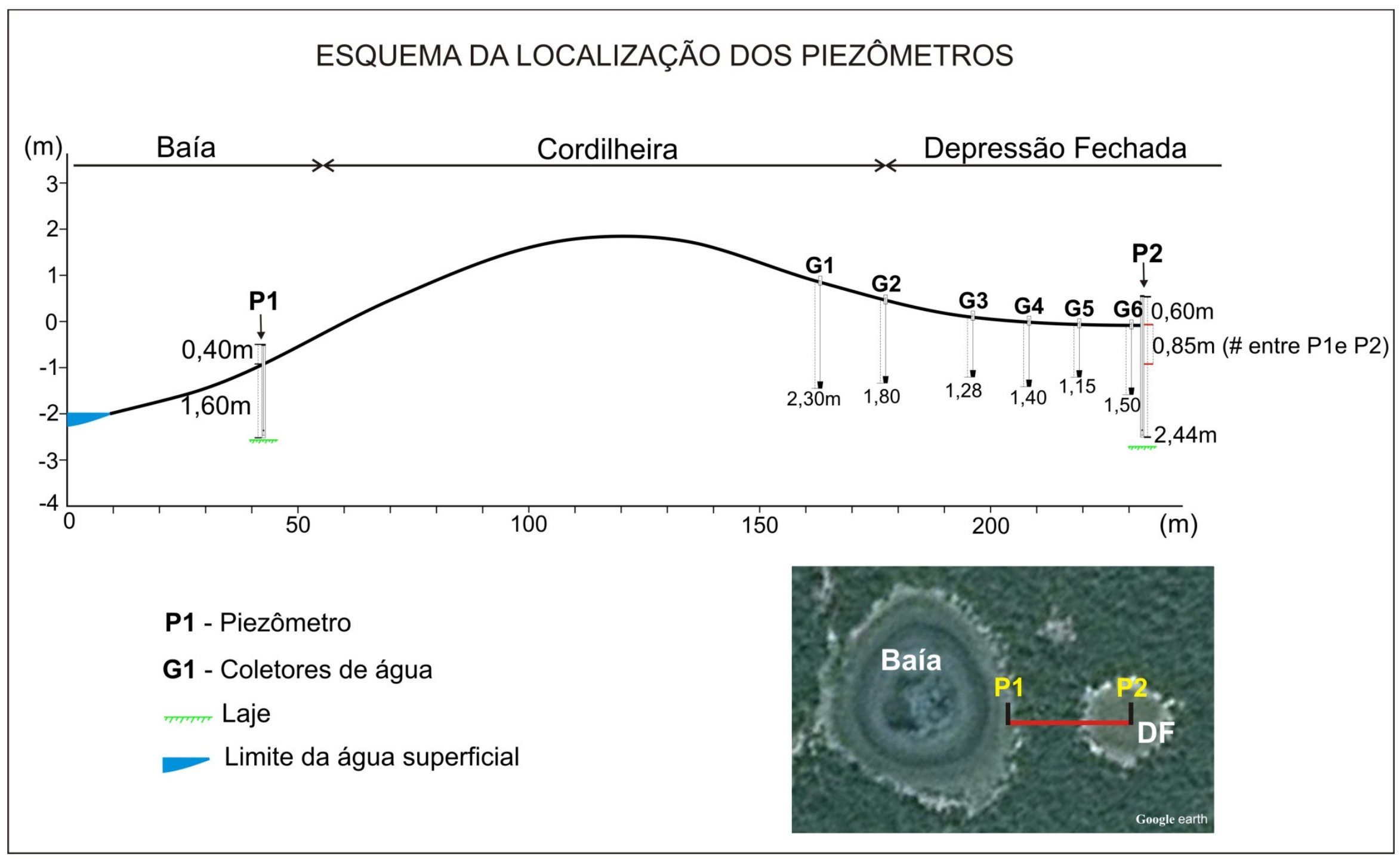

Figura 17 - Localização: (a) Piezômetros: (P1) na Baía, (P2) no centro da Depressão Fechada; (b) dos coletores de água do lençol: (G1) ao (G6). 


\section{II - Coletores de água do lençol freático}

Os coletores de água do lençol freático foram instalados nos furos feitos com trado, para descrever os solos da Depressão Fechada.

O coletor é feito com um recipiente de polietileno com tampa, no qual se fazem furos na parte inferior, e um na parte superior por onde passa um capilar de polietileno com diâmetro de $2 \mathrm{~mm}$. O recipiente é envolvido por um tecido cuja trama, muito fina, deixa passar a água, mas não os sedimentos. O capilar se estende do coletor alojado no lençol até a superfície do solo, onde é protegido por uma tampa de PVC (Foto 6). A coleta de água é feita por sucção, com uma bomba de 0-80 kPa, modelo UMS (VPS, Alemanha).

Os parâmetros físico-químicos das águas medidos diretamente no campo são: $\mathrm{CE}$, temperatura, $\mathrm{pH}$ e redox. Para isto, utilizou-se um condutivímetro (modelo HI 9835), que também mede a temperatura, um pHmêtro (modelo HI 95143 ) e um Ehmêtro (modelo HI 98150), todos da marca HANNA Instruments. Também foram coletadas amostras de águas para análises químicas em laboratório.

As medidas desses parâmetros foram feitas em diferentes momentos no período de 24/05/2010 a 06/10/2011.

Nas Depressões Abertas 1 e 2 foram realizadas medidas in situ das variáveis físico-químicas das águas. Na primeira, as medidas foram feitas nas águas superficiais e do lençol freático, no centro da depressão; e na segunda, as medidas foram feitas nas águas onde aflorou o lençol freático pelas tradagens.
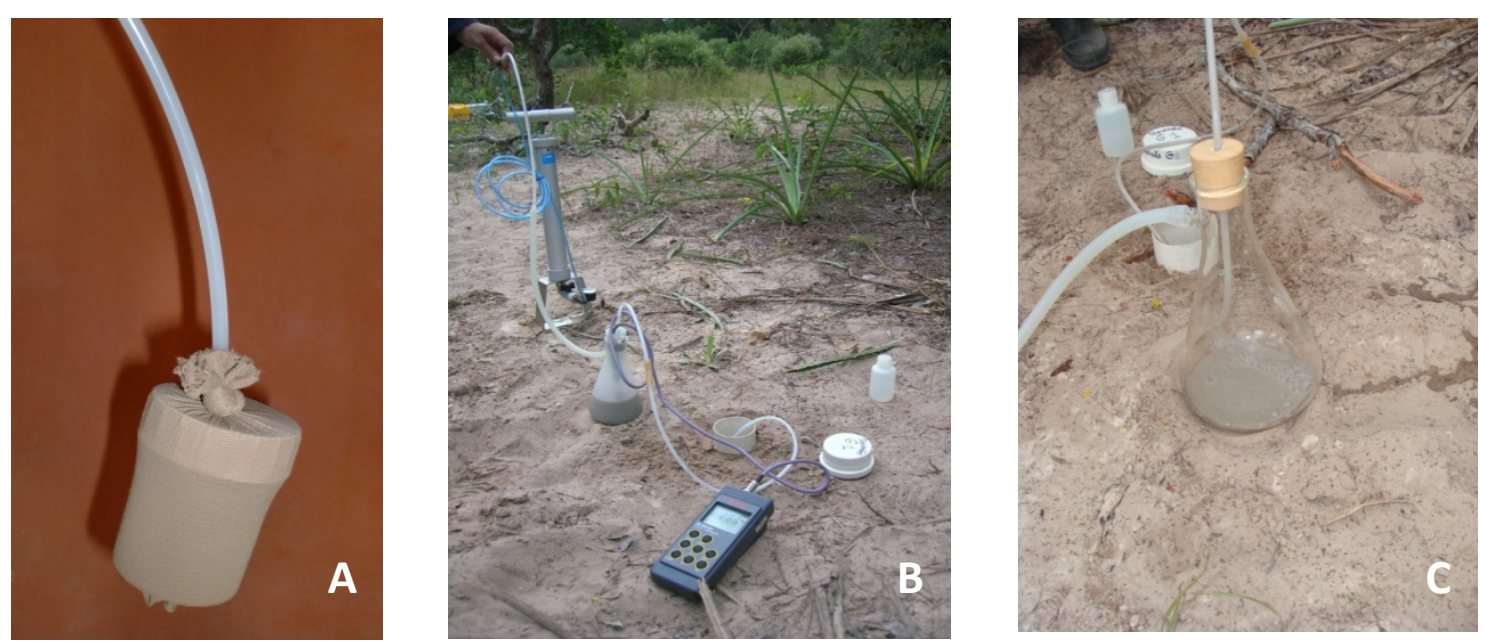

Foto 6 - (A) Coletor de água; (B) e (C) coleta de água do lençol com o auxilio da bomba de sucção. 


\section{4 - RESULTADOS}

A apresentação dos resultados segue a mesma ordem da apresentação dos métodos.

\section{1- MAPA FISIOGRÁFICO}

\section{A) Descrição da área mapeada}

O mapa da Figura 18 apresenta as principais unidades fisiográficas identificadas no corte dessa porção sul da Nhecolândia.

Em primeiro lugar, destaca-se a Vazante Castelo por sua extensão entre cordilheiras, da qual difere pela cobertura vegetal de gramíneas. Ela atravessa o mapa de N-NE a S, e apresenta limites bem nítidos, cujos contornos são mamilados, palmados a digitados (Bullock et al., 1985 apud Castro, 2008). Esta vazante é formada por dois braços a montante, um na direção NE-SW, e o outro, denominado Castelinho, na direção N-S, que ao se juntarem tomam a direção única N-S até deságuar, de forma espraiada, no rio Negro. Este rio se caracteriza por trechos meândricos e outros mais retílineos, e meandros abandonados na planície aluvial.

A área delimitada pelo corte apresenta uma grande quantidade de lagoas. Nota-se que no quadrante SE há um maior adensamento de lagoas com tamanhos irregulares, cujas formas predominantes são ameboidal a digitada, e alongada a subarredondada. No quadrante NW, ao contrário, as lagoas são mais individualizadas, e formas predominantes alongada, subarredondada a arredondada, e em menor número ameboidal. Na porção inferior do quadrante SW elas também são mais espaçadas, e formas alongadas a arredondadas, e na porção superior, mais próximas umas das outras e formas ameboidal a subarredondada. No quadrante NE, entre os dois braços da Vazante Castelo, há um predomínio de lagoas com forma ameboidal e subarredondada.

Em conjunto, as lagoas apresentam um certo alinhamento na direção NE-SW, mais nítido nos quadrantes NW, SW e NE.

As lagoas foram agrupadas segundo suas características morfológicas, isto é: 1) lagoas com praia; 2) lagoas salinas; 3) lagoas com diferentes zoneamentos de vegetação e; 4) lagoas com zoneamento anelar. 
Mapa de distribuição das principais unidades da paisagem da Nhecolândia - Pantanal/MS

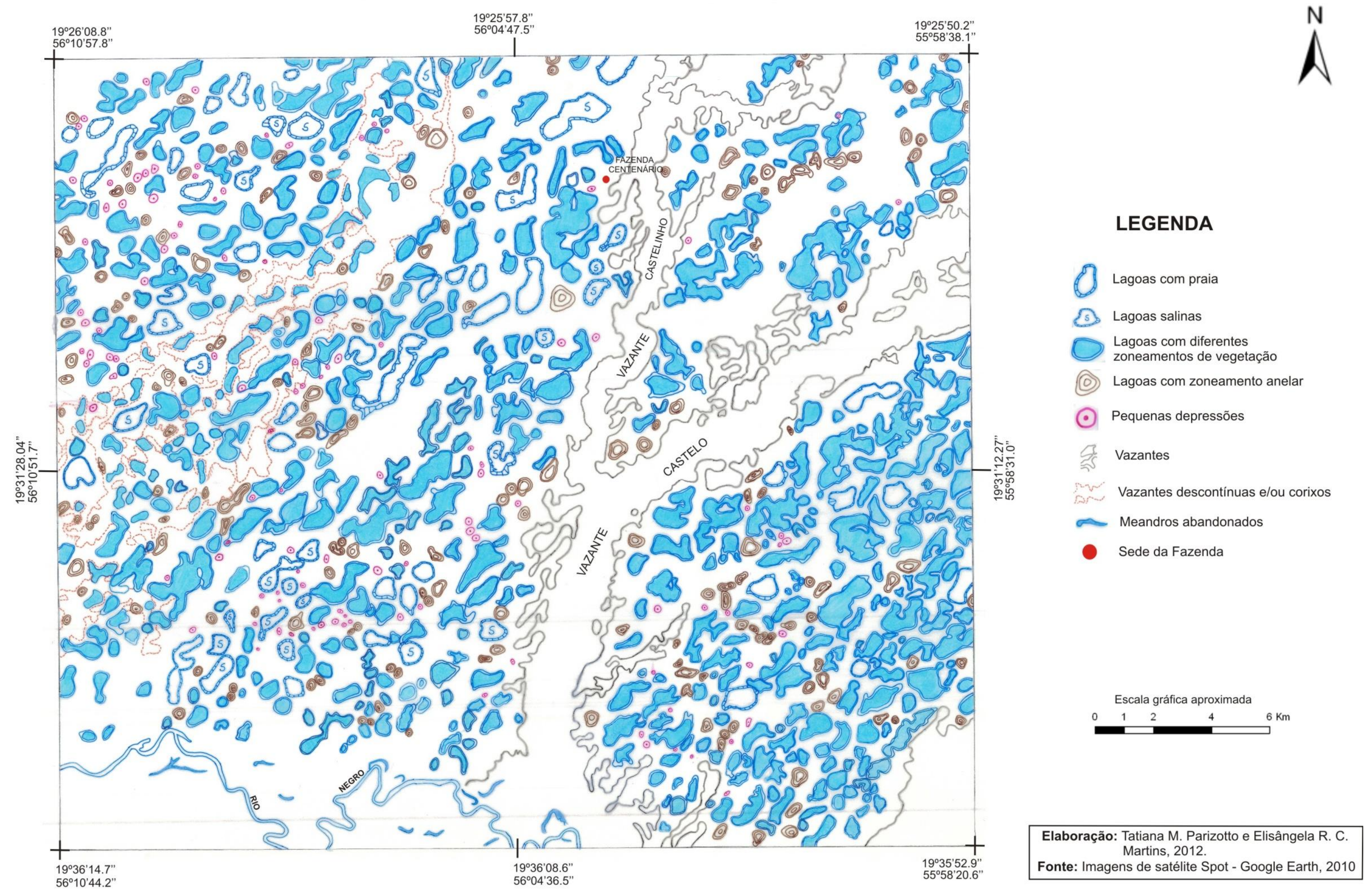

Figura 18 - Mapa com a distribuição das principais unidades de paisagem em uma porção ao sul da Nhecolândia. 
A unidade "lagoas com diferentes zoneamentos de vegetação" é a mais frequente, e predomina em relação às outras unidades mapeadas. $\mathrm{Na}$ imagem, esses zoneamentos se distinguem por diferentes tons de azul, do bem claro para o escuro, passando por cinzas azulados, esverdeados e avermelhados. No campo constatou-se que esses zoneamentos correspondem à cobertura vegetal de médio a pequeno porte, mas sobretudo diferentes tipos de vegetação aquática. Elas são circundadas ou não por cordilheiras, e muitas vezes aparecem alinhadas e interconectadas por corixos, com diferentes tamanhos e formas que variam de ameboidal a alongada e subarredondada.

As unidades "lagoas com praia" e "lagoas salinas" aparecem em menor proporção, apesar de frequentes na paisagem. Elas se caracterizam por uma praia branca que as contornam. O conjunto de lagoas com praia foi dividido em duas unidades, pois se reservou a notação "salinas", destacadas no mapa por um "S", somente às lagoas repertoriadas no campo por medidas de condutividade elétrica (CE). Geralmente, as salinas têm formas arredondadas e alongadas com tamanhos variados, e aparecem circundadas por cordilheiras, sem conexão aparente com a rede de drenagem, rios e vazantes. As praias que as circundam apresentam solo arenoso, sem vegetação, exceto gramíneas restrita e localmente.

A unidade "lagoas com zoneamento anelar" também são muito frequentes, e tamanho menor que das outras lagoas. Elas aparecem no interior de vazantes e cordilheiras, com formas arredondadas a alongadas, e zoneamentos anelares concêntricos nítidos dados pela umidade mas também por diferentes tipos de vegetação.

As vazantes descontínuas e/ou corixos são áreas que se distinguem por uma coloração mais clara, com contornos semelhantes aos da Vazante Castelo.

\section{B) Unidade "pequenas depressões"}

O mapa fisiográfico tem uma área total de $403 \mathrm{Km}^{2}$, na qual aparecem 111 pequenas depressões isoladas. Apenas no quadrante onde se localizam as pequenas depressões estudadas neste trabalho, nas coordenadas 19 '31'28,04" a $19^{\circ} 36^{\prime} 06,6^{\prime \prime}$ S e $56^{\circ} 10^{\prime} 51,7^{\prime \prime}$ a $56^{\circ} 04^{\prime} 36,5^{\prime \prime} \mathrm{W}$, com uma área total de $111 \mathrm{Km}^{2}$, contou-se 38 exemplares. As áreas dessas 38 pequenas depressões variam de 
1.296 a $21,7 \mathrm{mil} \mathrm{m}^{2}$, com uma média em torno de $7 \mathrm{mil} \mathrm{m}^{2}$. Isto mostra que essa unidade é representativa dessa porção sul da Nhecolândia.

No geral, nota-se que a distribuição dessa unidade é irregular, com maior número nos quadrantes SW e NW, e menor nos quadrantes NE. A forma é predominantemente arredondada e/ou ligeiramente oval, e tamanho pequeno em relação ao de todas as outras lagoas. Elas aparecem em três situações diferentes: 1) dentro de vazantes com forma circular ou oval, e cor sombreada com contorno esbranquiçado; 2) dentro da cordilheira, com forma arredondada, cor cinza esverdeado e textura menos rugosa que o entorno; e 3) como apêndices de qualquer tipo de lagoa, e forma arredondada.

\section{2 - TOPOGRAFIA}

As Figuras 19 e 20 mostram o conjunto de perfis e mapas topográficos das três pequenas depressões estudadas.

Em termos de área, a Depressão Fechada é maior, com aproximadamente 7 mil $\mathrm{m}^{2}$. As Depressões Abertas 1 e 2 são menores, em torno de 4 e 3 mil $\mathrm{m}^{2}$ respectivamente.

A Depressão Aberta 1 é topograficamente mais baixa que a Depressão Aberta 2, que por sua vez é um pouco mais rebaixada que o nível do braço terminal da Vazante Castelo, onde se localiza. Suaves elevações no terreno, com aproximadamente 0,80 $\mathrm{m}$ de altura, separam as Depressões Abertas 1 e 2 (Figura 19 A).

As Depressões Abertas 1 e 2 (Figuras 19 B e C) são assimétricas. As bordas próximas à cordilheira são mais elevadas, com 1,10 e 1,20 m, e do lado oposto, próximo à vazante, com 0,75 e $0,80 \mathrm{~m}$ de altura. A DA1 tem forma alongada, com diâmetro de $95 \mathrm{~m}$ no eixo menor (Figura $20 \mathrm{E}$ ), e a DA2 tem forma circular e diâmetro de 75 m (Figura 20 F).

Ao contrário das anteriores, a Depressão Fechada tem um perfil simétrico (Figuras $19 \mathrm{D}$ ). A amplitude topográfica é de aproximadamente $0,80 \mathrm{~m}$ entre os pontos mais altos, próximos da cordilheira, e os mais baixos, no centro da depressão. A forma é circular, com fundo achatado, e diâmetro de 120 metros (Figura $20 \mathrm{G}$ ). 


\section{PERFIS TOPOGRÁFICOS}

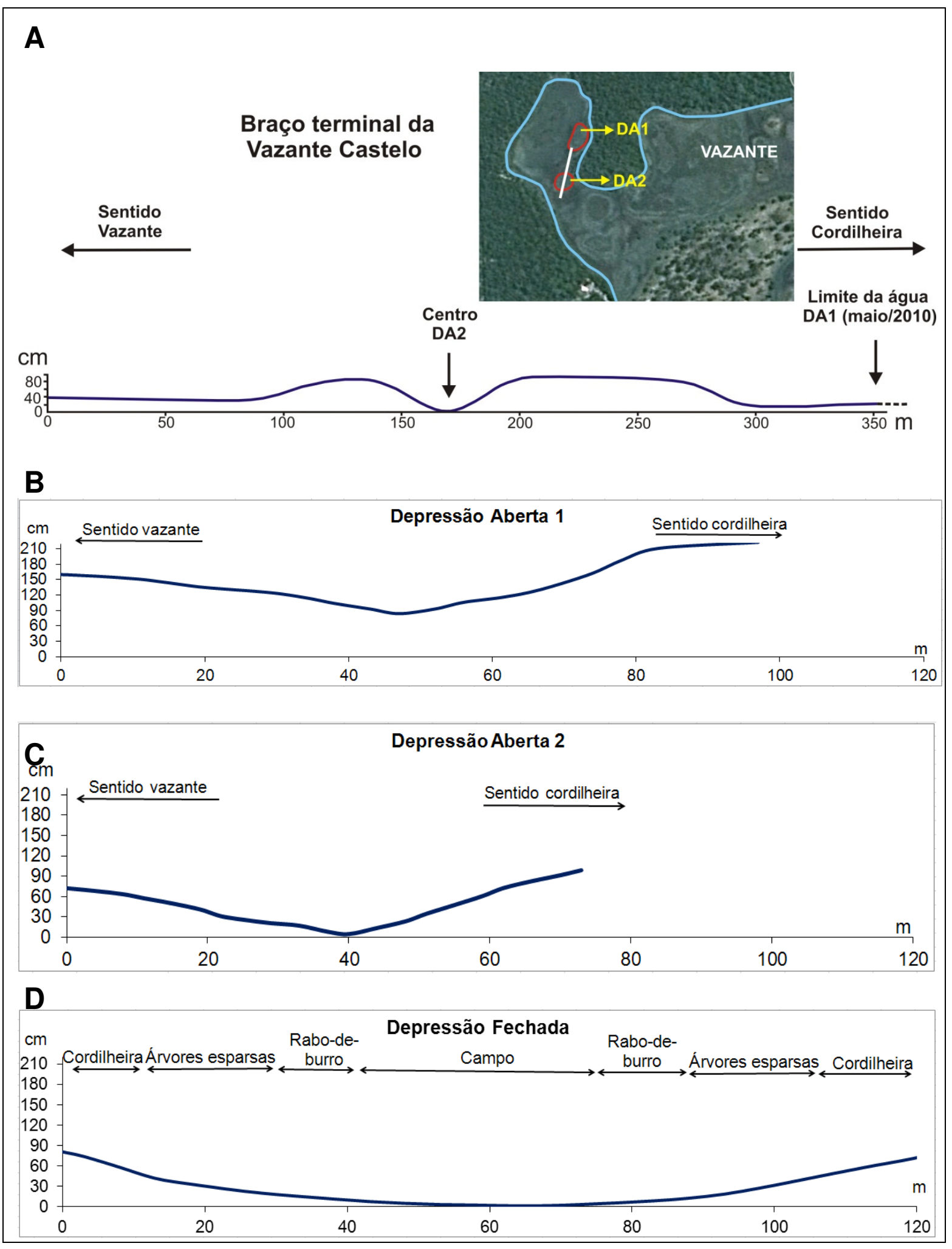

Figura 19 - Perfis topográficos: $(A)$ do braço terminal da vazante; (B) da Depressão Aberta 1; (C) da Depressão Aberta 2; (D) da Depressão Fechada. 


\section{MAPAS TOPOGRÁFICOS}

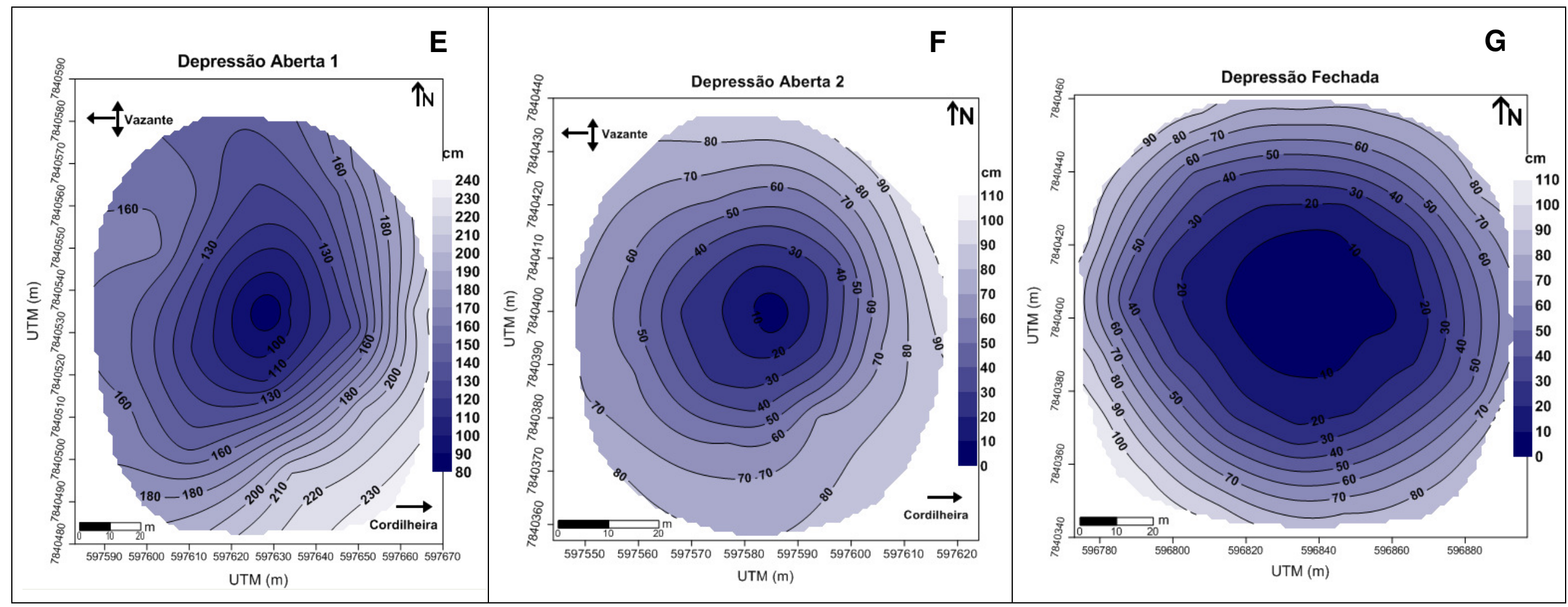

Figura 20 - Mapas topográficos das pequenas depressões: (E) Depressão Aberta 1, (F) Depressão Aberta 2 e (G) Depressão Fechada. 
Em síntese, as amplitudes topográficas não passam de 1,20 m, sobre 40 a 60 $\mathrm{m}$ de extensão, do centro até as bordas das depressões, mas são suficientes para definir essas unidades fisiográficas como "pequenas depressões". Os perfis das Depressões Abertas 1 e 2, com forma oval, são assimétricos, e o da Depressão Fechada, com forma arredondada, é simétrico.

\section{3 - VALIDAÇÃO DOS DADOS DE CONDUTIVIDADE ELÉTRICA APARENTE DOS SOLOS (CEa)}

A Figura 21 apresenta os gráficos de correlação entre valores da CEa obtidos pelo aparelho EM38 no campo, e pelo programa PCLoop 1.0, e se referem às Depressões Aberta 2 e Fechada.

Os dois gráficos mostram uma nítida correlação dos valores, mas as retas não passam pelo zero (0.0).

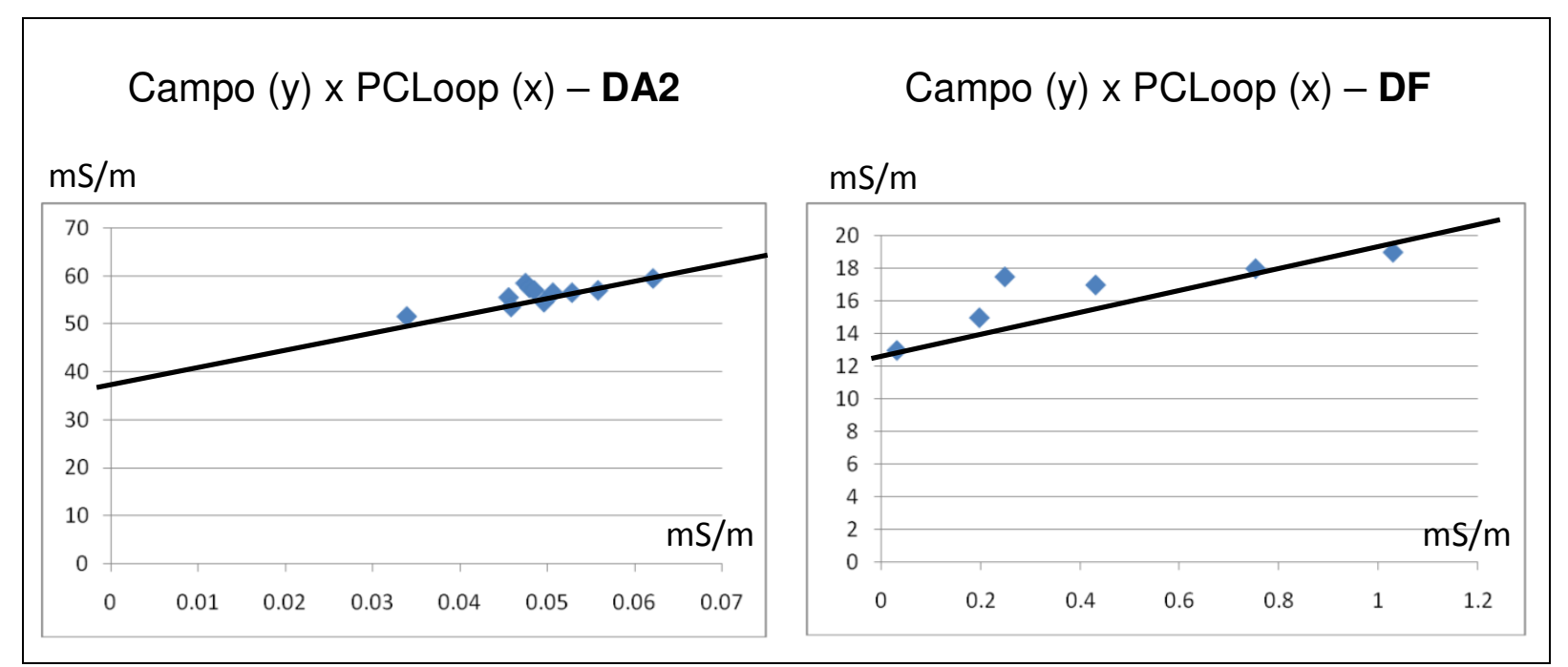

Figura 21 - Correlação dos valores de CEa (aparelho EM38 x PCLoop) na Depressão Aberta 2 (DA2) e na Depressão Fechada (DF). 


\section{4 - SEMIVARIOGRAMA E MAPA DA CONDUTIVIDADE ELÉTRICA APARENTE} (CEa)

Os semivariogramas experimentais e os modelos ajustados são apresentados nas Figuras 22 e 23. Os semivariogramas A, B, C e F foram melhor ajustados ao modelo linear, e os semivariogramas $D$ e $E$ a um modelo logarítmico.

$\mathrm{Na}$ Figura 22, referente à Depressão Aberta 2, os patamares atingem 4 $(\mathrm{mS} / \mathrm{m})^{2}$ no $A, 2,4$ no $B$ e 5 no $C$, com alcances de 25 e $30 \mathrm{~m}$. A anisotropia é relativamente fraca, com valor 2 e direções 37 e $39^{\circ}$ não muito marcadas. $O$ efeito pepita é nulo nos semivariogramas $A$ e $B$, mas não no $C$ (EM38-V), onde ele é de $0,5(\mathrm{mS} / \mathrm{m})^{2}$.

Na Figura 23, referente a Depressão Fechada, o patamar é de 0,8 $(\mathrm{mS} / \mathrm{m})^{2}$ no semivariograma $D$, de 1,2 no $E$, e de 3,5 no $F$, com alcances de 20 a $25 \mathrm{~m}$. A anisotropia é relativamente fraca, com valores $1,4,1,8$ e 2,0, e direções de $34^{\circ}$ no $D$, $20^{\circ}$ no $E$, e $22^{\circ}$ no $F$, não muito marcadas. $O$ efeito pepita é nulo nos semivariogramas $D$ e $F$, mas não no $E(E M 38-V)$, com aproximadamente 0,4 $(\mathrm{mS} / \mathrm{m})^{2}$.

Os mapas de condutividade elétrica aparente foram elaborados segundo os modelos linear e logarítmico dos semivariogramas correspondentes (Figuras 22 e 23). Para elaborar os mapas $\mathrm{C}$ e $\mathrm{E}$ não se levou em conta o efeito pepita muito discreto.

(a) $\mathrm{Na}$ Depressão Aberta 2 os valores da CEa variam de 4 a $15 \mathrm{mS} / \mathrm{m}$ com o EM31 em modalidades vertical e horizontal, e de 49,5 a $59,5 \mathrm{mS} / \mathrm{m}$ com o EM38 em modalidade vertical (Figura 22 A, B, C). Os valores intermediários e altos, representados pelas cores amarelo a vermelho escuro, estão circunscritos ao centro da depressão, e configuram uma faixa que a corta na direção NE-SW. Nas laterais opostas a essa faixa aparecem os valores mais baixos, representados pelas cores azul escuro a verde claro. Comparando-se os três mapas, nota-se que as distribuições desses valores são similares, porém, na Figura 22 B referente ao EM31-H, a faixa com valores altos e intermediários não é contínua, e os valores mais baixos ocupam maior área. 

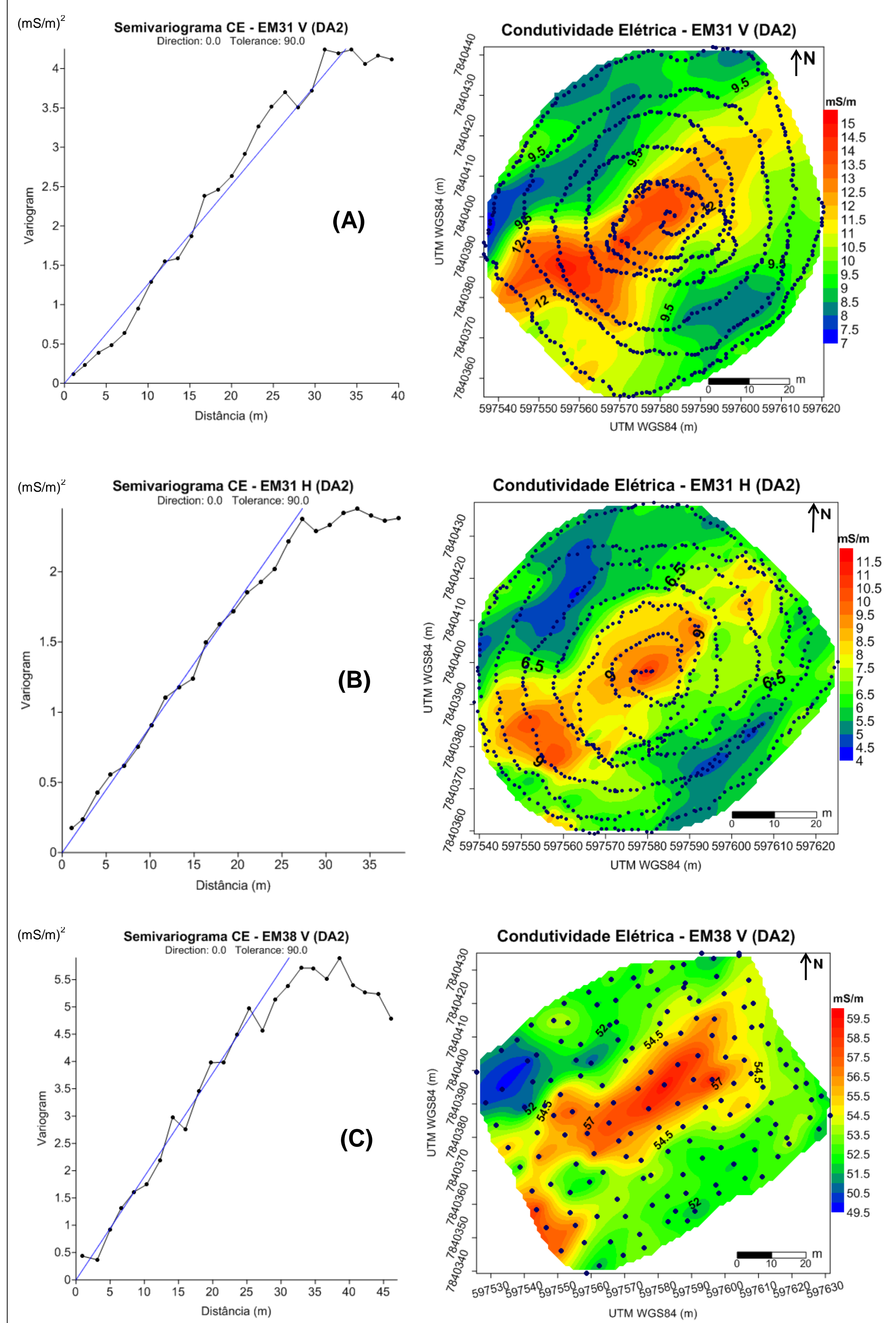

Figura 22 - Semivariogramas e respectivas interpolações espaciais dos valores da CEa na Depressão Aberta 2: (A) EM31 V; (B) EM31 H; (C) EM38 V. O pontilhado em azul indica os pontos de medidas. 


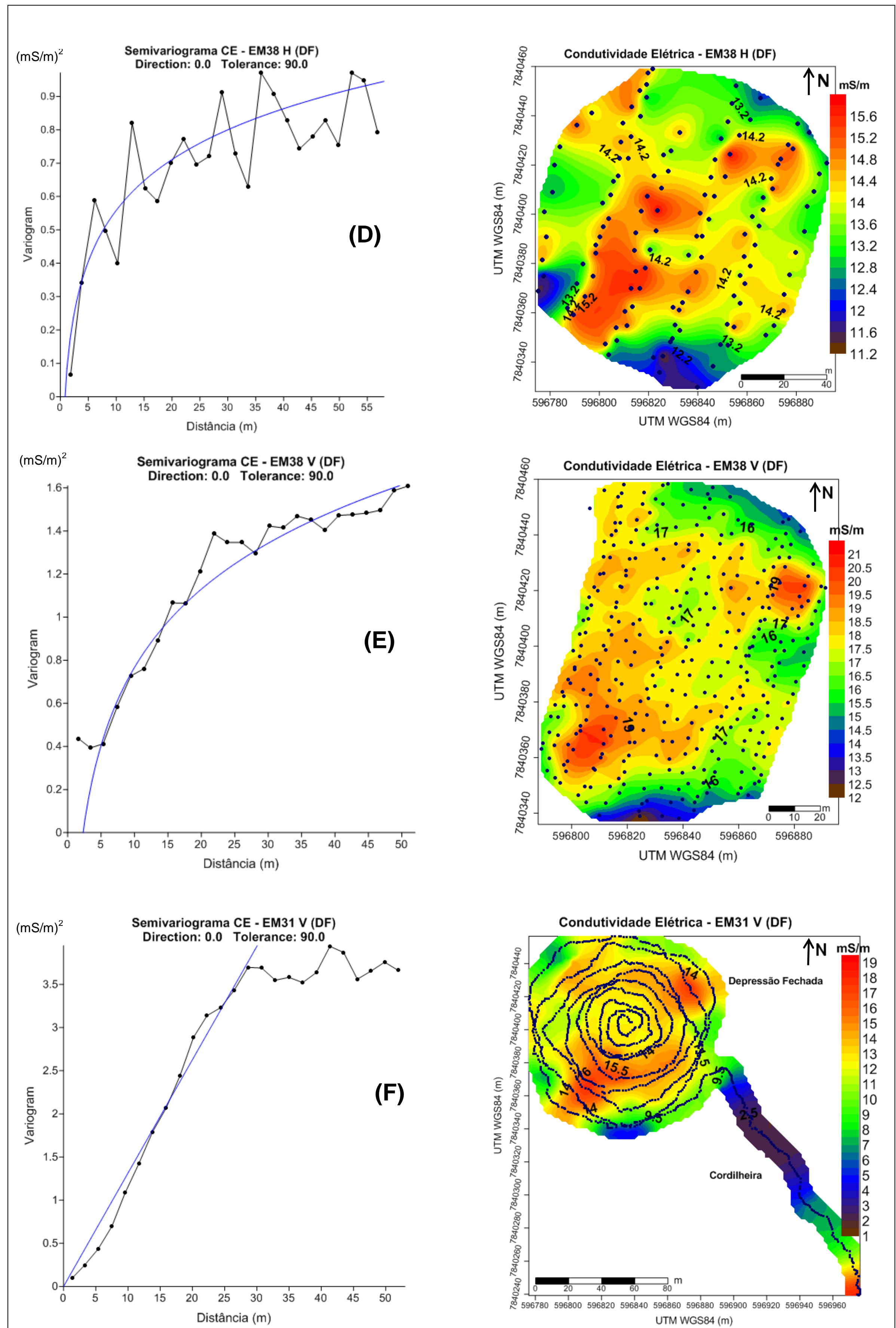

Figura 23 - Semivariogramas e respectivas interpolações espaciais dos valores de CEa na Depressão Fechada: (D) EM38 $\mathrm{H}$; (E) EM38 V; (F) EM31 V. O pontilhado em azul indica os pontos de medidas. 
(b) Na Depressão Fechada a gama total de valores de CEa varia de 11,2 a 21 $\mathrm{mS} / \mathrm{m}$ (Figura $23 \mathrm{D}$ e E), com o EM38 em modalidades horizontal e vertical respectivamente, e de 1 a $19 \mathrm{mS} / \mathrm{m}$ (Figura $23 \mathrm{~F}$ ) com o EM31 em modalidade vertical. Nos mapas $D$ e E, os menores valores, representados pelas cores marrom a verde claro, aparecem nas extremidades da depressão próximas da cordilheira, e os maiores valores, representados pelas cores laranja a vermelho escuro, distribuem-se em manchas individualizadas, sendo que no $\mathrm{D}$ as manchas são mais conectadas, e no $\mathrm{F}$ tendem a formar um anel descontínuo.

Em detalhe, na Figura 23 D, o EM38-H discrimina uma faixa que se estende da extremidade SW ao centro da depressão, com prolongamentos para NW, NE, SE em manchas menores individualizadas. Nos mapas E e F, os valores mais altos ocupam área menor, em manchas circunscritas às extremidades NE-SW. Em particular, com o EM31-V nota-se na Figura $23 \mathrm{~F}$, uma nítida tendência dos valores mais altos se distribuírem ao redor do centro da Depressão Fechada, formando uma faixa anelar descontínua, e também apresenta a distribuição espacial da CEa na cordilheira. Os menores valores aparecem nos limites da depressão com a cordilheira, e na própria cordilheira. Nota-se também que os valores aumentam gradativamente do final da cordilheira em direção à Baía situada a SE do mapa.

Finalmente, constata-se que o EM38 em modalidade horizontal (Figura 23 D) revela valores de CEa mais altos no centro da Depressão Fechada, que não aparecem discriminados nem com o EM38-V (Figura $23 \mathrm{E}$ ), nem com o EM31-V (Figura $23 \mathrm{~F}$ ).

Em síntese, retém-se os seguintes pontos dos estudos dos semivariogramas e dos mapas de CEa:

1 - os semivariogramas indicam que não é possível extrapolar os dados de CEa além de 20 ou $30 \mathrm{~m}$;

2 - o efeito pepita aparece somente com os dados do EM38 em modalidade vertical, nos mapeamentos das Depressões Aberta 2 (Figura 22 C), e Fechada (Figura 23 E). 3 - em todos os mapas, exceto no E (Figura 23), nota-se uma tendência dos maiores valores de CEa se circunscrevem ao centro das depressões; seja em forma de faixas cortando-as na direção NE-SW (Figuras 22 e 23 A, B, C e D), seja ao redor do centro em faixas anelares descontínuas (Figura 23 F). Apenas no mapa da Figura 
$23 \mathrm{E}$ é que os altos valores configuram duas manchas isoladas, uma a NE e outra a SW.

\section{5 - CARACTERÍSTICAS DO SISTEMA PEDOLÓGICO}

Apresenta-se neste tópico os estudos das características morfológicas dos solos por observações diretas, e a caracterização da fase sólida do solo por granulometria e resistividade dos horizontes, e difratometria da fração argila.

\section{A) Morfologia}

A.1 - Depressão Aberta 1: A Figura 24 apresenta a sequência de solos descrita na Depressão Aberta 1 (Figura 16-1).

Nesta sequência foi identificado um total de 6 horizontes, que se estendem, com variações de espessura, de uma extremidade a outra da depressão. Os horizontes (2) e (3) são mais espessos próximos à cordilheira, ao contrário do horizonte (4), cuja espessura é maior em direção à vazante, e do (5) mais espesso no centro da depressão.

Os horizontes (1), (2) e (3) têm textura arenosa, principalmente areia fina, são friáveis e com estrutura maciça. No horizonte (1) a cor é acinzentada (10YR 6/1), mais escura na superfície e mais clara na base, a 0,30 $\mathrm{m}$ de profundidade. A quantidade de raízes acompanha essa diferenciação de cor, mais numerosa no topo que na base do horizonte. A transição para o horizonte 2 é gradual, com limite ondulado. No horizonte (2) a cor é clara (10YR 8/2) com manchas amareloavermelhadas e escuras. O limite inferior com o horizonte subjacente é abrupto com forte contraste de cor. No horizonte (3) a cor é escura (10YR 3/2), com manchas esbranquiçadas, amarelo-avermelhadas e escuras, com nódulos pluricentimétricos de matéria orgânica ligeiramente endurecidos. A quantidade de manchas varia lateralmente. A transição do horizonte (3) para o (4) é abrupta. 


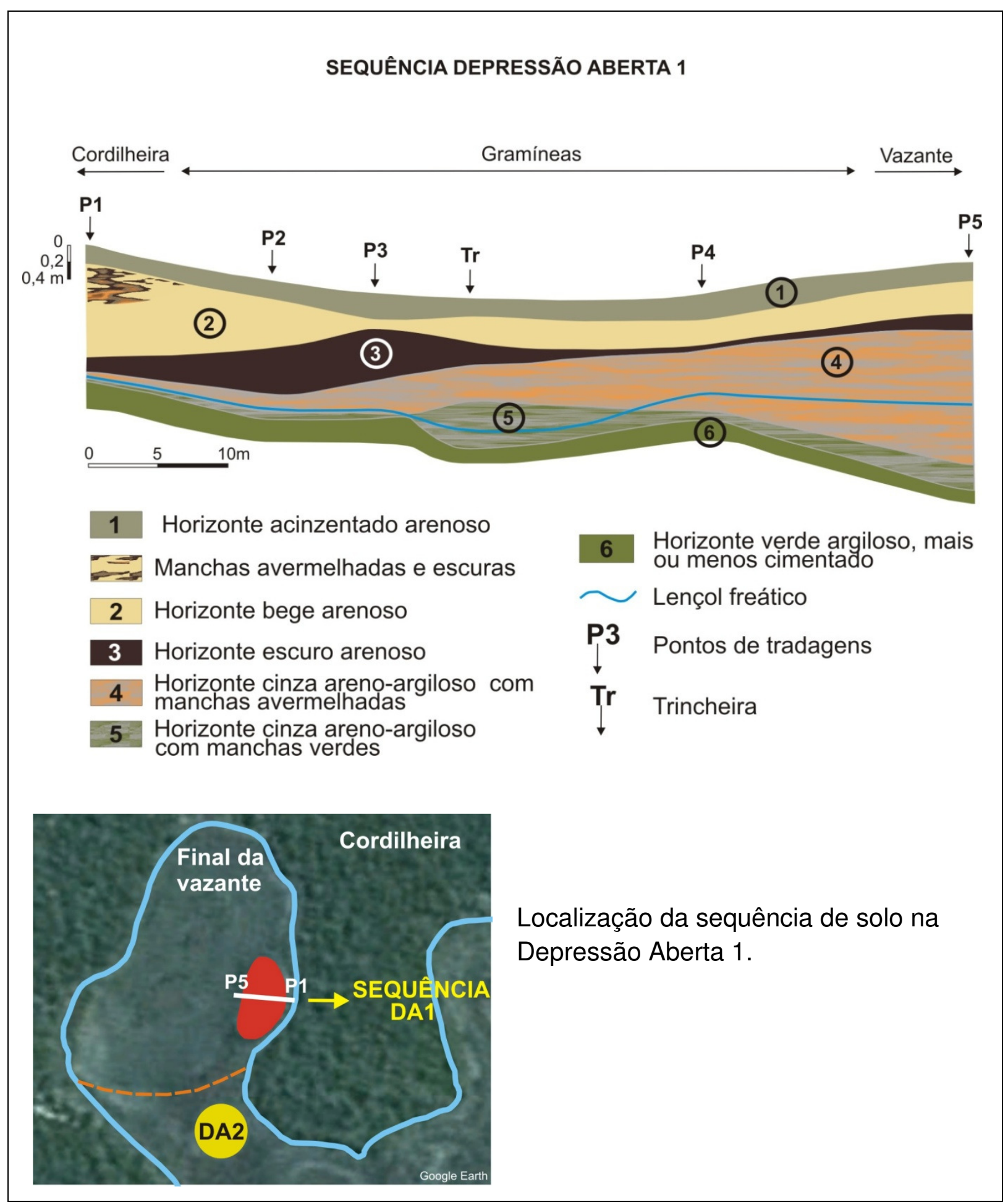

Figura 24 - Sequência de solos da Depressão Aberta 1 e sua localização na vazante.

O horizonte (4) apresenta mudanças graduais de textura e de cor do topo para a base. No topo a cor da matriz é cinza (10YR 5/2), com manchas avermelhadas (5YR 4/6), e linhas verticais escuras de matéria orgânica. A textura é arenosa, e a estrutura maciça. Na base do horizonte a cor da matriz muda, progressivamente, para um cinza mais claro (5Y 5/1), diminuem as manchas 
avermelhadas, e aparecem alguns volumes esverdeados mais coesos. A textura se torna ligeiramente argilosa. A transição para o horizonte (5) é gradual com limite irregular.

O horizonte (5) é areno-argiloso, com a mesma cor cinza claro (5Y 5/1) do horizonte 4 , porém com maior quantidade de volumes esverdeados e manchas avermelhadas e cinzas bem difusas. A transição para o próximo horizonte é gradual.

$\mathrm{Na}$ base do perfil, o horizonte (6) possui textura argilosa, estrutura maciça, a cor cinza (5Y 5/1), com grande quantidade de volumes verdes mais ou menos secos, e cimentados, cuja cor varia de Gley $14 / 5$ G a 3/5 G. Este horizonte quando seco apresenta consistência muito dura. A forma é ondulada com subidas nos pontos $\mathrm{P} 3$ e $\mathrm{P} 4$, e descidas nos pontos $\mathrm{Tr}$ e P5, e espessura irregular.

Nessa sequência, entre os pontos $\mathrm{P} 1$ e P3, o lençol freático se situa entre os horizontes (4) e (5), e desce até 2,40 m no horizonte (5), entre os pontos P3 e P4, acompanhando a subida e descida deste horizonte. Do ponto $\mathrm{P} 4$ em direção à vazante o lençol se instala no horizonte (4).

A.2 - Depressão Aberta 2: A Figura 25 apresenta a sequência de solos descrita na Depressão Aberta 2, de T1 a T2, e seu prolongamento lateral, de T2 a T5 (Figura 16-2).

Nesta sequência também foram identificados 6 horizontes, que se estendem do centro até a borda da depressão, com excessão do horizonte (1b) marrom-escuro arenoso, que aparece somente entre os horizontes (2) e (4a), com espessura máxima de 0,15 m. Observam-se variações de espessuras ligadas a suaves ondulações dos horizontes, especialmente do (7), que acompanha as subidas e descidas do horizonte (6) profundo.

Os horizontes (1a) e (2) são quase plano-paralelos, e concordantes com a topografia atual.

Os horizontes (1a), (2) e (1b) são arenosos e se diferenciam apenas pela cor. A cor é marrom escuro (10YR 2/2), com raízes, no (1a) e (1b), e no horizonte (2) mais clara (10YR 6/3), com manchas difusas escuras e amarelo-avermelhadas . A transição é abrupta do (1a) para o horizonte (2), e abrupta deste para o (4a), dada pela mudança de cor e textura. 


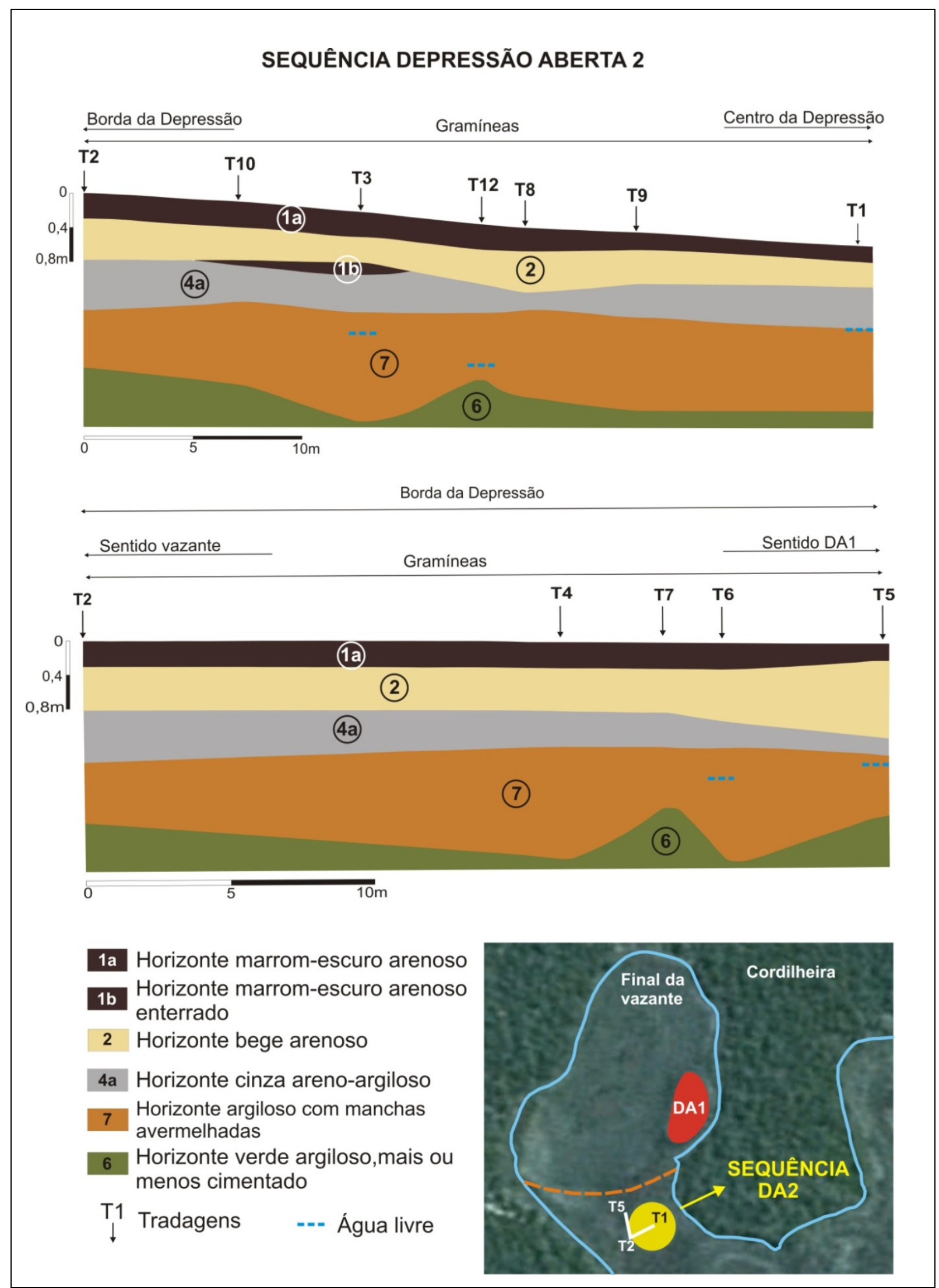

Figura 25 - Sequência de solos na Depressão Aberta 2. 
O horizonte (4a) é areno-argiloso, cor cinza (5Y 5/1) e manchas difusas escuras e amarelo-avermelhadas. A transição é gradual para o horizonte (7), que apresenta textura nítidamente argilosa, com grande quantidade de volumes secos avermelhados, centimétricos. A cor do (7) é variegada, com abundantes volumes avermelhados, vermelho-amarelados, acinzentados e esbranquiçados, que dificultam determinar a cor exata da matriz. Esses volumes são mais abundantes no topo, e diminuem na base do horizonte, onde prevalecem os de cor esverdeada. Lateralmente, em direção ao centro da depressão, a textura passa a ser menos argilosa, ligeiramente arenosa. A transição do horizonte (7) para (6) é gradual.

O horizonte (6) também é argiloso, porém menos que o horizonte (7), a cor da matriz é cinza (Gley 5/10Y), com bastante volumes esverdeados, mais ou menos cimentados, de cor Gley 4/10 GY a Gley 3/5 GY. A forma é irregular, com subidas nos pontos T7, T5 e T12, e descidas nos pontos T6, T3.

A sequência lateral da DA2 tem apenas 5 horizontes, pois não aparece 0 horizonte superficial (1b) enterrado. Os horizontes (1a), (2) e (4a) são quase planoparalelos, e o horizonte (6) profundo faz apenas uma elevação entre os pontos T6 e T7. O horizonte (7) possui as mesmas características morfológicas do horizonte (7) descrito na sequência anterior, com textura argilosa e volumes avermelhados secos.

Nessas duas sequências encontra-se água livre pontualmente, no T1 $(1,20$ $\mathrm{m})$, no T12 (1,60 m), no T3 (1,50 m), no T5 (1,50 m) e no T6 (1,60 m).

\section{A.3 - Sequência entre as Depressões Abertas 1 e 2: A Figura 26} apresenta a sequência de solo feita entre a DA1 e DA2. Nela foram identificados 5 horizontes. No topo da elevação aparece um horizonte superficial amarelo arenoso (1c), e o marrom-escuro arenoso (1a) apenas nas extremidades laterais. Nessa sequência não aparece o horizonte argiloso com manchas avermelhadas (7).

Os horizontes (1a), (1c) e (2) são arenosos. A cor no horizonte (1a) é marrom escuro (10YR 2/2), e no (1c) amarelada (10YR 4,5/6). Neste horizonte aparecem concreções ferruginosas a $0,35 \mathrm{~m}$ de profundidade, e no limite com o horizonte (2).

O horizonte (2) é arenoso, cor bege claro (10YR 6/3), com manchas amareloavermelhadas. Ele é mais espesso do lado da DA1, e se estreita em direção à DA2. Ele aflora em superfície nas extremidades dos horizontes (1a) e (1c), em ambos os lados da sequência. A transição é plana e abrupta para o horizonte (4a). A textura do (4a) é areno-argilosa, e a cor é cinza (5Y 5/1), com manchas escuras nas 
extremidades próximas às depressões, que não aparecem nem na DA1, nem na DA2. Ao contrário do horizonte (2), o (4a) é mais espesso próximo à DA2, e quase desaparece em direção à DA1.

A transição do (4a) para o horizonte (6) é gradual, com forma ondulada. $O$ horizonte (6) é argiloso, com cor cinza (Gley 5/10Y), e grande quantidade de volumes esverdeados cimentados. Ele apresenta uma elevação no ponto S6, e uma descida no ponto S7

O lençol freático encontra-se praticamente na base do horizonte (2), mais alto na proximidade da DA1, e com uma ligeira caída a partir do ponto $S 3$, em direção à DA2.

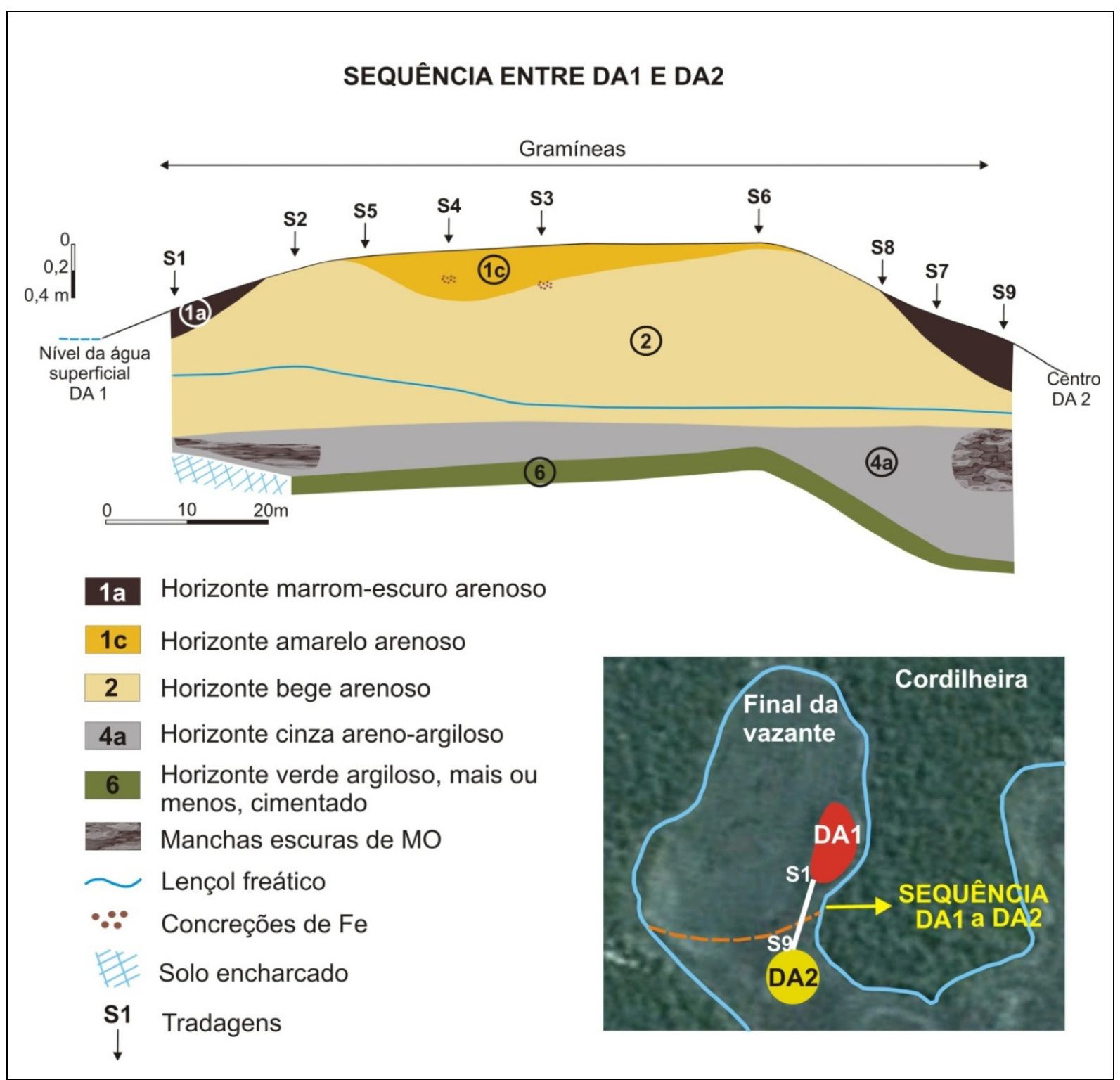

Figura 26 - Sequência entre as Depressões Abertas 1 e 2. 
A.4 - Depressão Fechada: A Figura 27 apresenta a sequência de solo descrita na Depressão Fechada. Nesta sequência foram identificados 5 horizontes, com o horizonte (1) concordante com a topografia, e o horizonte (1c) circunscrito somente ao centro da depressão. A Figura 28 apresenta os limites deste horizonte, cujo diâmetro aproximado é de 8 metros.

Os horizontes não apresentam grandes variações de espessura, exceto 0 horizonte (2), mais espesso próximo à cordilheira, e o (4a) muito delgado.

Os horizontes (1), (1c), (2) e (4a) são arenosos, friáveis, com estrutura maciça, e se diferem apenas pela cor. No horizonte (1) a cor é mais escura (7,5YR 4,5/3), com presença de raízes, com transição gradual para o horizonte (2), mais úmido, de cor mais clara (7,5YR 7/3), e manchas difusas amarelo-avermelhadas (7,5YR 5/6). A espessura do horizonte (2) varia de $2,50 \mathrm{~m}$, próximo à cordilheira, a $1,50 \mathrm{~m}$ no centro da depressão. No ponto G5 ele apresenta nódulos endurecidos de ferro, e nos pontos G3 e G4, volumes de matéria orgânica pretos (10YR 2/1), brilhantes e consistência oleosa.

No topo do horizonte (2) aparece no centro da depressão, ponto G6, o horizonte (1c), de cor amarelada (10YR 4,5/6), espessura de $30 \mathrm{~cm}$, e nódulos ferruginosos na base. A transição do horizonte (1) para o (1a) é gradual, e para o horizonte (2) é abrupta. A transição também é abrupta do (2) para o (4a).

O horizonte (4a) é arenoso, de cor cinza (Gley 5/10Y), e muito úmido. Apresenta forma ondulada, que acompanha as subidas e descidas do horizonte (6) subjacente.

O horizonte (6) é argiloso, matriz cinza (Gley $5 / 10 \mathrm{Y}$ ), com grande quantidade de volumes verdes (Gley 5/5GY). A sua forma é irregular com subidas nos pontos G4 e G7, e descidas nos pontos G6 e G3.

O lençol freático se localiza próximo à base do horizonte (2), e permanece nessa posição de uma extremidade a outra da depressão. 


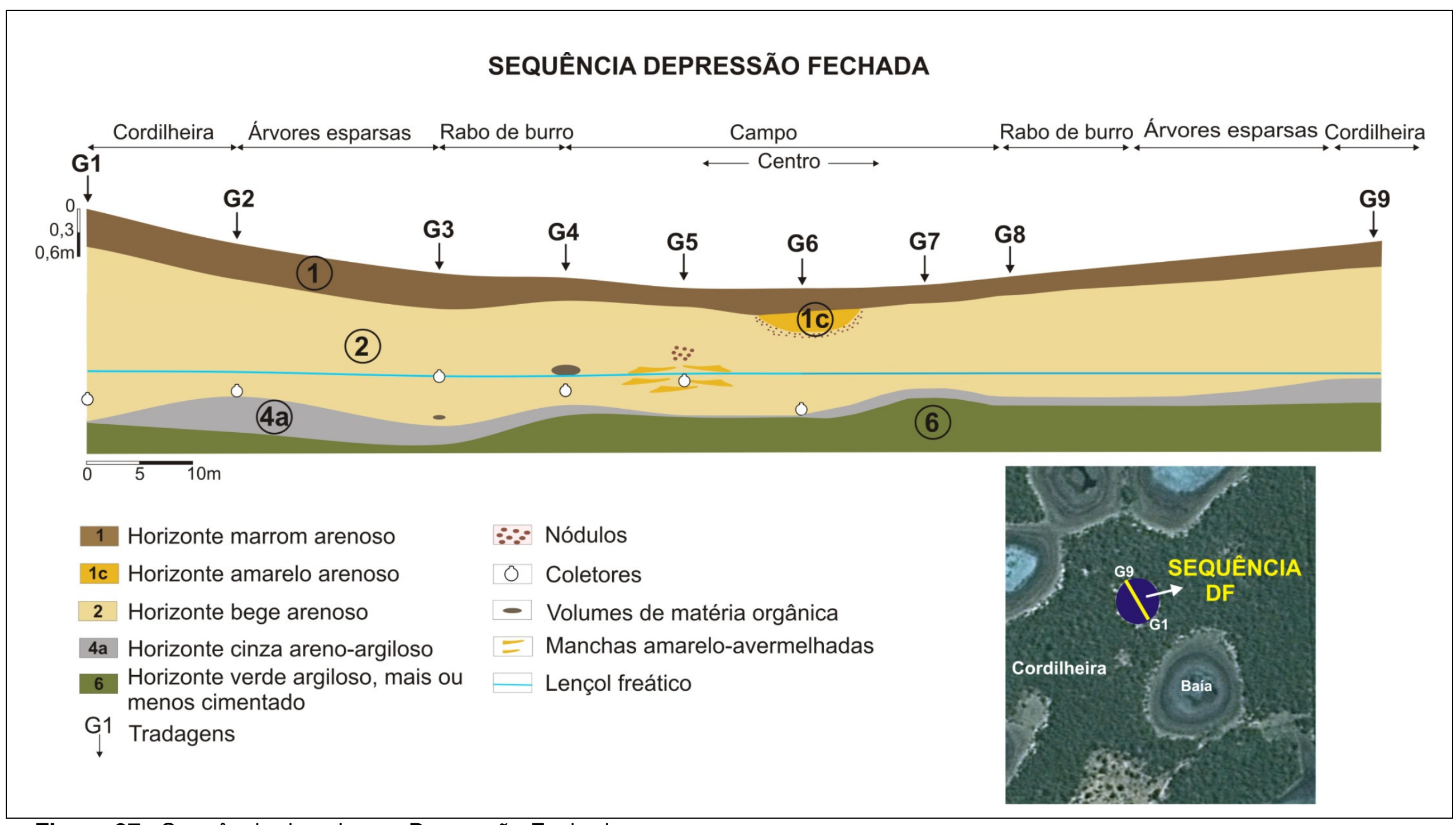

Figura 27 -Sequência de solos na Depressão Fechada. 


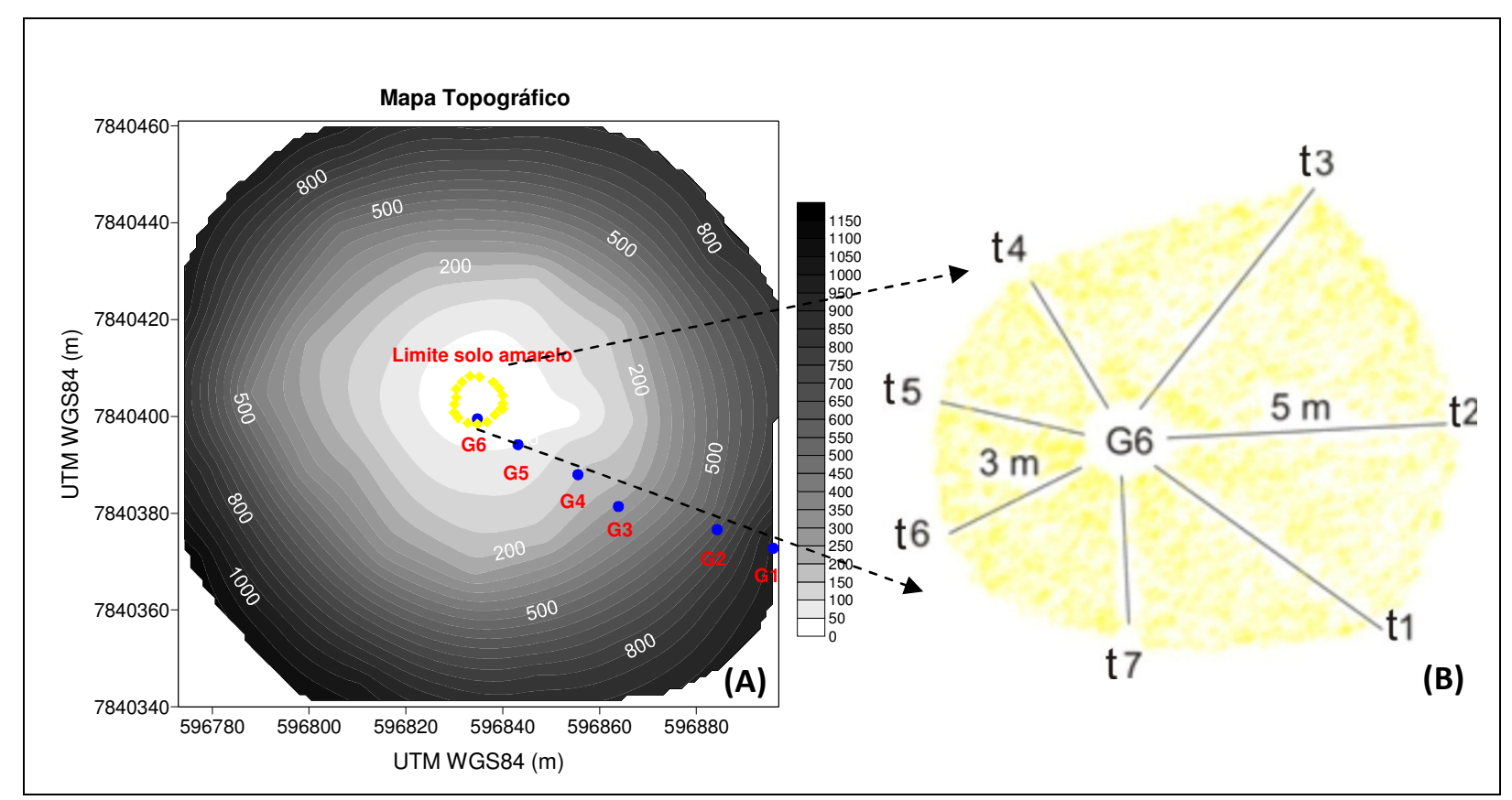

Figura 28 - (A) Localização e (B) delimitação do horizonte amarelo arenoso no centro da Depressão Fechada (t1 = pontos de tradagens).

\section{B) Resistividade}

Os valores de resistividade são apresentados na Tabela 3, e se referem aos horizontes (1 e 2), (1c) e (6) da Depressão Fechada, e aos horizontes (1a), (2), (6) e (7) da Depressão Aberta 2.

Na Depressão Fechada, o horizonte menos resistivo é o (6) verde argiloso com 73 ohm.m, e os mais resistivos os horizontes arenosos de superfície e subsuperfície (1 e 2), com $11.10^{3}$ ohm.m, seguido do (1c) amarelo arenoso, com $3.10^{3} \mathrm{ohm} . \mathrm{m}$.

Na Depressão Aberta 2 o horizonte (7) argiloso é o menos resistivo, com 43 ohm.m, seguido pelos horizontes (6) verde argiloso com 70 ohm.m, e (4a) cinza areno-argiloso com 84 ohm.m. O horizonte arenoso superficial (1a) é o mais resistivo, com $2.10^{3}$ ohm.m. 
Tabela 3 - Valores de resistividade dos horizontes identificados na Depressão Fechada (DF) e Depressão Aberta 2 (DA2).

\begin{tabular}{cc|cc}
\hline \multicolumn{4}{c}{ RESISTIVIDADE } \\
\hline DEPRESSÃO FECHADA & \multicolumn{2}{c}{ DEPRESSÃO ABERTA 2 } \\
\hline Horizonte & $\begin{array}{c}\text { Resist. } \\
\text { (ohm.m) }\end{array}$ & Horizonte & $\begin{array}{c}\text { Resist. } \\
\text { (ohm.m) }\end{array}$ \\
\hline (1) e (2) - Arenosos & $11.10^{3}$ & $\begin{array}{c}\text { (1a) - Marrom-escuro } \\
\text { arenoso }\end{array}$ & $2.10^{3}$ \\
(1c) - Amarelo arenoso & $3.10^{3}$ & $\begin{array}{c}\text { (4a) - Cinza areno- } \\
\text { argiloso }\end{array}$ & 84 \\
(6) - Verde argiloso, mais & 73 & $\begin{array}{c}\text { (6) - Verde argiloso, mais } \\
\text { ou menos cimentado } \\
\text { ou menos cimentado }\end{array}$ & 70 \\
& & $\begin{array}{c}\text { (7) - Argiloso com } \\
\text { manchas avermelhadas }\end{array}$ & 43 \\
\hline
\end{tabular}

\section{C) Constituintes sólidos}

As Tabelas 4, 5 e 6 apresentam os resultados das análises granulométricas das Depressões Abertas 1 e 2, e da Fechada. As Figuras 29 e 30 mostram as localizações das amostragens de solos nas Depressões Abertas 1 e 2, e a Figura 31 apresenta as classes texturais de cada um dos horizontes, de acordo com os valores percentuais das frações areia, silte e argila.

Em todos os horizontes da Depressão Aberta 1 há predomínio da fração areia, cujo total varia de 90 a $68 \%$. Desse total, a maior porcentagem é de areia fina nos horizontes superficiais (1) e (2), e de areia muito fina nos horizontes intermediários (3) e (4), e profundos (5) e (6). As porcentagens de silte variam de 7 a $14 \%$, sendo que os horizontes superficial (1), e profundos (5) e (6) apresentam as maiores porcentagens, 14,1 a $13,5 \%$ respectivamente. No geral, as porcentagens de argila são baixas, e variam de 1,8 a $10 \%$, exceto no horizonte (6) profundo, onde atinge $18,2 \%$. O horizonte (2) bege arenoso com um total de $90 \%$ de areia é o que apresenta menor porcentagem de argila, de 1,8\%. A porcentagem de matéria orgânica mais alta é de $3,46 \%$ no horizonte (1), e a mais baixa, de $0,17 \%$ no horizonte (2). Os horizontes (1) e (3) da Depressão Aberta 1 se enquadram na classe textural areia franca, o horizonte (2) na arenosa, e os horizontes (4), (5) e (6) na franco-arenosa (Figura 31). 
Tabela 4 - Dados da análise granulométrica da Depressão Aberta 1.

FAIXA GRANULOMÉTRICA (\%)

\begin{tabular}{|c|c|c|c|c|c|c|c|c|c|}
\hline \multirow[b]{2}{*}{ Nome dos Horizontes } & \multicolumn{5}{|c|}{ AREIA } & \multirow[b]{2}{*}{ Total } & \multicolumn{3}{|c|}{ PELÍTICOS } \\
\hline & $\begin{array}{l}\text { Muito } \\
\text { grossa }\end{array}$ & Grossa & Média & Fina & $\begin{array}{l}\text { Muito } \\
\text { fina }\end{array}$ & & Argila & Silte & MO \\
\hline $\begin{array}{l}\text { Horizonte acinzentado arenoso } \\
\text { (1) }\end{array}$ & 0,01 & 0,41 & 6,97 & 39,07 & 32,05 & 78,51 & 7,46 & 14,03 & 3,46 \\
\hline Horizonte bege arenoso (2) & 0,00 & 0,36 & 6,89 & 43,51 & 40,19 & 90,95 & 1,87 & 7,18 & 0,17 \\
\hline Horizonte escuro arenoso (3) & 0,00 & 0,40 & 7,08 & 33,41 & 42,69 & 83,58 & 8,42 & 7,99 & 1,47 \\
\hline $\begin{array}{l}\text { Horizonte cinza areno-argiloso } \\
\text { com manchas avermelhadas (4) }\end{array}$ & 0,00 & 0,34 & 6,48 & 34,12 & 38,39 & 79,33 & 10,24 & 10,44 & 1,55 \\
\hline $\begin{array}{l}\text { Horizonte cinza areno-argiloso } \\
\text { com manchas verdes (5) }\end{array}$ & 0,57 & 0,59 & 5,34 & 27,66 & 40,02 & 74,18 & 10,46 & 14,13 & - \\
\hline $\begin{array}{l}\text { Horizonte verde argiloso, mais ou } \\
\text { menos cimentado (6) }\end{array}$ & 0,03 & 0,36 & 6,10 & 18,97 & 42,74 & 68,2 & 18,23 & 13,50 & - \\
\hline
\end{tabular}

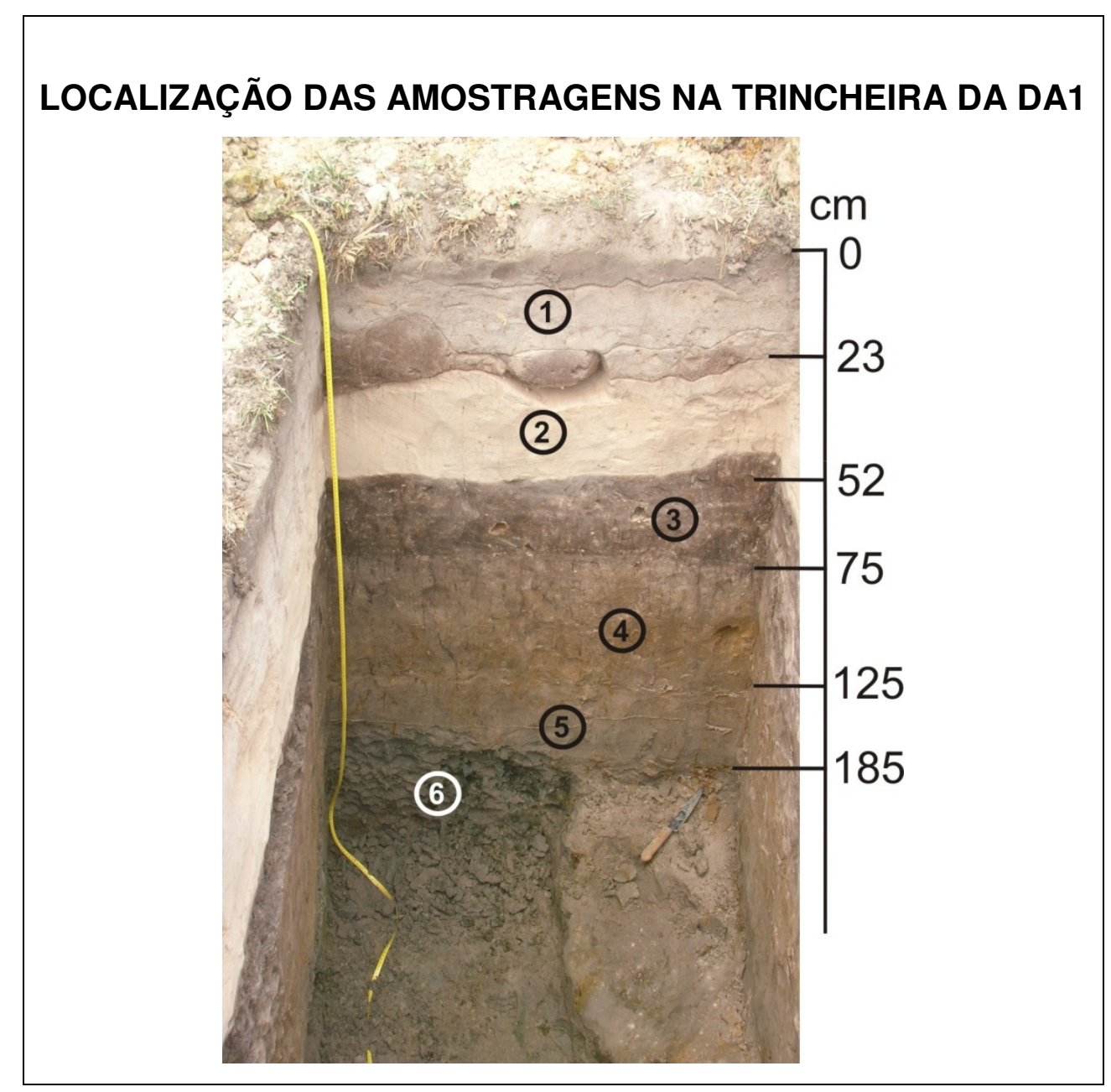

Figura 29 - Localizações das amostras de solos coletadas para granulometria na trincheira da Depressão Aberta 1, localizada no centro da depressão. 
$\mathrm{Na}$ Depressão Aberta 2 a fração areia também predomina, com os totais apresentando grandes variações, de 43 a 93\%. Desses totais, as frações areia fina e muito fina são as de maior peso no conjunto dos horizontes. Nota-se que em todos os horizontes localizados no centro da depressão ( $\mathrm{T} 1$ ) predomina a fração areia muito fina.

A fração silte varia de 4,5 a 16,5\%, sendo que na maioria dos horizontes ela é inferior a $10 \%$, e apenas no horizonte (7), argiloso, atinge $16,5 \%$ no ponto $\mathrm{T} 10$, que se localiza próximo à borda da depressão. O horizonte (7) apresenta os percentuais mais altos de argila de todas as sequências estudadas, principalmente no ponto T10, que varia de $31 \%$ no topo, a $40,1 \%$ na base do horizonte. Lateralmente, a porcentagem de argila diminui para $10 \%$ no centro da depressão. Os percentuais mais baixos de argila variam de 4,3\% no horizonte superfical arenoso (1), e de 1,7\% no (2), ambos localizados no ponto T10. A quantidade de MO varia de 0,3 a 1,9\% nos horizontes superficiais (1a) e subsuperficiais (2), (1b) e (4a). O menor valor, $0,27 \%$ está localizado no horizonte arenoso (2), e o maior, de 1,87\%, no (4a), ambos localizados no ponto T10.

Os horizontes (1a) e (2) da Depressão Aberta 2 apresentam 81 a $93 \%$ de areia total, e se enquadram nas classes texturais areia e areia franca. Nos horizontes (4a) e (6) a porcentagem de areia diminui em relação aos horizontes superiores, e variam de 74 a $86,5 \%$. Ao contrário, a porcentagem de argila é mais alta. Esses percentuais enquadram estes horizontes como franco-arenosos. De toda a sequência, o horizonte (7) apresenta as porcentagens mais altas de argila, 40\%, e de silte, 16,5\%, que o enquadra no limite das classes argilosa e franco-argilosa. No entanto, lateralmente, em direção ao centro da depressão, com porcentagens de argila e silte menores, a textura deste horizonte passa a ser franco-arenosa (Figura 31). 
Tabela 5 - Dados da análise granulométrica da Depressão Aberta 2.

FAIXA GRANULOMÉTRICA (\%)

\begin{tabular}{|c|c|c|c|c|c|c|c|c|c|c|}
\hline \multirow[b]{2}{*}{ Nome dos Horizontes } & \multirow{2}{*}{$\begin{array}{c}\text { Ponto de } \\
\text { tradagem e } \\
\text { profundidade }\end{array}$} & \multicolumn{6}{|c|}{ AREIA } & \multicolumn{3}{|c|}{ PELÍTICOS } \\
\hline & & \begin{tabular}{|l|} 
Muito \\
grossa \\
\end{tabular} & Grossa & Média & Fina & $\begin{array}{c}\text { Muito } \\
\text { fina }\end{array}$ & Total & Argila & Silte & MO \\
\hline \multirow{3}{*}{$\begin{array}{l}\text { Horizonte marrom- } \\
\text { escuro arenoso } \\
\text { (1a) }\end{array}$} & T1 0-15 & 0,01 & 0,53 & 8,33 & 34,16 & 41,21 & 84,24 & 7,52 & 8,24 & 1,15 \\
\hline & T12 0-25 & 0,00 & 0,37 & 8,36 & 44,60 & 29,34 & 82,68 & 7,45 & 9,87 & 1,52 \\
\hline & T10 0-30 & 0,00 & 0,40 & 8,49 & 41,71 & 39,66 & 90,26 & 4,35 & 5,39 & 1,42 \\
\hline \multirow{3}{*}{$\begin{array}{l}\text { Horizonte bege } \\
\text { arenoso } \\
\text { (2) }\end{array}$} & $15-45$ & 0,00 & 0,47 & 8,79 & 28,85 & 43,02 & 81,13 & 8,86 & 10,02 & 1,02 \\
\hline & T12 35-80 & 0,01 & 0,45 & 10,43 & 43,35 & 34,44 & 88,69 & 6,78 & 4,53 & 0,82 \\
\hline & T10 & 0,02 & 0,53 & 10,71 & 45,32 & 37,06 & 93,63 & 1,66 & 4,71 & 0,27 \\
\hline \multirow{2}{*}{$\begin{array}{l}\text { Horizonte marrom- } \\
\text { escuro arenoso } \\
\text { enterrado (1b) }\end{array}$} & T3 60-70 & 0,00 & 0,51 & 11,95 & 35,19 & 38,07 & 85,73 & 8,43 & 5,84 & 0,97 \\
\hline & T10 70-75 & 0,02 & 0,38 & 8,95 & 41,03 & 33,45 & 83,83 & 10,91 & 5,26 & 1,43 \\
\hline \multirow{4}{*}{$\begin{array}{l}\text { Horizonte cinza } \\
\text { areno-argiloso } \\
\text { (4a) }\end{array}$} & & 0,01 & 0,26 & 6,86 & 33,11 & 36,81 & 77,05 & 15,99 & 6,97 & 1,55 \\
\hline & T12 80-105 & 0,02 & 0,54 & 9,58 & 36,66 & 39,67 & 86,48 & 7,55 & 5,97 & 0,73 \\
\hline & T3 70-80 & 0,00 & 0,72 & 11,61 & 38,37 & 33,38 & 84,07 & 10,54 & 5,38 & 1,00 \\
\hline & T10 75-100 & 0,03 & 0,54 & 11,45 & 37,73 & 27,45 & 77,19 & 17,99 & 4,82 & 1,87 \\
\hline \multirow{4}{*}{$\begin{array}{l}\text { Horizonte argiloso } \\
\text { com manchas } \\
\text { avermelhadas } \\
\text { (7) }\end{array}$} & $120-1$ & 0 , & 0,7 & 5,34 & 24,61 & 40,85 & 71,71 & 18,78 & 9,49 & - \\
\hline & T12 120-160 & 0,00 & 0,26 & 8,59 & 37,71 & 36,87 & 83,42 & 8,51 & 8,09 & - \\
\hline & T10 120-145 & 0,00 & 0,23 & 4,12 & 28,96 & 25,69 & 59,00 & 31,21 & 9,79 & - \\
\hline & T10 175-200 & 0,03 & 0,39 & 7,28 & 14,71 & 21,02 & 43,44 & 40,06 & 16,51 & - \\
\hline \multirow{4}{*}{$\begin{array}{l}\text { Horizonte verde } \\
\text { argiloso, mais ou } \\
\text { menos cimentado (6) }\end{array}$} & T1 200-220 & 0,02 & 0,43 & 11,04 & 31,69 & 37,83 & 81,01 & 10,39 & 8,59 & - \\
\hline & T8 230-250 & 0,70 & 1,35 & 13,65 & 36,64 & 22,09 & 74,43 & 15,68 & 9,79 & - \\
\hline & T1 & 0,15 & 1,5 & 27,31 & 35,90 & 18,69 & 83,61 & 9,52 & 6,88 & - \\
\hline & T10 240-295 & 0,15 & 0,64 & 16,17 & 41,31 & 23,41 & 81,68 & 12,25 & 5,96 & - \\
\hline
\end{tabular}

\section{LOCALIZAÇÃO DOS PONTOS AMOSTRADOS NA DEPRESSÃO ABERTA 2}

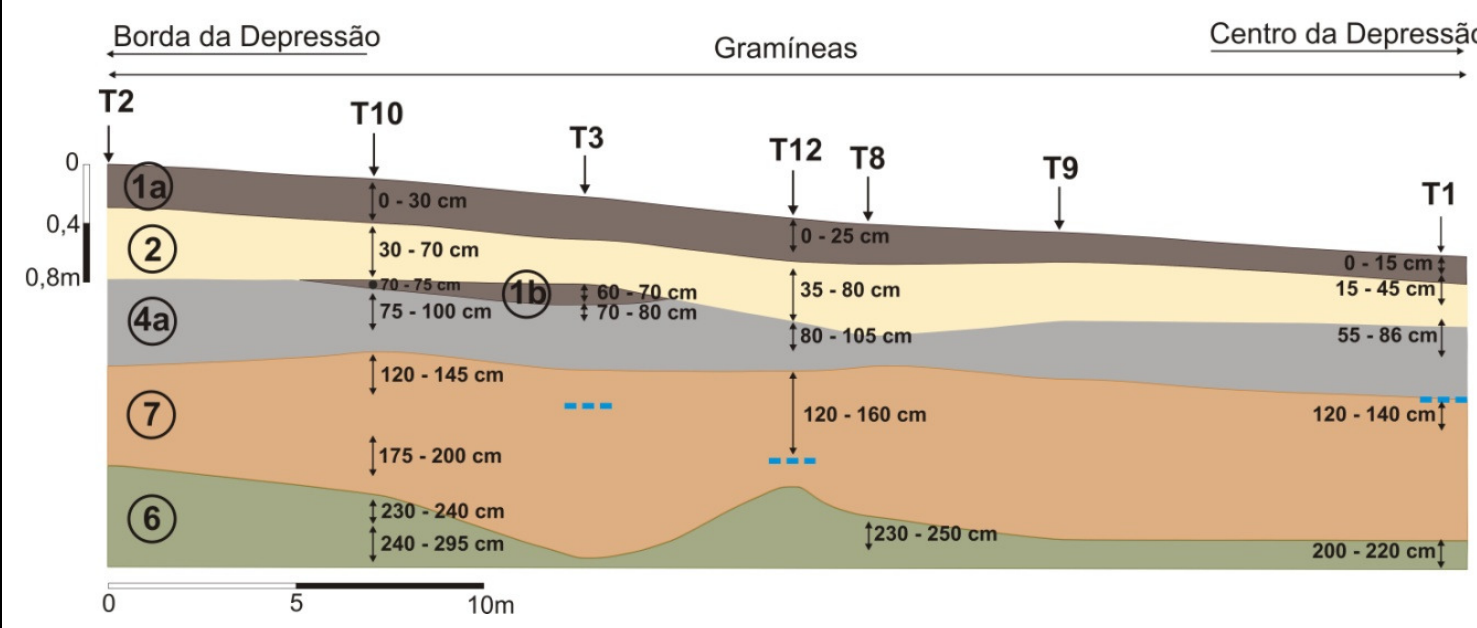

Figura 30 - Localização das coletas de amostras de solos para análise granulométrica na Depressão Aberta 2. 
$\mathrm{Na}$ Depressão Fechada a fração areia varia de 59 a 94\%, e desse total predomina a fração muito fina, de 36 a 47,5\%. Nos horizontes superficiais e subsuperficiais as porcentagens de argila variam de 1,6 a $0,45 \%$, e de 9 a $5 \%$ de silte, ou seja, são baixas. No horizonte (6), mais profundo, a argila atinge $27 \%$, o silte $13,6 \%$, e o total de areia $59 \%$.

Tabela 6 - Resultados da análise granulométrica dos horizontes da Depressão Fechada.

FAIXA GRANULOMÉTRICA (\%)

\begin{tabular}{|c|c|c|c|c|c|c|c|c|c|}
\hline \multirow[b]{2}{*}{ Nome dos Horizontes } & \multirow{2}{*}{$\begin{array}{l}\text { Código da } \\
\text { amostra }\end{array}$} & \multicolumn{6}{|c|}{ AREIA } & \multicolumn{2}{|c|}{ PELÍTICOS } \\
\hline & & $\begin{array}{l}\text { Muito } \\
\text { grossa }\end{array}$ & Grossa & Média & Fina & $\begin{array}{c}\text { Muito } \\
\text { fina }\end{array}$ & Total & Argila & Silte \\
\hline $\begin{array}{l}\text { Horizonte marrom e } \\
\text { bege arenoso (1) e (2) }\end{array}$ & PA 0-140 & 0,01 & 0,33 & 7,61 & 40,80 & 45,53 & 94,28 & 0,45 & 5,28 \\
\hline $\begin{array}{c}\text { Horizonte amarelo } \\
\text { arenoso (1c) }\end{array}$ & HA 30-45 & 0,03 & 0,27 & 6,77 & 34,79 & 47,48 & 89,34 & 1,61 & 9,05 \\
\hline $\begin{array}{c}\text { Horizonte verde } \\
\text { argiloso, mais ou } \\
\text { menos, cimentado (6) }\end{array}$ & В $190-280$ & 0,10 & 0,15 & 3,21 & 19,00 & 36,91 & 59,37 & 27,00 & 13,59 \\
\hline
\end{tabular}

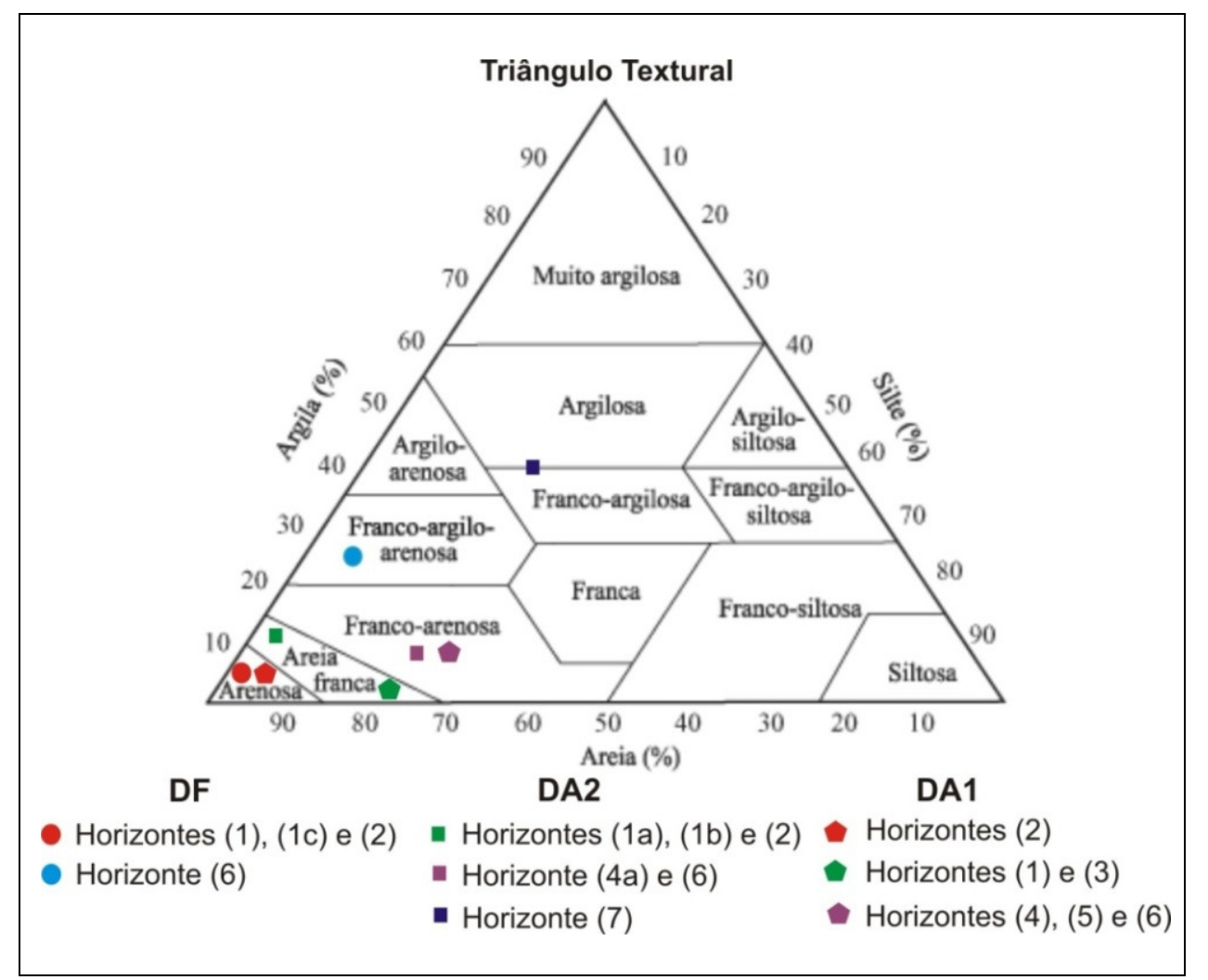

Figura 31 - Enquadramento dos horizontes nas classes texturais pelas porcentagens de areia, silte e argila (segundo triângulo textural apresentado por Lemos e Santos, 1992). 
Os horizontes (1), (1c) e (2) da Depressão Fechada com 89 a 94\% de areia se enquadram na classe textural arenosa. O horizonte (6), com $27 \%$ de argila, entra na classe textural franco-argilo-arenosa (Figura 31).

Na Depressão Aberta 2, nos pontos T8, T12 e T10 nos horizontes (7) e (6), e na Depressão Aberta 1, no horizonte (4), a fração argila é composta de caulinita e esmectita, e também por minerais primários, quartzo e mica (provavelmente ilita). Somente no ponto T1 da DA2, centro da depressão, no horizonte (7) não aparece mica, e no (6) o quartzo. Na DA1 aparece também o feldspato (Anexo 2).

$\mathrm{Na}$ Depressão Fechada, a fração argila do horizonte (6) é composta também por caulinta e esmectita, e pelo mineral primário quartzo (Anexo 2).

Em síntese, retêm-se os seguintes pontos das observações diretas dos solos, e de seus constituintes:

a) As Depressões Abertas 1 e 2 apresentam sequências de solos formadas por sucessões verticais de 6 horizontes, e a Depressão Fechada, e a que liga as duas Depressões Abertas, de 5 horizontes.

b) Todas as sequências apresentam dois grupos nítidamente identificáveis pela textura dos horizontes. De um lado, o grupo formado pelos horizontes superficiais e subsuperficiais com textura arenosa, e de outro, o grupo formado pelos horizontes profundos com textura areno-argilosa, argilo-arenosa a argilosa. A transição entre estes dois conjuntos é abrupta.

c) Esses dois conjuntos também se mantém nas análises de resistividade, isto é, o conjunto arenoso apresenta alta resistividade, e o conjunto areno-argiloso, argilo-arenoso a argiloso baixa resistividade.

d) Nota-se que as diferenciações entre horizontes são dadas, sobretudo pela cor, textura e consistência.

\section{6 - CARACTERÍSTICAS FÍSICO-QUÍMICAS DAS ÁGUAS}

A Tabela 7 apresenta as variáveis físico-químicas das águas estudadas nas Depressões Abertas 1 e 2, e na Fechada, e a Figura 32 mostra a localização dos coletores na Depressão Fechada. 
Na Depressão Aberta 1 a CE das águas do lençol freático é de $172 \mu \mathrm{S} / \mathrm{cm}$, com pH de 7,9, e nas águas superficiais a CE varia de 39 a $45 \mu \mathrm{S} / \mathrm{cm}$, com pH 6 . O redox, medido somente em águas superficiais, é de $94 \mathrm{mV}$ no início da estação seca (maio de 2010), e atinge $255 \mathrm{mV}$ em outubro de 2011, no final da estação seca e início da chuvosa. As temperaturas variam de 26 a $30^{\circ} \mathrm{C}$.

$\mathrm{Na}$ Depressão Aberta 2 o pH varia de 4,55 a 6,75, e a CE de 45 a $230 \mu \mathrm{S} / \mathrm{cm}$.

$\mathrm{Na}$ Depressão Fechada, de acordo com os períodos de medidas e os pontos de coleta, observa-se:

$\left.1^{\circ}\right)$ em maio de 2010, ao término da estação chuvosa, o valor da CE no ponto G1, próximo à cordilheira, é de $24 \mu \mathrm{S} / \mathrm{cm}$, nos pontos $\mathrm{G} 2$ e G3 é de $22 \mu \mathrm{S} / \mathrm{cm}$, no G4 sobe para $45,5 \mu \mathrm{S} / \mathrm{cm}$, e no centro da depressão, no $\mathrm{G} 6$, desce para $43 \mu \mathrm{S} / \mathrm{cm}$. $O$ $\mathrm{pH}$ das águas oscila de 5 a 5,6, exceto no ponto $\mathrm{G} 4$ onde é ligeiramente superior a 6.

As medidas de redox foram feitas nos dias 24 e 29/05/2010. No dia 24, o valor mais alto, $340 \mathrm{mV}$, aparece no ponto $\mathrm{G} 3$ a uns 70 metros da borda da depressão, e os mais baixos são encontrados no ponto G5, 190 mV, e no G6, 200 mV, localizados no centro da depressão. No dia 29 os valores redox variam de 180 a $250 \mathrm{mV}$, sendo de $180 \mathrm{mV}$ no centro da depressão, no ponto G6.

$2^{\circ}$ ) em agosto de 2010, na estação seca, os coletores estavam sem água nos pontos $\mathrm{G} 2$ e G5. A CE varia de $22,8 \mu \mathrm{S} / \mathrm{cm}$, no $\mathrm{G} 1$, início da cordilheira, a 46,8 $\mu \mathrm{S} / \mathrm{cm}$ em G6 no centro da depressão, ou seja, ela aumenta da borda em direção ao centro da depressão. O pH varia de 5 a 5,8, e os valores redox de 354 a $170 \mathrm{mV}$, de G3, próximo da borda, para o centro da depressão em G6.

3) em julho de 2011, início da estação seca, os valores da CE da água do lençol freático oscilam de 22 a $33 \mu \mathrm{S} / \mathrm{cm}$ de $\mathrm{G} 1$ a G5, e aumentam para $46 \mu \mathrm{S} / \mathrm{cm}$ no centro da depressão, no ponto G6. $\mathrm{O}$ pH é de 5,5 nos três primeiros pontos na proximidade com a cordilheira (G1, G2 e G3), e de 6 nos pontos em direção ao centro da depressão (G4, G5 e G6). O redox é de166 mV no G2, oscila entre 110 e $130 \mathrm{mV}$ até o ponto $\mathrm{G} 5$, e diminui para $80 \mathrm{mV}$ em G6.

4) em outubro de 2011, no início da estação chuvosa, a CE varia de 25 a $84,7 \mu \mathrm{S} / \mathrm{cm}$. Este valor corresponde ao coletor do ponto $\mathrm{G} 2$, localizado a 30 metros da cordilheira. No centro da depressão a CE da água varia de 33 a quase $40 \mu \mathrm{S} / \mathrm{cm}$. $\mathrm{O} \mathrm{pH}$ oscila em torno de 5,5, exceto no $\mathrm{G} 1$ que é de 6,4 . No ponto $\mathrm{G} 1$, no limite depressão/cordilheira, e no ponto G6, no centro da depressão, os valores redox são 
de 154 e 132 mV, e nos pontos G2, G3, G4 e G5 os valores oscilam de 209, 200 a $205 \mathrm{mV}$.

Tabela 7 - Resultados das medidas in situ das variáveis físico-químicas de águas superficiais e subsuperficiais das Depressões Abertas 1 e 2, Depressão Fechada e Baía.

\begin{tabular}{|c|c|c|c|c|c|c|}
\hline \multicolumn{7}{|c|}{ MEDIDAS IN SITU DAS VARIÁVEIS FÍSICO-QUÍMICAS DAS ÁGUAS } \\
\hline LOCAL & DATA & PONTOS & $\mathrm{CE}(\mu \mathrm{S} / \mathrm{cm})$ & $\mathrm{pH}$ & Temp ( 으) & $\begin{array}{c}\text { Redox } \\
(\mathrm{mV})\end{array}$ \\
\hline \multirow{3}{*}{ 充 } & SETEMBRO/2009 & Água do lençol & 172 & 7,9 & 26,3 & - \\
\hline & 29/MAIO/2010 & Água superficial & 45 & 6,03 & 29,8 & 94 \\
\hline & 05/OUTUBRO/2011 & Água superficial & 39,1 & 6,67 & 27 & 255 \\
\hline \multirow{4}{*}{ 弪 } & \multirow{4}{*}{ 02/SETEMBRO/2010 } & T1 (lençol $107 \mathrm{~cm}$ ) & 104 & 6,75 & - & - \\
\hline & & T4 (lençol $210 \mathrm{~cm}$ ) & 45 & 5,21 & - & - \\
\hline & & T3 (lençol $160 \mathrm{~cm}$ ) & 230 & 4,55 & - & - \\
\hline & & T8 (lençol $122 \mathrm{~cm}$ ) & 86 & 4,78 & - & - \\
\hline \multirow{30}{*}{ 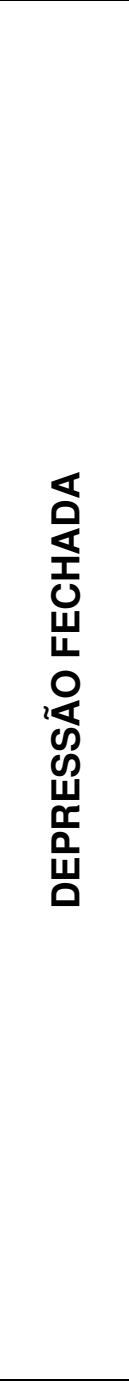 } & \multirow{6}{*}{ 24/MAIO/2010 } & G1 & 24 & 5,55 & 25,5 & 283 \\
\hline & & G2 & 22,2 & 5,63 & 23,4 & 220 \\
\hline & & G3 & 22,5 & 5,2 & 25,1 & 340 \\
\hline & & G4 & 32 & 6,25 & 24,2 & 277 \\
\hline & & G5 & 45,5 & 5,35 & 24 & 190 \\
\hline & & G6 & 43,2 & 4,9 & 22,7 & 200 \\
\hline & \multirow{6}{*}{ 29/MAIO/2010 } & G1 & - & - & - & 200 \\
\hline & & G2 & - & - & - & 215 \\
\hline & & G3 & - & - & - & 225 \\
\hline & & G4 & - & - & - & 250 \\
\hline & & G5 & - & - & - & 230 \\
\hline & & G6 & - & - & - & 180 \\
\hline & \multirow{6}{*}{ 29/AGOSTO/2010 } & G1 & 22,8 & 5,8 & 30 & 354 \\
\hline & & G2 & - & - & - & - \\
\hline & & G3 & 22,7 & 5,1 & 31,1 & 320 \\
\hline & & G4 & 30,4 & 5,81 & 30,4 & 245 \\
\hline & & G5 & - & - & - & - \\
\hline & & G6 & 46,8 & 5,07 & 28,3 & 170 \\
\hline & \multirow{6}{*}{ 13/JULHO/2011 } & G1 & 30 & 5,5 & 25,5 & 150 \\
\hline & & G2 & 22 & 5,75 & 25,5 & 166 \\
\hline & & G3 & 22 & 5,5 & 25,2 & 135 \\
\hline & & G4 & 32 & 6,17 & 25,5 & 110 \\
\hline & & G5 & 33 & 6,02 & 25,2 & 130 \\
\hline & & G6 & 46 & 6,05 & 26,2 & 80 \\
\hline & \multirow{6}{*}{ 06/OUTUBRO/2011 } & G1 & 40 & 6,4 & 30,7 & 154 \\
\hline & & G2 & 84,7 & 5,53 & 32,2 & 209 \\
\hline & & G3 & 25,8 & 5,76 & 31,2 & 209 \\
\hline & & G4 & 27,32 & 5,8 & 31,8 & 200 \\
\hline & & G5 & 33,4 & 5,68 & 32,1 & 205 \\
\hline & & G6 & 39,6 & 5,72 & 30,8 & 132 \\
\hline \multirow{3}{*}{$\underset{\infty}{\overleftarrow{\Phi}}$} & 24/MAIO/2010 & Água superficial & 54,6 & 7,3 & 24,1 & 210 \\
\hline & 29/AGOSTO/2010 & Água superficial & 175 & 6,74 & 29,9 & 75 \\
\hline & 06/OUTUBRO/2011 & Água superficial & 107 & 7,5 & 29,3 & 193,6 \\
\hline
\end{tabular}




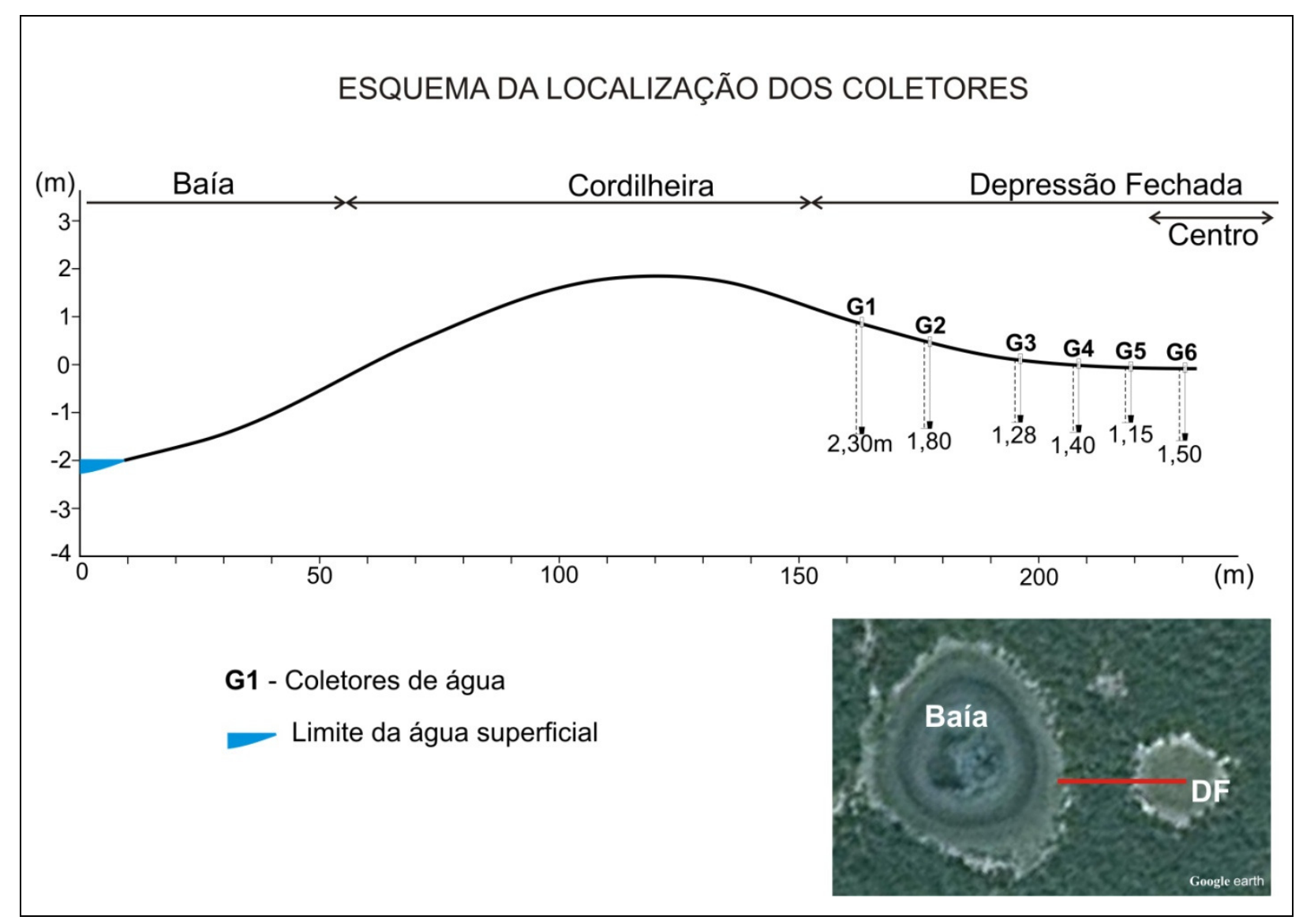

Figura 32 - Localização dos coletores na Depressão Fechada (G1 a G6).

Os valores de temperatura na água do lençol variam de 22 a $26^{\circ} \mathrm{C}$ nos períodos de término da estação chuvosa e início da seca, em maio de 2010 e julho de 2011 , e de 28 a $32^{\circ} \mathrm{C}$ na estação seca e início do período chuvoso, em agosto de 2010 e outubro de 2011.

Na Baía contígua à Depressão Fechada a CE das águas superficiais é de $54,6 \mu \mathrm{S} / \mathrm{cm}$ em maio de 2010 , de $175 \mu \mathrm{S} / \mathrm{cm}$ em agosto de 2010 , e de $107 \mu \mathrm{S} / \mathrm{cm}$ em outubro de 2011. O pH é de 7,3 em maio, e 6,74 em agosto de 2010, e de 7,5 em outubro de 2011. O valor do redox é de $210 \mathrm{mV}$ em maio, no final da estação úmida, de $75 \mathrm{mV}$ no mês de agosto, na estação seca, e de $194 \mathrm{mV}$ em outubro de 2011, início da estação úmida.

Em síntese, a Tabela 7 mostra que o valor da CE na Depressão Aberta 1 é maior nas águas do lençol freático, com pH levemente alcalino, do que nas águas superficiais, com $\mathrm{pH}$ ácido. $\mathrm{Na}$ Depressão Aberta 2 a água do lençol freático localizado no horizonte (7), ponto T3, apresenta o maior valor de CE, e pH ácido. 
$\mathrm{Na}$ Depressão Fechada nota-se uma leve tendência dos valores da CE aumentarem, do ponto $\mathrm{G} 1$, início da cordilheira, em direção ao ponto G6, centro da depressão no período monitorado. Os valores redox são mais baixos nos pontos próximos ao centro da depressão, e mais altos em direção à cordilheira, porém não seguem uma sequência decrescente, ou crescente, regular.

$\mathrm{Na}$ Baía as águas são mais concentradas no período seco, apresentando maiores valores de $\mathrm{CE}$ em relação ao periodo úmido.

\section{7 - MONITORAMENTO DO NÍVEL DA ÁGUA DO LENÇOL FREÁTICO ENTRE A DEPRESSÃO FECHADA E A BAÍA}

A Figura 33 apresenta o gráfico do monitoramento do nível da água do lençol freático entre o centro da Depressão Fechada e a borda da Baía localizada a SE. Este monitoramente foi contínuo, durante um ano hidrológico completo, de 08/10/2010 a 03/10/2011. Este intervalo inclui um período de cheia, de outubro de 2010 a abril de 2011 considerado excepcional, e um período de seca, de maio a final de setembro de 2011.

No início do monitoramento, em outubro de 2010, nota-se no gráfico que o nível da água do lençol freático na Depressão Fechada era mais alto do que o da Baía. No início da cheia, em março de 2011, ocorre uma inversão, o nível freático da Baía ultrapassa por alguns dias o da Depressão Fechada, e em seguida se inverte novamente, e assim permanece até 17 de junho de 2011, quando ocorre uma nova inversão, e o nível freático da Depressão fica abaixo do da Baía.

Em detalhe, observa-se que no período de 08/10/10 a 25/02/11 as respostas às chuvas são similares nas duas unidades, e o nível freático na Depressão Fechada é sempre mais alto, em aproximadamente $50 \mathrm{~cm}$, que o da Baía. A partir de meados de janeiro de 2011, os níveis freáticos sobem e não retornam ao nível inicial medido no final de 2010.

Dados de precipitação, fornecidos pelo pluviômetro instalado nas dependências da Fazenda Centenário, mostram que o total de chuvas nos três primeiros meses de 2011 foi de $1272 \mathrm{~mm}$, com $347 \mathrm{~mm}$ em janeiro, $254 \mathrm{~mm}$ em fevereiro, e $671 \mathrm{~mm}$ em março. Esse total foi maior do que a média anual de chuvas 
no Pantanal, que varia de 800 a 1200 mm (Galdino, et al., 2002), e isto indica uma pluviosidade excepcional.

A partir do dia 26/02/11, os níveis freáticos das duas unidades começam a subir rapidamente. Na Baía atinge seu ápice no dia 14/03, e ultrapassa em $80 \mathrm{~cm}$ o da Depressão Fechada. Neste intervalo de 17 dias, o nível do lençol freático da Baía passa de -160 para $130 \mathrm{~cm}$, ou seja, sobe $290 \mathrm{~cm}$, com velocidade média de 17 cm/dia. Na Depressão Fechada, o nível freático se estabiliza no dia 19/03/11 em um nível mais baixo, aproximadamente $50 \mathrm{~cm}$ acima do nível do solo. Neste intervalo de 22 dias o lençol passa de -90 para $54 \mathrm{~cm}$, equivalente a uma subida de $144 \mathrm{~cm}$, responsável por uma lâmina d' água de $50 \mathrm{~cm}$ de altura no centro da depressão.

A partir do dia 17 de março de 2011, o nível freático da Baía começa a descer rapidamente, e no dia 27 de março ele se posiciona abaixo do da Depressão Fechada, e assim permanece até 25 de junho. Nesse período ele se estabiliza, e desce lenta e progressivamente. Porém, durante dois meses e 18 dias, de 7/03 a 26/05/11, o nível freático da Baía permaneceu de 1,40 m a 0,10 $\mathrm{m}$ acima do nivel da superfície do solo. A velocidade de descida foi, em média, de 0,42 cm/dia. Nesse período o nível freático da Baía se manteve abaixo do da Depressão Fechada, e isto até o dia 16/06, quando se observa uma nova inversão, em que o nível freático da depressão volta a se posicionar abaixo do da Baía.

Por outro lado, nota-se que a partir do dia 19/03 o nível freático da Depressão Fechada começa a diminuir contínuamente até o dia 15/06, em uma velocidade média de 0,63 cm/dia, pois ainda há uma lâmina de água no centro da depressão. De 15/06 a 08/07 ocorre uma descida brusca do nível freático da depressão, de 0 a $-102 \mathrm{~cm}$ de profundidade, a uma velocidade média de $3,5 \mathrm{~cm} /$ dia. A partir daí, ele permanece, aproximadamente $70 \mathrm{~cm}$ mais baixo que o da Baía, e no final do monitoramento quase retorna ao seu nível inicial, diferentemente do da Baía que se mantém bem mais alto ao registrado no início do monitoramento. 


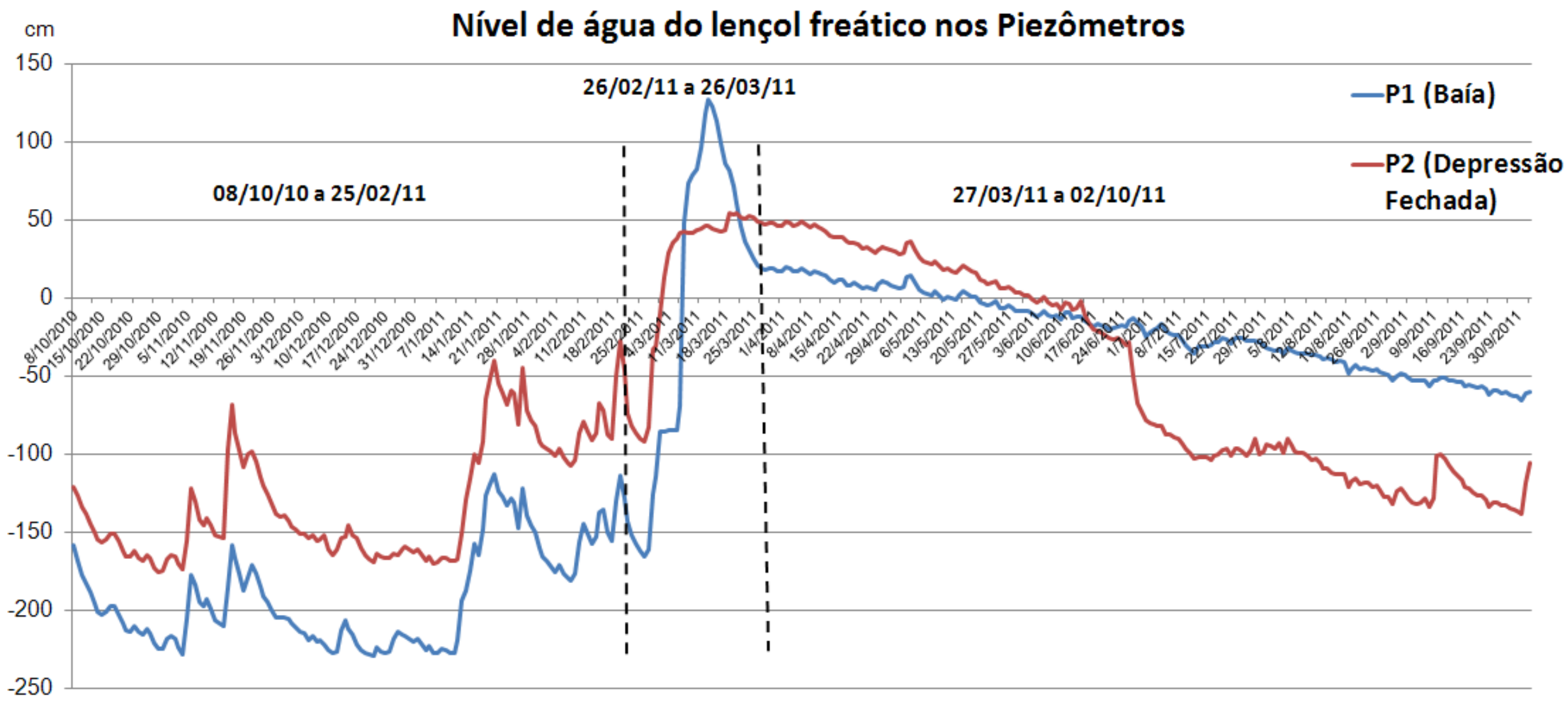

Figura 33 - Gráfico de monitoramento do nível do lençol freático entre a Depressão Fechada e uma Baía situada a SE. 


\section{5 - DISCUSSÕES DOS RESULTADOS}

\section{1 - METODOLOGIA}

Em primeiro lugar, apresenta-se dois aspectos da qualidade dos dados utilizados no decorrer do trabalho: A) de um lado, validação dos dados do EM38, B) de outro, a densidade dos pontos de medidas e os mapas da CEa resultantes.

\section{A) Validação dos dados do EM38}

A boa correlação linear entre os valores de CEa, medidos no campo e calculados a partir das medidas de resistividade de cada horizonte em laboratório, indica que a indução eletromagnética é um instrumento relevante para colocar em evidência variações verticais e laterais da cobertura pedológica. Pode-se inferir que as variações identificadas nos mapas de distribuição dos valores de CEa refletem variações reais do terreno, apesar dos valores serem baixos e pouco pronunciados, como nos mapas apresentados nas Figuras 22 e 23.

O teste realizado com o programa PCLoop, apresentado na Figura 21, mostra a existência de uma correlação linear aceitável entre os valores de condutividade elétrica aparente medidos no campo e os valores calculados. Entretanto, nota-se que a linha de regressão não passa pelo zero. Isto mostra que a calibração automática do zero no aparelho não está bem ajustada. Além disto, as gamas de valores são muito diferentes, e isto parece indicar que a inclinação da reta de calibração interna do aparelho também não se encontra bem calibrada. Consequentemente, os mapas elaborados a partir desses dados traduzem, efetivamente, variações da condutividade elétrica aparente do terreno, mas os valores absolutos não podem ser considerados. 


\section{B) Validação dos mapeamentos de CEa e localização dos pontos de medidas.}

A análise geoestatística destaca que os semivariogramas referentes aos dados das Depressões Fechada e Aberta 2 têm valor de alcance semelhante, $20 \mathrm{e}$ 25 metros, segundo o tipo de aparelho e as modalidades de tomadas das medidas, isto é, posição vertical ou horizontal. Pode-se dizer que a partir deste limite não há mais dependência espacial entre as variáveis, e que acima de 25, ou 30 metros não se pode fazer interpolação desses dados. Nota-se que o alcance é superior ao espaçamento mínimo mantido entre um ponto e outro de medida. Esta é uma primeira validação da qualidade das cartas produzidas. Além disto, se considera-se o valor de $10 \mathrm{~m}$ entre dois pontos de medidas, constata-se que esta distância corresponde a uma semivariância da ordem de um terço do patamar. Estes resultados confirmam a qualidade da extrapolação espacial da CEa utilizada nos mapas.

O efeito pepita na Depressão Fechada é nulo para os dados do EM38 em modalidade horizontal, e do EM31 na modalidade vertical, assim como para os do EM31 nas modalidades vertical e horizontal na Depressão Aberta 2. Isto indica, de um lado, que os aparelhos são estáveis, sem oscilações durante as medidas, e de outro, que a densidade de pontos foi suficiente para identificar a distribuição espacial da condutividade elétrica aparente nas áreas estudadas.

No caso dos mapeamentos com o EM38 na modalidade vertical, tanto na Depressão Fechada quanto na Aberta 2, aparecem efeitos pepita para distâncias inferiores a $3 \mathrm{~m}$. Considerando-se que nos outros levantamentos não houve oscilações durante as medidas, o efeito pepita não pode ser atribuído ao aparelho. Por outro lado, nos mapas das Figuras $22 \mathrm{C}$ e $23 \mathrm{E}$ as malhas para aquisição de dados se aproximaram, o que não foi o caso no campo. Portanto, os efeitos pepitas devem, neste caso, ser atribuídos à precisão de localização pelo GPS, que aproximou, no mapa, as linhas de pontos de coletas.

Em conclusão, os mapas elaborados são confiáveis em termos de variações nos valores de CEa, ainda que os valores absolutos não sejam. A melhoria neste tipo de mapeamento deve passar por: (1) uma calibração manual meticulosa dos aparelhos, e (2) um sistema de GPS diferencial para estudos mais detalhados, que exigem maior precisão. 


\section{2 - MAPA FISIOGRÁFICO}

A identificação das formas das principais unidades morfológicas que compõem a paisagem sul da Nhecolândia sublinha a complexidade morfológica desta área, de modo que seu entendimento vai além da interpretação de uma imagem de satélite.

Embora os principais objetivos da confecção do mapa fisiográfico tenham sido quantificar as pequenas depressões, e verificar os locais de suas ocorrências, é possível reter outras informações dessa etapa do trabalho.

Primeiramente, o mapeamento das lagoas permitiu constatar que observadas no conjunto, as lagoas apresentam um alinhamento NE-SW, sobretudo as situadas no quadrante NW e SW. Esta direção é concordante com os paleofluxos identificados no lobo 7 por Assine (2003), ou lobo 6 por Zani (2008), na Baixa Nhecolândia, e considerado o mais antigo do leque aluvial do Taquari.

A Vazante Castelo corta o mapa no sentido N-NE a S. Ela é formada por dois braços a montante, um na direção NE-SW, concordante com a dos paleofluxos, e o outro, na direção N-S, discordante com a dos paleofluxos. Esses braços ao juntarem-se configuram o trecho final, antes de deságuar no rio Negro, da Vazante Castelo, que se posiciona na direção única N-S, discordante da direção dos paleofluxos.

Em segundo lugar, as descrições das formas das lagoas, e dos contornos das vazantes colocaram o problema da definição, e da nomenclatura, das formas. percebeu-se, na literatura, que a denominação das formas das lagoas é geralmente resultante dos processos que as originaram. Neste sentido, encontra-se facilmente um inventário de formas de lagoas resultantes de processos fluviais, como canal abandonado, espiras de meandro, diques marginais, vale bloqueado, acreção lateral, oxbows lakes, dentre outros (Melack, 1984; Mousinho de Meis \& Tundisi, 1986; Ab'saber, 2006; França et al., 2008). Contudo, nenhum desses modelos de formas se aplicam às formas descritas nessa porção sul do leque aluvial do Taquari. Por isto, foi necessário buscar outras fontes para tentar denominá-las. A nomenclatura utilizada neste trabalho, baseou-se nos tipos de rugosidade superficial, e nas formas externas de nódulos propostas por Bullock et al. (1985 apud Castro, 2008), para estudos de micromorfologia de solos, assim como no grau 
de arredondamento e esfericidade das partículas, segundo Krumbein (1941), para estudos sedimentológicos. Esses modelos de forma foram os que melhor se adaptaram para descrever as formas identificadas nessa porção sul da Nhecolândia.

Em terceiro lugar, as unidades das pequenas depressões aparecem dentro de cordilheiras, de vazantes, ou como apêndices de lagoas, com distribuição espacial aleatória. No entanto, nos mapeamentos da CEa por indução eletromagnética (EM38 e EM31), percebe-se que as distribuições dos maiores valores de CEa na Depressão Aberta 2 configuram faixas com direção NE-SW (Figura 34). Esta direção é concordante com a dos paleofluxos dos lobos mais antigos do leque aluvial do Taquari, conforme apontaram Assine (2003) e Zani (2008).
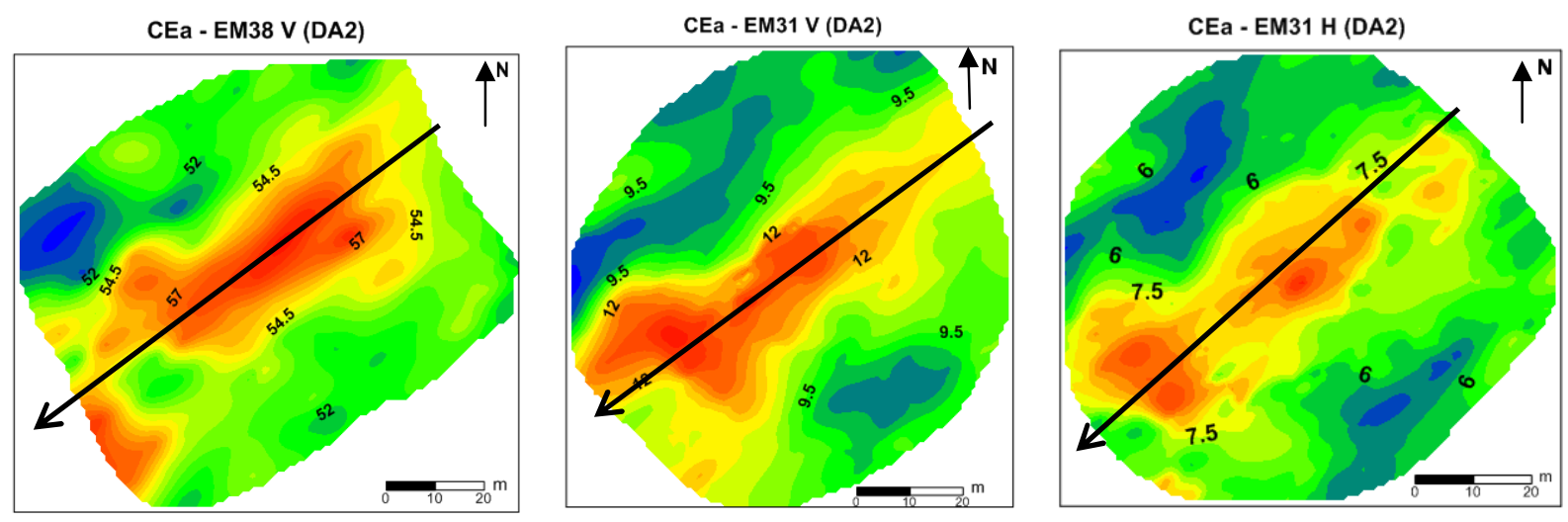

Figura 34 - Mapa de distribuição da CEa na Depressão Aberta 2. A seta mostra a direção NE-SW destacada pelos maiores valores de CEa.

Finalmente, na área mapeada estimou-se um total de 111 pequenas depressões, e isto mostra que essas unidades são representativas da paisagem sul da Nhecolândia. Em função dos locais onde ocorrem, dentro de vazantes ou isoladas por cordilheiras, apresentam funcionamentos hídricos distintos. Na primeira situação, encontram-se inseridas ao sistema aberto de drenagem, de onde recebem águas superficiais das vazantes em épocas de cheias, e diretamente das chuvas. $\mathrm{Na}$ segunda situação, isoladas do sistema de drenagem superficial, recebem águas somente dos fluxos subsuperficiais e diretamente das chuvas. 


\section{3 - MORFOLOGIA DOS SOLOS NAS PEQUENAS DEPRESSÕES}

Neste tópico serão discutidas as similaridades e as diferenciações nas coberturas pedológicas das três pequenas depressões estudadas.

\section{A) Similaridades morfológicas}

As três sequências de solos estudadas nas três depressões apresentam morfologias semelhantes, compostas por dois conjuntos de horizontes. Um conjunto superior formado pelos horizontes arenosos superficiais e subsuperficiais, e outro conjunto, inferior, formado pelos horizontes profundos areno-argilosos, argiloarenosos a argilosos, mais ou menos cimentados. $\mathrm{Na}$ base de todas as sequências aparece o horizonte (6) verde argiloso, mais ou menos cimentado, com forma ondulada, expressa por subidas e descidas suaves, e porcentagens de argila que variam de 10 a $27 \%$. Este horizonte era associado somente a ambientes alcalinos das lagoas salinas. No entanto, os estudos morfológicos realizados neste trabalho mostram que ele também ocorre nas pequenas depressões, porém menos desenvolvido que nas salinas, onde ele é mais espesso, com elevações mais pronunciadas, e um maior grau de cimentação pela sílica amorfa, conforme descrito por Barbiero, et al. (2002), Silva et al. (2004), Furquim (2007) e Martins (2012).

Os horizontes superficiais arenosos escuros, os subsuperficiais bege arenosos, e os horizontes cinza areno-argilosos identificados nas peqenas depressões também se assemelham a horizontes descritos por Sakamoto (1997), Rezende Filho (2006) e Furquim (2007) em outras unidades morfológicas, baías, vazantes, cordilheiras e banhados, de outras porções da Baixa Nhecolândia.

\section{B) Similaridades de constituintes}

Os dados de texturas permitem distinguir nas sequências de solos estudadas os horizontes que compõem cada um dos conjuntos identificados. O primeiro 
conjunto composto pelos horizontes arenosos (1), (1a), (1b), (1c), (2) e (3) de superfície e subsuperfície, que se enquadram nas classes de textura arenosa e areia-franca; e outro conjunto formado pelos horizontes profundos (4), (4a), (5), (6) e (7), com teores em argila entre 10 a $40 \%$, cuja textura oscila entre as classes franco-arenosa, franco-argilo-arenosa, franco-argilosa e argilosa.

Os argilominerais identificados na fração argila dos horizontes nas sequências de solos são, principalmente, a caulinita, a esmectita e a ilita. Nas Depressões Abertas 1 e 2, além destes também aparecem minerais primários como mica, provavelmente a ilita acima mencionada, feldspato e quartzo. Nas lagoas salinas estudadas por Furquim (2007) e Martins (2012) também foram identificadas esmectitas, caulinitas e ilitas na fração argila.

$O$ agenciamento entre esses dois conjuntos de horizontes, os arenosos de superfície e subsuperfície e os argilo-arenosos profundos, é responsável por uma ruptura da permeabilidade, que vai comandar os fluxos subsuperficiais da água.

Estes dois conjuntos de horizontes, definidos pela textura, são igualmente mantidos pelos valores de resistividade obtidos nas análises dos horizontes, de um lado, o conjunto de horizontes com valores altos de resistividade, arenosos; de outro, o conjunto de horizontes com baixos valores de resistividade, areno-argilosos, argilo-arenosos a argilosos. Se considerarmos os horizontes mais resistivos aqueles que apresentam maior permeabilidade, isto comprova que a organização da cobertura pedológica nas pequenas depressões propicia uma ruptura hídrica no contato entre esses dois conjuntos de horizontes.

\section{C) Diferenciações pedológicas dos horizontes}

Três aspectos serão abordados neste item: (1) a redistribuição do ferro: (a) na Depressão Fechada, (b) na sequência que liga as duas Depressões Abertas, (c) na Depressão Aberta 2; (2) a redistribuição da matéria orgânica na Depressão Aberta 1; (3) a presença do horizonte argiloso na Depressão Aberta 2. 


\section{I - Redistribuição do ferro}

A Depressão Fechada, e a elevação entre as Depressões Abertas 1 e 2, apresentam um regime hídrico particular, pois na maior parte do ano estão sem água, que se restringe sòmente ao período de cheia. Neste contexto, a dinâmica do ferro pode ser explicada a partir do coletor instalado na Depressão Fechada.

No período seco, os valores da CE nas águas do lençol freático da Depressão Fechada variam de 22 a 46,8 $\mu \mathrm{S} / \mathrm{cm}$, e no início, até o fim, da estação úmida de 22,2 a $84,7 \mu \mathrm{S} / \mathrm{cm}$, ou seja, não há alterações de valores significativas em função das estações secas e úmidas. Estes valores aumentam progressivamente do início da cordilheira ao centro da depressão, o que sugere uma tendência à concentração de elementos no centro da depressão.

Esta tendência pode ser avaliada pelo Diagrama Eh-pH do ferro (Pourbaix) que indica, a partir dos dados de redox e de $\mathrm{pH}$, quais formas do ferro, reduzida $\mathrm{Fe}^{2+}$ ou oxidada $\mathrm{Fe}(\mathrm{OH})_{3}$, predominam em um determinado local, neste caso no centro da depressão.

$\mathrm{Na}$ Depressão Fechada os valores redox variam de 0,57 a $0,29 \mathrm{~V}$, e o de $\mathrm{pH}$ de 4,9 a 6,4, que mostram que as soluções são ligeiramente ácidas. Estes valores distribuídos no diagrama se situam entre os domínios de predominância de duas formas do ferro, uma solúvel, $\mathrm{Fe}^{2+}$, outra sólida, $\mathrm{Fe}(\mathrm{OH})_{3}$ (Figura 35).

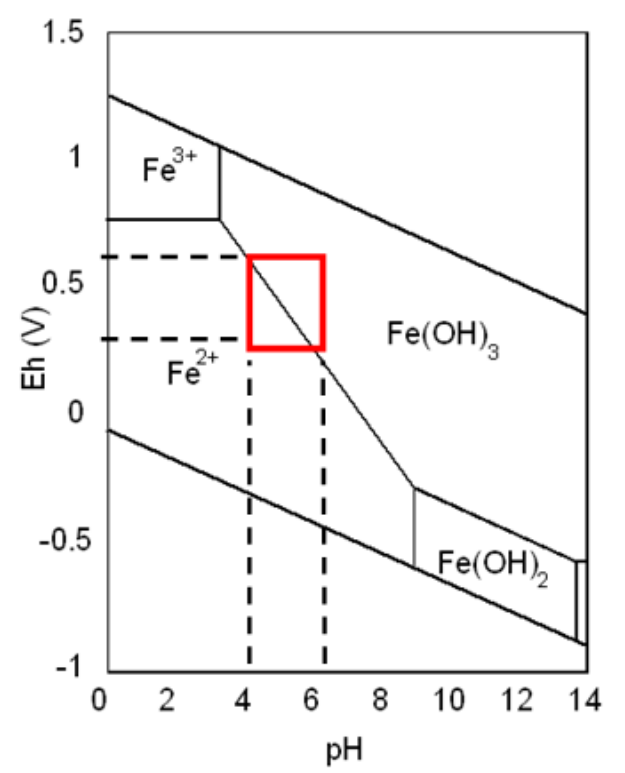

Figura 35 - Diagrama Eh-pH do ferro (simplificado de Pourbaix) 
Assim, em profundidade e durante a estação seca, as condições físicoquímicas do lençol evoluem em um domínio de $\mathrm{pH}$ e redox que favorecem a solubilização do ferro sob a forma $\mathrm{Fe}^{2+}$. Nesta estação, o lençol é baixo e um efeito de concentração das soluções pode ser observado em direção ao centro da depressão, provavelmente favorecida pela evaporação. A saída de água do centro da depressão ocorre por capilaridade. Assim, durante a ascensão capilar da solução, as condições se oxidam e o ferro precipita, e se imobiliza nas partes superiores do perfil (Figura 36). Efetivamente, a diferenciação do horizonte (2) ocorre pelo desenvolvimento do horizonte (1c) amarelo arenoso (Foto 7), circunscrito ao centro da Depressão Fechada, ligado à presença do ferro que modifica a cor, que passa de 7.5YR 7/3 para 10YR 4,5/6, e ao precipitar forma nódulos na base do horizonte.
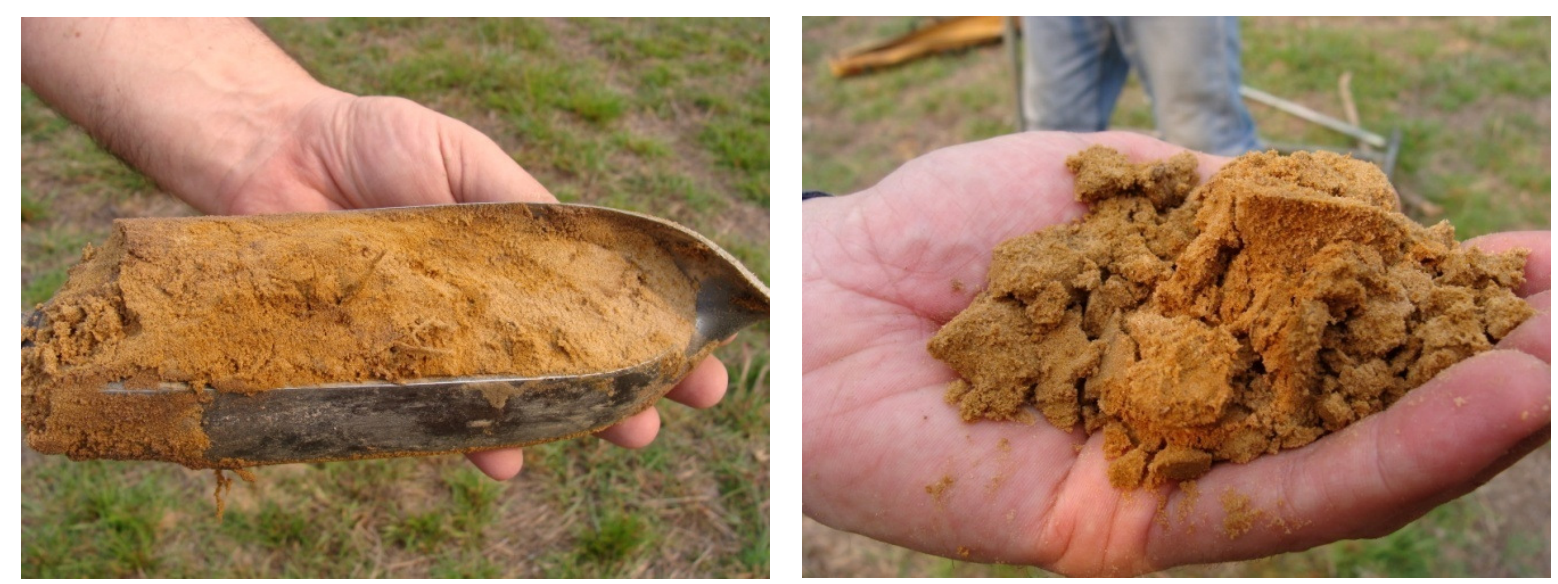

Foto 7 - Horizonte (1c) amarelo arenoso localizado no centro da Depressão Fechada.

$\mathrm{Na}$ estação chuvosa, as soluções circulam rapidamente, mas são, provavelmente, muito mais oxigenadas, e as condições não permitem remobilizar o ferro que se mantém sob a forma $\mathrm{Fe}(\mathrm{OH})_{3}$. Esta alternância de condições redox, decorrentes das oscilações entre períodos úmidos e secos, também pode ser aplicada à acumulação de ferro observada na sequência de solos entre as Depressões Abertas 1 e 2. Neste caso, o ferro também influi na cor e na presença de nódulos dentro e na base do horizonte. 


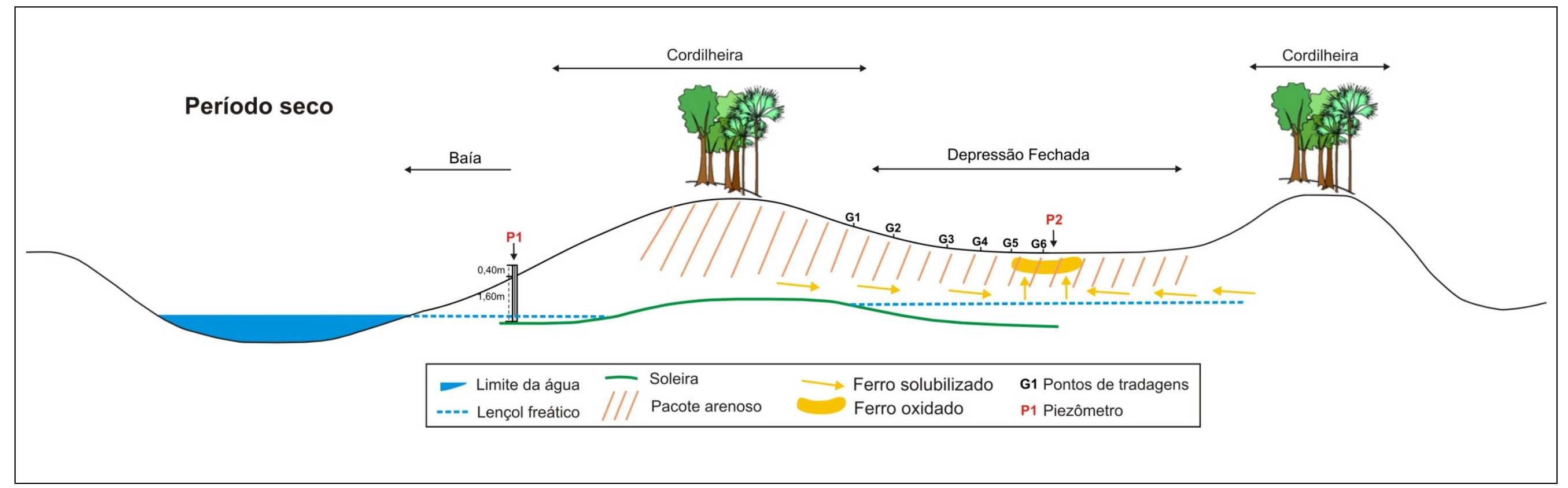

Figura 36 - Desenho representativo do processo de redistribuição de ferro na Depressão Fechada. 
$\mathrm{Na}$ Depressão Aberta 2, o horizonte (7) argiloso apresenta coloração variegada, consistência plástica quando molhado, e grande quantidade de volumes secos avermelhados de ferro, duros a extremamente duros quando seco (Foto 8). Estes volumes parecem estar se formado pelo mesmo processo que ocorre na Depressão Fechada, por variações de fases de umedecimento e secagem alternadas, ligadas às oscilações do lençol freático, que levam a uma redução e oxidação do ferro permitindo sua remobilização, e concentração sob forma de nódulos. Estas características aproximam o horizonte (7) dos horizontes plínticos descritos na porção norte do Pantanal, em Barão de Melgaço (Beirigo, 2008). Segundo este autor, durante o período de inundação da planície pantaneira, a mobilização do ferro leva à sua segregação, e à formação de zonas enriquecidas de ferro. Ao ser reoxidado o ferro precipita na forma de óxido (hematita), oxi-hidróxidos (goethita), e outras formas de baixo grau de cristalinidade (ferrihidrita), formando revestimentos, mosqueados e nódulos, as plintitas.
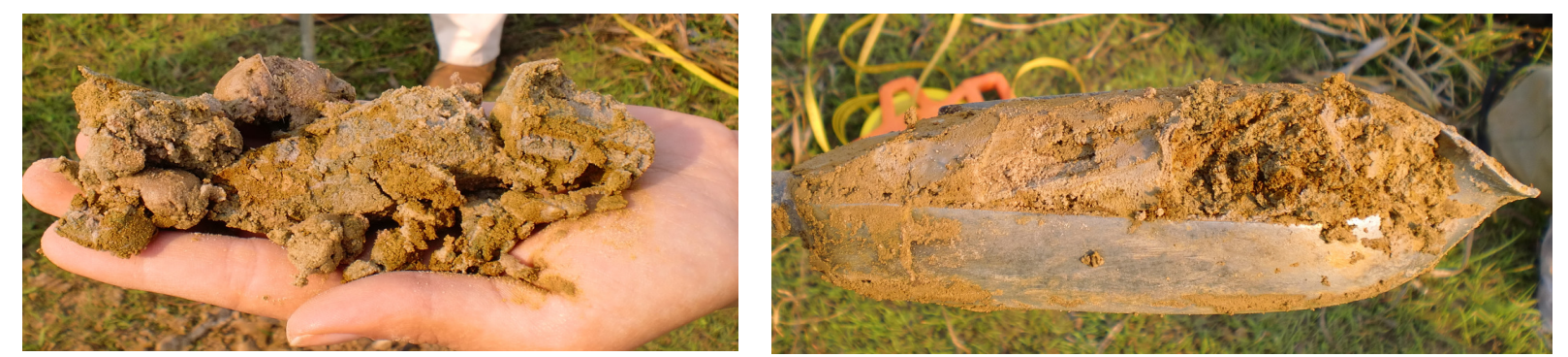

Foto 8 - Horizonte (7) argiloso com manchas avermelhadas localizado na Depressão Aberta 2.

\section{Il - Dinâmica da matéria orgânica}

As principais diferenciações pedológicas observadas na Depressão Aberta 1 dizem respeito ao forte constraste de cor entre os horizontes (2) e (3), e aos veios escuros e amarelo-avermelhados, de matéria orgânica e ferro, que saem do horizonte (3) em direção ao (4).

O horizonte (2) apresenta areia lavada, cor esbranquiçada (10YR 7,8/2), textura arenosa com mais de $90 \%$ de areia, estrutura maciça, e forte contraste de 
cor com o horizonte (3). Os dados analíticos mostram que do horizonte (1) para o (2) a argila passa de 7,46 para $1,87 \%$, o silte de 14 para $7,18 \%$, e a matéria orgânica de 3,46 para $0,17 \%$. Estes dados, somados às características morfológicas, indicam perda de materiais no horizonte (2), que migram para o (3), e deste para o (4). A transição entre os horizontes (2) e (3) é interdigitada, com nítidas manchas brancas de areia lavada na matriz escura (10YR 3/2) do horizonte (3). Estas manchas são também indicadoras de processos de perda neste horizonte (Figura 37). No horizonte (3) a porcentagem de argila sobe para $8,42 \%$, e a matéria orgânica para $1,47 \%$.

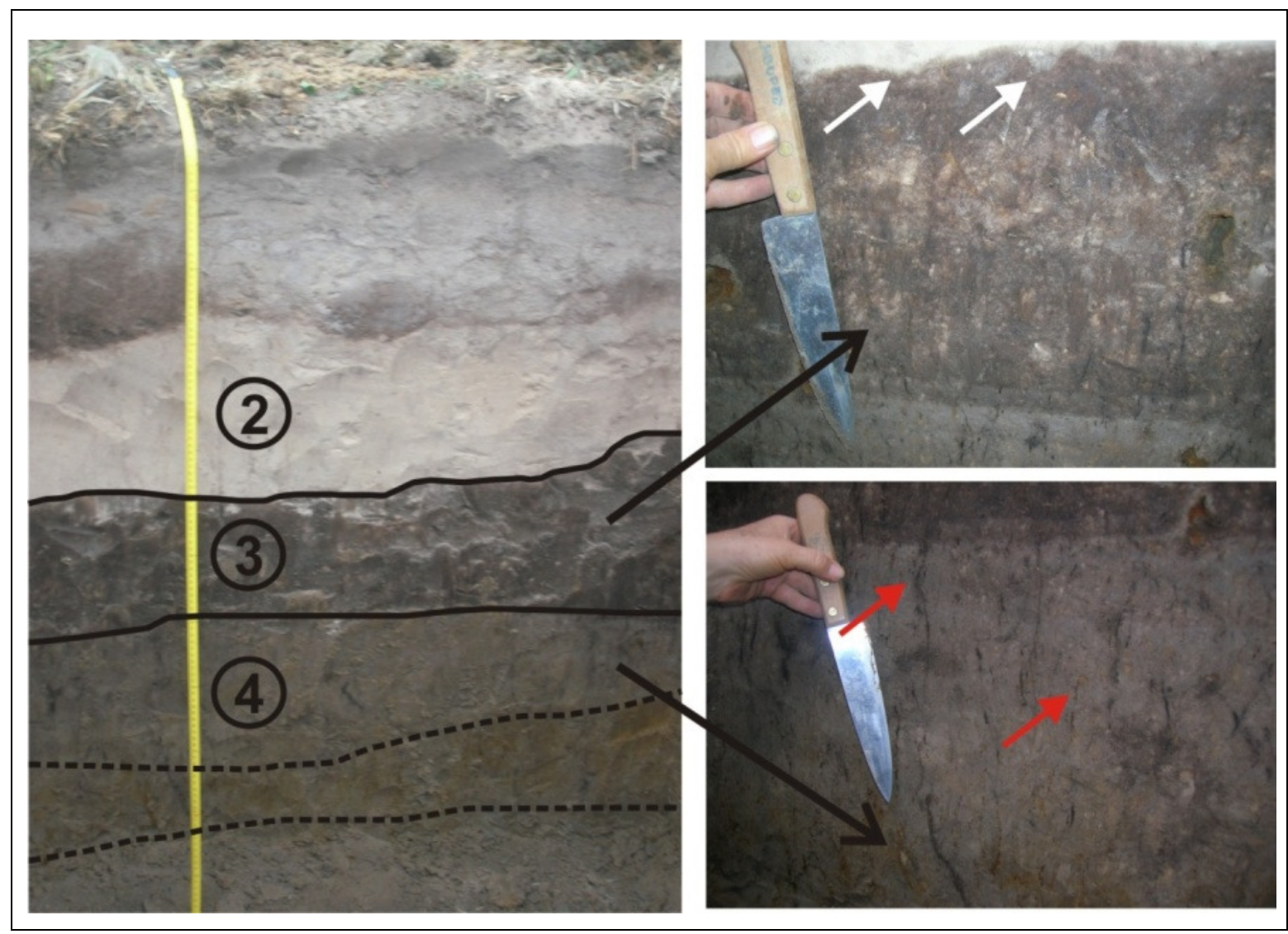

Figura 37 - Foto da trincheira localizada no centro da Depressão Aberta 1. As setas brancas mostram a interdigitação dos horizontes (2) e (3), e manchas brancas de areia lavada no horizonte (3). As setas vermelhas indicam a migração da matéria orgânica, em veios, e do ferro do horizonte (3) para o (4).

O horizonte (4) tem cor escura (5Y 5/1), é areno-argiloso, estrutura maciça, e apresenta porcentagens mais altas do que o horizonte (3), de argila, com 10,24\%, 
de silte, 10,44\%, e de matéria orgânica, com 1,55\%. Nota-se também que na base deste horizonte aparece uma faixa ondulada com concentração de ferro, porém não suficiente para diferenciar um horizonte.

Segundo Bueno (2009) os Podzóis, atualmente classificados como Espodossolos (Embrapa, 2006) apresentam duas categorias de horizontes: (1) os horizontes superiores eluviais que compreendem horizontes enriquecidos em resíduos orgânicos, do tipo Mor ( $L, O, A E)$ e os horizontes minerais álbicos $(E)$, sem coesão, e essencialmente constituídos por quartzo; e (2) os horizontes inferiores iluviais (Bh, Bhs e Bs) enriquecidos em compostos orgânicos ácidos que alteram os minerais de argila e formam os complexos organo-metálicos. Esta distribuição indica os mecanismos de perda (eluviação) e de acumulação (iluviação).

O principal mecanismo de formação dos podzóis, em ambiente ácido, é a ação complexante dos ácidos orgânicos, que criam condições favoráveis para a mobilização do $\mathrm{Fe}$, do $\mathrm{Al}$ e da matéria orgânica. O resíduo desta alteração agressiva é o quartzo, constituinte quase exclusivo do horizonte $E$ (Bueno, 2009).

Portanto, para que o processo de podzolização possa ser considerado os solos devem apresentar horizontes espódicos abaixo dos eluviais organo-minerais $(A, A E)$, ou minerais $(E)$, e mostrar evidências de acumulação de matéria orgânica e de metais (Lundström et al., 2000 apud Nascimento et al., 2010).

O conjunto das características morfológicas identificadas no solo da Depressão Aberta 1, e as análises feitas, condizem com o quadro apresentado pelos autores acima citados. Em outros termos, permitem inferir que as diferenciações dos horizontes ocorrem pela formação de um horizonte eluvial (2), que pode ser assimilado a um horizonte $\mathrm{E}$, concomitante à geração de horizontes iluviais, o horizonte (3), como um Bhs/E, pois também está sendo afetado pelo processo de eluviação, e o horizonte (4) como um Bhs, cuja base apresenta um "proto" Bs pela maior concentração de ferro, mas ainda incipiente para definir um horizonte. Portanto, nesta pequena depressão (DA1) a redistribuição da matéria orgânica, e do ferro, conduz a uma diferenciação de horizontes tipo podzol (Figura 38). 


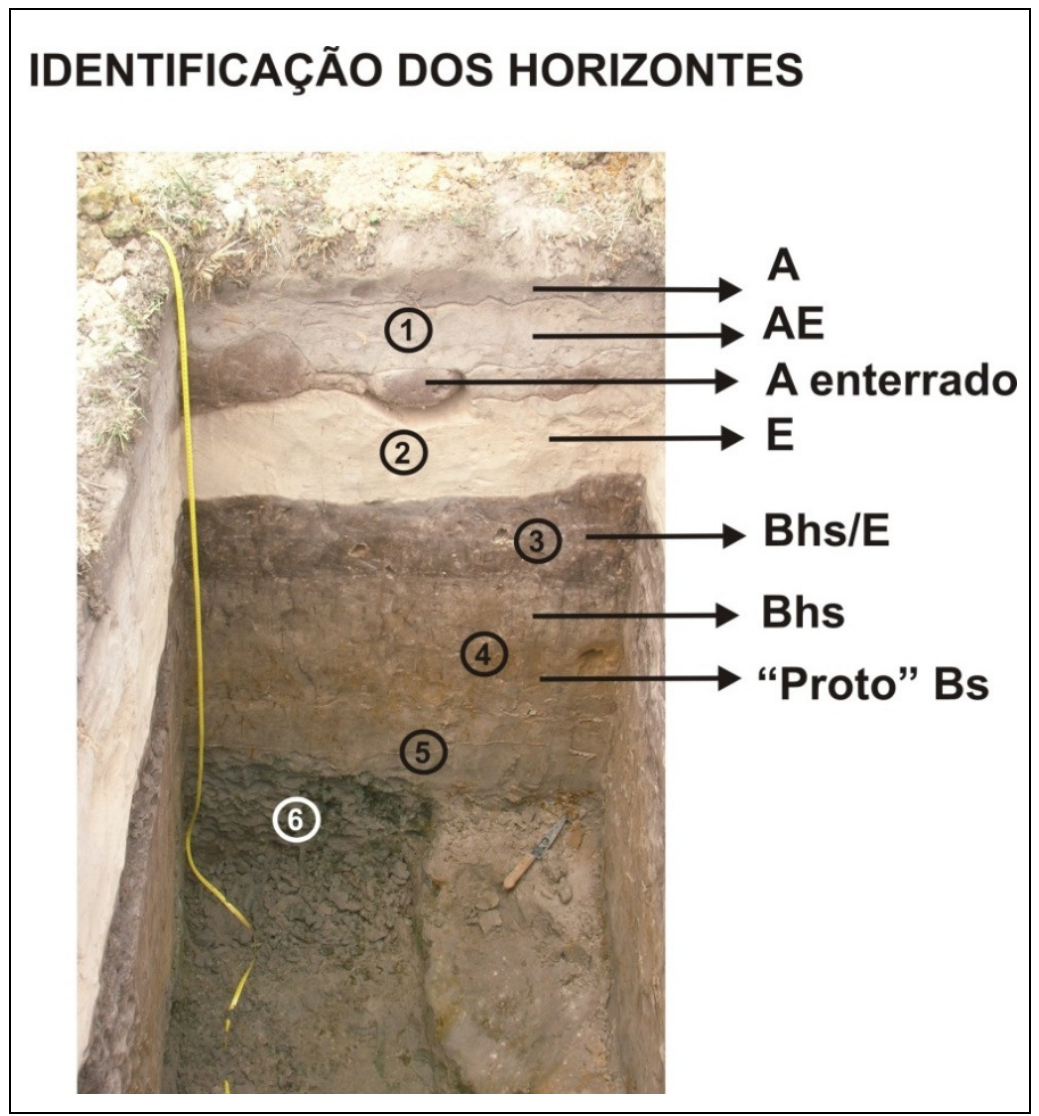

Figura 38 - Identificações dos horizontes na trincheira da Depressão Aberta 1.

III - Variações no solo não relacionadas às diferenciações pedológicas nas depressões

Os mapas confeccionados por indução eletromagnética destacam que os maiores valores de CEa configuram faixas que cortam a Depressão Aberta 2 na direção NE-SW. As observações diretas da cobertura pedológica mostram que essas faixas correspondem à presença do horizonte argiloso (7), com 40\% de argila, que se situa entre 1,20 a 2,80 m de profundidade aproximadamente.

A distribuição espacial deste horizonte não é concordante com a topografia atual do terreno, pois, além de estender-se da borda até o centro da depressão, ele também aparece ao exterior dela, cortando portanto, as linhas topográficas da depressão. Isto indica, provavelmente, que o horizonte (7) não se insere nas diferenciações pedológicas associadas à formação ou ao funcionamento atual da depressão. 
Levando-se em conta que esse horizonte corresponde à faixa de direção NESW formada pelos maiores valores de CEa na Depressão Aberta 2, constata-se, como assinalado acima, que ele é concordante com a direção predominante no lobo 7, o mais antigo do leque aluvial do Taquari (Assine, 2003; Zani, 2008). Este fato permite levantar a hipótese de que esse horizonte é uma herança de processos sedimentares anteriores à formação da depressão. Isto também indica que esse braço terminal da Vazante Castelo, onde a depressão se localiza, está atualmente cortando antigas estruturas sedimentares, sendo portanto posterior ao lobo 7 .

\section{D) CEa, morfologia e resistividade dos solos}

Os mapeamentos realizados por indução eletromagnética nas Depressões Aberta 2 e Fechada apresentam configurações diferenciadas dos maiores valores de CEa. Como salientou-se acima, na Depressão Aberta 2 esses valores formam uma faixa continua, que corta a depressão no sentido NE-SW, do centro a uma das bordas da depressão, e refere-se ao horizonte (7) argiloso, que apresenta 40\% de argila, e resistividade de 43 ohm.m. Na Depressão Fechada, ao contrário, esses valores tendem a formar um anel descontínuo, e pontos isolados a NE e SW nas proximidades da cordilheira (EM38-H e V, e EM31-V), e no centro da depressão (EM38-H).

Em particular, na Depressão Fechada, as manchas que apresentam valores mais altos de CEa também estão ligadas aos horizontes mais argilosos. A forma destas manchas tendem a formar um anel descontínuo no centro da depressão, e se assemelham com as configurações dos altos valores de CEa identificadas em lagoas salinas, como a Salina do Meio e a Salina Verde (Furquim, 2007; Martins, 2012). Estas salinas também apresentam o mesmo zoneamento da CEa em forma de aneis descontínuos, um localizado no entorno imediato das salinas, ligado ao horizonte orgânico superficial, e outro localizado no limite da praia com a cordilheira, referente ao horizonte verde argilo-arenoso cimentado. Em direção à cordilheira, assim como nas pequenas depressões, os valores da CEa tendem a diminuir concomitante a um aumento gradativo da topografia. 
Os mapas de CEa salientam a influência da textura dos horizontes, sobretudo da presença de argilominerais, da matéria orgânica e do ferro, nas respostas dos aparelhos ao medir a CEa no terreno. Como a resistividade é a grandeza inversa da condutividade elétrica, mostra-se também essa influência nos resultados dos testes de resistividade dos horizontes feitos em laboratório, pois os argilominerais, a matéria orgânica e o ferro agregam as partículas, e facilitam a condução da eletricidade (Becegato \& Ferreira, 2005; Nascimento et. al., 2004).

\section{4 - DINÂMICA DAS ÁGUAS NAS DEPRESSÕES}

Neste tópico serão abordadas as discussões referentes ao monitoramento do nível do lençol freático realizado entre a Depressão Fechada e a Baía, e também as observações de campo nas Depressões Abertas 1 e 2 sobre a dinâmica superficial das águas em perídos secos e úmidos.

\section{A) Monitoramento do nível freático na Depressão Fechada e na Baía}

\section{I - Soleira hídrica}

Pelos levantamentos bibliográficos realizados no decorrer deste trabalho, mostrou-se que o funcionamento hidrológico de algumas unidades da paisagem da Nhecolândia é comandado por um sistema de soleiras. Este sistema se desenvolve entre as lagoas, e determina a direção dos fluxos subsuperficiais de águas (Barbiero, et al., 2007, 2008). Este sistema é formado por horizontes argiloarenosos, mais ou menos cimentados pela sílica amorfa, e mais ou menos endurecidos. Este também é o caso nas depressões aqui estudadas.

Várias observações permitem mostrar que ocorre uma fragmentação do lençol freático na estação seca. As Depressões Abertas 1 e 2 são separadas por apenas $90 \mathrm{~m}$, mas o nível da água do lençol freático é diferente em cada uma delas. Do mesmo modo, o nível da água do lençol entre os piezômetros P1 e P2 difere de 
$50 \mathrm{~cm}$ aproximadamente, embora sendo relativamente estável ao longo de vários dias (exemplo na Figura 40, período seco). Estas diferenças do nível da água traduzem uma fragmentação do lençol freático, comandada pelo sistema de soleira que é decorrente da morfologia dos horizontes argilo-arenosos em profundidade, que apresenta ondulações mais ou menos pronunciadas.

Entre a Depressão Fechada e a Baía, o nível do lençol nos pontos mais baixos, 3/11, 10/12 e 20/12/2010, permitem inferir a altura da soleira a 1,70 m de profundidade. Essa altura foi estimada levando-se em conta o ponto de referência aqui adotado, que foi o nível do solo no centro da Depressão Fechada. Nestas condições, o lençol da Depressão Fechada é isolado, e pela evaporação sofre uma pequena concentração em direção ao centro da depressão, como indicam os valores de condutividade elétrica que aumentam ligeiramente de G1 a G6. Lembrando-se que nestas condições é que o ferro se acumula no centro da Depressão Fechada (Figura 36).

Nota-se que após dezembro 2010, os níveis da água permanecem superiores à altura da soleira, que consequentemente deixa de ter influência nas transferências laterais, que passam a ocorrer no conjunto superior de horizontes arenosos, permeáveis.

O mapeamento da CEa realizado na cordilheira, com o EM31 em modalidade vertical que tem maior sensibilidade de prospecção a partir de 2 metros de profundidade (Figura $23 \mathrm{~F}$ ), não detectou essa soleira. Isto está, provavelmente, ligado à forma e à altura da elevação da soleira, que pode ser muito suave ou muito pronunciada.

$\mathrm{Na}$ Depressão Fechada, dos pontos $\mathrm{G} 6$ ao $\mathrm{G} 1$, a espessura entre o topo dos horizontes arenosos superficiais (1) e (2), e o topo da soleira, horizonte (6) profundo, é constante, de 1,50 metros aproximadamente. Na cordilheira, essa espessura passa a ser de 1,70 metros, e em direção à Baía diminui para 1,60 metros. Essas pequenas variações de espessura mostram que a soleira possui uma elevação suave, e sua forma e altura não são suficientes para provocar uma mudança abrupta na resposta do EM31.

A Figura 39 apresenta a forma e a localização dessa soleira, . Este desenho refere-se ao dia 29/10/10 do gráfico de monitoramento, que apresenta os níveis mais baixos do lençol freático na Depressão Fechada e na Baía. 


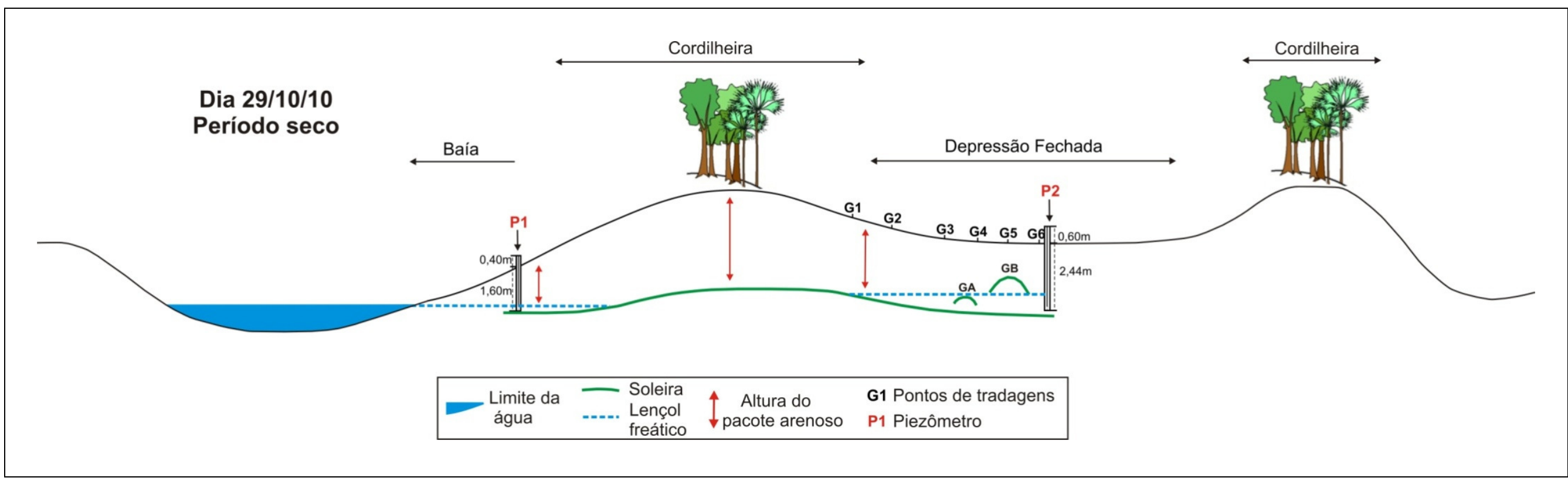

Figura 39 - Localização da soleira na Depressão Fechada: pontos (GA) e (GB) elevações do horizonte (6) verde argiloso, localizado por tradagens. Este esquema se baseia no nível freático do dia 3/11/10 (Gráfico, Figura 32). 
Il - Funcionamento hídrico da Depressão Fechada durante uma cheia excepcional

Considerando-se as variações do nível do lençol freático, percebe-se duas situações:

$\left.1^{a}\right)$ a entrada de água superficial na Baía pela vazante, que causou uma elevação de seu nível freático a ponto de ultrapassar a soleira hídrica, e um fornecimento de água, via subsuperfície, para a Depressão Fechada; 2a $)$ a desconexão das águas superficiais da Baía com as da vazante, e a saída de água, por fluxos subsuperficiais, da Depressão Fechada em outras direções.

De acordo com o gráfico, as chuvas começam a ter uma influência no lençol freático após a primeira semana de janeiro. Os lençóis, na Baía (P1), e no centro da Depressão Fechada (P2), respondem rapidamente aos eventos chuvosos com uma forte oscilação até aproximadamente 25 de fevereiro de 2011. Após esta data, as oscilações são muito atenuadas pelo fato dos lençóis terem ultrapassado o nível da superfície do solo.

Em março, observa-se uma subida abrupta, mais de $2 \mathrm{~m}$, do nível da água na Baía (P1), concomitante a uma subida de apenas $1 \mathrm{~m}$ na Depressão Fechada (P2). Este aspecto da curva indica que a Baía foi invadida pelas águas da vazante, mas que o nível não subiu o suficiente para ultrapassar a cordilheira que a separa da Depressão Fechada (Figura 40 A). Como o nível da água na Baía se elevou mais que na depressão, esta passa a ser alimentada subsuperficialmente pelas águas da Baía, sob a cordilheira. Esta entrada adicional de água forma uma lâmina d'água superficial de $50 \mathrm{~cm}$ de altura no centro da depressão.

A descida do nível da água em P1 é tão rápida quanto a subida, de 14 a 27 de março 2011, ou seja, $1 \mathrm{~m}$ em 13 dias. A partir do dia 27/03, interrompe-se os fluxos superficiais entre a Baía e a vazante, que passam a ser feitos na cobertura arenosa, subsuperficialmente. Na curva isto se traduz por uma ruptura na velocidade de descida do nível da água de $\mathrm{P} 1$, a partir da qual passa a ser menos rápida que a velocidade de descida do nível freático da depressão. A descida do nível freático da Baía permanece regular durante os 6 meses seguintes, fim do monitoramento. Isto indica fluxos contínuos, e constantes, através da cobertura arenosa (Figura $40 \mathrm{~B}$ ).

Inicialmente, o nível freático da Depressão Fechada é mais elevado do que o da Baía, e os fluxos saem, portanto, da depressão. Em 16 de junho de 2011, a 
lâmina d'água no centro da Depressão Fechada seca, e o nível da água se instala sob o da Baía. Novamente os fluxos se invertem, e a depressão passa a ser alimentada pelas águas da Baía. Entretanto, percebe-se que o nível da água continua descendo rapidamente na Depressão Fechada, e isto indica que a água não se acumula mas apenas transita por ela. Provavelmente, essa água escoa subsuperficialmente em direção às áreas mais baixas topograficamente, que se situam do lado oposto da Baía, ao norte da Depressão Fechada (Figura 41).

O fato do nível freático na Depressão Fechada descer rapidamente a partir de 16 de junho de 2011, não significa um aumento do fluxo. Trata-se unicamente de uma diminuição do volume de poros ocupado pela água no conjunto de horizontes arenosos superficiais, que era de $100 \%$ antes do dia 16 de junho, quando o nível da água estava mais alto que o nível do solo, e que se reduz consideravelmente, em torno de $30 \%$, durante o processo de esvaziamento da Depressão Fechada, quando se inicia a secagem desses horizontes.

Chama-se a atenção ao fato da situação hidrológica em setembro de 2011 ser totalmente diferente da situação de setembro de 2010, com um reservatório de água na Baía que não retomou sua situação inicial. Isto demonstra que um ano hídrico excepcional, como o da estação chuvosa de 2011, pode influenciar o regime hídrico das lagoas ao redor das vazantes durante um período de tempo não negligenciável.

O tipo de funcionamento hídrico observado na Depressão Fechada é diametralmente oposto ao das lagoas salinas, que com a subida do lençol freático recebem águas por fluxos subsuperficiais, que nelas permanecem retidas (Sakamoto, 1997; Barbiero et al., 2007, 2008; Martins, 2012).

No caso da Depressão Fechada há também entrada de água por fluxo subsuperficial, porém esta água é, em seguida, eliminada para fora do sistema, não ocorrendo concentração, mas evasão, de águas superficiais e subsuperficiais. 


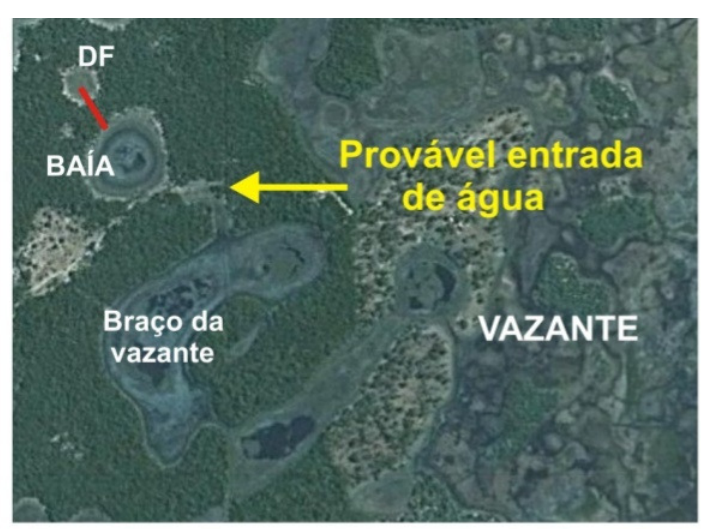

\section{Dia 14/03/1}

\section{Período de cheia}
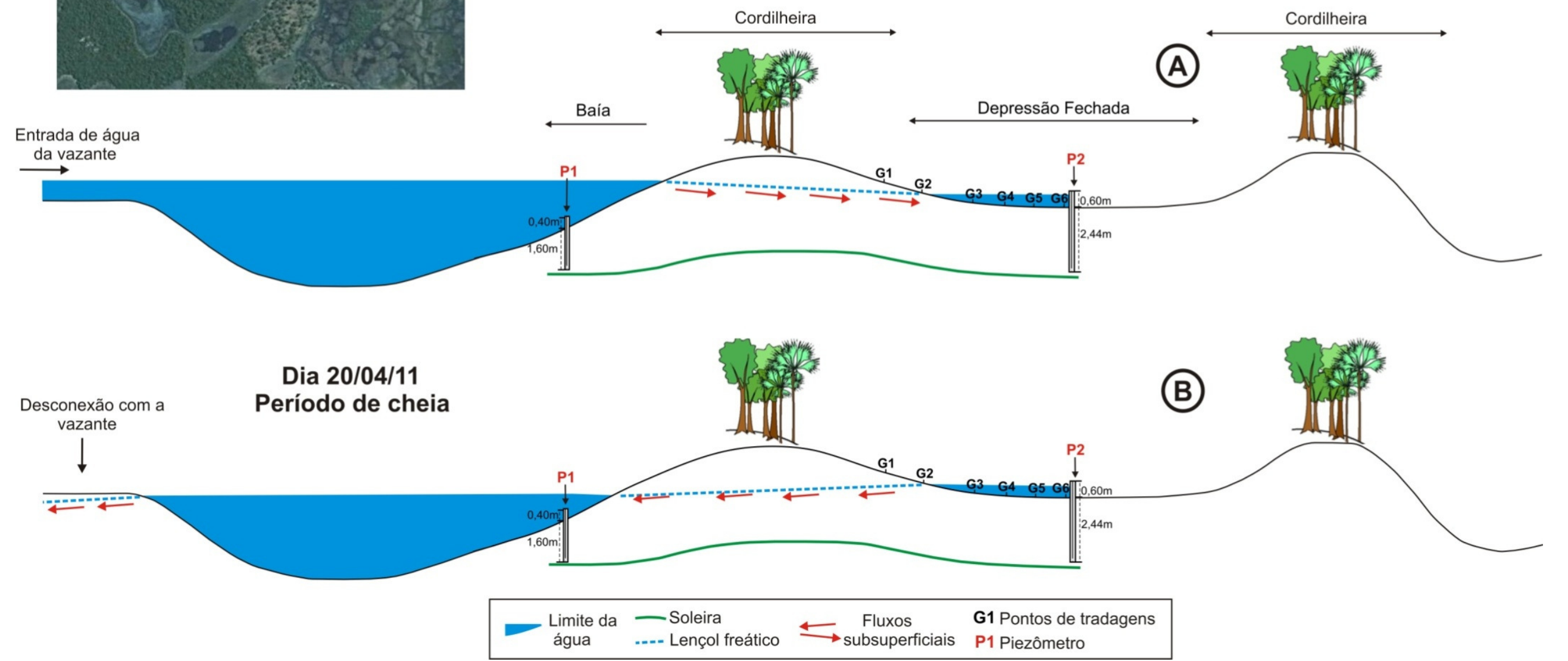

Figura 40 - (A) Primeira situação: invasão das águas superficiais da vazante na Baía, e fluxos das águas do lençol da Baía em direção à Depressão Fechada; (B) Segunda situação: desconexão com as águas superficiais da vazante e fluxos de águas subsuperficiais da Depressão Fechada em direção à Baía. 


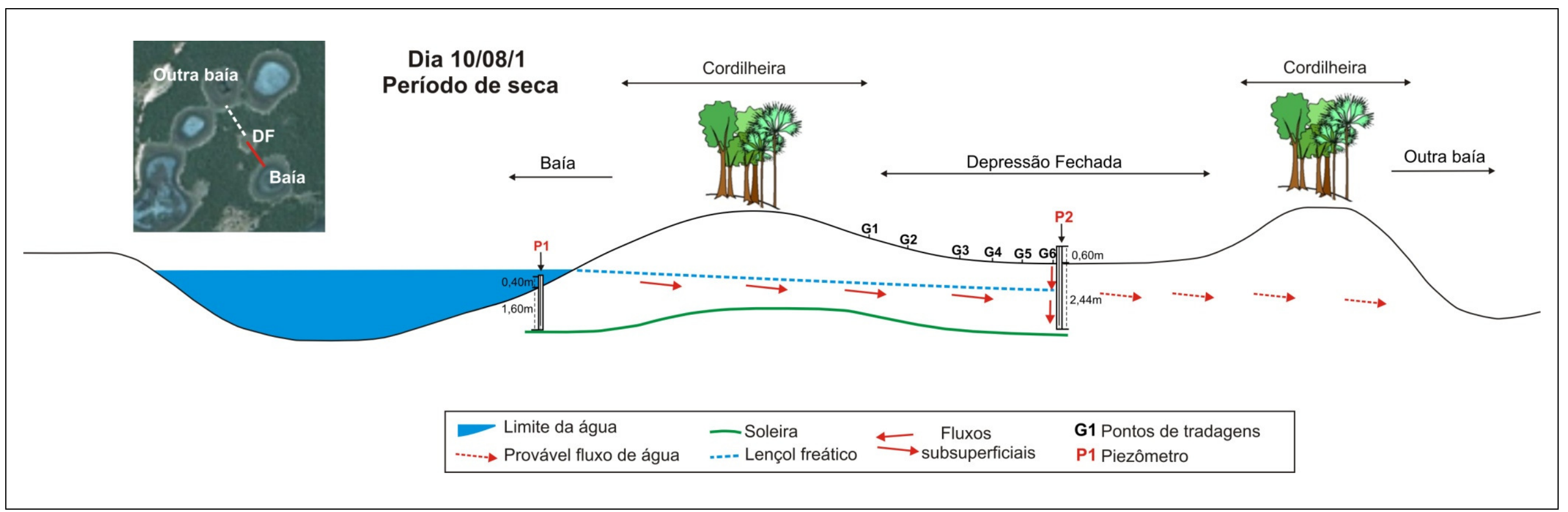

Figura 41 - Nível do lençol freático mais alto na Baía, fluxos subsuperficiais em direção à Depressão Fechada e fluxos de saída das águas da depressão. 


\section{B) Dinâmica das águas nas Depressões Abertas}

As Depressões Abertas apresentam uma dinâmica hídrica diferente da descrita na Depressão Fechada. Por estarem inseridas em um sistema aberto de drenagem recebem águas superficiais da vazante, e permanecem mais tempo com água em superficie.

Durante esta pesquisa foram realizados cinco campos em diferentes períodos, nas áreas de estudo, que possibilitaram algumas observações, e permitiram formular uma hipótese sobre a dinâmica hídrica nas Depressões Abertas nas estações seca e úmida.

Em setembro de 2009 houve uma seca excepcional no Pantanal, e a Depressões Abertas1 e 2, e a vazante, estavam secas. Destaca-se que este foi o único período em que a Depressão Aberta 1 ficou seca (Figura 42 A).

No mês de maio de 2010, término da estação chuvosa, as Depressões Abertas 1 e 2, e toda a área ao entorno estavam cobertas por água.

Em setembro de 2010, período de seca, a Depressão Aberta 1 ainda estava bem cheia de água, e a Aberta 2 seca (Figura 42 B). No ano seguinte, em julho de 2011, após estação úmida e início da seca, as duas Depressões Abertas permaneciam cobertas pelas águas, provavelmente em decorrência da cheia excepcional daquele ano (Figura 42 C). Em outubro de 2011 (Figura 42 D), início do período chuvoso, encontrou-se a Depressão Aberta 2 seca, e a 1 com bastante água.

Supõem-se que esses diferentes regimes hídricos, com períodos mais longos ou mais curtos de concentração de águas superficiais nas Depressões Abertas 1 e 2, estejam relacionadas ao grau de desenvolvimento do horizonte (6) verde argiloso, mais ou menos cimentado, que determina diferentes níveis freáticos a curtas distâncias, entre uma unidade morfológica e outra. No caso, das Depressões Abertas 1 e 2 essa distância é de, aproximadamente, 90 metros apenas. 


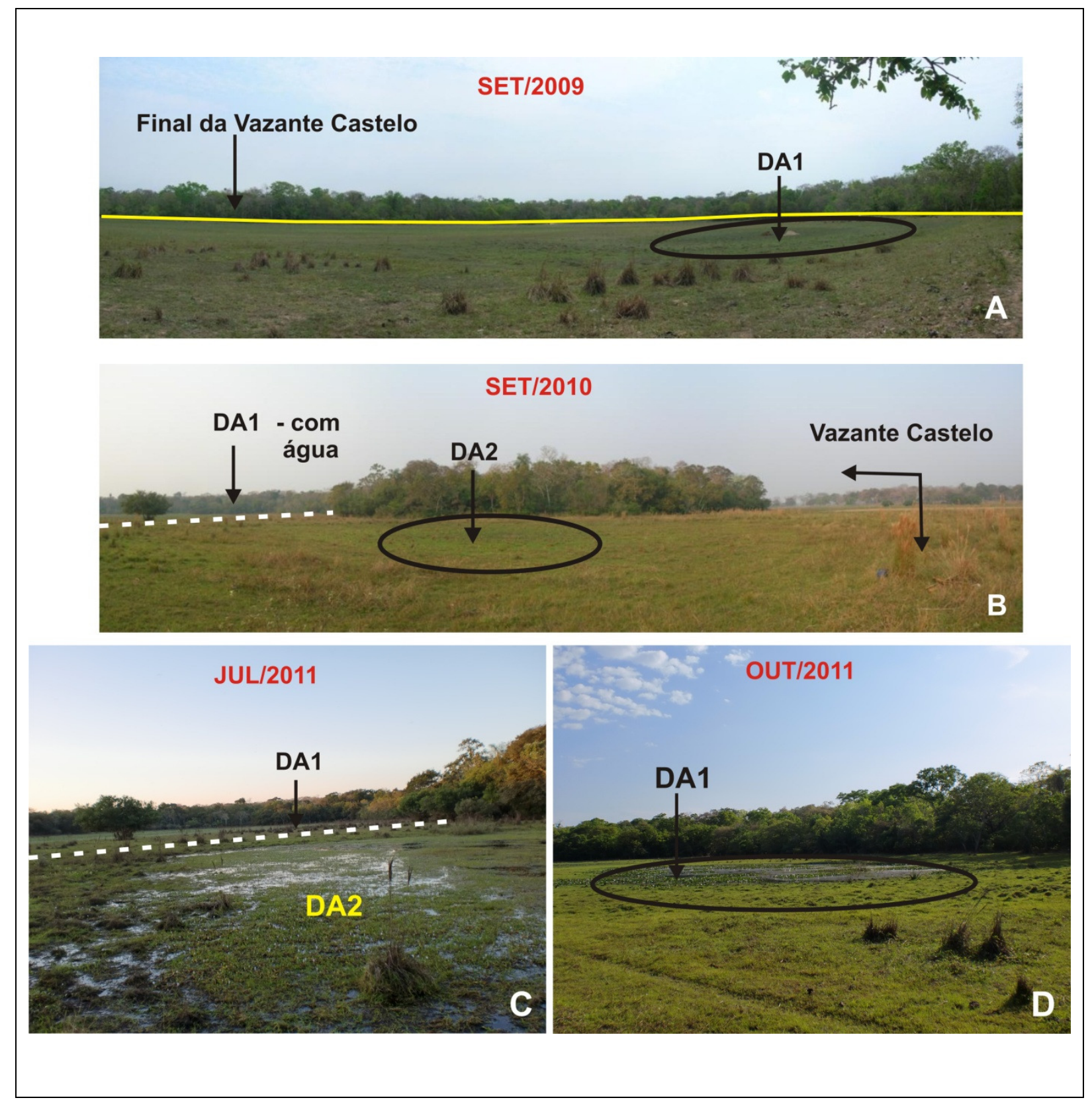

Figura 42 - Fotos que ilustram as Depressões Abertas secas e/ou cheias d’água nas respectivas datas de campo. 


\section{6- CONSIDERAÇÕES FINAIS}

Neste tópico salientam-se os seguintes pontos:

\section{A) Métodos}

O uso do método geofísico por indução eletromagnética se mostrou pertinente e eficiente para o estudo da distribuição espacial dos solos nas pequenas depressões, e permitiram atingir o primeiro objetivo específico deste trabalho.

Considerando-se que as áreas de estudo apresentam pequenos gradientes topográficos, o reconhecimento do terreno de forma indireta por indução eletromagnética, por meio de medidas da condutividade elétrica aparente (CEa) dos solos em diferentes profundidades, possibilitou um estudo morfológico mais rápido e eficaz. Diante dos testes realizados com os dados obtidos pelos aparelhos EM38 e EM31, os dados se mostraram confiáveis em relação às variações da CEa do terreno, ou seja, é possível identificar as diferenciações na cobertura pedológica. No entanto, seus valores absolutos não puderam ser considerados, pois há um problema de calibração automática interna do aparelho.

No futuro um esforço deverá ser feito para calibrar manualmente os aparelhos antes das medidas, sem considerar sua calibração automática.

\section{B) Mapa Fisiográfico}

A quantificação das unidades "pequenas depressões" mostra que esta unidade é significativa na área mapeada ao sul da Nhecolândia, e isto reforça sua importância na paisagem.

Esse mapeamento permitiu identificar uma direção preferencial NE-SW na distribuição conjunta das lagoas, pois individualmente são poucas, principalmente as de forma alongada, que apresentam direções preferenciais. A direção de um dos braços da Vazante Castelo coincide com a direção de paleofluxos do lobo 7, o mais antigo do leque aluvial do Taquari. Esta direção também foi reconhecida nas faixas dos maiores valores de CEa que cortam a Depressão Aberta 2. A hipótese levantada é que a Vazante Castelo está recortando, e retrabalhando (?), antigas estruturas sedimentares. 


\section{C) Morfologia dos solos}

As três pequenas depressões, apesar de se situarem em diferentes locais, dentro da Vazante Castelo e isolada dentro da cordilheira, compartilham um tipo de organização da cobertura pedológica, comum na Baixa Nhecolândia. Os horizontes descritos neste trabalho são similares aos identificados por outros autores, em outras unidades morfológicas dessa região. Todas as sequências estudadas apresentaram dois conjuntos de horizontes, divididos em função da textura, isto é: um conjunto arenoso formado pelos horizontes superficiais e subsuperficiais, e outro conjunto areno-argiloso, argilo-arenoso a argiloso, formado pelos horizontes profundos mais ou menos cimentados pela sílica amorfa. $\mathrm{O}$ contato abrupto entre esses dois grupos comandam os fluxos subsuperficiais, pois causam uma ruptura na permeabilidade.

$\mathrm{Na}$ base de todas as sequências de solos estudadas, encontrou-se o horizonte (6) verde argiloso, mais ou menos cimentado. No caso das pequenas depressões percebe-se que a forma desse horizonte apresenta elevações muito suaves, se comparadas com as das salinas. Nestas as elevações são mais pronunciadas, e o horizonte apresenta maior grau de cimentação. Isto indica que nas pequenas depressões, provavelmente este horizonte está em um menor grau de desenvolvimento. Apesar disto, pôde-se constatar sua influência no funcionamento hídrico da Depressão Fechada.

As diferenciações ocorrem, sobretudo, nos horizontes dos solos nas três pequenas depressões ligadas:

1) as redistribuições do ferro na paisagem, que caracterizam o horizonte (1c) amarelo arenoso no centro da Depressão Fechada e na elevação da sequência entre as Depressões Abertas 1 e 2, e na formação de plintitas no horizonte (7) argiloso da Depressão Aberta 2;

2) as redistribuições da matéria orgânica, que provavelmente ocorram concomitantemente a do ferro, com diferenciações de horizontes por perda de material, horizontes (2) e (3), e por adição de material, horizontes (3) e (4) na Depressão Aberta 1. Neste caso, em particular, a hipótese mais provável é de um processo de podzolização na sequência da Depressão Aberta 1.

Este estudo permitiu reconhecer os sistemas pedológicos que se desenvolvem nas pequenas depressões, assim como suas características morfológicas, granulométricas e mineralógicas. O estudo das características físico-químicas das águas nas pequenas depressões, acoplado ao estudo da morfologia do sistema pedológico, possibilitou 
identificar os processos de diferenciação de horizontes, comandados pelas redistribuições de ferro e matéria orgânica nas depressões. Estes aspectos mostram que os objetivos deste trabalho foram cumpridos.

\section{D) Funcionamento hídrico da Depressão Fechada}

A Depressão Fechada apresenta um funcionamento hídrico particular, pois constitui um local de evasão de águas e não de concentração, como as lagoas salinas. Em épocas de cheias excepcionais pode ocorrer uma concentração temporária e fugaz de águas superficiais no centro da depressão, que rapidamente sai do sistema.

O monitoramento piezométrico entre a Depressão Fechada e a Baía confirmou a importância, ao longo do tempo, dos fluxos subsuperficiais entre essas unidades morfológicas da paisagem. Além disto, também destacou que os fluxos de águas superficiais das vazantes para a Baía dependem da intensidade e frequência das chuvas, e ocorrem de maneira temporária por um período muito curto de tempo. No ano hidrológico estudado, o fluxo de água superficial da vazante para a Baía aconteceu no dia 05 de março de 2011, e foi interrompido 22 dias depois, no dia 27 de março, lembrandose que a estação chuvosa deste ano foi considerada excepcional. Isto confirma o papel dos fluxos subsuperficiais na Nhecolândia.

Finalmente, destaca-se que o método de aquisição automática de dados pelas sondas tipo Diver, instaladas nos piezômetros da Depressão Fechada e Baía, mostrou-se muito eficiente, pois possibilitou ter acesso a dados temporais não acessíveis em épocas de cheias, quando as estradas da região ficam inundadas e intrafegáveis.

\section{Perspectivas:}

O mapeamento fisiográfico aqui realizado em um pequeno recorte espacial deve ser ampliado a toda Nhecolândia. Sabe-se agora que a unidade "pequenas depressões" é representativa desta região, e a ampliação desse mapeamento permitiria identificar melhor suas relações funcionais com outras unidades morfológicas. Neste sentido, mais peso poderia ser dado ao monitoramento hídrico a fim de conhecer melhor a dinâmica da drenagem ao longo do tempo. O monitoramento realizado neste trabalho coincidiu com 
uma estação chuvosa excepcional, e seria interessante continuá-lo para verificar se as respostas dessa unidade se confirmam dentro de outro quadro pluviométrico.

Além disto, é necessário fazer um levantamento topográfico maior no entorno das pequenas depressões para entender a dinâmica hídrica superficial, principalmente nas Depressões Abertas 1 e 2, que recebem águas superficiais das vazantes.

A quantidade de pequenas depressões estudadas também precisa ser ampliada, para tentar verificar se a cobertura pedológica apresenta a mesma morfologia em função de suas localizações, seja dentro de cordilheiras, de vazantes ou como apêndices de lagoas.

Em todas as depressões estudadas neste trabalho, encontrou-se o horizonte verde argiloso, mais ou menos cimentado, na base das coberturas pedológicas. No entanto, este horizonte não é exatamente igual ao encontrado nas lagoas salinas, que parecem apresentar maior grau de desenvolvimento. Estes horizontes encontrados nas pequenas depressões representariam um estágio inicial ou final dos horizontes semelhantes descritos nas salinas? Para isto, são necessários estudos mais detalhados da organização pedológica do seu entorno, bem como análises mais detalhadas, ao longo do tempo, com caráter de monitoramento das águas circulantes. 


\section{7 - BIBLIOGRAFIA}

Ab'Saber, A.N. 2006. Brasil: paisagens de exceção: o litoral e o Pantanal MatoGrossense. Cotia - SP, Ateliê Editorial, 182 p.

Abu-Hassanein, Z.; Benson, C. \& Blotz, L.R. Electrical resistivity of compacted clays. Journal of Geotechnical Engineering. 1996; 122 (5): 397-406.

Adámoli, J. A dinâmica das inundações no Pantanal. In: Anais do 1ํ Simpósio sobre Recursos Naturais e Sócio-Econômicos do Pantanal; 27 de novembro a 4 de dezembro de 1984; Corumbá, MS; 1986. p. 51-61.

Agência Nacional de Águas (ANA). Endereço eletrônico: www.ana.gov.br. Acesso em 10/03/2011.

Almeida, F.F.M. \& Lima, M.A. Planalto Centro-Ocidental e Pantanal Matogrossense. Rio de Janeiro, IBGE. Guia de Excursão ํㅜ 1 do Congresso Internacional de Geografia; 1959. p. 171.

Almeida, F. F. M. Geologia do centro-oeste mato-grossense. Boletim da Divisão de Geologia e Mineralogia, Rio de Janeiro. 1964; v.215, p.1-133.

Amaral Filho, Z.P. Solos do Pantanal Matogrossense. In: Anais do 1ํ Simpósio sobre Recursos Naturais e Sócio-Econômicos do Pantanal; 27 de novembro a 4 de dezembro de 1984; Corumbá, MS; 1986. p. 91-103.

Alvarenga, S. M., Brasil, A. E., Del'Arco, D. M. Geomorfologia. In: Brasil. Ministério das Minas e Energia. Projeto RadamBrasil. Folha SF.21 Campo Grande, 1982. (Levantamento de Recursos Naturais, 28); 1982. p. 125-184.

Alvarenga, S. M.; Brasil, A. E.; Pinheiro, R.; Kux, H. J. H. Estudo geomorfológico na Bacia do Alto Rio Paraguai e Pantanais Mato-Grossenses. In: Brasil. Ministério das Minas e Energia. Secretaria Geral. Projeto RadamBrrasil. Boletim Técnico; 1984.

Assine, M. L. Sedimentação na Bacia do Pantanal Mato-Grossense, CentroOeste do Brasil [tese livre-docência]. Rio Claro: Universidade Estadual Paulista, Instituto de Geociências e Ciências Exatas; 2003.

Assine, M.L. Ambientes de leques aluviais. In: Ambientes de sedimentação siliciclástica do Brasil. 2008; p. 53-71. Orgs: Augusto José de C.L.; Pedreira da Silva; Maria Alice Nascimento Fagundes de Aragão; Antônio Jorge Campos Magalhães. São Paulo: Beca-BALL Edições. 
Bacani, V.M.; Sakamoto, A.Y.; Sakamoto, L.L.S.; Mascré, C.; Barbiero, L.; Queiroz Neto, J.P. Oscilação sazonal do lençol freático no entorno da lagoa Salina do Meio, Pantanal da Nhecolândia (MS). IV Simpósio sobre Recursos Naturais e Sócio-econômicos do Pantanal; 23 a 26 de novembro de 2004; Corumbá, Brasil. Corumbá: Simpam; 2004.

Becegato, V.A.; Ferreira, F.J.F. Gamaespectrometria, resistividade elétrica e susceptibilidade magnética de solos agrícolas no noroeste do estado do Paraná. Revista Brasileira de Geofísica. 2005; 23(4): 371-405.

Beirigo, R.M. Sistema pedológico Planossolo-Plintosso no Pantanal de Barão de Melgaço-MT [dissertação]. Piracicaba: Escola Superior de Agricultura Luiz de Queiroz, Agronomia; 2008.

Barbiéro, L.; Queiroz Neto, J.P.; Sakamoto, A.Y. Características geoquímicas dos solos relacionadas à organização pedológica e à circulação da água (Fazenda Nhumirim: Embrapa CPAP, Nhecolândia, MS). In: Anais do $3^{\circ}$ Simpósio sobre Recursos Naturais e Sócio-Econômicos do Pantanal, Corumbá, MS; 2000. p. 90-100.

Barbiero, L, Cunnac, S., Mané, L., Laperrousaz, C., Hammecker, C., Maeght, J. L. Salt distribution in the Senegal middle valley analysis of a saline structure on planned irrigation schemes from N'Galenka creek. Elsevier, Agricultural Water Management. 2001; 46: 201-213.

Barbiero, L.; Queiroz Neto, J. P.; Ciornei, G.; Sakamoto, A.; Capellari, B.; Fernandes, E.; Valles, V. Geochemistry of water and grounwater in the Nhecolândia, Pantanal of Mato Grosso, Brazil: variability and associated processes. Wetlands. 2002; 22(3): 528-540.

Barbiéro, L., Furquim, S. C., Valles, V., Furian, S., Sakamoto, A., Rezende Filho, A. T., Graham, R. C., Fort, M. Natural arsenic in Groundwater and alkaline lakes at the upper Paraguay basin, Pantanal, Brazil. In Battacharya P., Mukherjee A.B., Bundschuh J., Zevenhoven R., Loeppert R.H. (Ed.) Arsenic in Soil and Groundwater Environment: Biogeochemical interactions. Elsevier Book Series "Trace metals and other contaminants in the environment" (J.O. Nriagu, Serie Ed.), v 9, Chapter 4, 2007.101-126p.

Barbiero, L.; Rezende Filho, A. T.; Furquim, S. A. C.; Furian, S.; Sakamoto, A. Y.; Valles, V.; Graham, R. C.; Fort, M.; Fereira, R. P. D.; Queiroz Neto, J.P. Soil morphological control on saline and freshwater lake hydrogeochemistry in the Pantanal of Nhecolândia, Brazil. Geoderma. 2008; 148: 91-106. 
Barros, A M.; Silva, R. H.; Cardoso, O R. F. A; Freire, F. A; Júnior, J. J. S.; Rivetti, M.; Luz, D. S.; Palmeira, R. C. B.; Tassinari, C. C. G. Geologia. In: Projeto RadamBrasil. Folha SD. 21 Cuiabá. Rio de Janeiro. Levantamento de Recursos Naturais; 1982; v. 26, p. 25-192.

Bocquier, G. Génèse et evólution de deux toposéquences de sols tropicaux du Tchad, intérpretation biogéodynamique [tese]. Paris, Mém; Ciências ORSTOM; 1971. v. 62. p. 351.

Boulet, R. Existence de systèmes à forte différentiation laterale em milieu ferralitique guyanais: un nouvel exemple de couverture pédologique en déséquilibre. Science du Sol. 1978; 2: 75-82.

Boulet, R., Chauvel, A., Humbel, F.X., Lucas, Y. Analyse structurale et cartographie en pédologie. I - Les études de toposéquences et principaux apports à la connaissance des sols. II - Une méthode d'analyse prenant en compte l'analyse tridimensionnelle des couvertures pédologiques. III - Passage de la phase analytique à une cartographie générale synthétique. Cahier ORSTOM Séries Pédologie. 1982; 19: 309-351.

Boulet, R.; Fritsch, E.; Filizola, H.F.; Araújo Filho, J.C.; Leprun, J.C. \& Abrretto, F. Iron bands, fragipans and duripans in the northeastern plateaus of Brazil properties and genesis. Canadian J. Soil Sci. 1998; 78: 519-530.

Braun, E.W.G. Cone aluvial do Taquari, unidade geomórfica marcante da planície quaternária do Pantanal. Revista Brasileira Geografia. 1977; 39: 164180.

Bueno, G.T. Empobrecimento e podzolização de solos lateríticos da Bacia do rio Negro e gênese dos podzóis na Alta Bacia Amazônica [tese]. Rio Claro: Universidade Estadual Paulista, Instituto de Geociências e Ciências Exata; 2009.

Bullock, P.; Fedoroff, N.; Jongerius, A.; Stoops, G.; Tursina, T. Handbook for soil thin section description. Wolverhampton: Waine Research Publications, 1954. p. 152.

Capellari, B. Sensoriamento Remoto aplicado ao estudo da dinâmica hidrológica da região da Nhecolândia, Pantanal Matogrossense, MS [dissertação]. São Paulo: Universidade de São Paulo, Faculdade de Filosofia, Letras e Ciências Humanas; 2001.

Carvalho, N.O. Hidrologia da bacia do Alto Paraguai. In: Anais do $1^{\circ}$ Simpósio sobre Recursos Naturais e Sócio-Econômicos do Pantanal; 27 de novembro a 4 de dezembro de 1986; Corumbá, MS; 1986. p. 43-49. 
Castro, S.S. Micromorfologia de solos: bases para descrição de lâminas delgadas. UNICAMP/IG/DGEO, UFG/IESA. Campinas/Goiânia. 2008, 2ªed.

Costanza, R.; D’Arge, R.;Groot, R.de; Farber, S.; Grasso, M.; Hannon, B.; Limburg, K.; Naeem, S.; O'Neill, R.V.; Paruelo, J.; Raskin, R.G.; Sutton, P. \& Van Den Belt, M. The value of the world's ecosystem services and natural capital. Nature. 1997, 15 May; 387: 253-260.

Coutard, J.P.; Cohler, H.C.; Journaux, A. Carta do Carst - région de Pedro Leopoldo- Lagoa Santa, Minas Gerais, esc. 1:50.000. Univ. de Caen \& Centre de Géomorphologie CNRS, 1978. (acompanha texto).

Christofoletti, A. Geomorfologia fluvial. São Paulo: Edgard Blucher; 1981. 312 p.

Coringa, E.A.O.; Couto, E.G.; Perez, X.L.O.; Torrado, P.V. Atributos de solos hidromórficos no Pantanal Norte Matogrossense. Acta Amazonica. 2012; 42(1): 19-28.

Cunha, J. Cobre do Jauru e lagoas alcalinas no Pantanal (Mato Grosso). Boletim do Laboratório de Produção Mineral. 1943; 6: 1-43.

Cunha, N.G. Considerações sobre os solos da sub-região da Nhecolândia, Pantanal Mato-Grossense. Circular Técnica Embrapa. 1980; 1: 1-45.

Cunha, N.G. Classificação e Fertilidade de Solos da Planície Sedimentar do rio Taquari, Pantanal Matogrossense. Circular Técnica Embrapa. 1981; 4: 1-55.

Del'Arco, J.O.; Silva, R.H.; Tarapanoff, I.; Freire, F.A.; Pereira, L.G.M.; Souza, S.L.; Luz, D.S.; Palmeira, R.C.B.; Tassinari, C.C.G. Geologia. Folha SE.21Corumbá e parte da Folha SE.20. In: Projeto RadamBrasil - Levantamento dos Recursos Naturais. Rio de Janeiro; 1982. p. 25-160.

Domsch, $\mathrm{H}$,; Giebel, A. Estimation of soil textural features from soil electrical conductivity recorded using the EM38. Precision Agriculture. 2004; 5: 389-409.

Elis, V.R. A geofísica como ferramenta para detector e mapear contaminação. Material básico - principais métodos geofísicos e aplicações. Departamento de Geofísica - IAG/USP, 2005.

Elis, V.R. A Aplicação de Geofísica para Análise do Meio Físico: Importância para elaboração de Mapeameto Geotécnico [dissertação]. Rio Claro: Universidade Estadual Paulista, Instituto de Geociências e Ciências Exatas; 1993. 
Embrapa. Manual de métodos de análise de solo. Centro Nacional de Pesquisa de Solos. 2.ed. rev. atual. Rio de Janeiro, 1997. 212 p.

Embrapa. Sistema Brasileiro de Classificação de Solos. $2^{\underline{a}}$ edição, Embrapa Solos, Rio de Janeiro, 2006. 306p.

Fernandes, E. Organização espacial dos componentes da paisagem da Baixa Nhecolândia - Pantanal de Mato Grosso do Sul [tese]. São Paulo: Universidade de São Paulo, Faculdade de Filosofia, Letras e Ciências Humanas; 2007.

Fernandes, E. Análise espacial dos meios ácidos e alcalinos e suas relações com a estrutura e organização dos elementos da paisagem regional da Baixa Nhecolândia - Pantanal de Mato Grosso do Sul [tese relatório de qualificação]. Universidade de São Paulo: Faculdade de Filosofia, Letras e Ciências Humanas; 2005. 138 p.

Fernandes, E. Caracterização dos Elementos do Meio Físico e da Dinâmica da Nhecolândia (Pantanal Sulmatogrossense) [dissertação]. São Paulo: Universidade de São Paulo, Faculdade de Filosofia, Letras e Ciências Humanas; Departamento de Geografia; 2000.

Fitz, P. R. Geoprocessamento sem complicação. São Paulo: Oficina de Textos, 2008. $160 \mathrm{p}$.

Formoso, M.L.L. Difratometria de raios X. In: Gomes, C.B. (Ed) Técnicas analíticas instrumentais. Ed. Edgard Blücher Ltda. p. 1-43.

Fraisse, C.W.; Sudduth, K.A.; Kitchen, N.R. Delineation of site-specific management zones by unsupervised classification of topographic attributes and soil electrical conductivity. American Society of Agricultural Engineers. 2001; 44(1): 155-166.

Franco, M.S.M. \& Pinheiro, R. Geomorfologia. Folha SE.21 Corumbá e parte da Folha SE.20. In: Projeto RadamBrasil - Levantamento dos Recursos Naturais. Rio de Janeiro; 1982. p.161-224.

França, A. M. da S., Patrícia, G., Sano, E. E. Gênese e morfologia dos sistemas lacustres da planície aluvial do Rio Araguaia. Anais. In: IX Simpósio Nacional Cerrado e II Simpósio Internacional Savanas Tropicais. Brasília, 2008. p.1-7.

Fukue, M.; Minato, T.; Horibe, H.; Taya, N. The micro-structures of clay given by resistivity measurements. Engineering Geology. 1999; 54: 43-53. 
Furquim, S.A.C., Graham, R.C., Queiroz Neto, J.P., Furian, S., Barbiero, L., Feillite neoformation in an alkaline environment, Pantanal wetland, Brazil. Proceeding of the Soil Science Society of America Annual Meeting. CD media, Seattle; 2004.

Furquim, S.A.C. Formação de carbonatos e argilo-minerais em solos sódicos do Pantanal Sul-Mato-Grossense [tese]. São Paulo: Universidade de São Paulo, Faculdade de Filosofia, Letras e Ciências Humanas; Departamento de Geografia; 2007.

Furquim, S. A. C.; Graham, R.; Barbiero, L.; Queiroz Neto, J. P. de; Valles, V. Mineralogy and genesis of smectites in an alkaline-saline environment of Pantanal wetland, Brazil. Clays and Clay Minerals. 2008; 56: 580-596.

Furquim, S.A.C.; Graham, R.C.; Barbiero, L.; Queiroz Neto, J.P.; Vidal-Torrado, $P$. Soil mineral genesis and distribution in a saline lake landscape of the Pantanal Wetland, Brazil. Elsevier, Geoderma. 2010; 154: 518-528.

Galdino, S.; Padovani, C.R.; Soriano, B.M.A.;Vieira, L.M. Mudanças no regime hidrológico da bacia hidrográfica do Rio Taquari - Pantanal. Corumbá: Embrapa Pantanal, 2002. 24p. (Embrapa Pantanal. Boletim de Pesquisa, 26).

Gascuel-Odoux, C., Boivin P. Variability of variograms and spatial estimates due to soil sampling: a case study. Geoderma. 1994 ; 62: 165-182.

Geonics Limited. EM38 ground conductivity meter operating manual. Geonics Ltd, Mississauga, Ontário, Canadá; 2008.

Godoi Filho, J.D. Aspectos geológicos do Pantanal Mato-Grossense e de sua área de influência. In: Anais do $1^{\circ}$ Simpósio sobre Recursos Naturais e SócioEconômicos do Pantanal, 27 de novembro a 4 de dezembro de 1984; Corumbá, MS; 1986. p. 63-76.

Gonçalves, A.C.A. Variabilidade espacial de propriedades físicas do solo para fins de manejo de irrigação [tese]. Piracicaba: Escola Superior de Agricultura "Luiz de Queiroz"; 1997.

Hamilton, S.K. Potential effects of a major navigation project (Paraguay-Parana hidrovia) on inundation in the Pantanal floodplains. Regulated Rivers: Research \& Management. 1999; 15: 289-299.

Hamilton, S.K.; Sippel, S.J.; Melack, J.M. Inundation patterns in the Pantanal wetland of South America determined from passive microwave remote sensing. Arch. Hydrobiol. 1996; 37: 1-23. 
Hamilton, S.K., Sippel, S.J. \& Melack, J. Comparison of inundation patterns among major South American floodplains. J. Geophys. Res. 2002; 107: 1-14.

IBGE. Instituto Brasileiro de Geografia e Estatística. Mapa de solos do Brasil. 2001.

Kitchen, N.R.; Sudduth, K.A.; Myers, D.B.; Drummond, S.T.; Hong, S.Y. Delineating productivity zones on claypan soil fields using apparent soil electrical conductivity. Computers and Electronics in Agriculture. 2005; 46: $285-$ 308.

Krumbein, W.C. Measurement and geological significance of shape and roundness of sedimentary particles. Journal of Sedimentary Research. 1941, Aug; 11(2): 64-72.

LABSED. Manual de procedimentos analíticos. Instituto de Geociências da USP - Laboratório de Sedimentologia, São Paulo, 2004.

Landim, P.M.B. Análise estatística de dados geológicos. São Paulo: Fundação Editora da UNESP, 1998.

Laureano, A. T. Estudos geofísicos no aterro sanitário de Cuiabá, MT [dissertação]. Universidade Federal de Mato Grosso, Instituto de Ciências Exatas e da Terra; 2007.

Loureiro, R.L.; Lima, J.P.S.; Fonzar, B.C.; Oliveira Filho, L.C. Vegetação: as regiões fitoecológicas, sua natureza e seus recursos econômicos. Folha SE.21 Corumbá e parte da Folha SE.20. In: Projeto RadamBrasil - Levantamento dos Recursos Naturais. Rio de Janeiro; 1982. p. 329-372.

Lundström, U.S., van Breemen, N., Bain, D. The Podzolisation process. A review. Geoderma. 2000; 94: 91-107.

Macedo, E.L. da R. Pedologia: levantamento exploratório de solos. Folha SF.21 - Campo Grande. In: Projeto RadamBrasil - Levantamento dos Recursos Naturais. Rio de Janeiro; 1982. p. 185-280.

Martins, E.R.C.; Furian, S.M.; Rezende Filho, A.T. Distribuição espacial da salinidade em lagoas da Nhecolândia, Pantanal (MS). Revista GeoPantanal. 2011, jan/jun; 6(10): 87-100.

Martins, E. R. C. Tipologia de lagoas salinas no Pantanal da Nhecolândia (MS) [tese]. São Paulo: Universidade de São Paulo, Faculdade de Filosofia, Letras e Ciências Humanas, 2012. 
McNeill, J. D. Electromagnetic terrain conductivity measurement at low induction numbers. Tech.Note TN-6, Geonics Limited, Ontário, Canadá. 1980.

Melack, J. M. Amazon Floodplain lakes: shape, fetch and stratification. Verh. Internacional Verein limnology, Stuttgart. 1984; 22: 1278-1282.

Mendonça, F.; Danni-Oliveira, I.M. Climatologia: noções básicas e climas do Brasil. São Paulo: Oficina de Textos; 2007. 206 p.

Molin, J.P.; Castro, C.N. Aliada potencial. Cultivar. 2006, mar; II(6): 8-11.

Morrison, R.I.G.; Manore, M.; Ross, R.K.; Padovani, C.R. Identificação das lagoas salinas da região da Nhecolândia - Pantanal, através de técnicas de sensoriamento remoto. III Simpósio sobre Recursos Naturais e Sócioeconômicos do Pantanal, Corumbá-MS, (Resumo); 2000. p. 88-89.

Moura, P. Bacia do Alto Paraguai. Revista Brasileira de Geografia. 1943, jan/mar; V(1): 3-38.

Mourão, G.M. Limnologia comparativa de três lagoas (duas baías e uma salina) do Pantanal da Nhecolândia, MS [dissertação]. São Carlos: Universidade Federal de São Carlos, Departamento de Ciências Biológicas; 1989.

Mousinho de Meis, M. R. \& Tundisi, J. G. Geomorphology and limnological processes as a basis for lake typology: the middle Rio Doce Valley Lake System. Anais da Academia Brasileira de Ciências. 1986; 58: 103 - 120.

Nascimento, C.T.C.; Pires, A.C.B.; Moraes, R.A.V. Reconhecimento de solos por meio de resistividade el'etrica e radiação gama. Revista Brasileira de Geociências. 2004; 34(3): 383-392.

Nascimento, N. R.; Michelon, C.; Bueno, G. T; Dias, R.P.; Aquino, A.; Beato, D.; Diniz, A.D. Dinâmicas da matéria orgânica e do lençol freático suspenso: evolução geomorfológica de uma paisagem podzolizada - Espinhaço Meridional - MG. Brasil. In: VI Seminário Latino-Americano de Geografia Física. Universidade de Coimbra, Maio de 2010.

Oliveira, C. de. Caracterização geofísica do solo para uso em agricultura de precisão [dissertação]. São Paulo: Universidade de São Paulo, Instituto de Astronomia, Geofísica e Ciências Atmosféricas; 2006.

Oliveira, C. M. B.; Moya, G. E.; Mello, R. P. Flutuação populacional de Cochliomyia hominivorax no município de Itaguaí, Rio de Janeiro. Pesquisa Veterinária Brasileira. 1982; 2(4): 139-142. 
Orioli, A.L.; Amaral Filho, Z.P.; Oliveira, A.B. Pedologia: levantamento exploratório de solos. Folha SE.21 Corumbá e parte da Folha SE.20. In: Projeto RadamBrasil - Levantamento dos Recursos Naturais. Rio de Janeiro; 1982. p. 225-328.

Parizotto, T.M.; Furian, S.M.; Barbiero, L. Estudo da cobertura pedológica de uma micro-depressão por indução eletromagnética - Pantanal da Nhecolândia, MS. Revista GeoPantanal. 2011, jan/jun; 6(10): 75-86.

PCBAP. Plano de conservação da Bacia do Alto Paraguai - PCBAP/Projeto Pantanal, Programa Nacional do Meio Ambiente. Brasília: PNMA, 1997. 3 vol. em 7 t., il., fig., mapas.

Pereira, J.V.C. Pantanal. Revista Brasileira de Geografia. 1944, abr/jun; IV(2): 281-284.

Pessoa, A. L. Uma abordagem Bayesiana para estudo estatístico e geoestatístico de estimativas de salinidade do solo utilizando sensor de indução eletromagnética [dissertação]. Recife: Universidade Federal Rural de Pernambuco, Biometria; 2006.

Por, F.D. The Pantanal of Mato Grosso (Brazil) - World's Largest Wetlands. Klumer Academic Publishers. 1995; 122 p.

RadamBrasil, Ministério das Minas e Energias. Secretaria Geral. Folha SE. 21 Corumbá e parte da Folha SE. 20. Geologia, Geomorfologia, Pedologia, Vegetação e Uso potencial da terra. vol. 27, Rio de Janeiro; 1982.

Rezende Filho, A. T. Estudo da variabilidade e espacialização das unidades da paisagem: Banhado (baía/vazante), Lagoa Salina e Lagoa Salitrada no Pantanal da Nhecolândia, MS [dissertação]. Aquidauana: Universidade Federal do Mato Grosso do Sul; 2006.

Rezende Filho, A. T. Variabilidade química das águas na Bacia do Alto Paraguai: uma compartimentação do Pantanal Mato-grossense [tese]. São Paulo: Universidade de São Paulo, Faculdade de Filosofia, Letras e Ciências Humanas; Departamento de Geografia; 2011.

Rongjiang Y., Jingsong Y. Quantitative evaluation of soil salinity and its spatial distribution using electromagnetic induction method. Agricultural Water Management. 2010, Nov; 97(12): 1961-1970. 
Sakamoto, A. Y. Dinâmica hídrica em uma lagoa salina e seu entorno no Pantanal da Nhecolândia: contribuição ao estudo das relações entre o meio físico e a ocupação, Fazenda São Miguel do Firme, MS [tese]. São Paulo: Universidade de São Paulo, Faculdade de Filosofia, Letras e Ciências Humanas; Departamento de Geografia; 1997.

Shiraiwa, S. Flexura da litosfera continental sob os Andes Centrais e a origem da bacia do Pantanal [tese]. São Paulo: Universidade de São Paulo, Instituto Astronômico e Geofísico; 1994.

Siedl, A.F.; Moraes, A.S. Global valuation of ecosystem services: application to the Pantanal da Nhecolândia, Brazil. Ecological Economics. 2000; 33: 1-6.

Silva, J.S.V.; Abdon, M.M. Delimitação do Pantanal Brasileiro e suas subregiões. Pesquisa Agropecuária Brasileira. 1998, Out; 33(especial): 1703-1711.

Silva, T.C. Contribuição da geomorfologia para o conhecimento e valorização do Pantanal. In: Anais do $1^{\circ}$ Simpósio sobre Recursos Naturais e SócioEconômicos do Pantanal, 27 de novembro a 4 de dezembro de 1984; Corumbá, MS; 1986. p. 77-90.

Sudduth, K.A.; Drummond, S.T.; Kitchen, N.R. Accuracy issues in electromagnetic induction sensing of soil electrical conductivity for precision agriculture. Computers and Electronics in Agriculture. 2001; 31: 239-264.

Tarifa, J.R. O sistema climático do Pantanal: da compreensão do sistema à definição de prioridades de pesquisa climatológica. In: Anais do $1^{\circ}$ Simpósio sobre Recursos Naturais e Sócio-Econômicos do Pantanal, 27 de novembro a 4 de dezembro de 1984; Corumbá, MS; 1986. p. 9-27.

Uagoda, R.; Avelar, A. de S.; Coelho Netto, A.L. Depressões Fechadas em relevo cárstico-quatzítico, bacia do Ribeirão Santana, médio vale do rio Paraíba do Sul. Anuário do Instituto de Geociências. 2006; 29(2): 87-100.

Viana, J. A. P; Sakamoto, A. Y.; Oliveira, W de. Estudo do monitoramento do nível do lençol freático da lagoa Salina do Meio, Fazenda Nhumirim, Pantanal da Nhecolândia, MS. In: Anais Encontro Nacional de Geógrafos. Rio Branco, AC; 2006.

Zani, H. Mudanças morfológicas na evolução do megaleque do Taquari: uma análise com base em dados orbitais [dissertação]. Rio Claro: Universidade Estadual Paulista, Departamento de Geociências e Meio Ambiente; 2008. 


\section{ANEXO 1}

Descrições das características morfológicas da trincheira e das sequências de solos estudadas 


\section{DEPRESSÃO ABERTA 1}

P1 (borda da depressão, ao lado da cordilheira)

0 - $10 \mathrm{~cm}$ : arenoso bem fino, de cor clara, mas com alguma matéria orgânica (em relação aos outros é mais escuro).

$10-20 \mathrm{~cm}$ : fica ligeiramente mais úmido.

$20-35 \mathrm{~cm}$ : arenoso, areia muito fina e mescla cor, homogênea.

$35-48 \mathrm{~cm}$ : matriz ligeiramente mais clara, areia ligeiramente mais grossa.

$48-66 \mathrm{~cm}$ : aparece com algumas manchas (poucas) mais escuras.

66 - $70 \mathrm{~cm}$ : aparecem mais manchas de matéria orgânica e linhas avermelhadas.

$70-130 \mathrm{~cm}$ : volta uma areia bem fina, sem manchas e cor bem clara e um pouco úmida.

$130 \mathrm{~cm}$ : aparece na ponta do trado manchas/linhas escuras de matéria orgânica e algumas manchas pouco contrastadas de ferro.

$130-150 \mathrm{~cm}$ : mudou a cor da matriz, mais escuro, parece ligeiramente mais argiloso, cor escura não homogênea, com manchas claras. Bem mais úmido, vai umedecendo à medida que se aprofunda.

$150 \mathrm{~cm}$ : na ponta do trado ficou bem mais escuro, com mais matéria orgânica e ligeiramente mais argiloso, mais úmido e cor cinza escuro.

$155 \mathrm{~cm}$ : água livre, com tons de cinza mais claro e um pouco mais escuro.

$160 \mathrm{~cm}$ : topo da camada verde, com um pouco de matéria orgânica em cima dela.

$160-220 \mathrm{~cm}$ : camada verde.

\section{P2}

$0-20 \mathrm{~cm}$ : areia muito fina de cor mais acinzentada, próximo ao primeiro horizonte da trincheira.

$20-75 \mathrm{~cm}$ : areia clara, friável, correspondente à segunda camada da trincheira.

75 - $80 \mathrm{~cm}$ : começa a surgir manchas mais escuras, matriz mais úmida e a areia ligeiramente mais grosseira.

80 - 95cm: mais úmido, cor mais escura com matéria orgânica.

$95 \mathrm{~cm}$ : ponta do trado mais escuro.

$95-110 \mathrm{~cm}$ : aparecem manchas mais escuras, está mais nítida. Matriz e manchas bem contrastadas.

110 - $120 \mathrm{~cm}$ : o escuro esta ficando homogêneo e mais úmido.

$120 \mathrm{~cm}$ : água livre, mais escuro, cor bem homogêneo, marrom escuro.

130 - $140 \mathrm{~cm}$ : cor homogênea marrom escuro, mas sem água livre.

140 - $150 \mathrm{~cm}$ : na ponta do trado passagem abrupta para matriz cinza claro, bastante úmido com sinais de hidromorfia (linhas amarelas).

150 - $170 \mathrm{~cm}$ : passa para o cinza claro, sem hidromorfia.

$170 \mathrm{~cm}$ : começa a camada verde.

P3

0 - $30 \mathrm{~cm}$ : areia muito fina, mais escura, próximo a primeira camada da trincheira e P2.

$30-40 \mathrm{~cm}$ : inicio da areia fina mais clara.

$40-70 \mathrm{~cm}$ : começam as manchas mais escuras (linhas verticais de matéria orgânica) e fica mais úmido.

70 - $80 \mathrm{~cm}$ : na ponta do trado início de manchas marrom na matriz cinza claro.

80 - $100 \mathrm{~cm}$ : início da camada orgânica marrom escuro, bastante úmido.

$100-140 \mathrm{~cm}$ : inicia matriz cinza com sinal de hidromorfia, mesmo nível da trincheira (cores avermelhadas)

$140 \mathrm{~cm}$ : água livre com bastante manchas avermelhadas individualizadas e também pontos de matéria orgânica (marrom escuro).

145 - $150 \mathrm{~cm}$ : na ponta do trado, bastante manchas avermelhadas com pontos esverdeados entremeados por manchas escuras (preta).

$150-155 \mathrm{~cm}$ : camada verde.

P4

$0-30 \mathrm{~cm}$ : areia muito fina. 
$30-60 \mathrm{~cm}$ : na ponta do trado início da areia clara, pouco úmido.

$60-65 \mathrm{~cm}$ : ponta do trado marrom escuro, mudança abrupta com espessura de $5 \mathrm{~cm}$.

$65-120 \mathrm{~cm}$ : aparece manchas avermelhadas e escuras e alguns pontos de areia lavada entremeados com a matriz arenosa cinza claro, e sinais de hidromorfia.

$120 \mathrm{~cm}$ : água livre.

120 - $150 \mathrm{~cm}$ : início da camada verde com volumes ocres, pouca cerosidade.

150 - $180 \mathrm{~cm}$ : camada verde.

P5

$0-20 \mathrm{~cm}$ : areia seca meio cinza (quase homogêneo)

$20-60 \mathrm{~cm}$ : areia clara muito fina com pequenas manchas avermelhadas, e na base alguns pontos escuros.

60 - $90 \mathrm{~cm}$ : na ponta do trado mudança abrupta para o marrom escuro com manchas avermelhadas (bastante).

$100 \mathrm{~cm}$ : as manchas avermelhadas passam a dominar a matriz cinza.

$110 \mathrm{~cm}$ : volta ao cinza claro com manchas escuras e avermelhadas.

$120-160 \mathrm{~cm}$ : volumes escuros secos levemente endurecidos são pequenos nódulos na matriz cinza.

160 - $170 \mathrm{~cm}$ : muita umidade e volumes avermelhados menores e a camada cinza mais argilosa e mais clara.

$170 \mathrm{~cm}$ : água livre.

$170-190 \mathrm{~cm}$ : volta a aumentar os volumes avermelhados, bastante úmido.

$190-240 \mathrm{~cm}$ : diminui um pouco as manchas.

$240-250 \mathrm{~cm}$ : do cinza claro vai para o cinza mais escuro, bem homogêneo.

$250-270 \mathrm{~cm}$ : volta as manchas avermelhadas (pouco) entremeado com manchas verdes, na matriz cinza mais escuro.

$270 \mathrm{~cm}$ : início da camada verde com manchas avermelhadas, bastante úmido.

\section{$\operatorname{Tr}$ (Trincheira)}

(1) $0-12 \mathrm{~cm}$

Areia muito fina, com textura entre arenosa muito fina e siltosa. Horizonte orgânico com manchas avermelhadas e pretas dentro da matriz. Essas manchas avermelhadas aparecem em volta da porosidade, o que indica hidromorfia atual. Estrutura subhorizontal, sublinhada por presença de raízes, agregados em bloco subangular. Sua porosidade é tubular fina com máximo de $1 \mathrm{~mm}$ e mínimo de um décimo de $\mathrm{mm}$. A transição de um horizonte a outro é relativamente abrupta, porém ondulada. Cor: 10YR 6/1

\section{(2) $12-23 \mathrm{~cm}$}

Textura arenosa. Possui estrutura maciça com tendência horizontal, tem bandas onduladas nítidas com cores escuras no mesmo tom do horizonte anterior, porém descontínuas. Nessas bandas tem porosidade tubular mais marcada com um pouco de ferrugem. Tem limite ondulado. Cor: matriz seca $=10 \mathrm{YR} 6 / 1$; matriz úmida $=10 \mathrm{YR} 6 / 2$, manchas claras $=$ 10 YR 4/2, pontos escuros = 10 YR 3/1.

\section{(3) $23-52 \mathrm{~cm}$}

Textura arenosa. Porosidade intersticial (por ser areia) tubular induzido pelas raízes. Estrutura maciça. Tem atividade biológica (encontrado minhoca muito fina). No decorrer do horizonte vai ficando mais branco, gradualmente. Limite abrupto com forte contraste de cor. Cor: matriz seca $=10 \mathrm{YR}$ 7,8/2, matriz úmida $=10 \mathrm{YR}$ 5/3.

\section{(4) $52-75 \mathrm{~cm}$}

Textura arenosa, porém mais endurecido com bastante matéria orgânica (não se sabe a origem). Tem estrutura maciça, com material bem endurecido, não é areia solta. Possui várias manchas: escuras (matéria orgânica), areia lavada e coloração pelo ferro.

Dentro dessa matriz aparecem vários nódulos, com camada argilosa em volta do nódulo que externamente apresenta cor ferrugem e dentro a cor é marrom claro endurecido, que as 
vezes esta saturado de água. Tem nódulos de matéria orgânica também. Esses nódulos são pluricentimétricos com exterior ferrugem e auréola marrom claro e dentro material preto metálico. Os nódulos vão de 50 a $65 \mathrm{~mm}$. Na porosidade há manchas pretas em volta, são poros tubulares acompanhados pela matéria orgânica.

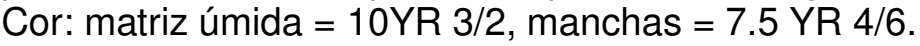

\section{(5) $75-125 \mathrm{~cm}$}

Textura arenosa. Estrutura maciça. Cor cinza. Porosidade intersticial e tubular mais finos e maiores, preenchidos com material branco (areia clara) e delimitados por linha avermelhada em volta, mas a maior parte dos tubos apresentam cor preta. Dentro da matriz há manchas avermelhadas (pequenas) e algumas acompanham a porosidade tubular atual.

No decorrer do horizonte, vai mudando a cor da matriz progressivamente, ficando mais clara com textura mais siltosa e um pouco de argila, porém ainda é arenosa.

Próximo à base do horizonte há transição de textura, cor e estrutura. Tem estrutura poliédrica angulosa com tamanho dos agregados de aproximadamente $2 \mathrm{~cm}$. Neste material aparecem bolsões de areia com $5 \mathrm{~cm}$ acompanhados por uma linha de ferro.

Tem algumas raízes. Porosidade tubular, e presença de hidromorfia. Limite bastante irregular, principalmente pelo contraste e aparecimento de volumes esverdeados.

Cor: matriz $=10$ YR 5/2, manchas avermelhadas $=5$ YR 4/6, manchas escuras $=7.5$ YR 3/1

\section{(6) $125-185 \mathrm{~cm}$}

Este horizonte tem uma matriz cinza com textura areno-argilosa, pegajoso, estrutura maciça. $\mathrm{Na}$ matriz, há volumes mais endurecidos avermelhados. O volume endurecido tem o centro avermelhado e o entorno branco e verde claro. Em geral, o branco aparece, sobretudo ao exterior e o verde claro no interior (mais próximos aos volumes endurecidos). Localmente, a 1,60 há água livre. Cor: matriz cinza $=5 Y$ 5/1, manchas cinzas claras $=2.5$ Y 6/2, verde mais claro = entre Gley $15 / 5 G$ e $5 Y$ 4/2, verde mais escuro (interior dos nódulos) = Gley 1 4/5G, verde $=$ entre Gley $14 / 5 \mathrm{G}$ a $3 / 5 \mathrm{G}$

Obs: volumes endurecidos são espalhados mais apresenta certa verticalidade.

\section{DEPRESSÃO ABERTA 2}

\section{T 1 (Centro)}

0 - $30 \mathrm{~cm}$ : arenoso, úmido, bastante matéria orgânica, matriz marrom.

$30-55 \mathrm{~cm}$ : arenoso, cor bege.

55 - 86 - muda a cor para cinza, volumes mais endurecidos (parece nódulos de ferro).

86 - ponta do trado volta a ficar cinza mais claro bastante úmido.

$90-120 \mathrm{~cm}$ : matriz cinza, com nódulos mais endurecidos vermelho ferrugem mais para o amarelo e escuros também.

$120 \mathrm{~cm}$ : água livre.

120 - $140 \mathrm{~cm}$ : matriz cinza mais amarelado com volumes de ferro cor avermelhado e escuro. Água livre em pequenos bolsões (entre volumes e matriz cinza).

140 - $180 \mathrm{~cm}$ : cinza, textura argilosa, matriz mais homogênea, diminui nódulos preto amarelados e aparecem mais nódulos ferruginosos. Sensação de mais arenoso que argiloso $180-200 \mathrm{~cm}$ : água livre - matriz cinza com volumes amarelados (areno-argiloso).

$200-220 \mathrm{~cm}$ : aparecem manchas cinzas e esverdeadas mais escuras.

$280 \mathrm{~cm}$ : a camada verde argilosa clara, está mais seca na matriz.

T2

0 - $30 \mathrm{~cm}$ : matriz marrom, arenosa e úmida.

$30-40 \mathrm{~cm}$ : areia branca com manchas escuras.

$40-80 \mathrm{~cm}$ : areia branca com manchas ocres.

80 - $140 \mathrm{~cm}$ : matriz cinza arenosa com acumulação de matéria orgânica e poucas manchas avermelhadas difusas.

140 - $190 \mathrm{~cm}$ : ponta do trado - matriz um pouco mais argilosa cor cinza com mais volumes avermelhados e mais secos. 
190 - $210 \mathrm{~cm}$ : matriz mais argilosa, cor variegada, com muito volumes avermelhados pedaços endurecidos.

$210 \mathrm{~cm}$ : aparecem volumes esverdeados.

$220 \mathrm{~cm}$ : matriz cinza com volumes verdes (camada verde).

T3

0 - $35 \mathrm{~cm}$ : orgânico, marrom escuro, arenoso.

$35-60 \mathrm{~cm}$ : troca a cor, fica bege claro, passagem gradativa, textura arenosa e diminui a matéria orgânica.

60 - 70 cm: volta matriz orgânica (marrom escuro), volumes de matéria orgânica arenoargilosa.

70 - $80 \mathrm{~cm}$ : transição da cor mais homogênea diminui volumes argilosos, fica mais arenoso e na ponta do trado aparecem volumes avermelhados.

80 - $100 \mathrm{~cm}$ : arenoso, manchas e volumes avermelhados difusos, na matriz bege cinza (arenoso ligeiramente argiloso)

$100-140 \mathrm{~cm}$ : gradualmente a matriz fica ligeiramente mais argilosa, com mais volumes avermelhados.

140 - $150 \mathrm{~cm}$ : aparecem volumes cinzas com água livre (matriz idem).

$150 \mathrm{~cm}$ : água livre.

160 - $200 \mathrm{~cm}$ : na matriz aparecem volumes argilosos mais secos com manchas avermelhadas endurecidas, matriz cinza.

$200-220 \mathrm{~cm}$ : manchas argilosas cinza com plintita (seco, oxidado) as manchas argilosas são reduzidas e volumes com água livre (matriz cinza).

$220 \mathrm{~cm}$ : nódulos, matriz cinza mais homogênea, mais úmido (saturado), diminui volumes avermelhados e cinzas.

220 - $270 \mathrm{~cm}$ : volta aumentar os volumes avermelhados, mais secos e com centros esverdeados. A partir dos $250 \mathrm{~cm}$ aparecem volumes verdes secos.

$270 \mathrm{~cm}$ : na ponta do trado camada verde entremeado no cinza e volumes avermelhados.

T4

0 - $30 \mathrm{~cm}$ : orgânico, marrom, arenoso.

$30-80 \mathrm{~cm}$ : areião branco com poucas manchas avermelhadas e também escuras.

$80-120 \mathrm{~cm}$ : na ponta do trado fica cinza, volumes avermelhados e bem endurecidos.

$120-130 \mathrm{~cm}$ : matriz cinza areno-argilosa, com volumes avermelhados secos.

130 - $240 \mathrm{~cm}$ : mais úmido, matriz cinza, com volumes de argila cinza claro (2,5Y6/1 e 6/2) e volumes avermelhados endurecidos

$240 \mathrm{~cm}$ : idem, nódulos (poucos), com volumes avermelhados.

$250 \mathrm{~cm}$ : laje (volumes verdes endurecidos), fragmentos.

T5

0 - $20 \mathrm{~cm}$ : orgânico marrom, seco, bem arenoso.

$20-110 \mathrm{~cm}$ : matriz bege claro (10YR 6/3), arenoso, com manchas avermelhadas.

$110-130 \mathrm{~cm}$ : matriz cinza com manchas difusas avermelhadas e escuras.

130 - $190 \mathrm{~cm}$ : cinza cor 5Y 5,4/2, com volumes esverdeados (5Y 5/3) e avermelhados endurecidos (5YR 5/8) e volumes argilosos cinza claro.

$150 \mathrm{~cm}$ : água livre.

$190 \mathrm{~cm}$ : encontrado a camada verde.

\section{T6}

0 - $30 \mathrm{~cm}$ : arenoso, com matéria orgânica, matriz marrom.

$30-50 \mathrm{~cm}$ : arenoso, bege claro.

50 - $90 \mathrm{~cm}$ : manchas avermelhadas mais nítidas difusas na matriz bege claro.

$90-100 \mathrm{~cm}$ : mudança abrupta do areno para areno-argiloso, matriz cinza com volumes avermelhados (do amarelo ao avermelhado).

$120 \mathrm{~cm}$ : idem com predomínio das manchas avermelhadas.

$130 \mathrm{~cm}$ : matriz cinza predomina mais, e bastante manchas avermelhadas. 
130 - $160 \mathrm{~cm}$ : volumes cinza claro argiloso com água no meio da matriz arenosa cinza, mais homogênea, com volumes verdes mais escuros e avermelhados (pouco).

$160 \mathrm{~cm}$ : água livre.

$160-120 \mathrm{~cm}$ : idem, com pequenos nódulos verde oliva.

$220 \mathrm{~cm}$ : somem as manchas avermelhadas. Matriz cinza com volumes de argila (cinza claro).

$230 \mathrm{~cm}$ : volta volumes avermelhados mais secos.

$250 \mathrm{~cm}$ : volumes mais esverdeados escuros (Gley 4/10Y) e de argila, matriz cinza mais homogênea.

\section{T7}

0 - $30 \mathrm{~cm}$ : arenoso orgânico, cor marrom.

$30-80 \mathrm{~cm}$ : arenoso bege claro com manchas amarelas difusas.

$80-120 \mathrm{~cm}$ : na ponta do trado manchas avermelhadas/ mudança abrupta do arenoso para o areno-argiloso (matriz cinza), com volumes de argila.

120 - $145 \mathrm{~cm}$ : bastante volumes avermelhados e de argila cinza claro, bem definidos (bem argiloso), predomina matriz cinza.

150 - $175 \mathrm{~cm}$ : matriz mais homogênea e pedaços de laje (fragmentos), com manchas (poucas) avermelhadas e de argila cinza claro.

$190 \mathrm{~cm}$ : aparece volumes esverdeados na matriz cinza

$200-210 \mathrm{~cm}$ : predomina volumes argilosos verdes.

$220 \mathrm{~cm}$ : camada verde.

T8

0 - $30 \mathrm{~cm}$ : camada orgânica (marrom escuro) arenoso.

30 - $40 \mathrm{~cm}$ : mudança abrupta para o bege claro com manchas (linhas) de matéria orgânica e avermelhadas.

$40-60 \mathrm{~cm}$ : volumes de MO mais argilosa (ligeiramente) dentro da matriz arenosa bege, tem areia lavada e volumes avermelhados argilosos

$60-70 \mathrm{~cm}$ : nódulos (idem) mais areia lavada

$70-80 \mathrm{~cm}$ : cor mais para o claro (areia lavada), areno-argiloso com MO.

80 - $100 \mathrm{~cm}$ : matriz cinza com bastante manchas nítidas amareladas com MO também, tem volumes mais argilosos.

100 - $115 \mathrm{~cm}$ : cor mosqueado - volumes cinza claro e avermelhados bem nítidos, bastante contraste, matriz cinza argilosa com areia muito fina, nódulos ferruginosos de 2 a $3 \mathrm{~mm}$.

115 - $130 \mathrm{~cm}$ : pouco contraste entre matriz cinza argiloso e as manchas e nódulos avermelhados.

130 - $140 \mathrm{~cm}$ matriz cinza argilosa com volumes amarelo - avermelhados bem nítidos (bem mais amarelo).

140 - $200 \mathrm{~cm}$ : matriz cinza mais claro (argiloso) e as manchas também mais clara indo para o branco, possui volumes amarelados. Na parte mais branca tem nódulos pequenos pouco friáveis, volumes avermelhados bem secos (plintita).

$200-210 \mathrm{~cm}$ : bolsões argilosos mais úmidos cinza claro, poucos volumes esverdeados amarelados, volumes amarelo avermelhados bem secos.

220 - $230 \mathrm{~cm}$ : na ponta do trado cinza esverdeado argiloso, e volumes esverdeados secos

230 - $250 \mathrm{~cm}$ : matriz cinza claro arenoso com volumes verdes com água livre.

T9

0 - $30 \mathrm{~cm}$ : orgânico bem marcado, bem escuro, arenoso.

$30-40 \mathrm{~cm}$ : um pouco mais claro, diminuem as manchas, mosqueado de matéria orgânica e vermelho

$45 \mathrm{~cm}$ : matriz mais clara ainda, com volumes mais escuros, igual volumes da trincheira

50 - $80 \mathrm{~cm}$ : já tem acumulações de $\mathrm{MO}$ dentro da areia - em cima da transição que passa

$80 \mathrm{~cm}$ : mais ou menos o final da acumulação da matéria orgânica, fica material mosqueado cinza marrom mais claro e vermelho.

90 - $100 \mathrm{~cm}$ : matriz cinza domina, ainda bem mosqueado, alguns nódulos de 2 a $3 \mathrm{~mm}$. Areno-argiloso. 
110 - $120 \mathrm{~cm}$ : cinza mais homogêneo, alguns volumes com água livre. Alguns volumes pretos pouco marcados, 1 a $2 \mathrm{~mm}$. Ainda areno-argiloso.

130 - $150 \mathrm{~cm}$ : manchas ocres muito bem marcadas, material muito mais argiloso, tipo plintita, menos úmido.

$160-200 \mathrm{~cm}$ : diminui a fase cinza escura mais argilosa. Parece ter material um pouco mais endurecido. Fase mais endurecida (pedaços endurecidos).

$200 \mathrm{~cm}$ : matriz mais arenosa, mais homogênea, ainda mais úmido.

$210 \mathrm{~cm}$ : na ponta do trado volumes esverdeados, material branco areno-argiloso.

$220 \mathrm{~cm}$ : material areno-argiloso, cinza claro com volumes esverdeados e avermelhados.

$230 \mathrm{~cm}$ : na ponta do trado material cinza claro com água livre, localmente, com volumes esverdeados e avermelhados. Alguns nódulos cimentados.

\section{T10}

$0-30 \mathrm{~cm}$ : arenoso marrom escuro.

$30-60 \mathrm{~cm}$ : bege claro, arenoso, manchas avermelhadas e de MO.

$60 \mathrm{~cm}$ : pouco menos de matéria orgânica e mais manchas avermelhadas.

70 - $75 \mathrm{~cm}$ : na ponta do trado volta a ficar pouco mais escuro (orgânico e manchas avermelhadas e mais escuras).

$75 \mathrm{~cm}$ : na ponta do trado matriz cinza, argilo-arenoso com pontos de plintita (pouco) e mais escuro de MO (úmido). Plintita bem degradado até $1.20 \mathrm{~m}$.

$120-200 \mathrm{~cm}$ : bem argiloso (Horizonte Plintitico H.P) com manchas amarelo avermelhadas bem secas (bem mais argiloso que o T8).

$200 \mathrm{~cm}$ : água livre em filetes (localizado) na matriz cinza bem claro, volumes avermelhados bem secos.

$220 \mathrm{~cm}$ : na ponta do trado aparece pontos de verde (mesma matriz) mais não chegou no verde. Não foi mais o trado, encontrado alguma coisa dura embaixo (camada endurecida) laje (nódulos duros) até 225 (já esfarelando, cinza bem seco). Embaixo da laje tem o lençol a $230 \mathrm{~cm}$, a partir disso volta a ser arenoso.

$240-270 \mathrm{~cm}$ : aparece manchas verdes mais arenoso (camada verde) até $295 \mathrm{~cm}$.

\section{T12}

0 - $30 \mathrm{~cm}$ : arenoso marrom escuro orgânico com pequenos volumes de areia lavada.

$30-80 \mathrm{~cm}$ : matriz bege claro arenosa com manchas de Fe e MO.

$80-105 \mathrm{~cm}$ : (franja do lençol) arenoso com MO na matriz cinza.

$105 \mathrm{~cm}$ : começa a ficar ligeiramente mais argiloso (matriz cinza) com manchas $\mathrm{MO}$ e avermelhadas.

120 - $160 \mathrm{~cm}$ : têm filetes de água e a textura não é tão argilosa, é areno-argilosa (pouco argila) tem mais areia. Matriz cinza com volumes avermelhados, mais ou menos secos.

$160 \mathrm{~cm}$ : água livre

$180 \mathrm{~cm}$ : encontra pequenos pontos de laje friável, pouco endurecido, textura areno-argilosa.

\section{CORES}

T8

170 - $190 \mathrm{~cm}$ - Cor variegada cinza - varia de $2.5 \mathrm{Y}$ 5/2 a 2.5Y 6/2 e 2.5Y 6/1 (mais claro) a $2.5 Y 7 / 1$ e o cinza mais escuro até $2.5 Y 4 / 3$

Cinza escuro avermelhado - 10YR 3/2,3; marrom amarelado - 10YR 3/6 (mais escuro), 10YR 4/6 - marrom amarelo avermelhado mais claro; Volumes mais avermelhados - $5 \mathrm{YR}$ $4 / 6$

130 - $160 \mathrm{~cm}$ - Amarelo mais vivo - 5Y 6/6; Cinza - 5Y 5/1

210 - $220 \mathrm{~cm}$ - Volumes esverdeados - 5Y 4/4 e 4/3; Volumes cinza mais escuro - 10YR 4/1; Volumes mais claros - 10YR 5/1 e 10YR 6/1

230 - 250 cm - Verde - Gley 4/10Y; Cinza amarelo esverdeado - 5Y 4/2; Cinza - Gley 5/10Y Com volumes esverdeados - Gley 4/10 GY; Pontos mais escuros do verde - Gley 3/5 GY

0 - 30 cm (camada orgânica) - 10YR 2/2 


\section{DEPRESSÃO FECHADA}

\section{G1 (cordilheira)}

$0-20 \mathrm{~cm}$ : arenoso; úmido 10YR 4,5/3 com poucos volumes escuros.

$20-30 \mathrm{~cm}$ : idem arenoso

$30-40 \mathrm{~cm}$ : idem com raiz de quaraguatá/arenoso.

$40-50 \mathrm{~cm}$ : com alguns volumes de areia mais clara /idem arenoso.

$50-60 \mathrm{~cm}$ : ponta trado 10YR5/3.

$60-100 \mathrm{~cm}$ : idem arenoso; 10YR5/3

$100-110$ - areia mais clara/ limite festonado, cor 10YR6/3

100 - 120 - idem

A partir de $120 \mathrm{~cm}$ : arenoso 10YR6,5/3

130 - $140 \mathrm{~cm}$ : entre 10YR7/2 e 7,5YR8/3

$150 \mathrm{~cm}$ : arenoso, matriz cor 7,5YR7/3 e linhas /horizontes cinza

$160 \mathrm{~cm}$ : idem cor e textura, ligeiramente cinza (que vem com água)

$190-200 \mathrm{~cm}$ : agua livre

$210-250 \mathrm{~cm}$ : na ponta do trado algumas manchas de ferrugem; muito difusas/rasas

250 - camada verde.

\section{G2 (limite com a grama)}

$0-50 \mathrm{~cm}: 10 \mathrm{YR} 5 / 3$ - arenoso (areia fina)

50 - $70 \mathrm{~cm}$ : matriz 10YR entre $6(5,5)$ e $5 / 3$ - arenoso com pequenas volumes de areia mais clara.

70 - $90 \mathrm{~cm}$ : na ponta do trado 6/3 (10YR6/3) arenoso com pequenas manchas e estrias mais escuras $7,5 \mathrm{YR} 6 / 3$

90 - $120 \mathrm{~cm}$ : cor mais clara 7,5YR7/3; arenoso.

120 - $150 \mathrm{~cm}$ : aparecem manchas amareladas dentro da matriz arenosa 7,5YR7/3, ligeiramente mais grossa.

150 - $200 \mathrm{~cm}$ : matriz cinza - água livre

200- $215 \mathrm{~cm}$ : na ponta trado - cinza esverdeado 10YR6/1.

\section{G3 (inicio Rabo de Burro)}

$0-60 \mathrm{~cm}$ : cor 7,5YR5/3 arenoso

$60-90 \mathrm{~cm}$ : fica mais claro 7,5YR6/3, ligeiramente mais úmido

90 - $115 \mathrm{~cm}$ : idem bem mais úmido 7,5YR6,5/3 com manchas escuras/estriadas.

115 - $120 \mathrm{~cm}$ : água livre - com poucas manhas amareladas

$135 \mathrm{~cm}$ : água livre

$150 \mathrm{~cm}$ : matriz arenosa; água livre e volume importante de MO/arenoso

$170 \mathrm{~cm}$ : volumes pretos e carvão (?)

$180 \mathrm{~cm}$ : na ponta do trado matriz cinza e final da ponta do trado acabou MO, arenoso, com manchas esverdeadas.

\section{G4 (final Rabo Burro)}

0 - $40 \mathrm{~cm}$ : cor $7,5 \mathrm{YR} 4,5 / 3$, arenoso a partir de $25 \mathrm{~cm}$ começa a ficar mais claro,

$40-70 \mathrm{~cm}$ : matriz 7,5YR5,5/3

70 - $90 \mathrm{~cm}$ : arenoso, mais claro, com manchas amarelas (10YR6/4)

$90 \mathrm{~cm}$ : desaparecem manchas amarelas

$100 \mathrm{~cm}$ : cor 10YR6/3 - na ponta do trado pequenos volumes avermelhados (10YR6/6)

$110 \mathrm{~cm}$ : na ponta do trado, volume escuro (MO) 10YR2/1

$120 \mathrm{~cm}$ : água livre - material preto se localiza no teto do lençol.

$150 \mathrm{~cm}$ : matriz cinza arenosa 5/10Y, volumes 5/5GY

$160 \mathrm{~cm}$ : material duro - deve ser a laje - fragmentos verdes.

\section{G5}

$0-30 \mathrm{~cm}$ : cor $10 \mathrm{YR} 3.5 / 2$, arenoso

$30 \mathrm{~cm}$ : fica mais claro $10 \mathrm{YR} 5 / 3$

$40 \mathrm{~cm}$ : bem mais claro10YR6/3 
$50 \mathrm{~cm}: 10 \mathrm{YR} 6,5 / 3$ arenoso

$60 \mathrm{~cm}$ : aparecem algumas manchas - 10YR7/3 (matriz), 7.5YR5/6 (manchas)

$70 \mathrm{~cm}$ : matriz arenosa/ nódulos endurecidos muito nítidos na matriz.

$80 \mathrm{~cm}$ : areia branca/ fim dos nódulos 7,5YR7/3

$90 \mathrm{~cm}$ : arenoso com manchas pequenas vermelhas/amareladas bem nítidas

$100 \mathrm{~cm}$ : matriz mais amarelada = muitas manchas amareladas - água livre.

$110 \mathrm{~cm}$ : ponta trado muda cor - impossível na tabela, muito molhado

$140 \mathrm{~cm}$ : água livre

$150 \mathrm{~cm}$ : na ponta do trado - matriz cinza 5/10Y quase verde - 5/5GY

G6 (centro da depressão)

0 - $30 \mathrm{~cm}: 10 \mathrm{YR} 4 / 3$ - arenoso

$30 \mathrm{~cm}$ : começo camada amarelada 10YR4,5/6, arenoso

$40 \mathrm{~cm}$ : cor 10YR5/6 - arenoso

$45 \mathrm{~cm}$ : presença de nódulos

$50 \mathrm{~cm}$ : matriz 10YR4,5/6, arenosa

$60 \mathrm{~cm}$ : na ponta do trado, final abrupto para a cor da matriz 10YR4,5/6 e arenoso mais claro 10YR6/2,3. O limite é marcado pela presença de nódulos (1 a $2 \mathrm{~cm}$ )

$60-100 \mathrm{~cm}$ : volta matriz arenosa bege com aumento umidade

$100 \mathrm{~cm}$ : água livre

$110-140 \mathrm{~cm}$ : matriz bege arenosa.

$145 \mathrm{~cm}$ : matriz cinza

$150 \mathrm{~cm}$ : camada verde - camada cinza/verde

\section{GA}

$0-40 \mathrm{~cm}$ : areia seca, arenosa, bege mais escuro

40 - $70 \mathrm{~cm}$ : mesma matriz com pequenos volumes de MO friáveis

$80 \mathrm{~cm}$ : matriz bege mais claro com manchas amareladas

$100 \mathrm{~cm}$ : idem com manchas de MO (poucas)

$110 \mathrm{~cm}$ : a textura da areia fica ligeiramente mais grossa (matriz bege claro)

$140 \mathrm{~cm}$ : areia mais úmida

$150 \mathrm{~cm}$ : água livre com cinza entremeado na matriz arenosa

$180 \mathrm{~cm}$ : predomínio da matriz cinza e tem areia entremeado

$190 \mathrm{~cm}$ : cinza predomina (argilo-arenoso) e tem tons de verde - cinza mais escuro (úmido)

$230 \mathrm{~cm}$ : cinza esverdeado

$240 \mathrm{~cm}$ : camada verde endurecida.

\section{GB}

$0-30 \mathrm{~cm}$ : areia seca

$30-50 \mathrm{~cm}$ : areia mais úmida

$50-60 \mathrm{~cm}$ : manchas avermelhadas difusas na areia

$60-80 \mathrm{~cm}$ : aumentam manchas avermelhadas

$80-100 \mathrm{~cm}$ : volumes avermelhados e pretos - bandas ferrugem de $1 \mathrm{~mm}$

$100-150 \mathrm{~cm}$ : areia mais clara, mais úmida. Desaparecem manchas avermelhadas e pretas

150 - $160 \mathrm{~cm}$ : abruptamente, na matriz cinza, aparecem volumes argilosos cinza claro. Em torno do cinza uma auréola amarela avermelhada difusa

$160-170 \mathrm{~cm}$ : material cinza um pouco mais argiloso

$175 \mathrm{~cm}$ : idem com mais manchas avermelhadas

$180 \mathrm{~cm}$ : volumes verdes na ponta do trado

$190 \mathrm{~cm}$ : camada verde 


\section{ANEXO 2}

Gráficos das análises de Raio-X nas amostras de solos das sequências estudadas 

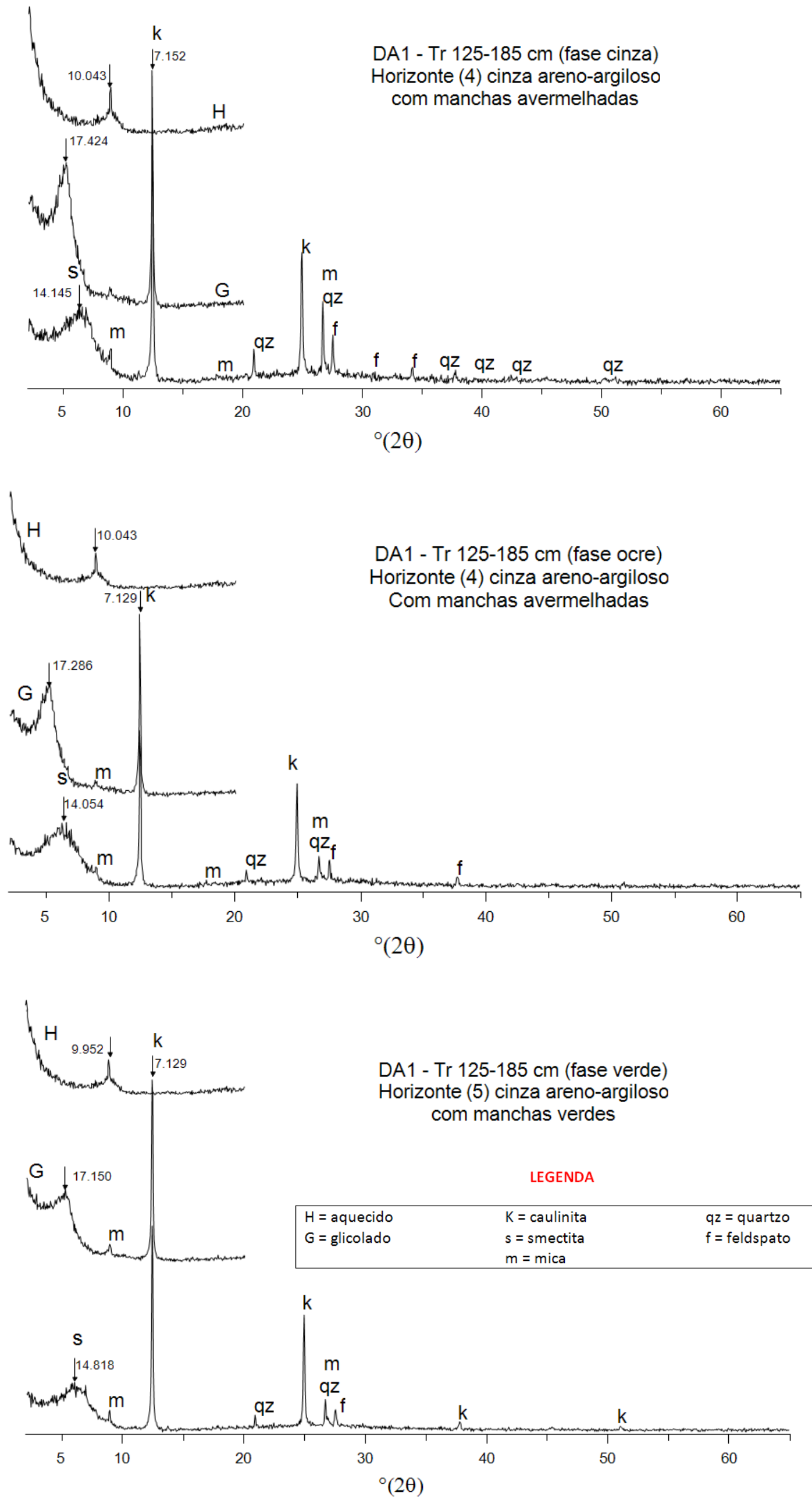

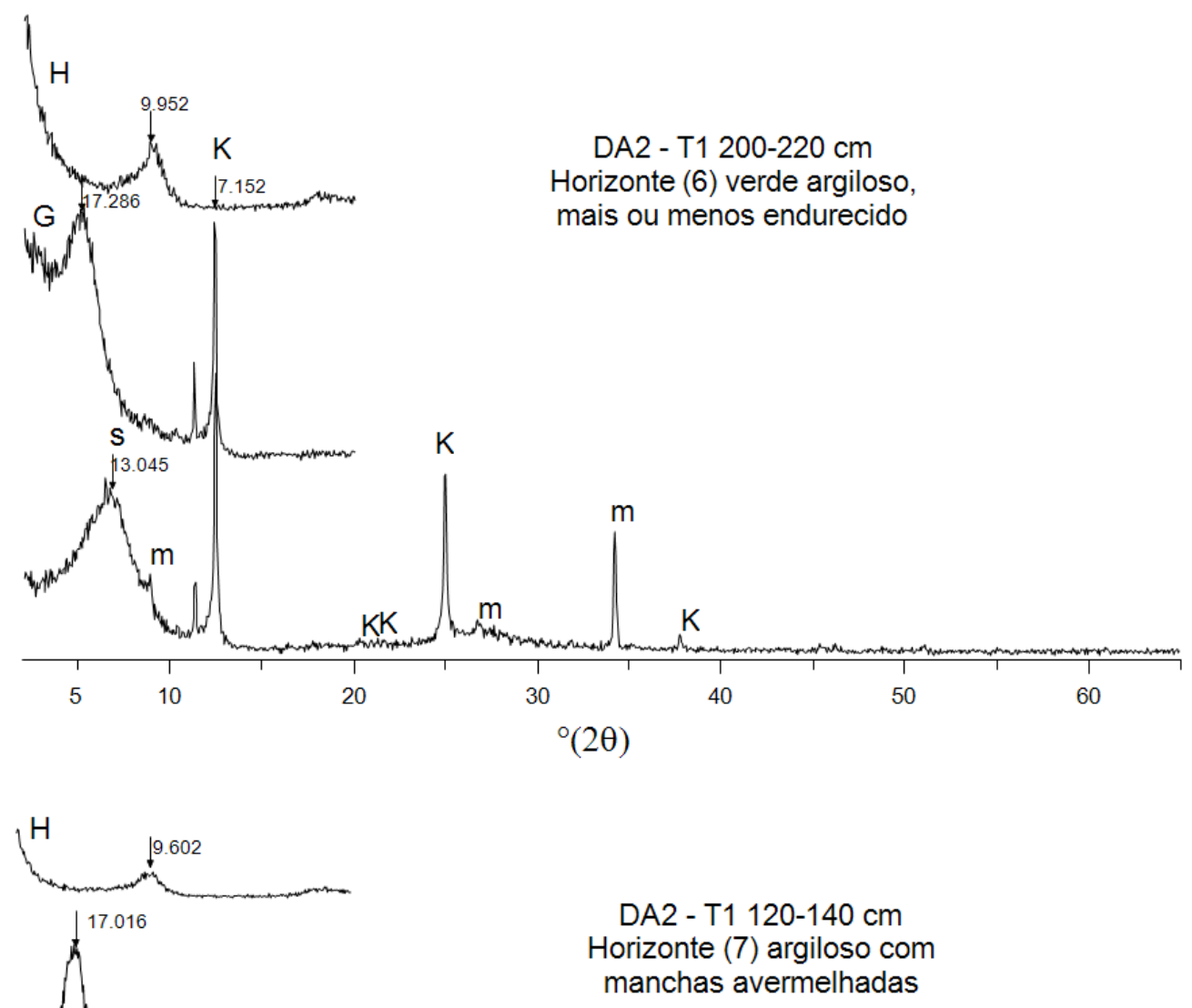

Horizonte (7) argiloso com

G

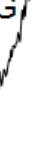

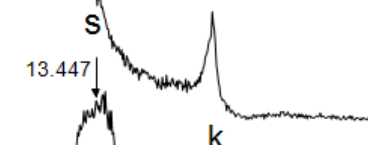

k

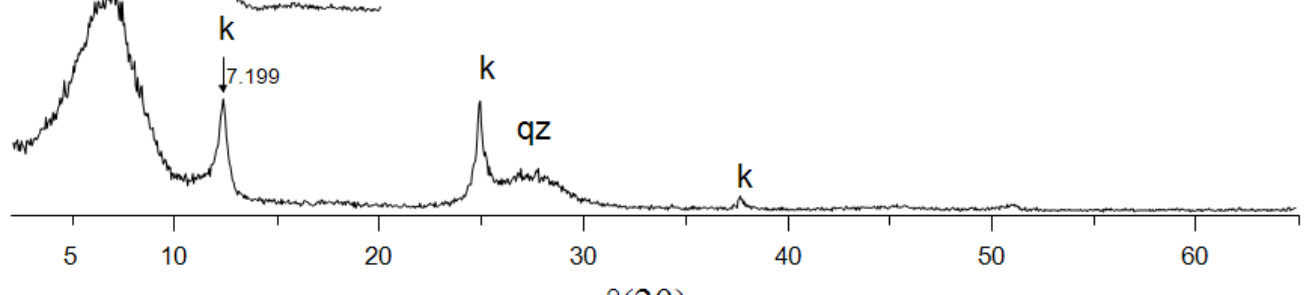

${ }^{\circ}(2 \theta)$

k

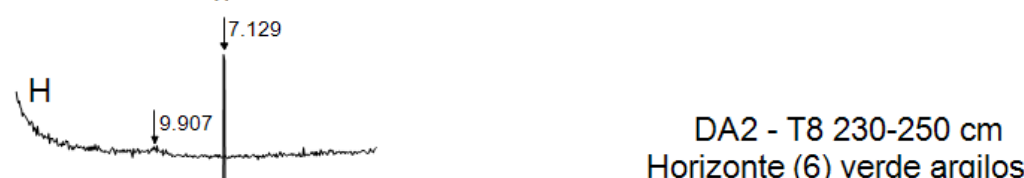

Horizonte (6) verde argiloso,

mais ou menos endurecido
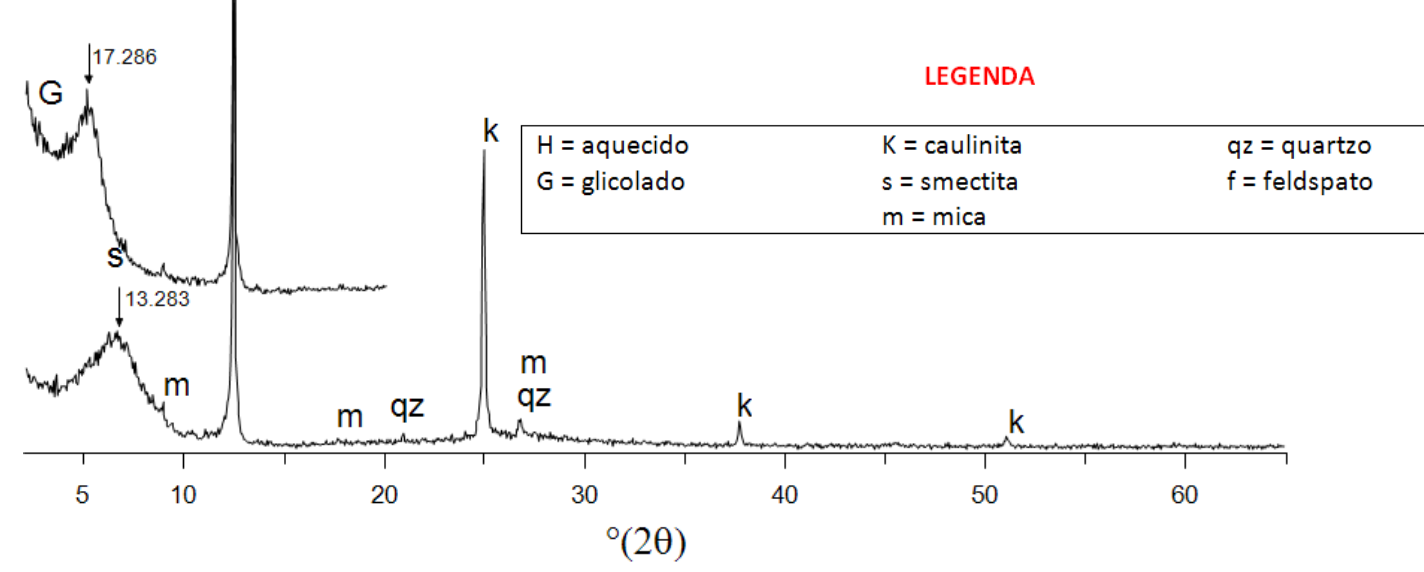

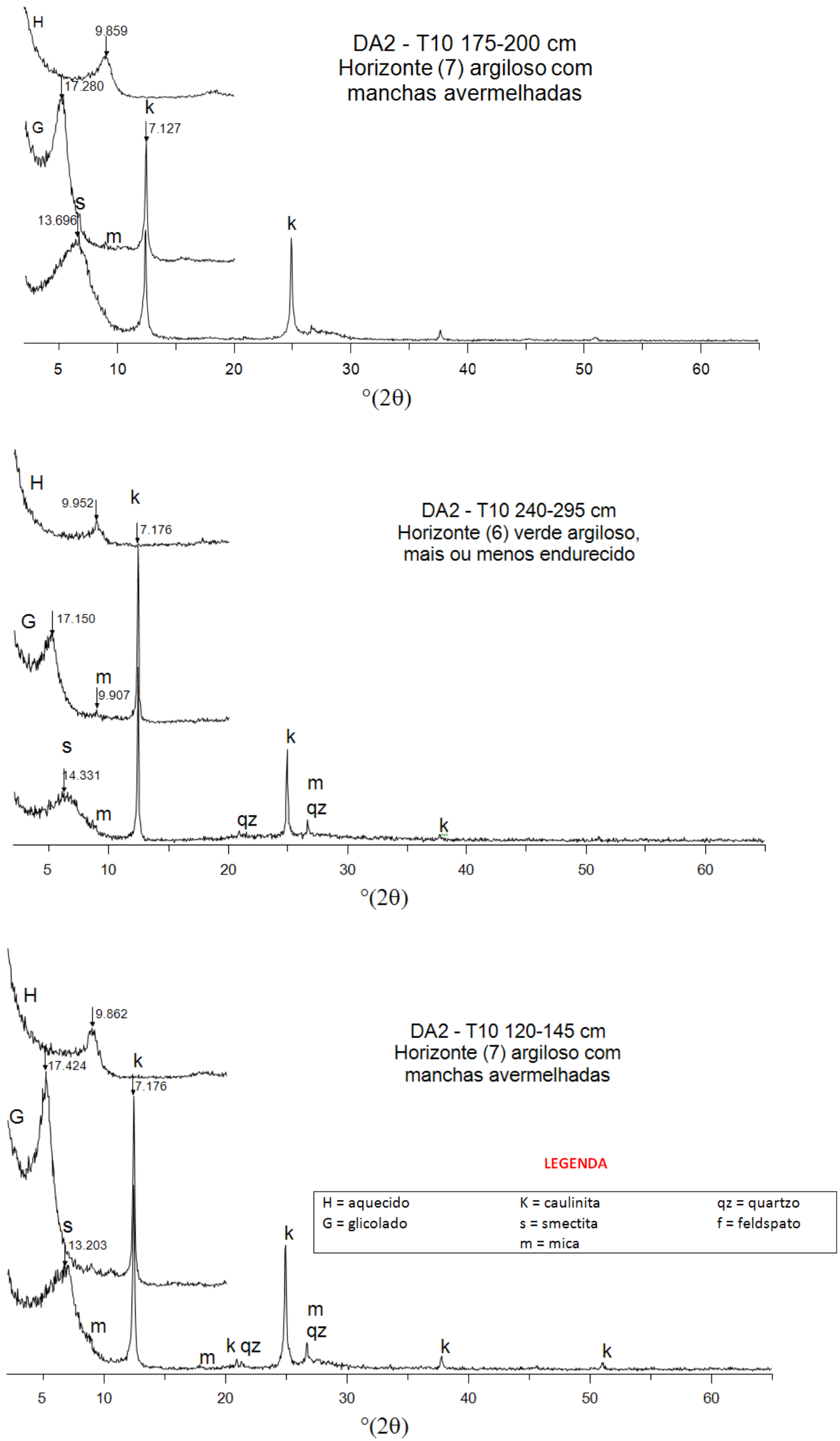

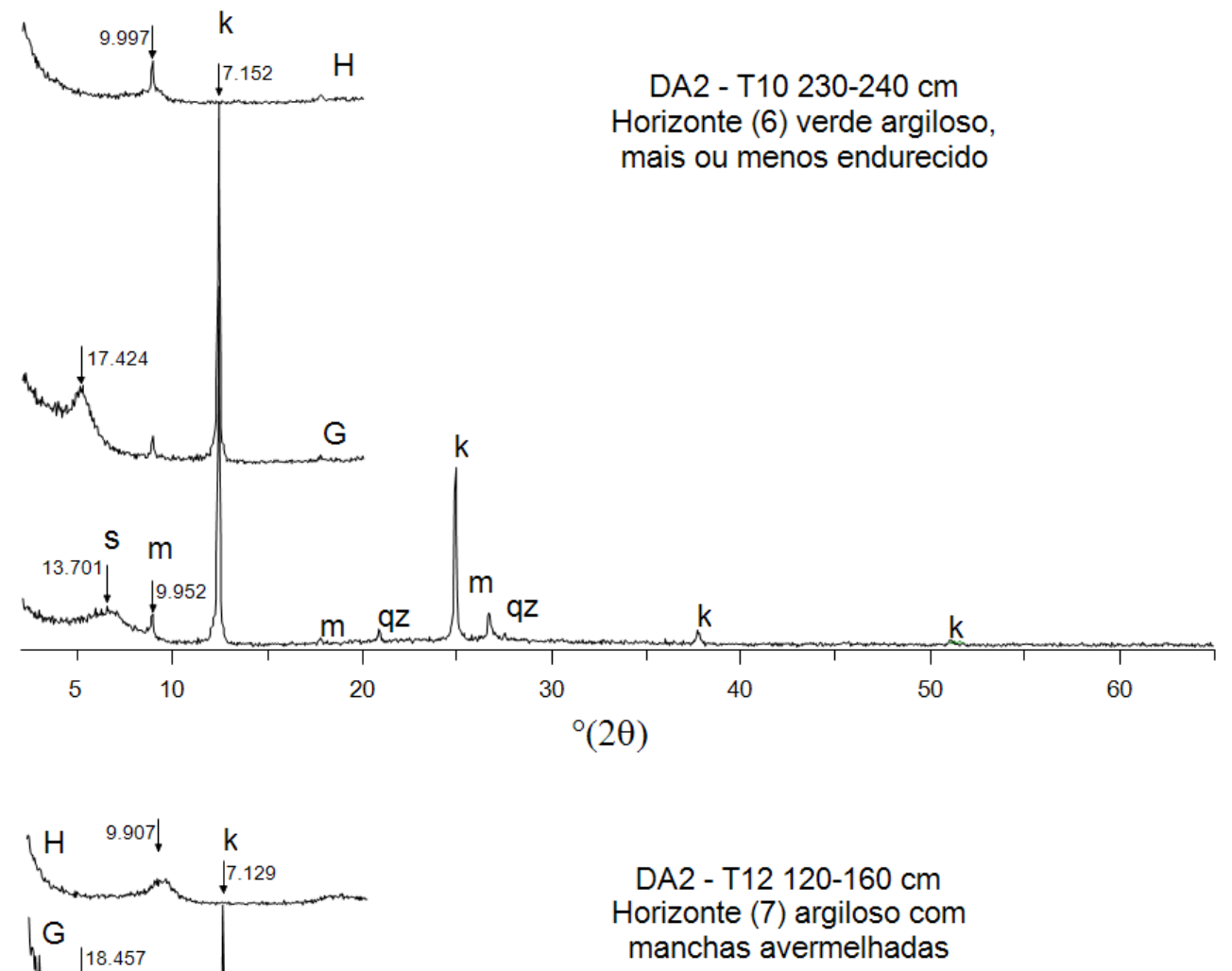

Horizonte (7) argiloso com

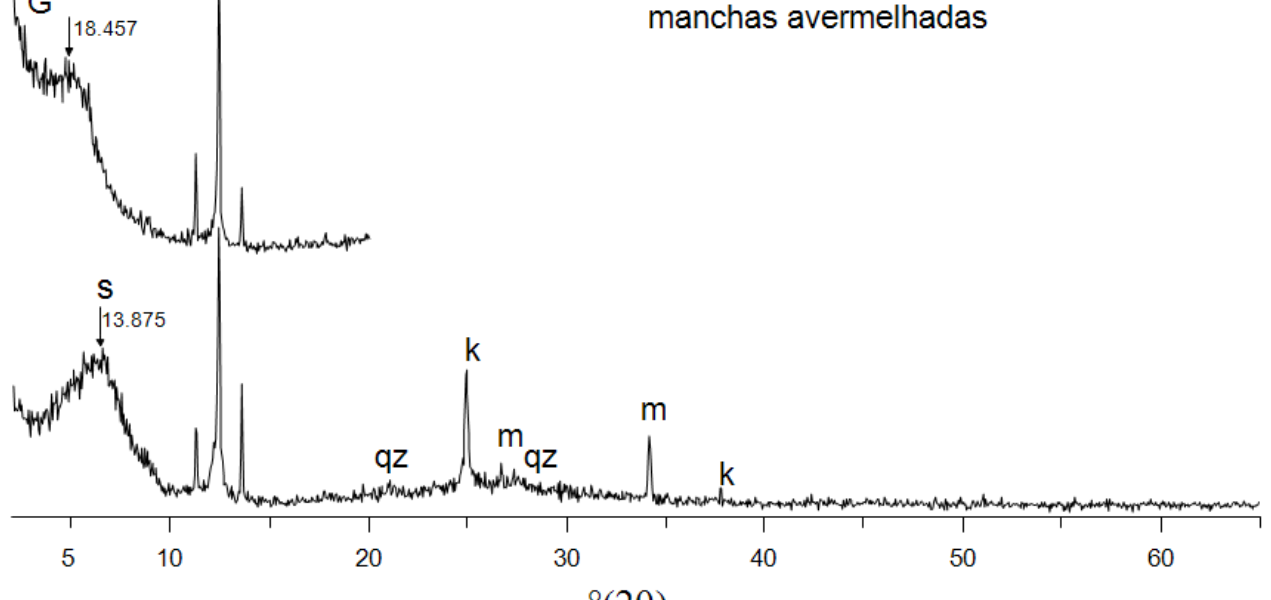

${ }^{\circ}(2 \theta)$
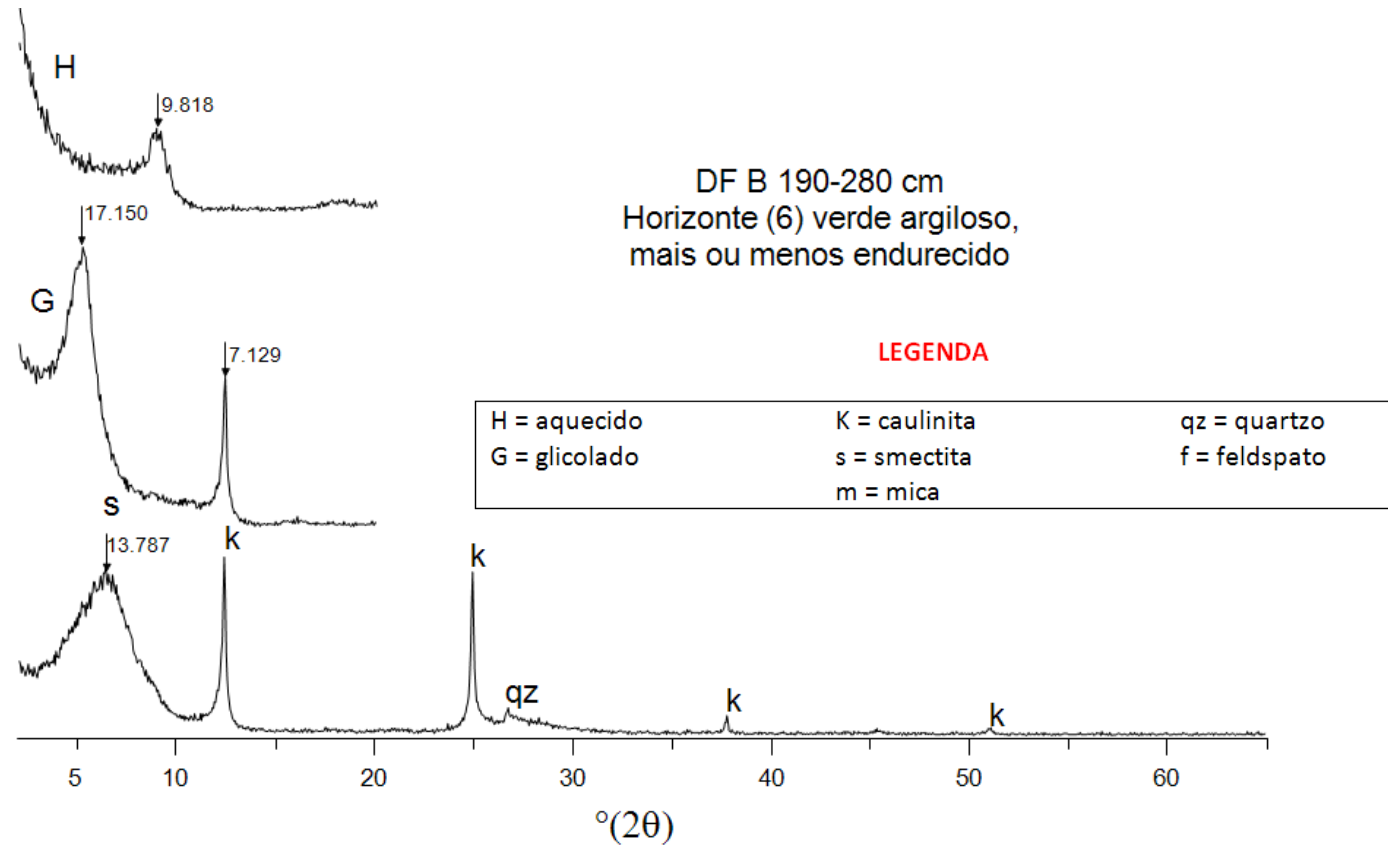